\title{
Ready Approach to Organophosphines from ArCl via Selective Cleavage of C-P Bonds by Sodium
}

Jingjing Ye, ,ab Jian-Qiu Zhang, ${ }^{\text {a,b }}$ Yuta Saga, ${ }^{\mathrm{c}}$ Shun-ya Onozawa, ${ }^{\mathrm{a}}$ Shu Kobayashi, ${ }^{a}$ Kazuhiko Sato,a Norihisa Fukaya, ${ }^{a}$ Li-Biao Han ${ }^{\text {ab* }}$.

a,bNational Institute of Advanced Industrial Science and Technology (AIST), Tsukuba, Ibaraki 305-8565, Japan bDivision of Chemistry, Faculty of Pure and Applied Sciences, University of Tsukuba, Tsukuba, Ibaraki 305-8571, Japan

'New Products Development Laboratory, Maruzen Petrochemical Co., Ltd., Ichihara-shi, Chiba 290-8503, Japan

${ }^{\mathrm{d} D e p a r t m e n t ~ o f ~ C h e m i s t r y, ~ G r a d u a t e ~ S c h o o l ~ o f ~ S c i e n c e, ~ T h e ~ U n i v e r s i t y ~ o f ~ T o k y o, ~ B u n k y o-k u, ~ T o k y o ~ 113-0033, ~ J a p a n ~}$

\section{List of Contents}

Part 1. Preparation of $R^{1} R^{2} P N a$ from $R^{1} R^{2} P C l$ and $P h_{2} P O R$ using SD...................................

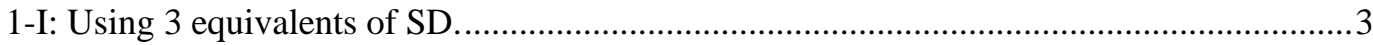

1-II: Using 0.2, 0.5, and 1 equivalents of SD................................................................

Part 2. Preparation of $R^{1} R^{2} P N a$ from $R^{1} R^{2} P P h$ and SD. ...................................................7

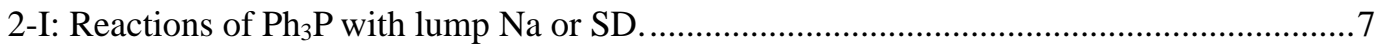

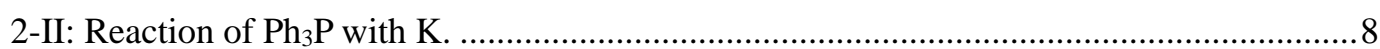

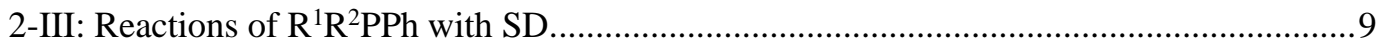

Part 3. Reactions of $\mathrm{Ph}_{2} \mathrm{PNa}$ with ArX............................................................................................14

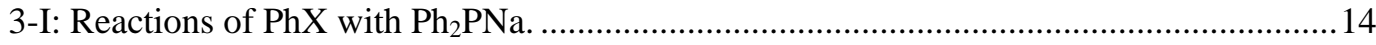

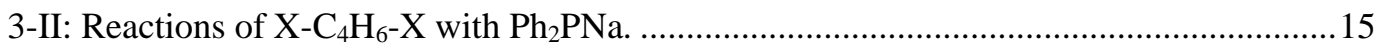

Part 4. Reactions of $\mathrm{Ph}_{2} \mathrm{PM}$ with aryl chlorides. ...................................................................18

Part 5. Preparation of $\mathrm{Ph}_{2} \mathrm{PR}$ from $\mathrm{Ph}_{2} \mathrm{PNa}$ and $\mathrm{RCl}$....................................................................20

Part 6. Reactions of $\mathrm{Ph}_{2} \mathrm{PNa}$ with tert-alkyl halides.................................................................23

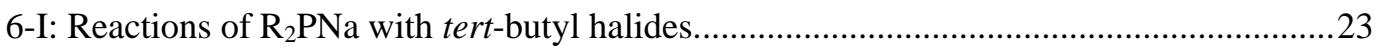

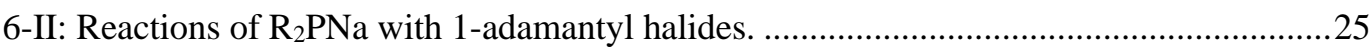

Part 7. The preparation of $R^{1} R^{2} P A r$ from $R^{1} R^{2} P N a$ and aryl halides......................................27

Part 8. One-pot synthesis of an unsymmetric phosphine...................................................................28

Part 9. Synthesis of chiral phosphine using sodium phosphides.....................................................30

Part 10. List of spectra data of the products.....................................................................33

Part 11. Copies of ${ }^{1} \mathrm{H},{ }^{31} \mathrm{P}$ and ${ }^{13} \mathrm{C}$ NMR spectra. ............................................................................46 


\section{General information:}

All reactions were carried out in the oven-dried Schlenk tubes or NMR tubes under nitrogen or argon atmosphere. All solvents were purchased and used without further purification. SD (sodium fine dispersed in paraffin oil with $\mu \mathrm{m}$-scale sizes with a concentration of $10 \mathrm{~mol} / \mathrm{L}$ ) was provided by Kobelco Eco-Solutions Co., Ltd. ${ }^{1} \mathrm{H}$ NMR spectra were recorded on JEOL JNM-ECS400 (400 MHz) FT NMR in $\mathrm{CDCl}_{3}$ with $\mathrm{Me}_{4} \mathrm{Si}$ as an internal standard. ${ }^{13} \mathrm{C}$ NMR spectra were taken on JEOL JNM-ECS400 (100 MHz) FT NMR system in $\mathrm{CDCl}_{3} .{ }^{31} \mathrm{P}$ NMR spectra were taken on JEOL JNM-ECX400 (162 MHz) FT NMR system in $\mathrm{CDCl}_{3}$ with 85\% $\mathrm{H}_{3} \mathrm{PO}_{4}$ solution as an external standard. Mass spectra were measured on a Shimadzu GCMS-QP2010 plus spectrometer (EI). Preparative HPLC isolation was performed using JAPAN ANALYTICAL INDUSTRY LC-908 equipped with two columns JAIGEL-1H (a polystyrene-based GPC column). The high resolution ESI mass spectra were recorded on Bruker microTOF II.

\section{Caution!}

Although declared safer than lump sodium, still SD (metallic sodium finely dispersed in paraffin oil with $\mu m$-scale sizes) is a dangerous chemical that must be handled carefully. SD can react vigorously with water, alcohols etc to produce hydrogen gas.

SD is commercially available, can be purchased from TCI etc. For its SDS, see https://www.tcichemicals.com/JP/ja/p/D5792 (SD). 


\section{Part 1. Preparation of $R^{1} R^{2} P N a$ from $R^{1} R^{2} P C l$ and $P h_{2} P O R$ using SD.}

\section{1-I: Using 3 equivalents of SD.}

Table S1: Generation of $\mathrm{R}^{1} \mathrm{R}^{2} \mathrm{PNa}$ from $\mathrm{R}^{1} \mathrm{R}^{2} \mathrm{PZ}(\mathrm{Z}=\mathrm{Cl}$ or $\mathrm{OR})$ and SD.

\begin{tabular}{ccc} 
& $\mathrm{R}^{1} \mathrm{R}^{2} \mathrm{PZ}$ & \multicolumn{2}{c}{$\mathrm{TD}$} & $\mathrm{R}^{1} \mathrm{R}^{2} \mathrm{PNa}, 2{ }^{\circ} \mathrm{C}$ & $\begin{array}{r}\text { quantitative } \\
\text { qun }\end{array}$ & $\mathrm{R}^{1} \mathrm{R}^{2} \mathrm{PG}$ & $\mathrm{R}^{1} \mathrm{R}^{2} \mathrm{PNa}^{a}$ \\
\hline 1 & $\mathrm{Ph}_{2} \mathrm{PCl}$ & $\mathrm{Ph}_{2} \mathrm{PNa}$ \\
$2^{b}$ & $n-\mathrm{Bu}_{2} \mathrm{PCl}$ & $n-\mathrm{Bu}_{2} \mathrm{PNa}$ \\
$3^{b}$ & $(-)-\mathrm{MenPhPCl}$ & $(-)-\mathrm{MenPhPNa}$ \\
4 & $\mathrm{Ph}_{2} \mathrm{POPh}$ & $\mathrm{Ph}_{2} \mathrm{PNa}$ \\
5 & $\mathrm{Ph}_{2} \mathrm{POEt}$ & $\mathrm{Ph}_{2} \mathrm{PNa}$ \\
\hline
\end{tabular}

${ }^{a} \mathrm{~A}$ mixture of $3.0 \mathrm{mmol}$ of SD and $1.0 \mathrm{mmol} \mathbf{1}$ dissolved in $2.0 \mathrm{~mL}$ THF was stirred in a sealed tube at room temperature for $1 \mathrm{~h}$ under nitrogen. Yields were determined by ${ }^{31} \mathrm{P}$ NMR based on 1 used. ${ }^{b} 67^{\circ} \mathrm{C}, 16 \mathrm{~h} .{ }^{c} 67^{\circ} \mathrm{C}, 24$ $\mathrm{h}$

run 1: Under nitrogen, $1.0 \mathrm{mmol} \mathrm{Ph}_{2} \mathrm{PCl}(90 \mu \mathrm{L})$ was dissolved in $2.0 \mathrm{~mL}$ THF, and then 3.0 mmol SD $(0.3 \mathrm{~mL}, 10 \mathrm{~mol} / \mathrm{L})$ was added dropwise at room temperature. After 1 hour, the reaction mixture was analyzed using ${ }^{31} \mathrm{P}$ NMR spectroscopy. $\mathrm{Ph}_{2} \mathrm{PNa}, \delta=-23.39$ ( $>99 \%$ purity).

Figure S1: ${ }^{31} \mathrm{P}-\mathrm{NMR}$ spectrum of $\mathrm{Ph}_{2} \mathrm{PNa}$

run 2: Under nitrogen, to the solution of $n-\mathrm{Bu}_{2} \mathrm{PCl}(1.0 \mathrm{~mL}, 1.0 \mathrm{mmol}, 0.5 \mathrm{~mol} / \mathrm{L}$ in tetrahydrofuran), SD ( $0.3 \mathrm{~mL}, 3 \mathrm{mmol}, 10 \mathrm{~mol} / \mathrm{L})$ was added at room temperature. After 16 hours, the reaction mixture was analyzed using ${ }^{31} \mathrm{P}$ NMR. $\delta=-72.38\left(n-\mathrm{Bu}_{2} \mathrm{PH}, 16 \%\right),-68.65$ (n-Bu $\left.{ }_{2} \mathrm{PNa}, 23 \%\right),-41.87\left(\left(n-\mathrm{Bu}_{2} \mathrm{P}\right)_{2}, 39 \%\right)$.

Preparation of $\boldsymbol{n}-\mathbf{B u}_{2} P \mathrm{PNa}$ : Step 1, preparation of $\mathrm{Bu}_{2} \mathrm{PCl}$ : to an oven-dried glass tube containing a Teflon-coated stirring bar was charged with $5.0 \mathrm{mmol} n-\mathrm{Bu}_{2} \mathrm{P}(\mathrm{O}) \mathrm{H}(0.81 \mathrm{~g})$ under nitrogen. The tube was cooled with ice-water and $50 \mathrm{mmol} \mathrm{PCl}_{3}(4.3 \mathrm{~mL})$ was added and stirred for 5 minutes. 
The volatiles were removed in vacuo to get analytically pure $n-\mathrm{Bu}_{2} \mathrm{PCl}$ as confirmed by ${ }^{31} \mathrm{P} \mathrm{NMR}$ spectroscopy $\delta=114.79$ (> 99\% purity). Step 2, $n$ - $\mathrm{Bu}_{2} \mathrm{PCl}$ was dissolved in $10 \mathrm{~mL}$ THF and SD (1.5 mL, $15 \mathrm{mmol}, 10 \mathrm{~mol} / \mathrm{L})$ was added at room temperature, and then heated at $67{ }^{\circ} \mathrm{C}$ for 16 hours. Solids were removed from the solution by centrifugation. Sodium dibutylphosphide $\left(n-\mathrm{Bu}_{2} \mathrm{PNa}\right)$ in THF was a light-yellow solution. $\delta=-68.78$ (> 99\% purity).

Figure S2: ${ }^{31} \mathrm{P}-\mathrm{NMR}$ spectrum of $\mathrm{n}-\mathrm{Bu} \mathrm{u}_{2} \mathrm{PCl} . \quad$ Figure S3: $\mathrm{n}-\mathrm{Bu} \mathrm{u}_{2} \mathrm{PCl}$ reacted with $\mathrm{SD}$ at r.t.
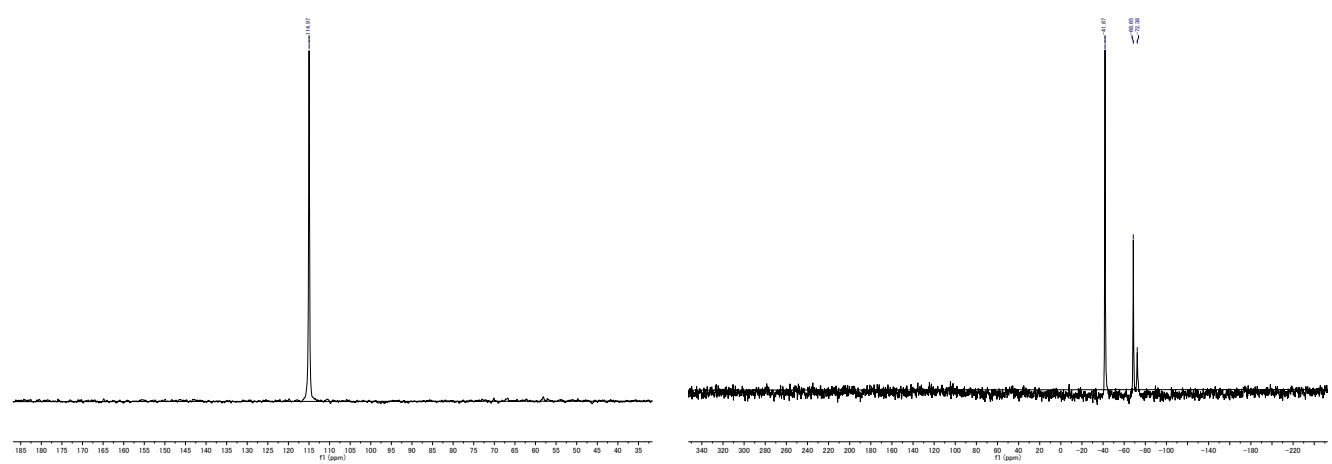

Figure S4: $\mathrm{n}-\mathrm{Bu} \mathrm{u}_{2} \mathrm{PCl}$ reacted with $\mathrm{SDat} 67^{\circ} \mathrm{C}$

in $\mathrm{THF}$ giving high pure $\mathrm{n}-\mathrm{Bu}_{2} \mathrm{PNa}$.

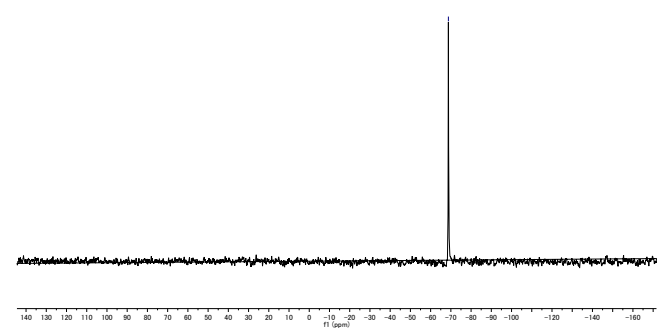

run 3 (the formation of 2c): Step 1, preparation of (-)-MenPhPCl: an oven-dried glass tube containing a Teflon-coated stir bar was charged with (-)-MenPhP(O)H (0.66 g, diastereomer mixture (47:53), $2.5 \mathrm{mmol})$ and THF (5 mL) under nitrogen. The glass tube was cooled with ice-water and $\mathrm{PCl}_{3}(0.81 \mathrm{~mL}, 10 \mathrm{mmol})$ was added and the solution was stirred for 1 hour. After removal of the volatiles in vacuo, (-)-MenPhPCl was obtained as a mixture of diastereomers as confirmed by ${ }^{31} \mathrm{P}$ NMR spectroscopy: $\delta=106.10$ (70\%), 101.08 (30\%). Step 2, (-)-MenPhPCl thus obtained was dissolved in $5 \mathrm{~mL}$ THF and SD $(0.5 \mathrm{~mL}, 5 \mathrm{mmol}, 10 \mathrm{~mol} / \mathrm{L})$ was added at room temperature. After stirring at $67^{\circ} \mathrm{C}$ for 24 hours, the solids were removed by centrifugation to get sodium (-)-menthyl phenylphosphide ((-)-MenPhPNa) in THF as an orange transparent solution. ${ }^{31} \mathrm{P}$ NMR spectroscopy $\delta=-25.38$ (purity 98\%). 

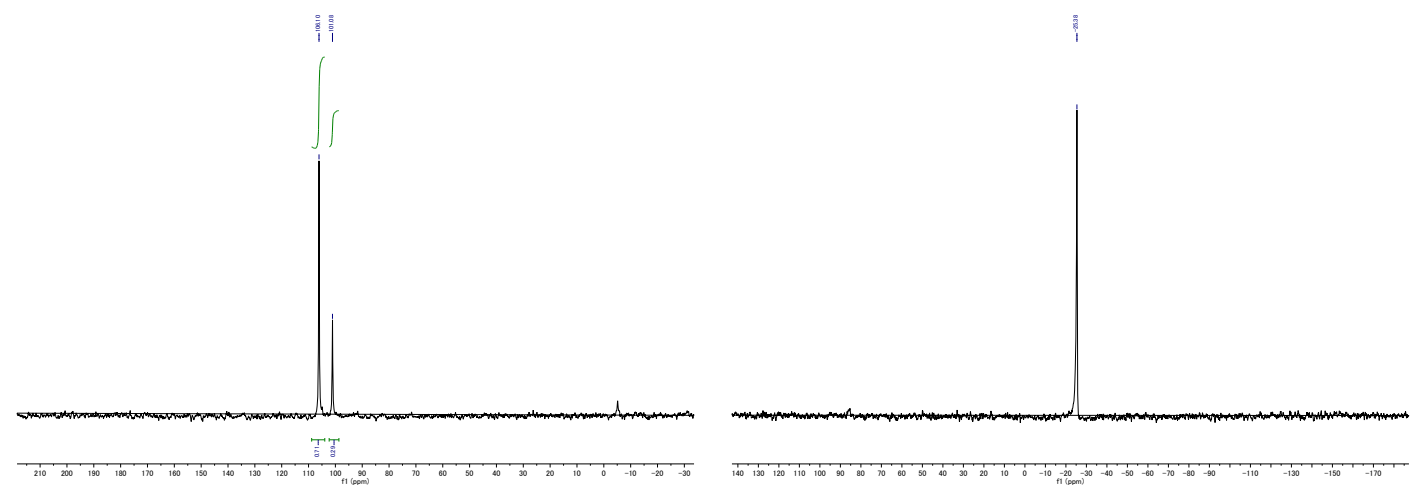

run 4: Under nitrogen, $1.0 \mathrm{mmol} \mathrm{Ph}_{2} \mathrm{POPh}(0.28 \mathrm{~g})$ was dissolved in $2 \mathrm{~mL} \mathrm{THF}$, and then 3.0 $\mathrm{mmol} \mathrm{SD}(0.3 \mathrm{~mL}, 10 \mathrm{~mol} / \mathrm{L})$ was added at room temperature. After 1 hour, the reaction mixture was analyzed by ${ }^{31} \mathrm{P}$ NMR spectroscopy showing that $\mathrm{Ph}_{2} \mathrm{PNa}$ was generated in a high yield, $\delta=$ -22.02 (98\% purity).

Figure S7: ${ }^{31} \mathrm{P}-\mathrm{NMR}$ spectrum of the $\mathrm{Ph}_{2} \mathrm{PNa}$ solution

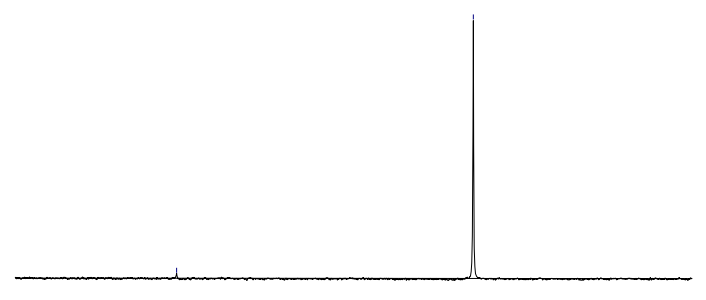

run 5: Under nitrogen atmosphere, $1.0 \mathrm{mmol} \mathrm{Ph}_{2} \mathrm{POEt}(0.1 \mathrm{~mL})$ was dissolved in $2 \mathrm{~mL} \mathrm{THF}$, and then $3.0 \mathrm{mmol} \mathrm{SD}(0.3 \mathrm{~mL}, 10 \mathrm{~mol} / \mathrm{L})$ was added at room temperature. After 1 hour, the reaction mixture was analyzed using ${ }^{31} \mathrm{P}$ NMR spectroscopy showing that $\mathrm{Ph}_{2} \mathrm{PNa}$ was generated in a high yield $\delta=-22.79$ (98\% purity).

Figure S8: ${ }^{31} \mathrm{P}-\mathrm{NMR}$ spectrum of $\mathrm{Ph}_{2} \mathrm{PNa}$ generated

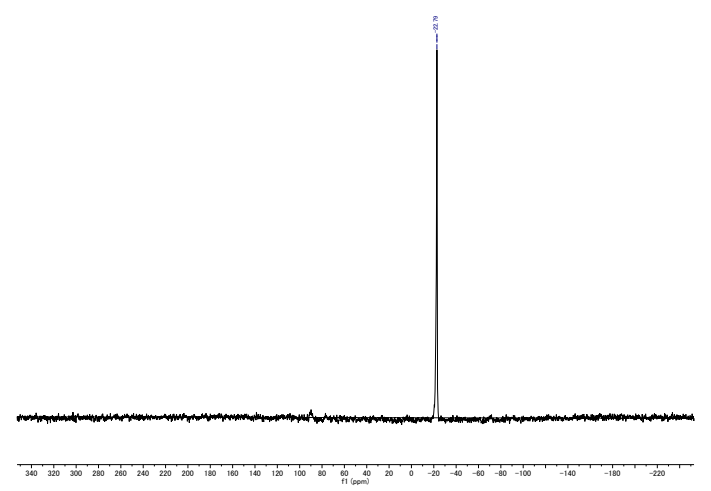

1-II: Using 0.2, 0.5, and 1 equivalents of SD. 
Figure S9.

$$
\begin{aligned}
& \mathrm{Ph}_{2} \mathrm{PZ} \underset{\mathrm{THF}, 25{ }^{\circ} \mathrm{C}}{\stackrel{\mathrm{SD}}{\longrightarrow}}\left(\mathrm{Ph}_{2} \mathrm{P}\right)_{2} \\
& (\mathrm{Z}=\mathrm{Cl} \text {, OPh, OEt })
\end{aligned}
$$

0.2 equiv. SD ( $0.05 \mathrm{~mL}, 0.5 \mathrm{mmol}, 10 \mathrm{~mol} / \mathrm{L})$ was added to $\mathrm{Ph}_{2} \mathrm{PCl}(90 \mu \mathrm{L}, 1 \mathrm{mmol})$ in $2 \mathrm{~mL}$ THF at room temperature. The mixture was analyzed by ${ }^{31} \mathrm{P} \mathrm{NMR}$, and the ratio of $\mathrm{Ph}_{2} \mathrm{PCl}(\delta=82.87$ ppm) vs $\left(\mathrm{Ph}_{2} \mathrm{P}\right)_{2}(\delta=-14.83 \mathrm{ppm})$ was $60 / 31$.

Figure S10: ${ }^{31} \mathrm{P}-\mathrm{NMR}$ spectrum for $\mathrm{Ph}_{2} \mathrm{PCl}+0.2$ equiv $\mathrm{SD}$

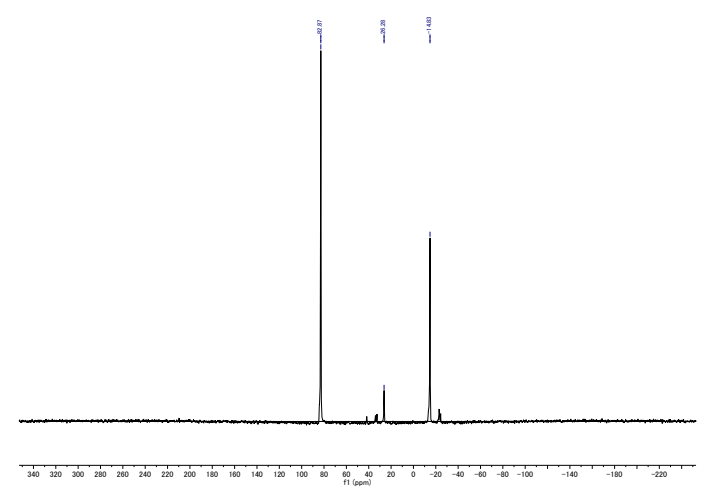

Similarly, $\mathrm{Ph}_{2} \mathrm{POPh}(0.28 \mathrm{~g}, 1 \mathrm{mmol})$ reacted with $\mathrm{SD}(0.05 \mathrm{~mL}, 0.5 \mathrm{mmol}, 10 \mathrm{~mol} / \mathrm{L})$. The ratio of $\mathrm{Ph}_{2} \mathrm{POPh}(\delta=110.91 \mathrm{ppm})$ vs $\left(\mathrm{Ph}_{2} \mathrm{P}\right)_{2}(\delta=-14.87 \mathrm{ppm})$ was $62 / 38$.

Figure S11: ${ }^{31} \mathrm{P}-\mathrm{NMR}$ spectrum for $\mathrm{Ph}_{2} \mathrm{POPh}+0.2$ equiv $\mathrm{SD}$

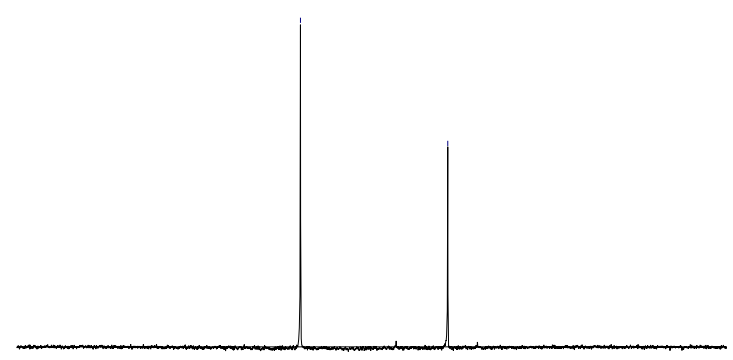

SD 0.5 equiv ( $0.05 \mathrm{~mL}, 0.5 \mathrm{mmol})$ was added to $\mathrm{Ph}_{2} \mathrm{POEt}(0.1 \mathrm{~mL}, 1 \mathrm{mmol})$ in $2 \mathrm{~mL}$ THF at room temperature. After 0.5 hour, ${ }^{31} \mathrm{P}$ NMR showed that the ratio of $\left(\mathrm{Ph}_{2} \mathrm{P}\right)_{2}$ vs $\mathrm{Ph}_{2} \mathrm{POEt}$ was $62 / 37$. On the other hand, when 1.0 equiv. SD was used, after 0.5 hour, ${ }^{31} \mathrm{P}$ NMR showed $\left(\mathrm{Ph}_{2} \mathrm{P}\right)_{2}$ was generated exclusively ( $\delta=-14.79$, 99\% purity). 
Figure S12: ${ }^{31} \mathrm{P}-\mathrm{NMR}$ spectrum of $\mathrm{Ph}_{2} \mathrm{POEt}$ Figure S13: ${ }^{31} \mathrm{P}$-NMR spectrum of $\mathrm{Ph}_{2} \mathrm{POEt}$

+0.2 equiv $S D$

+1 equiv $S D$
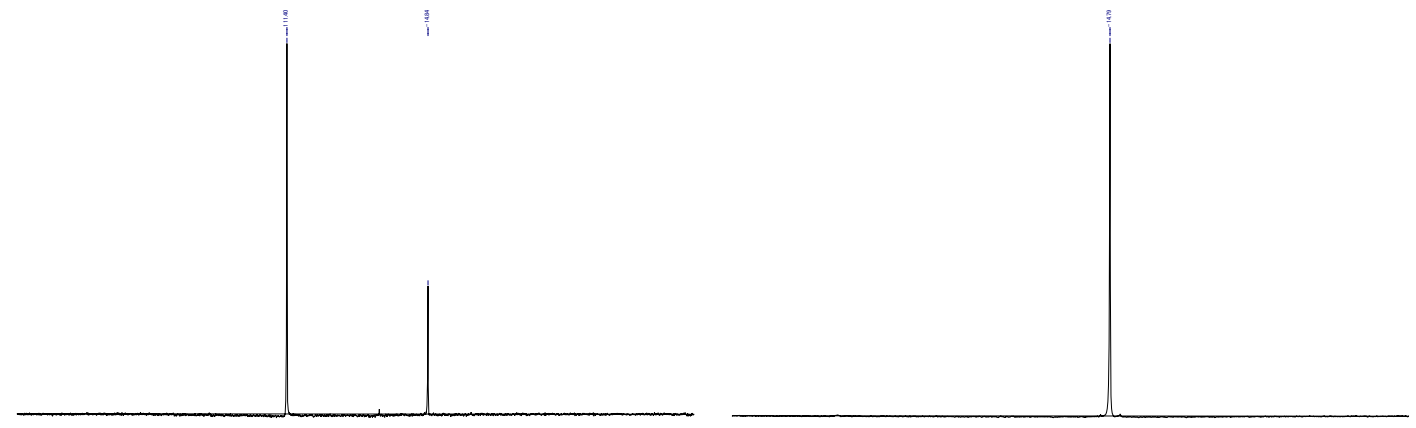

\section{Part 2. Preparation of $\mathbf{R}^{1} \mathbf{R}^{2} \mathbf{P N a}$ from $\mathbf{R}^{1} \mathbf{R}^{2} \mathbf{P P h}$ and $\mathrm{SD}$.}

\section{2-I: Reactions of $\mathrm{Ph}_{3} \mathrm{P}$ with lump Na or SD.}

Figure S14: ${ }^{31} \mathrm{P}$ NMR spectroscopies of $\mathrm{Ph}_{2} \mathrm{PNa}$ generated from $\mathrm{Ph}_{3} \mathrm{P}$ using lump $\mathrm{Na}$ (up) and SD (down), respectively.
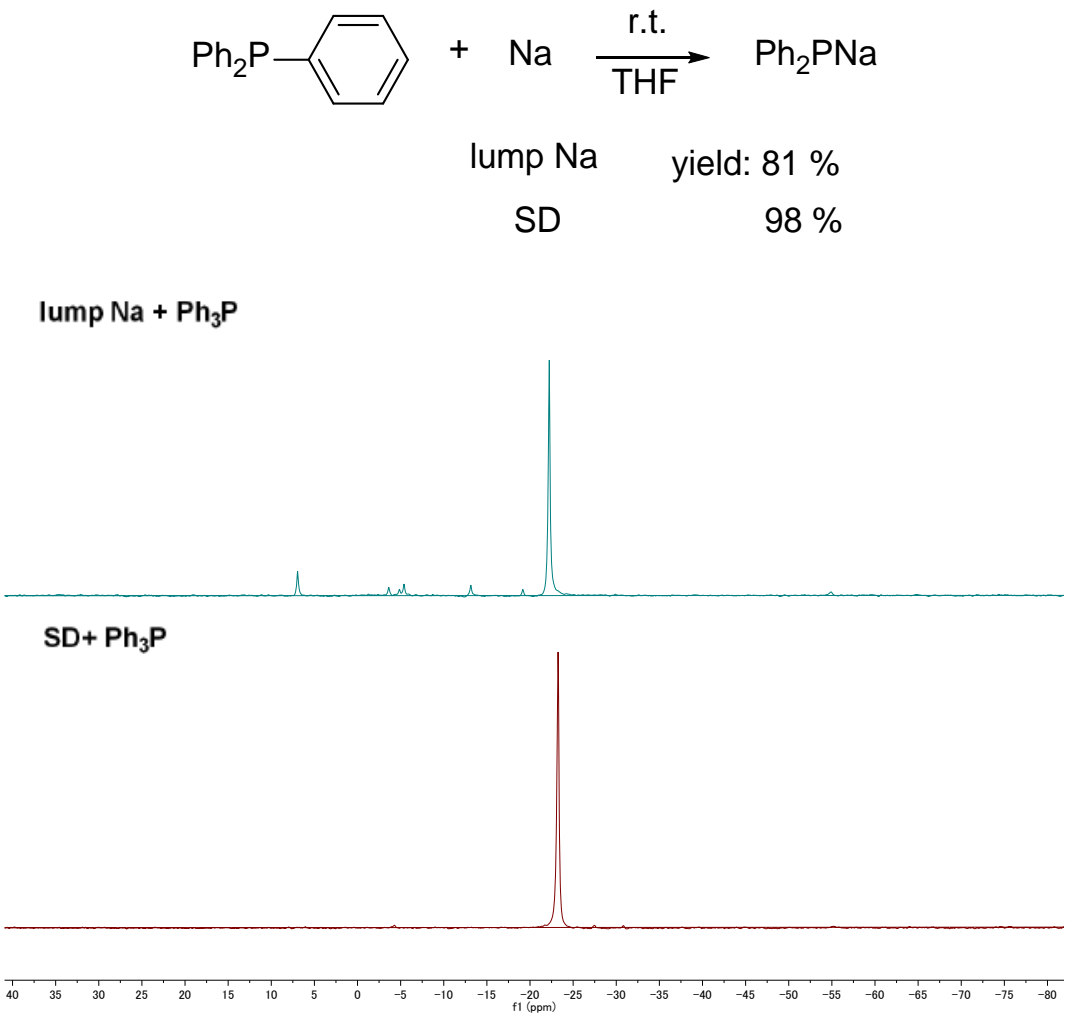

$\boldsymbol{P h}_{3} \boldsymbol{P}$ reacted with lump Na: Under argon, lump Na cut into small pieces (34.5 mg, $1.5 \mathrm{mmol}$ ) was added to the solution of $\mathrm{Ph}_{3} \mathrm{P}(0.13 \mathrm{~g}, 0.5 \mathrm{mmol})$ in THF $(1 \mathrm{~mL})$ at room temperature. After 18 hours the reaction mixture was analyzed using ${ }^{31} \mathrm{P}$ NMR.

$\boldsymbol{P h}_{3} \boldsymbol{P}$ reacted with $S \mathbf{D}$ : Under argon, to the solution of $\mathrm{Ph}_{3} \mathrm{P}(0.13 \mathrm{~g}, 0.5 \mathrm{mmol})$ in THF $(1 \mathrm{~mL})$, was added $\mathrm{SD}(0.15 \mathrm{~mL}, 1.5 \mathrm{mmol}, 10 \mathrm{~mol} / \mathrm{L})$ at room temperature. 
Preparation of $\mathbf{P h}{ }_{2} \mathbf{P N a}$ in gram scale: Under nitrogen atmosphere, $\mathrm{Ph}_{3} \mathrm{P}(2.6 \mathrm{~g}, 10 \mathrm{mmol})$ was dissolved in THF $(20 \mathrm{~mL})$, and then $\mathrm{SD}(3 \mathrm{~mL}, 30 \mathrm{mmol}, 10 \mathrm{~mol} / \mathrm{L})$ was added at room temperature. After 2 hours the reaction mixture was analyzed using ${ }^{31} \mathrm{P}$ NMR spectroscopy showing $\mathrm{Ph}_{2} \mathrm{PNa}$ was generated almost quantitatively. The excessive sodium was removed by centrifugation and $\mathrm{Ph}_{2} \mathrm{PNa}$ was obtained as a red brown transparent solution.

\section{2-II: Reaction of $\mathrm{Ph}_{3} \mathrm{P}$ with $\mathrm{K}$.}

Figure S15.

$$
\mathrm{Ph}_{2} \mathrm{P}-\mathrm{Ph} \underset{\mathrm{THF}, 25{ }^{\circ} \mathrm{C}}{\stackrel{2 \mathrm{~K}}{\longrightarrow}} \mathrm{Ph}_{2} \mathrm{PK} \text { low yield }
$$

$\mathbf{P h}_{3} \boldsymbol{P}$ reacted with $\mathbf{K}$ : Under argon, lump K (58.6 mg, $1.5 \mathrm{mmol}$ ) cut into small pieces was added to the solution of $\mathrm{Ph}_{3} \mathrm{P}(0.13 \mathrm{~g}, 0.5 \mathrm{mmol})$ in THF $(1 \mathrm{~mL})$ at room temperature. After 16 hours the reaction mixture was analyzed using ${ }^{31} \mathrm{P} \mathrm{NMR}$. $\mathrm{Ph}_{2} \mathrm{PK}$ (broad, $\delta=-6.40-9.07 \mathrm{ppm}$ ). The mixture was quenched with $n$-BuBr, and a mixture of phosphorus compounds were obtained.

Figure S16: ${ }^{31} \mathrm{P}-\mathrm{NMR}$ of $\mathrm{Ph}{ }_{3} \mathrm{P}$ reacted with Figure S17: ${ }^{31} \mathrm{P}-\mathrm{NMR}$ after quenching with K $\mathrm{n}-\mathrm{BuBr}$

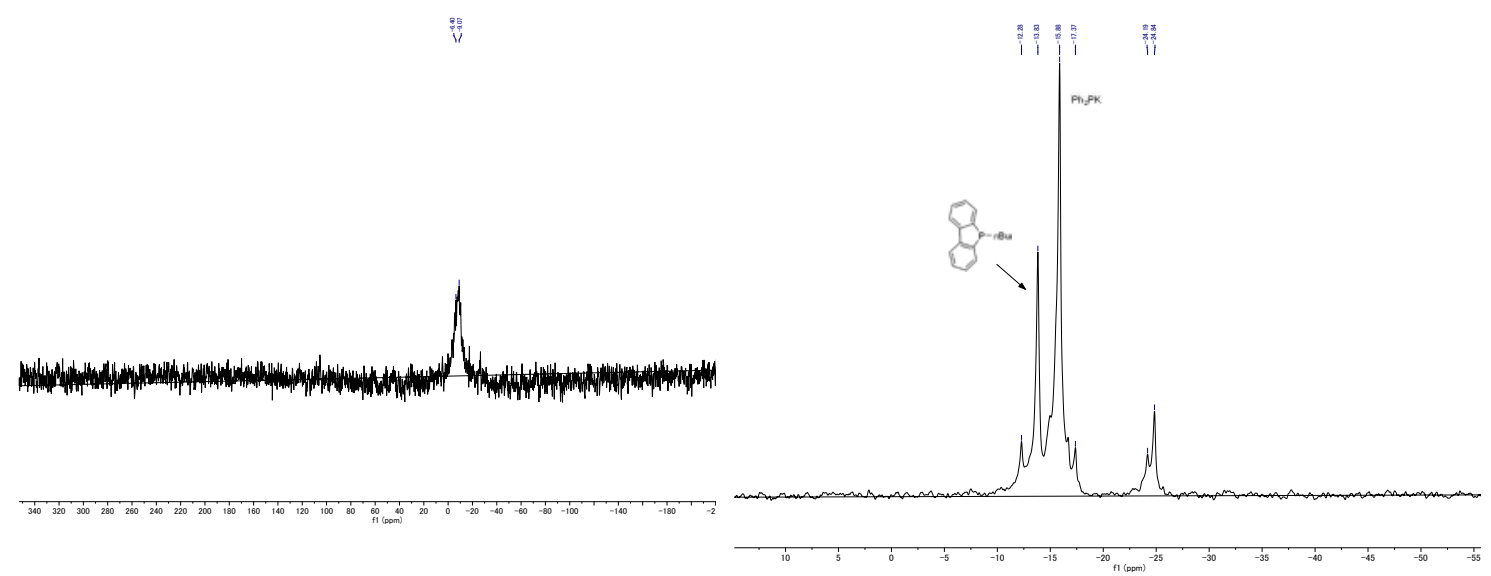




\section{2-III: Reactions of $\mathbf{R}^{1} \mathbf{R}^{2} \mathbf{P P h}$ with SD .}

Table S2: Selectivity of C-P Bond Cleavage.

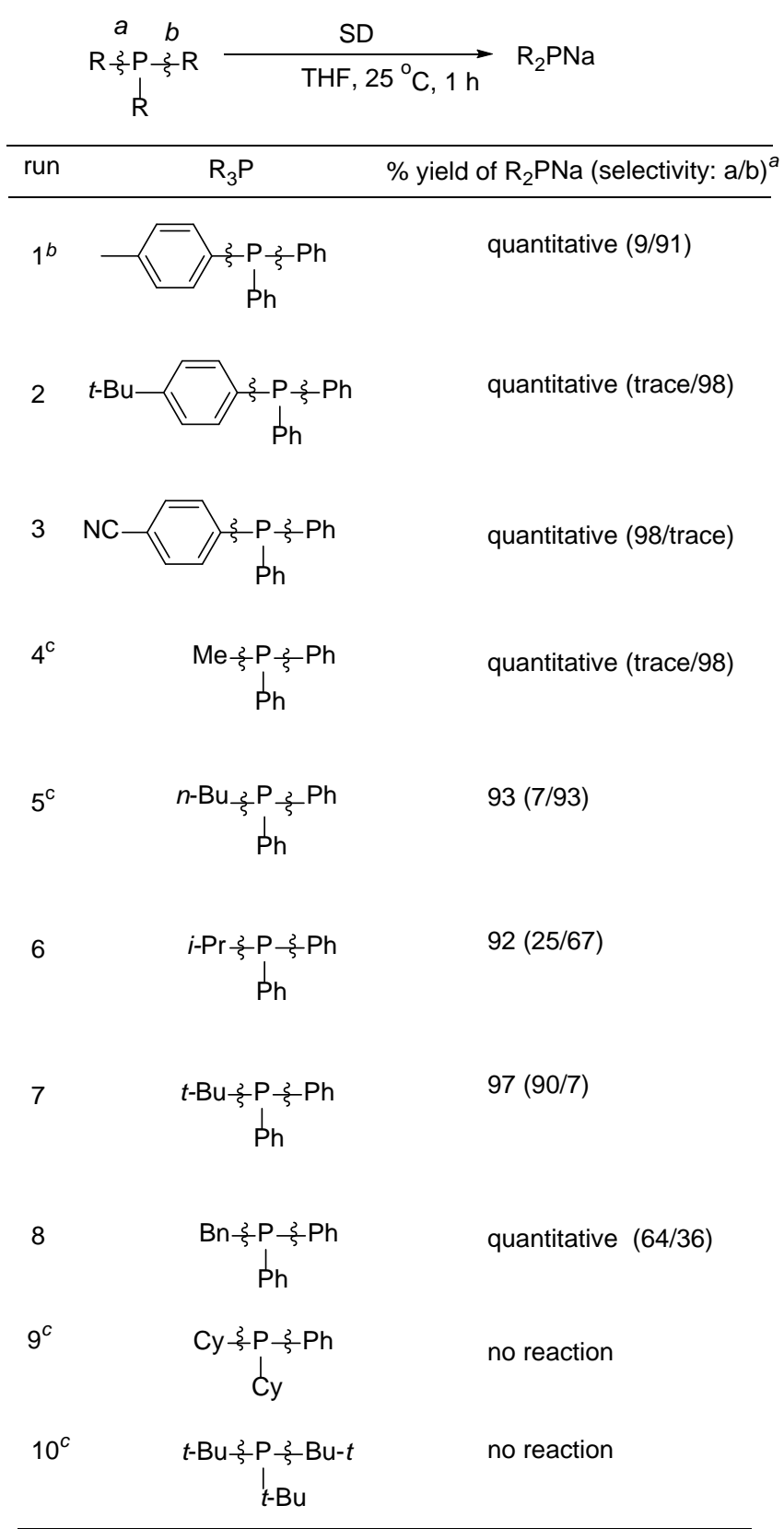

${ }^{a} 2.0 \mathrm{mmol}$ SD was added to $0.5 \mathrm{mmol}$ tertiary phosphine $\mathrm{R}_{3} \mathrm{P} \mathbf{1}$ dissolved in $1.0 \mathrm{~mL}$ THF at room temperature, and the resulted mixture was stirred for $1 \mathrm{~h}$ under nitrogen. Yields refer to a combined yield of the phosphides determined by ${ }^{31} \mathrm{P}$ NMR spectroscopy. ${ }^{b} 6.0 \mathrm{mmol}$ SD was dropped in the mixture of $2.0 \mathrm{mmol} p-\mathrm{CH}_{3} \mathrm{C}_{6} \mathrm{H}_{4} \mathrm{Ph}_{2} \mathrm{P}$ and $4 \mathrm{~mL}$ THF under $-30{ }^{\circ} \mathrm{C}$, after warmed to $67{ }^{\circ} \mathrm{C}$ reacted for $16 \mathrm{~h} .{ }^{c} 3.0 \mathrm{mmol}$ SD was used. ${ }^{\mathrm{d}} \mathrm{Conducted}$ at $67{ }^{\circ} \mathrm{C}$ for $16 \mathrm{~h}$.

run 1: Under argon atmosphere, $p$-tolyldiphenylphosphine $(0.55 \mathrm{~g}, 2 \mathrm{mmol})$ was dissolved in THF (4 mL), and then $\mathrm{SD}(0.6 \mathrm{~mL}, 6 \mathrm{mmol}, 10 \mathrm{~mol} / \mathrm{L})$ was added at $-30^{\circ} \mathrm{C}$. The solution was warmed to room temperature and stirred for $2 \mathrm{~h}$. Then, the solution was heated at $67^{\circ} \mathrm{C}$ for $16 \mathrm{~h} .{ }^{31} \mathrm{P}$ NMR, 
$\delta=-26.18\left(\mathrm{Ph}_{2} \mathrm{PNa}, 91 \%\right),-23.57$ (p-tolyPhPNa, 9\%).

Figure S18: ${ }^{31}$ P-NMR spectrum of run 1

in

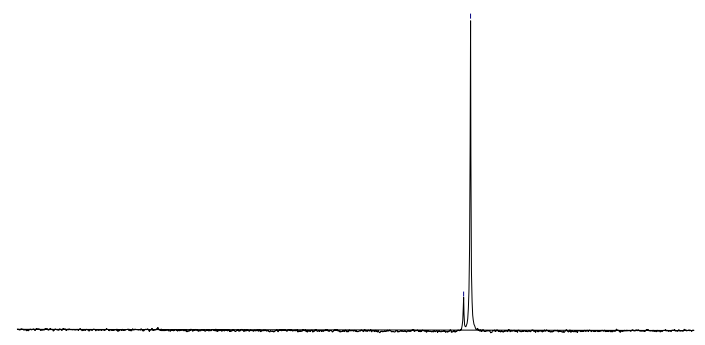

run 2: Under argon, $\left(t-\mathrm{BuC}_{6} \mathrm{H}_{4}\right) \mathrm{Ph}_{2} \mathrm{P}(0.16 \mathrm{~g}, 0.5 \mathrm{mmol})$ was dissolved in THF $(1.0 \mathrm{~mL})$, and then $\mathrm{SD}(0.2 \mathrm{~mL}, 2.0 \mathrm{mmol}, 10 \mathrm{~mol} / \mathrm{L})$ was added at room temperature for 1 hour. ${ }^{31} \mathrm{P} \mathrm{NMR}, \delta=-23.14$ $\left(t-\mathrm{BuC}_{6} \mathrm{H}_{4} \mathrm{PhPNa}, 98 \%\right)$.

The products were further confirmed by quenching with $n$-BuBr and analyzed by GC-Mass showing that $t-\mathrm{BuC}_{6} \mathrm{H}_{4} \mathrm{PhPn}$-Bu was generated.

Figure S19: ${ }^{31} \mathrm{P}-\mathrm{NMR}$ spectrum of run 2

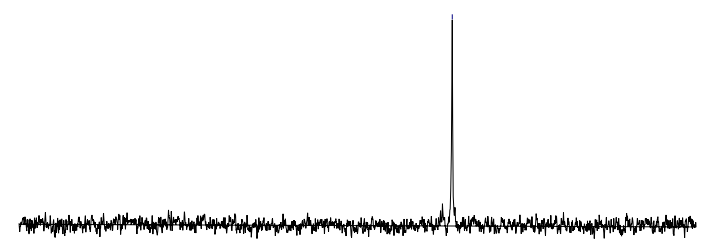

run 3: Similar to run 2, $\left(p-\mathrm{NCC}_{6} \mathrm{H}_{4}\right) \mathrm{Ph}_{2} \mathrm{P}(0.14 \mathrm{~g}, 0.5 \mathrm{mmol})$ reacted with $2.0 \mathrm{mmol} \mathrm{SD}$ at room temperature for 1 hour. The mixture was further quenched using $n-\mathrm{BuBr}(0.1 \mathrm{~mL})$, and $n-\mathrm{BuPh}_{2} \mathrm{P}$ was obtained. 

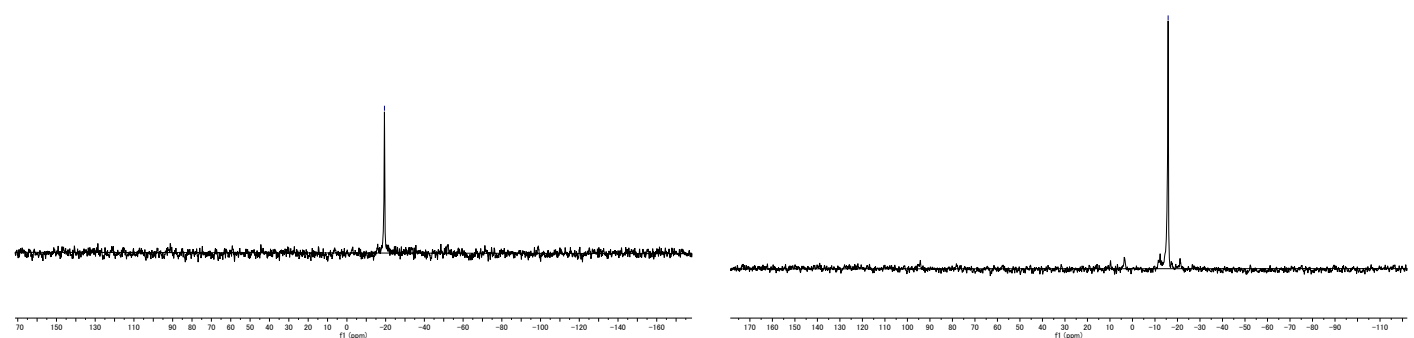

run 4: Similar to run 1 , methyldiphenylphosphine $(92.5 \mu \mathrm{L}, 0.5 \mathrm{mmol})$ reacted with $\mathrm{SD}(0.3 \mathrm{~mL}$, $3.0 \mathrm{mmol}, 10 \mathrm{~mol} / \mathrm{L}$ ) at room temperature. After stirred 1 hour the reaction mixture was analyzed by ${ }^{31} \mathrm{P}$ NMR spectroscopy, showing MePhPNa $(\delta=-80.27)$ was generated exclusively.

Preparation of MePhPNa in gram scale: Under argon, methyl diphenylphosphine (1.85 mL, 10 mmol) was dissolved in THF $(20 \mathrm{~mL})$, and then SD $(4 \mathrm{~mL}, 40 \mathrm{mmol}, 10 \mathrm{~mol} / \mathrm{L})$ was added at room temperature. Then the mixture was heated at $67^{\circ} \mathrm{C}$ for 16 hours. Excessive Na was separated from the solution by centrifugation and a red-brown transparent solution of PhMePNa was obtained. The solution was analyzed using ${ }^{31} \mathrm{P}$ NMR spectroscopy showing PhMePNa was generated over $>98 \%$ purity.

Figure S22: ${ }^{31} \mathrm{P}-\mathrm{NMR}$ spectrum of run 4

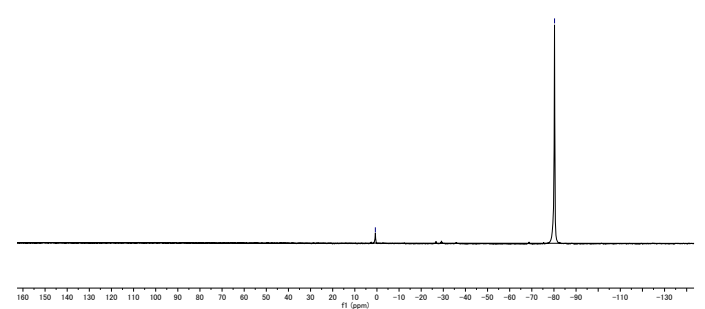

run 5): Similar to run 4, butyldiphenylphosphine ( $0.48 \mathrm{~g}, 2.0 \mathrm{mmol}$ ) reacted with SD ( $0.3 \mathrm{~mL}, 3.0$ mmol, $10 \mathrm{~mol} / \mathrm{L}$ ) in THF at room temperature and $67{ }^{\circ} \mathrm{C}$ for 16 hours. ${ }^{31} \mathrm{P}$ NMR showed that 
$\mathrm{Ph} n \mathrm{BuPNa}(\delta=-53.69)$ was generated in $93 \%$ selectivity.

Figure S23: ${ }^{31} \mathrm{P}-\mathrm{NMR}$ spectrum of run 5

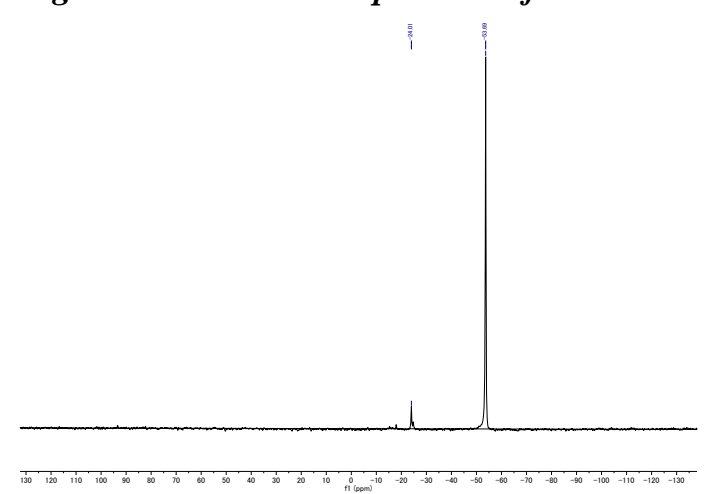

run 6: Similar to run 2, iso-propyldiphenylphosphine $(0.13 \mathrm{~mL}, 0.5 \mathrm{mmol})$ reacted with $2.0 \mathrm{mmol}$ SD in THF. The mixture was analyzed using NMR spectroscopy, $\delta=-14.24$ (i-PrPhPNa, 25\%), $-24.43\left(\mathrm{Ph}_{2} \mathrm{PNa}, 67 \%\right)$.

Figure S24: ${ }^{31}$ P-NMR spectrum of run 7

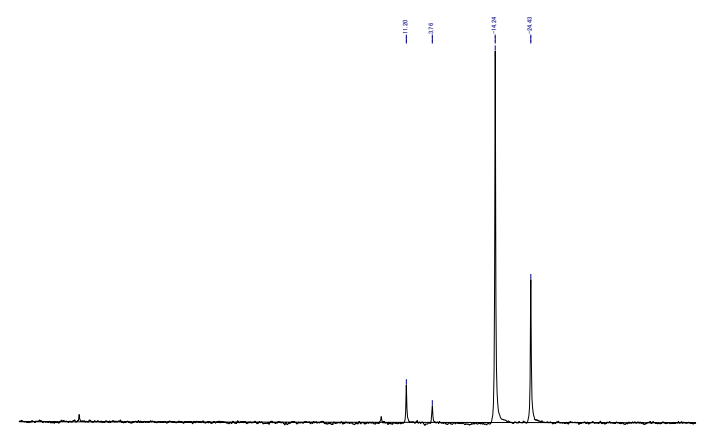

run 7: Under argon atmosphere, tert-butyldiphenylphosphine $(0.12 \mathrm{~mL}, 0.5 \mathrm{mmol})$ was dissolved in THF $(1 \mathrm{~mL})$, and then SD $(0.2 \mathrm{~mL}, 2 \mathrm{mmol}, 10 \mathrm{~mol} / \mathrm{L})$ was added. The mixture was stirred at room temperature for 1 hour. The sample was analyzed using ${ }^{31} \mathrm{P}$ NMR spectroscopy, $\delta=-23.16$ $\left(\mathrm{Ph}_{2} \mathrm{PNa}, 90 \%\right), 16.20$ (Pht-BuPNa, 7\%) 
Figure S25: ${ }^{31}$ P-NMR for run 7

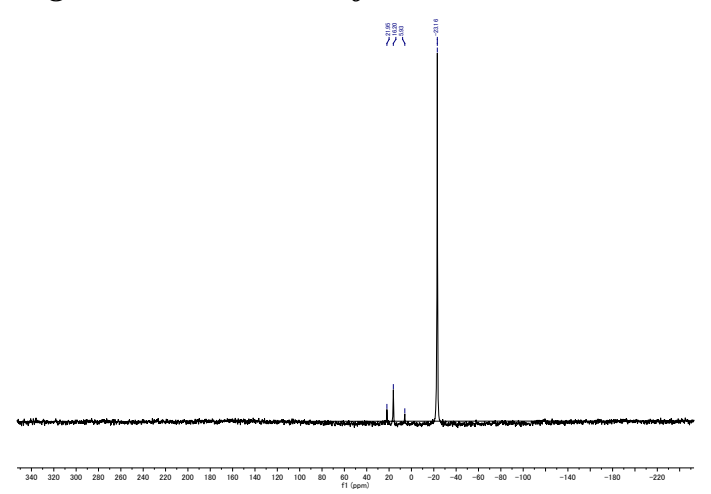

run 8: Similar to run 2, benzyldiphenylphosphine $(0.14 \mathrm{~mL}, 0.5 \mathrm{mmol})$ reacted with $2.0 \mathrm{mmol} \mathrm{SD}$. ${ }^{31} \mathrm{P}$ NMR spectroscopy showed two species were generated $\delta=-22.61\left(\mathrm{Ph}_{2} \mathrm{PNa}, 64 \%\right),-16.98$ (BnPhPNa, 36\%).

Figure S26: ${ }^{31}$ P-NMR spectrum of run 8

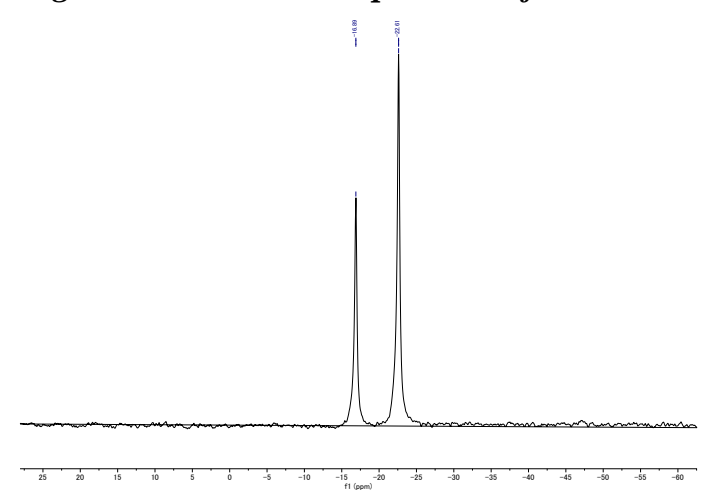

run 9: Under argon atmosphere, dicyclohexylphenylphosphine (0.14 g, $0.5 \mathrm{mmol})$ was dissolved in THF $(1 \mathrm{~mL})$, and then SD $(0.2 \mathrm{~mL}, 2 \mathrm{mmol}, 10 \mathrm{~mol} / \mathrm{L})$ was added. The mixture was stirred at room temperature and then heated at $67{ }^{\circ} \mathrm{C}$ for 16 hours. ${ }^{31} \mathrm{P}$ NMR showed the starting material remained unreacted.

run 10: Similar to run 9 , tri-tert-butylphosphane $(0.14 \mathrm{~mL}, 0.5 \mathrm{mmol})$ reacted with SD. No reaction was observed as confirmed by ${ }^{31} \mathrm{P}$ NMR. 


\section{Part 3. Reaction of $\mathrm{Ph}_{2} \mathrm{PNa}$ with ArX.}

\section{3-I: Reactions of $\mathrm{PhX}$ with $\mathrm{Ph}_{2} \mathrm{PNa}$.}

Table S3: Reactions of $\mathrm{Ph}_{2} \mathrm{PNa}$ with $\mathrm{PhX}$ Forming $\mathrm{Ph}_{3} \mathrm{P}$.

\begin{tabular}{|c|c|c|c|c|c|}
\hline run & $X$ & $\begin{array}{l}\text { temp } \\
\left({ }^{\circ} \mathrm{C}\right)\end{array}$ & $\begin{array}{l}\text { time } \\
\text { (h) }\end{array}$ & additive & $\begin{array}{c}\text { \% yield } \mathrm{Ph}_{3} \mathrm{P} \\
\quad\left(\left(\mathrm{Ph}_{2} \mathrm{P}\right)_{2}\right)^{\mathrm{a}}\end{array}$ \\
\hline 1 & I & 25 & 1 & none & $36(60)$ \\
\hline 2 & I & 25 & 0.5 & 15-crown-5 & 73 (25) \\
\hline 3 & $\mathrm{Br}$ & 25 & 1 & none & 48 (23) \\
\hline 4 & $\mathrm{Br}$ & 25 & 2 & 15-crown-5 & $76(20)$ \\
\hline $5^{b}$ & $\mathrm{Br}$ & 25 & 2 & 15-crown-5 & 78 (16) \\
\hline 6 & $\mathrm{Br}$ & 25 & 2 & 18-crown-6 & 72 (19) \\
\hline 7 & $\mathrm{Cl}$ & 25 & 16 & none & trace (trace) \\
\hline 8 & $\mathrm{Cl}$ & 67 & 16 & none & $9(3)$ \\
\hline 9 & $\mathrm{Cl}$ & 67 & 16 & HMPA & $78(2)$ \\
\hline 10 & $\mathrm{Cl}$ & 67 & 16 & 12-crown-4 & $39(0)$ \\
\hline 11 & $\mathrm{Cl}$ & 67 & 16 & 15-crown-5 & $98(0)$ \\
\hline 12 & $\mathrm{Cl}$ & 67 & 16 & 18-crown-8 & $89(0)$ \\
\hline $13^{c}$ & $\mathrm{Cl}$ & 100 & 3 & none & 97 (trace) \\
\hline 14 & $\mathrm{~F}$ & 67 & 16 & none & $4(0)$ \\
\hline 15 & $\mathrm{~F}$ & 67 & 16 & HMPA & $96(0)$ \\
\hline 16 & $\mathrm{~F}$ & 67 & 16 & 15-crown-5 & $99(0)$ \\
\hline 17 & OTf & 67 & 16 & none & $7(81)$ \\
\hline 18 & OTf & 67 & 16 & 15-crown-5 & $3(95)$ \\
\hline
\end{tabular}

Reaction conditions: ${ }^{a}$ Reaction conditions: $\mathrm{PhX}(0.4 \mathrm{mmol})$ and was added to a mixture of $\mathrm{Ph}_{2} \mathrm{PNa}(0.2 \mathrm{mmol}$ in $0.6 \mathrm{~mL}$ THF) and an additive $(0.25 \mathrm{mmol})$ under nitrogen. Yields refer to NMR yields determined by ${ }^{31} \mathrm{P}$ NMR spectroscopy. ${ }^{b}$ Conducted in $1.2 \mathrm{~mL}$ THF. ${ }^{c}$ Added $0.6 \mathrm{~mL}$ DMF in the reaction as solution and stirred 3 hours under $100^{\circ} \mathrm{C}$.

Summary: $\mathrm{Ph}_{2} \mathrm{PNa}$ reacted with $\mathrm{PhI}$ and $\mathrm{PhBr}$ only gave low yields of $\mathrm{Ph}_{3} \mathrm{P}$ (runs 1 and 3) because of the formation of $\left(\mathrm{Ph}_{2} \mathrm{P}\right)_{2}$. In the presence of crown ether, the yields of $\mathrm{Ph}_{3} \mathrm{P}$ were improved (runs 2-6). $\mathrm{PhCl}$ and $\mathrm{PhF}$ hardly reacted with $\mathrm{Ph}_{2} \mathrm{PNa}$ at room temperature in the absence of an additive (runs 7, 8 and 14). When crown ether or hexamethylphosphoramide (HMPA) was added to this reaction, they produced high yields of the products at $67^{\circ} \mathrm{C}$ (runs 9,11 , 
12, 15 and 16). When DMF was used as the solvent, the reaction also went efficiently. Phenyl trifluoromethanesulfonate did not give $\mathrm{Ph}_{3} \mathrm{P}$; high yields of $\left(\mathrm{Ph}_{2} \mathrm{P}\right)_{2}$ (runs 17 and 18) were obtained. The yields of the coupling product $\mathrm{Ph}_{3} \mathrm{P}$ follow an increasing order of $\mathrm{PhI}<\mathrm{PhBr}<\mathrm{PhF}=\mathrm{PhCl}$.

Figure S27: Yields of $\mathrm{Ph}_{3} \mathrm{P}$ by the reaction of $\mathrm{Ph}_{2} \mathrm{PNa}$ with $\mathrm{PhX}$ follow a decreasing order.<smiles>Fc1ccccc1-c1cccc(-c2ccccc2Br)c1-c1ccccc1I</smiles>

\section{3-II: Reactions of $\mathrm{X}-\mathrm{C}_{4} \mathrm{H}_{6}-\mathrm{X}$ with $\mathrm{Ph}_{2} \mathrm{PNa}$.}

Table S4: Comparison of Reactivity of Two Halogen Atoms.

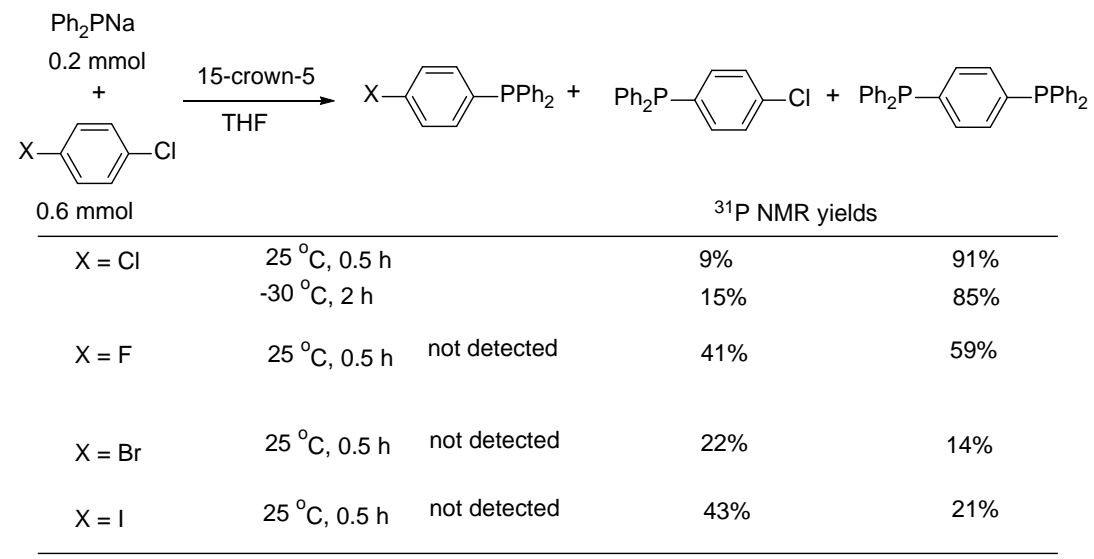

Figure S28: $\mathrm{Ph}_{2} \mathrm{PNa}$ reacted with 1,4-dichlorobenzene under different temperatures.

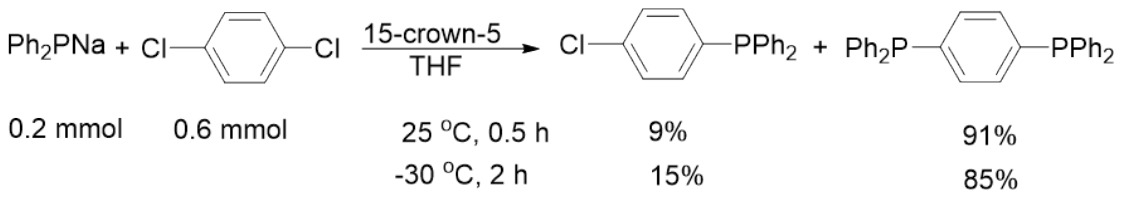

Reaction at $25^{\circ} \mathrm{C}$ : To a solution of $\mathrm{Ph}_{2} \mathrm{PNa}(0.21 \mathrm{mmol}$ in $0.6 \mathrm{~mL}$ THF) and 15-crown 5-ether (50 $\mu \mathrm{L}, 0.25 \mathrm{mmol}$ ), 1 ,4-dichlorobenzene ( $88.2 \mathrm{mg}, 0.6 \mathrm{mmol}$, in $0.5 \mathrm{~mL}$ THF) was added at room temperature. After 0.5 hour, the mixture was analyzed. ${ }^{31} \mathrm{P}$ NMR $\delta=-5.03$ (bisphosphine, 91\%), -5.78 (monophosphine, 9\%).

Reaction at $-30^{\circ} \mathrm{C}$ : A solution of $\mathrm{Ph}_{2} \mathrm{PNa}(0.21 \mathrm{mmol}$ in $0.6 \mathrm{~mL}$ THF) and 15-crown 5-ether (50 $\mu \mathrm{L}, 0.25 \mathrm{mmol}$ ) was cooled to $-30^{\circ} \mathrm{C}$, and a THF solution of 1,4-dichlorobenzene (88.2 $\mathrm{mg}, 0.3$ mmol, in $0.5 \mathrm{~mL}$ THF) was slowly added. After 2 hours, the mixture was warmed to room temperature. The sample was analyzed using ${ }^{31} \mathrm{P}$ NMR. $\delta=-5.17$ (bisphosphine, 85\%), -5.89 (monophosphine, 15\%). 
Figure S29: at room temperature

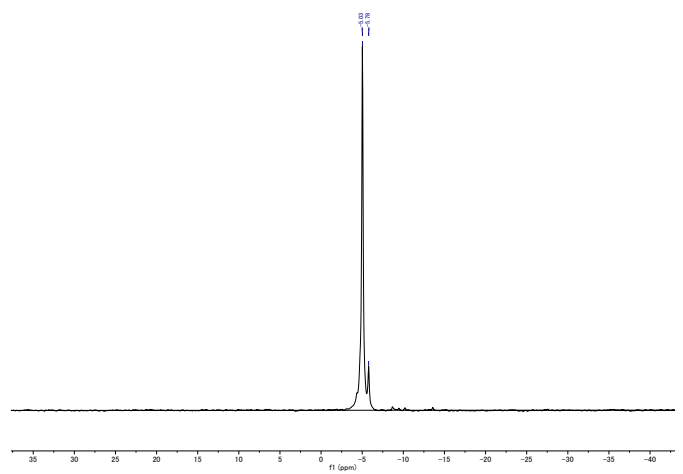

Figure S30: at $-30^{\circ} \mathrm{C}$

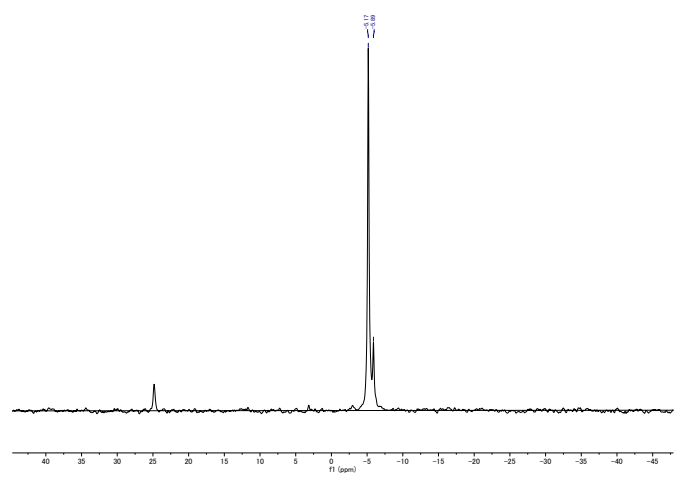

Figure S31: $\mathrm{Ph}_{2} \mathrm{PNa}$ reacted with 1-chloro-4-fluorobenzene under different temperatures.

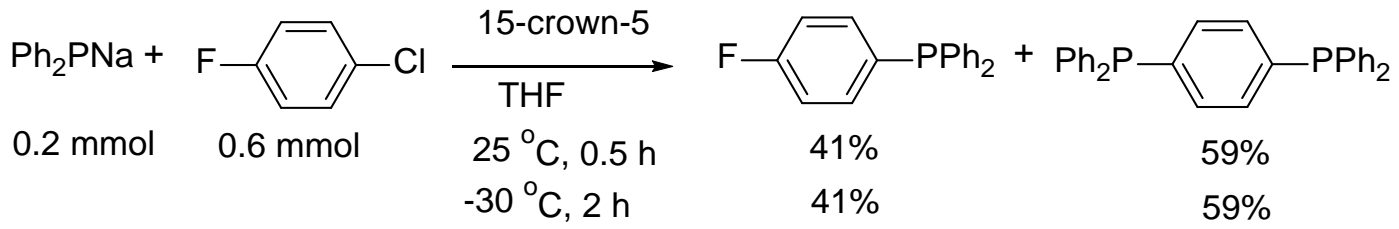

Similarly, 1-chloro-4-fluorobenzene (31.9 $\mu \mathrm{L}, 0.3 \mathrm{mmol}$, in $0.5 \mathrm{~mL}$ THF) was allowed to react with $\mathrm{Ph}_{2} \mathrm{PNa}$, and the contributions of the products were determined by ${ }^{31} \mathrm{P}$ NMR.

Room temperature: $\delta=-5.10$ (bisphosphine, 59\%), -5.83 (monophosphine, 41\%).

$-30^{\circ} \mathrm{C}: \delta=-5.14$ (bisphosphine, 59\%), -5.87 (monophosphine, 41\%).

Figure S32: at room temperature

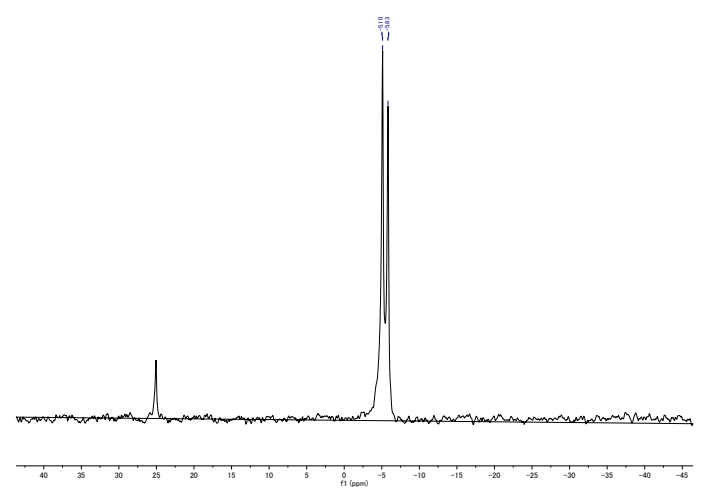

Figure S33: at $-30^{\circ} \mathrm{C}$

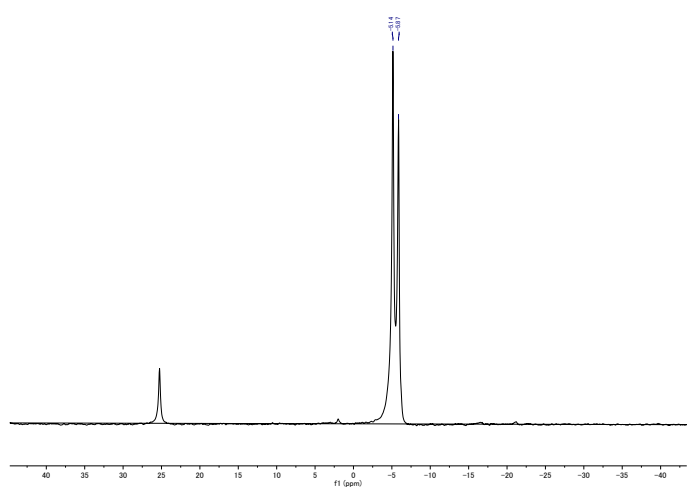


Figure S34: $\mathrm{Ph}_{2} \mathrm{PNa}$ reacted with 4-bromochlorobenzene.

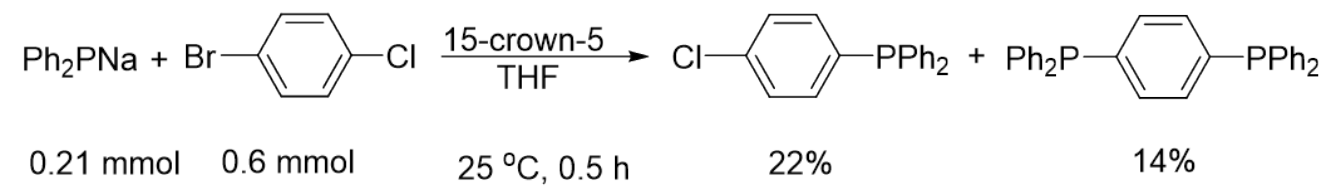

Similarly, 4-bromochlorobenzene (57.4 mg, $0.3 \mathrm{mmol}$, in $0.5 \mathrm{~mL}$ THF) was allowed to react with $\mathrm{Ph}_{2} \mathrm{PNa}$ at room temperature and analyzed by ${ }^{31} \mathrm{P}$ NMR. $\delta=-4.57$ (bisphosphine), -6.01 (monophosphine).

Figure S35: $\mathrm{Ph}_{2} \mathrm{PNa}$ reacted with 1-chloro-4-iodobenzene.

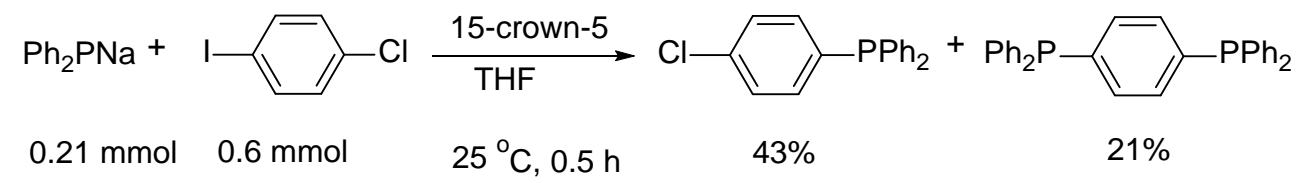

Similarly, 1-chloro-4-iodobenzene (71.5 mg, $0.3 \mathrm{mmol}$, in $0.5 \mathrm{~mL}$ THF) was allowed to react with $\mathrm{Ph}_{2} \mathrm{PNa}$ at room temperature and analyzed by ${ }^{31} \mathrm{P} \mathrm{NMR}$.

Figure S36: ${ }^{31} \mathrm{P}-\mathrm{NMR}$

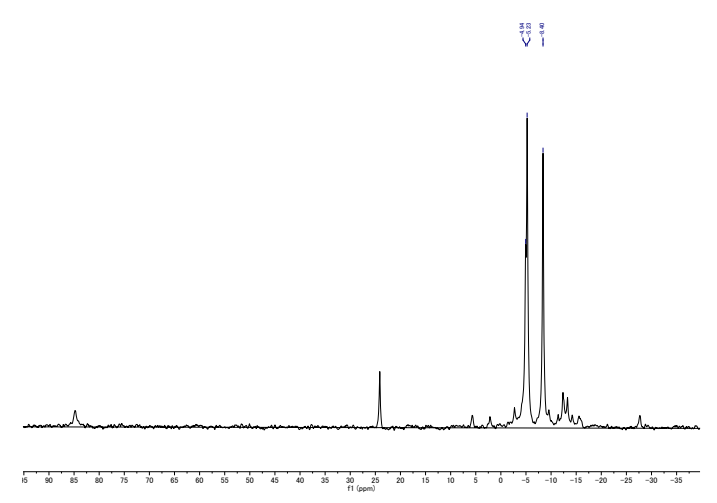


Part 4. Reactions of $\mathrm{Ph}_{2} \mathrm{PM}$ with aryl chlorides.

Figure S37.

$$
\begin{aligned}
& \mathrm{Ph}_{2} \mathrm{PM}+\mathrm{PhCl} \frac{\mathrm{HMPA}(0.2 \mathrm{mmol})}{\mathrm{THF}, 67^{\circ} \mathrm{C}, 16 \mathrm{~h}} \mathrm{Ph}_{3} \mathrm{P} \\
& 0.2 \mathrm{mmol} 0.3 \mathrm{mmol} \\
& \mathrm{M}=\mathrm{Li} \text {, not detected } \\
& \mathrm{M}=\mathrm{Na}, 78 \% \text { yield } \\
& \mathrm{M}=\mathrm{K}, 43 \% \text { yield }
\end{aligned}
$$

\section{The formation of $\mathrm{Ph}_{3} \mathrm{P}$ from $\mathrm{Ph}{ }_{2} \mathrm{PLi}$ :}

Step $1 \mathrm{Ph}_{2} \mathrm{PLi}(0.5 \mathrm{M})$ was prepared from $\mathrm{PhLi}(0.5 \mathrm{~mL}, 1.0 \mathrm{~mol}, 2.0 \mathrm{M}$ solution in cyclohexane/diethyl ether) and $\mathrm{Ph}_{2} \mathrm{PH}(172 \mu \mathrm{L}, 1.0 \mathrm{~mol})$ in THF $(2 \mathrm{~mL}) .{ }^{31} \mathrm{P}$ NMR $\delta=-21.82(>$ 99\% purity).

Step 2 To the solution of $\mathrm{Ph}_{2} \mathrm{PLi}(0.5 \mathrm{~mL}, 0.25 \mathrm{mmol}, 0.5 \mathrm{~mol} / \mathrm{L})$ with HMPA (43 $\mu \mathrm{L}, 0.25 \mathrm{mmol}$ ), chlorobenzene (30 $\mu \mathrm{L}, 0.3 \mathrm{mmol}$ ) was added, and the mixture was stirred for 1 hour at room temperature, and then heated to $67^{\circ} \mathrm{C}$ for additional 16 hours. $\mathrm{No}^{\mathrm{Ph}}{ }_{3} \mathrm{P}$ was observed.

Figure S38: ${ }^{31}$ P NMR

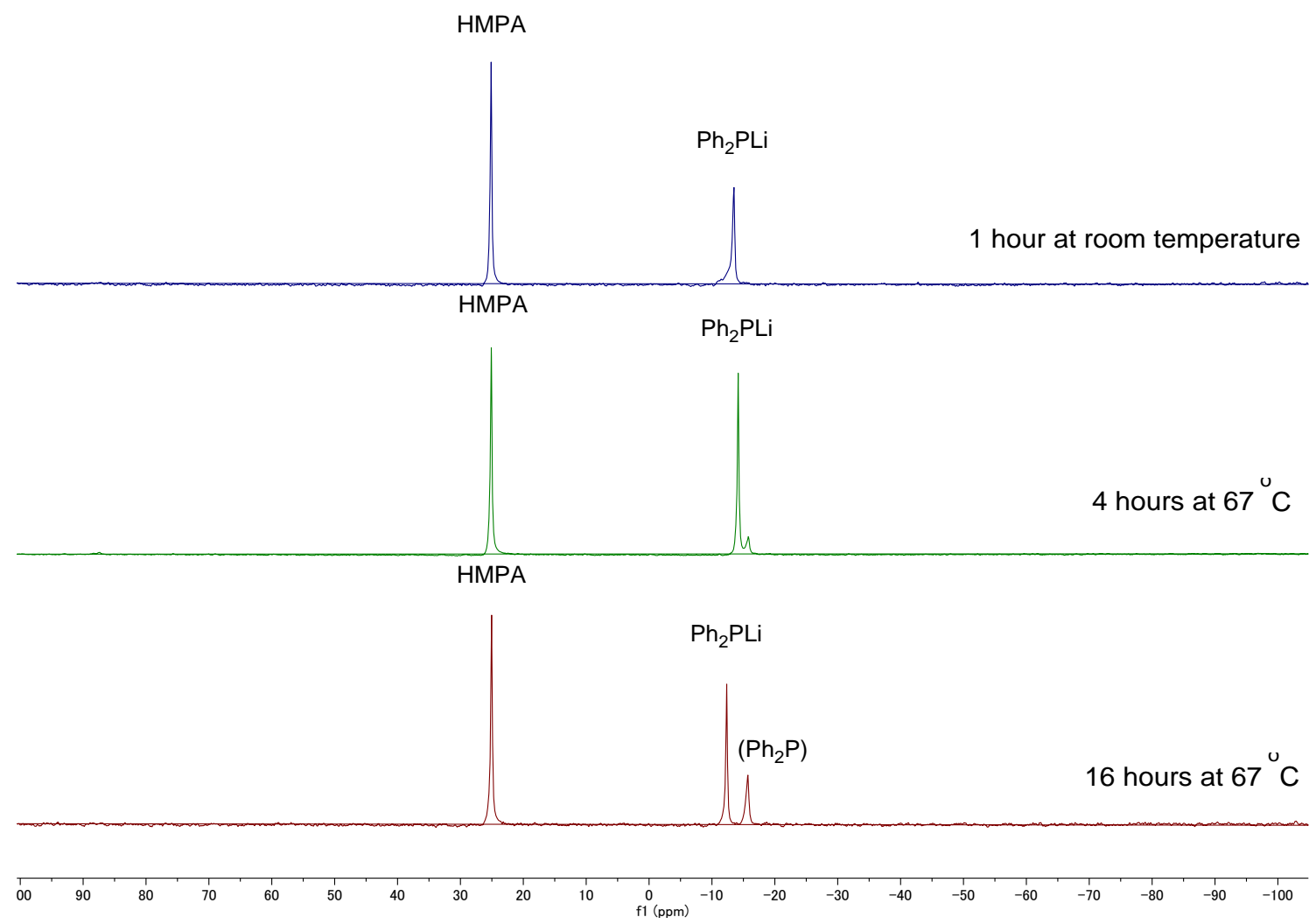


The formation of $\boldsymbol{P h}{ }_{3} \boldsymbol{P}$ from $\boldsymbol{P h}{ }_{2}$ PNa: To a THF solution of $\mathrm{Ph}_{2} \mathrm{PNa}$ (0.21 mmol in $\left.0.6 \mathrm{mLTHF}\right)$ and HMPA (43 $\mu \mathrm{L}, 0.25 \mathrm{mmol}$ ), chlorobenzene (30 $\mu \mathrm{L}, 0.3 \mathrm{mmol}$ ) was added at room temperature and the mixture was stirred for 1 hour, and heated at $67^{\circ} \mathrm{C}$

Figure S39: ${ }^{31}$ P NMR
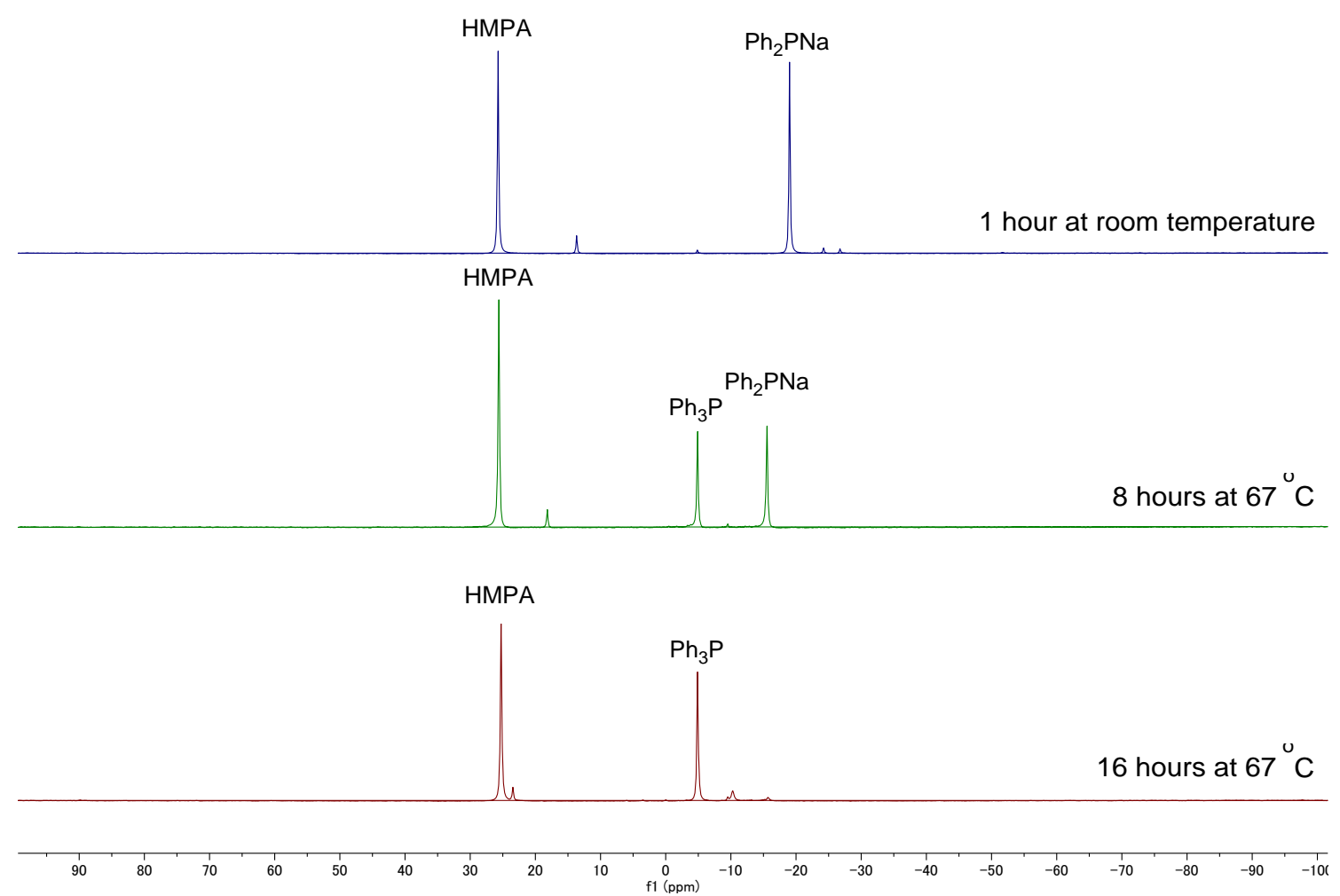

The formation of $\mathrm{Ph}_{3} \mathrm{P}$ from $\mathrm{Ph}_{2} \mathrm{PK}$ :

Step 1, $\mathrm{Ph}_{2} \mathrm{PK}(0.5 \mathrm{M})$ was prepared using metallic $\mathrm{K}(78 \mathrm{~mL}, 2 \mathrm{mmol})$ and $\mathrm{Ph}_{2} \mathrm{PCl}(90 \mu \mathrm{L}, 1.0$ $\mathrm{mol})$ in THF (2 mL) at room temperature. ${ }^{31} \mathrm{P}$ NMR of $\mathrm{Ph}_{2} \mathrm{PK}, \delta=-8.97$ (99\% purity).

Step 2, A mixture of $\mathrm{Ph}_{2} \mathrm{PK}(0.25 \mathrm{mmol}$ in $0.5 \mathrm{~mL}$ THF), HMPA (43 $\mu \mathrm{L}, 0.25 \mathrm{mmol}$ ), and chlorobenzene (30 $\mu \mathrm{L}, 0.3 \mathrm{mmol}$ ) was stirred for 1 hour at room temperature, and then warmed to $67^{\circ} \mathrm{C}$. After 3 days at $67^{\circ} \mathrm{C}, \mathrm{Ph}_{3} \mathrm{P}$ was generated in $98 \%$ yield. 
Figure S40: ${ }^{31}$ P NMR
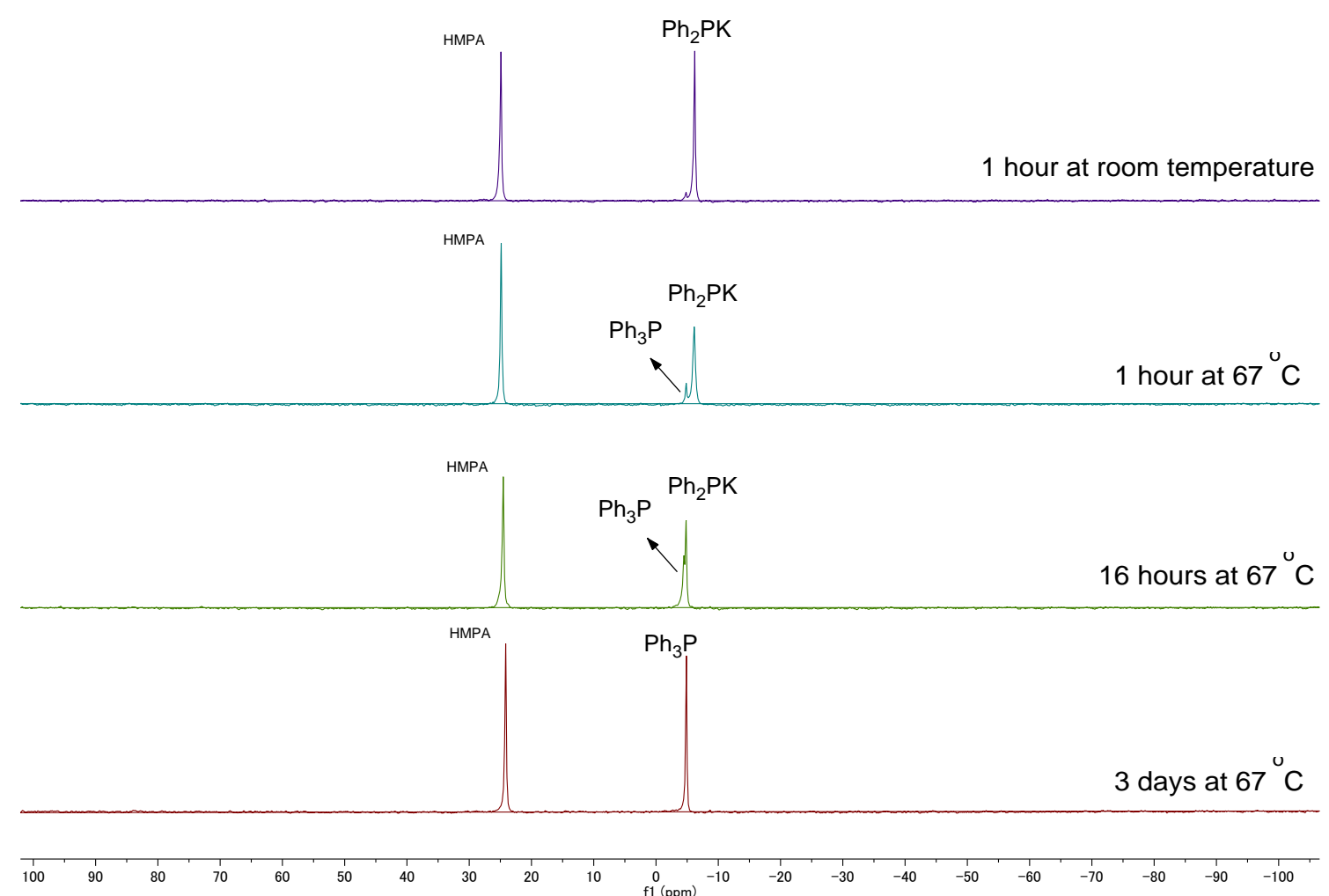

Part 5. Preparation of $\mathrm{Ph}_{2} \mathrm{PR}$ from $\mathrm{Ph}_{2} \mathrm{PNa}$ and $\mathrm{RCl}$.

Figure S41.

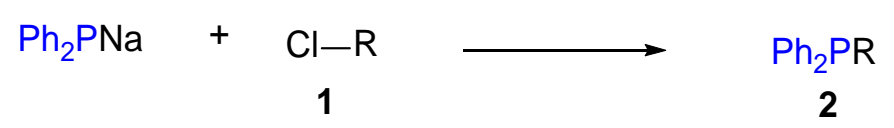

Typical procedure (method 1): Under nitrogen, to a mixture of $\mathrm{Ph}_{2} \mathrm{PNa}(0.21 \mathrm{mmol}$ in $0.6 \mathrm{~mL}$ THF ) and 15-crown 5-ether (50 $\mu \mathrm{L}, 0.25 \mathrm{mmol}$ ), chlorobenzene (30 $\mu \mathrm{L}, 0.3 \mathrm{mmol}$ ) was added at room temperature. The mixture was heated to $67^{\circ} \mathrm{C}$ and stirred for 16 hours. After heating, saturated ammonium chloride aqua solution $(2 \mathrm{~mL})$ was added, and the mixture was extracted with ethyl acetate $(20 \mathrm{~mL})$, washed with water $(3 \times 10 \mathrm{~mL})$, dried over magnesium sulfate. After removing volatiles, the residue was purified by column chromatography on silica gel (ethyl 
acetate/hexane $=1 / 10)$ to afford $2 \mathbf{a}(48.5 \mathrm{mg}, 88 \%$ yield $)$.

(Method 2): Under nitrogen, to $\mathrm{Ph}_{2} \mathrm{PNa}(0.21 \mathrm{mmol}$ in $0.6 \mathrm{~mL}$ THF) were added $N, N$-dimethyl-formamide (DMF) $(0.6 \mathrm{~mL})$ and chlorobenzene $(30 \mu \mathrm{L}, 0.3 \mathrm{mmol})$ at room temperature. The mixture was heated at $100{ }^{\circ} \mathrm{C}$ for 3 hours. After heating, saturated aqua solution of ammonium chloride $(2 \mathrm{~mL})$ was added, and the mixture was extracted with ethyl acetate (20 $\mathrm{mL})$, washed with water $(5 \times 10 \mathrm{~mL})$, dried over magnesium sulfate. After removing volatiles, the residues were purified using column chromatography on silica gel (ethyl acetate/hexane $=1 / 10$ ) to afford 2a (46.3 mg, 84\% yield).

\section{A gram-scale reaction (Preparation of $2 j$ in gram scale)}

Under nitrogen, to a mixture of $\mathrm{Ph}_{2} \mathrm{PNa}$ (5.2 mmol in $25 \mathrm{~mL}$ THF) and 15-crown 5-ether (1.1 mL, $5.5 \mathrm{mmol})$, 4-chlorobenzonitrile $(6 \mathrm{mmol})$ was added at room temperature. The reaction mixture was stirred for 16 hours, and then saturated aqua ammonium chloride solution $(15 \mathrm{~mL})$ was added. The mixture was extracted with ethyl acetate $(100 \mathrm{~mL})$, washed with water $(3 \times 20 \mathrm{~mL})$, dried over magnesium sulfate. After removing solvent, the residues were purified by column chromatography on silica gel (ethyl acetate/hexane $=1 / 10)$ to afford $2 \mathbf{j}(1.22 \mathrm{~g}, 82 \%)$.

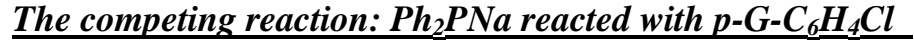

Under nitrogen, a mixture of chlorobenzene ( $30 \mu \mathrm{L}, 0.3 \mathrm{mmol}$ ), p-chlorotoluene (40.6 $\mu \mathrm{L}, 0.3$ mmol), 4-tert-butylchlorobenzene (50.1 $\mu \mathrm{L}, 0.3 \mathrm{mmol}$ ) and 4-chlorodiphenylmethane (54.8 $\mu \mathrm{L}$, $0.3 \mathrm{mmol})$ was added to a solution of $\mathrm{Ph}_{2} \mathrm{PNa}(0.21 \mathrm{mmol}$ in $0.6 \mathrm{~mL} \mathrm{THF})$ and 15 -crown 5-ether (50 $\mu \mathrm{L}, 0.25 \mathrm{mmol}$ ) at room temperature. The mixture was heated at $67^{\circ} \mathrm{C}$ for 16 hours, and analyzed by ${ }^{31}$ P NMR and GC-Mass. 
Figure S42: $\mathrm{Ph}_{2} \mathrm{PNa}$ reacted with a mixture of $\mathrm{p}-\mathrm{G}-\mathrm{C}_{6} \mathrm{H}_{4} \mathrm{Cl}$.

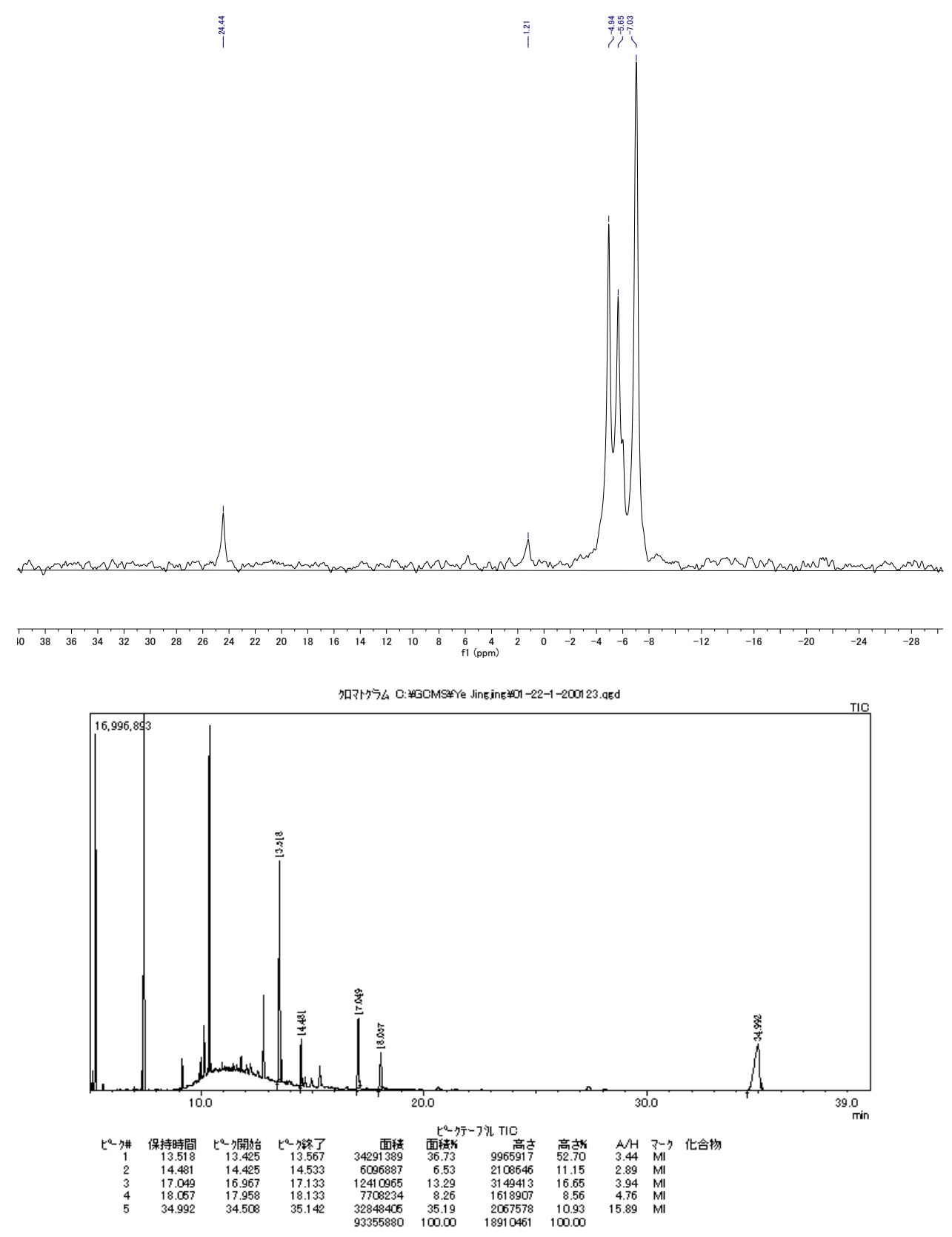



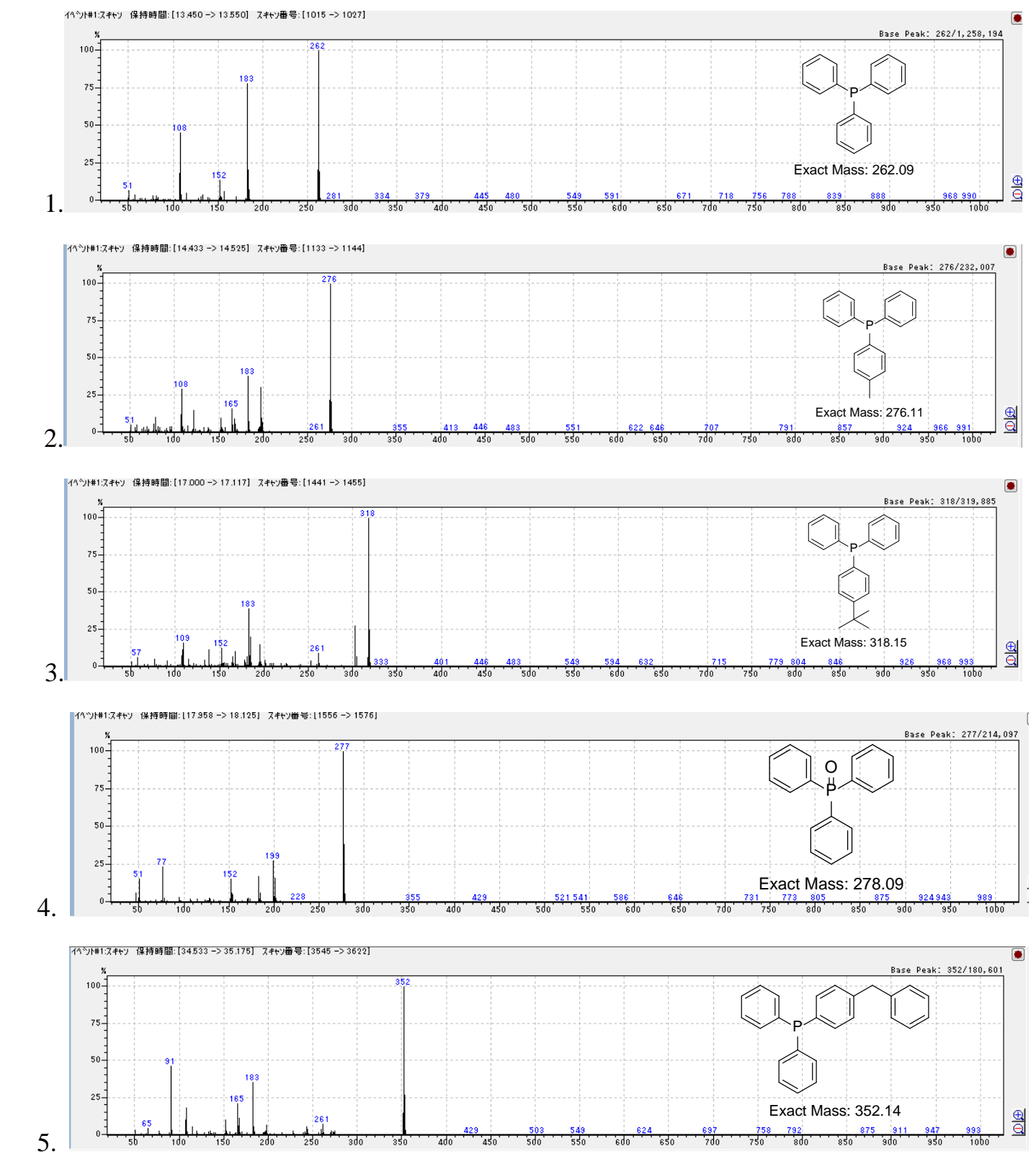

\section{Part 6. Reactions of $\mathbf{P h}_{2} \mathbf{P N a}$ with tert-alkyl halides.}

Figure S43.

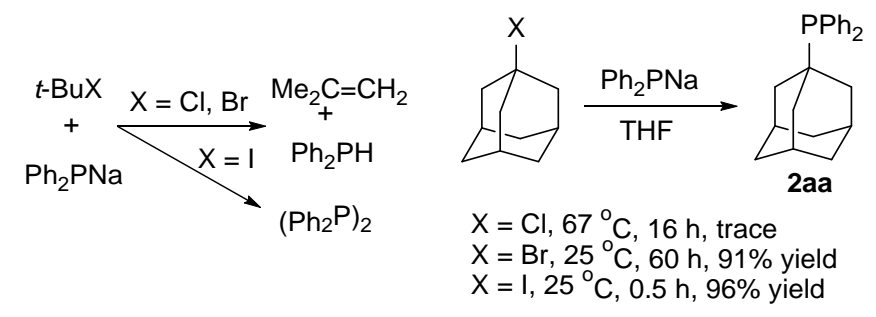

6-I: Reactions of $\mathbf{R}_{2} \mathrm{PNa}$ with tert-butyl halides.

Figure S44. 


$$
\begin{aligned}
& \mathrm{Ph}_{2} \mathrm{PNa}+t \text {-BuX } \underset{\mathrm{rt}}{\stackrel{\mathrm{THF}}{\longrightarrow}} \mathrm{Ph}_{2} \mathrm{PH} \text { or }\left(\mathrm{Ph}_{2} \mathrm{P}\right)_{2} \\
& 0.2 \mathrm{mmol} \quad 0.3 \mathrm{mmol} \\
& \mathrm{X}=\mathrm{Cl} \quad 95 \% \\
& \mathrm{Br} \quad 63 \% \\
& \text { I } 93 \%
\end{aligned}
$$

To a solution of $\mathrm{Ph}_{2} \mathrm{PNa}(0.21 \mathrm{mmol}$ in $0.6 \mathrm{~mL} \mathrm{THF}$ ), 2-chloro-2-methylpropane (34 $\mu \mathrm{L}, 0.3$ mmol) was added at room temperature or at $-30{ }^{\circ} \mathrm{C}$, and the reaction mixture was analyzed by ${ }^{31} \mathrm{P}$ NMR, $\mathrm{Ph}_{2} \mathrm{PH} \delta=-39.98$ was generated and the desired coupling product could not be observed.

Figure S45: at room temperature

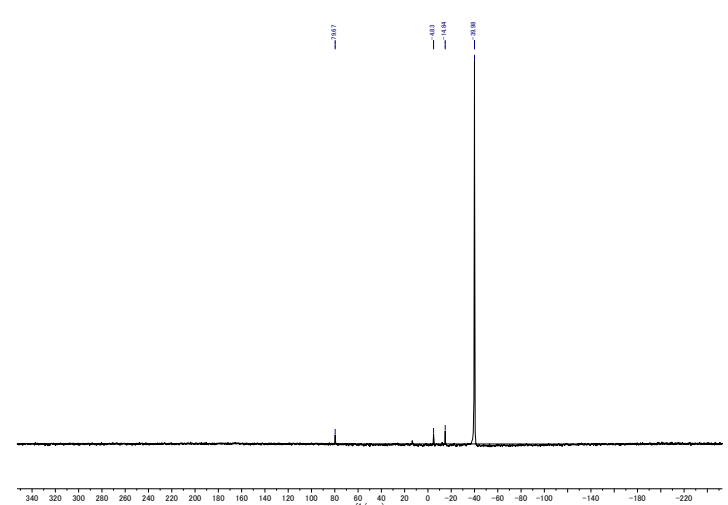

Figure S46: at $-30^{\circ} \mathrm{C}$

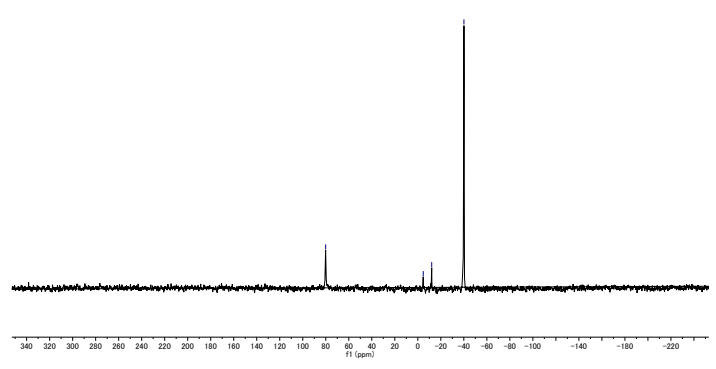

The reaction using $t-\mathrm{BuBr}$ gave a similar result

Figure S47: ${ }^{31} \mathrm{P}-\mathrm{NMR}$ using $\mathrm{t}-\mathrm{BuBr}$

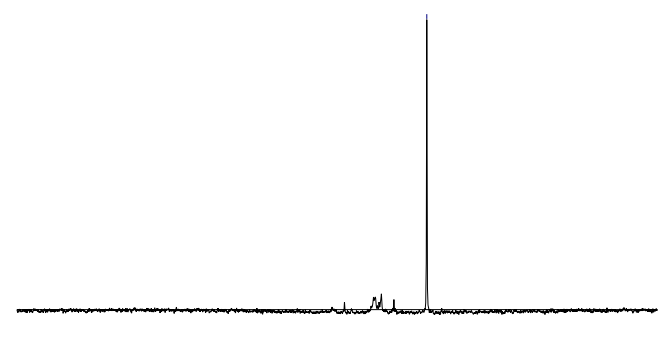

On the other hand, under similar conditions, $t$-BuI gave $\left(\mathrm{Ph}_{2} \mathrm{P}\right)_{2}$. 
Figure S48: ${ }^{31} \mathrm{P}-\mathrm{NMR}$ spectrum using t-BuI

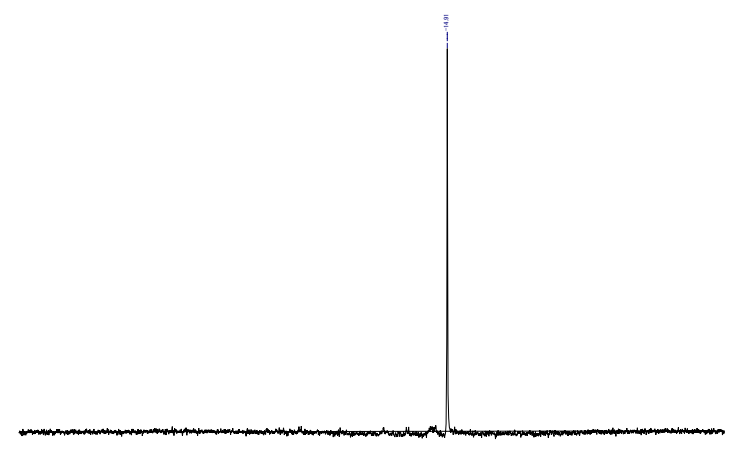

6-II: Reactions of $\mathrm{R}_{2} \mathrm{PNa}$ with 1-adamantyl halides.

Figure S49.

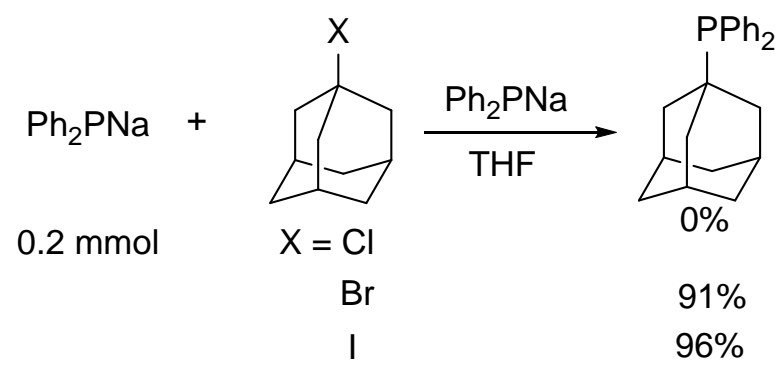

1-Chloroadamantane: To a THF solution of $\mathrm{Ph}_{2} \mathrm{PNa}(0.21 \mathrm{mmol}$ in $0.6 \mathrm{~mL}$ THF), 1-chloroadamantane $(51.2 \mathrm{mg}, 0.3 \mathrm{mmol})$ was added at room temperature. Only a trace product was observed after $16 \mathrm{~h}$ at $67^{\circ} \mathrm{C}$.

Figure S50: 0.5 hour

Figure S51: 16 hours 

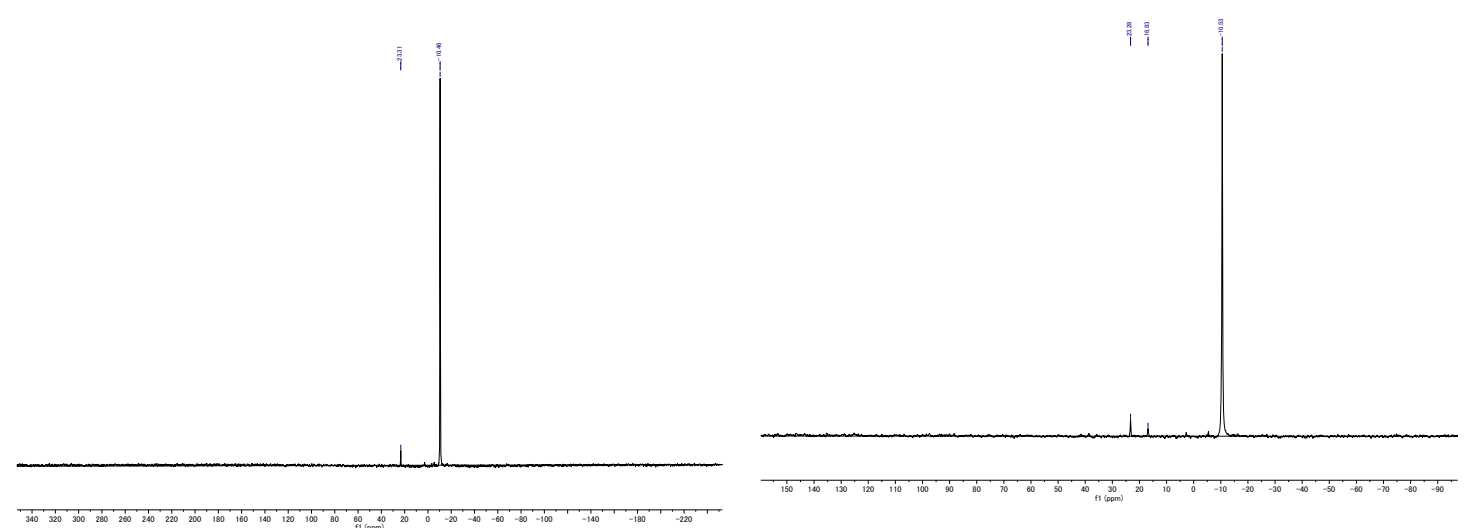

1- Bromoadamantane: Similarly, 1-bromoadmantane ( $64.5 \mathrm{mg}, 0.3 \mathrm{mmol})$ was allowed to react with $\mathrm{Ph}_{2} \mathrm{PNa}$ at room temperature. $91 \%$ of the product was obtained after 60 hours.

2-

Figure S52: $25^{\circ} \mathrm{C}, 16$ hours

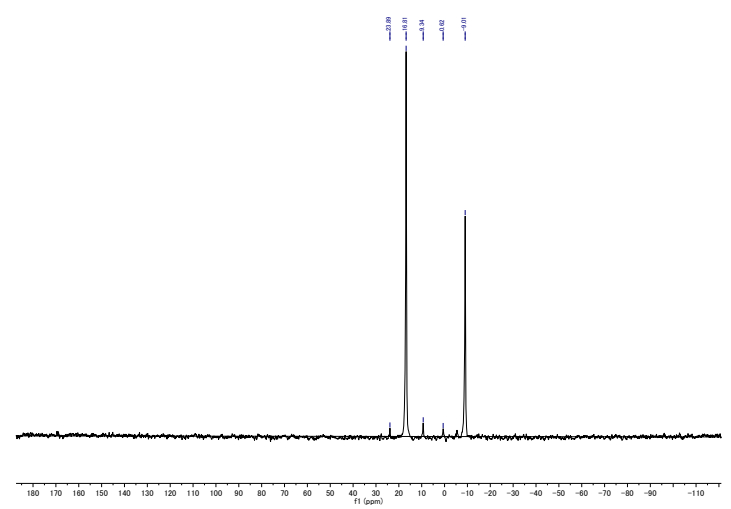

Figure S53: $25^{\circ} \mathrm{C}, 60$ hours

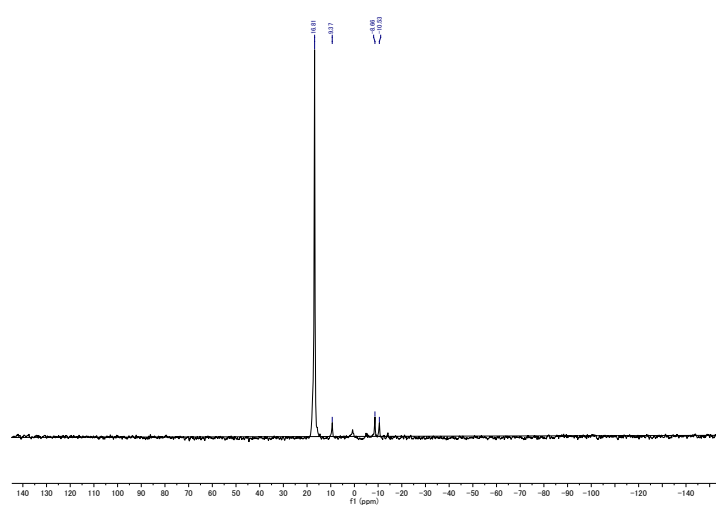

1-Iodoadamantane: 1-iodoadmantane (78.6 mg, $0.3 \mathrm{mmol}$ ) reacted with $\mathrm{Ph}_{2} \mathrm{PNa}$ at room temperature, after stirred for 0.5 hour the reaction mixture was analyzed by ${ }^{31} \mathrm{P}$ NMR. ${ }^{31} \mathrm{P}$ NMR of (1-adamantyl)diphenylphosphine, $\delta=16.78$ (96\% purity).

Figure S54: $25^{\circ} \mathrm{C}, 0.5 \mathrm{~h}$

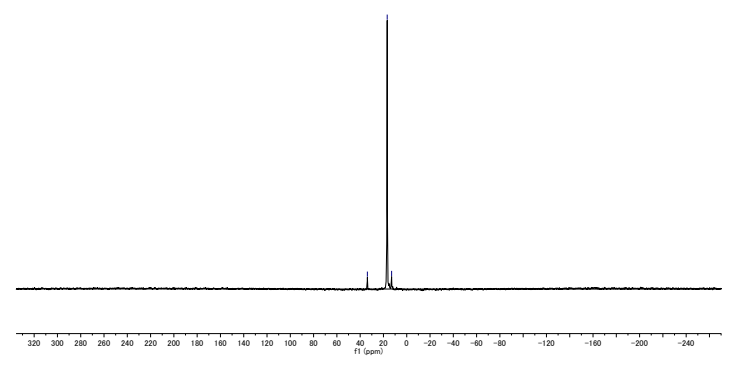


Part 7. The preparation of $R^{1} R^{2} P A r$ from $R^{1} R^{2} P N a$ and aryl halides.

Figure S55.

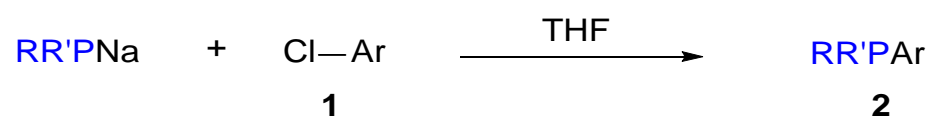

Reaction procedure: the reactions were similarly (like Part 5) carried out except $\mathrm{Ph}_{2} \mathrm{PNa}$ was replaced by PhMePNa (0.4 mol/L THF solution).

Figure S56: Synthesis of phosphinopolymers.

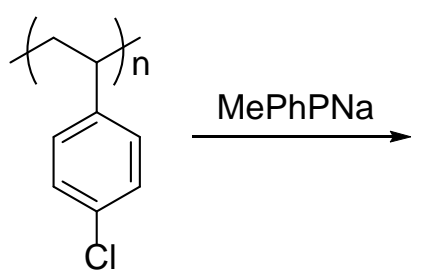

$0.2 \mathrm{mmol}$<smiles>CCCC(c1ccc(Pc2ccccc2)cc1)C(C)(C)C</smiles>

2ak, 98\% yield

(d)

Under nitrogen atmosphere, to the solution of PhMePNa (0.3 mmol) and 15-crown 5-ether (50 $\mu \mathrm{L}$, $0.25 \mathrm{mmol})$, poly(4-chlorostyrene) $(0.2 \mathrm{mmol})$ was added at room temperature and stirred for 3 hours. Volatiles were removed under vacuum and the polymer was washed with water and then EtOAc and dried under vaccum.

Figure S57: ${ }^{31}$ P-NMR spectrum of $2 a k$ 


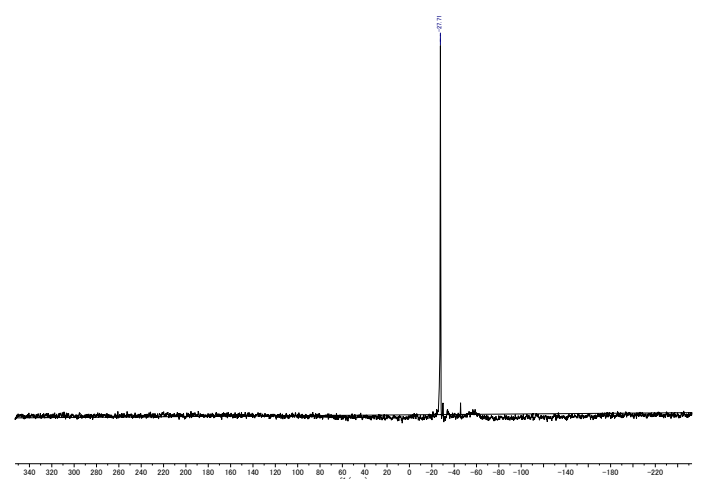

Part 8. One-pot synthesis of an unsymmetric phosphine.

Figure S58.

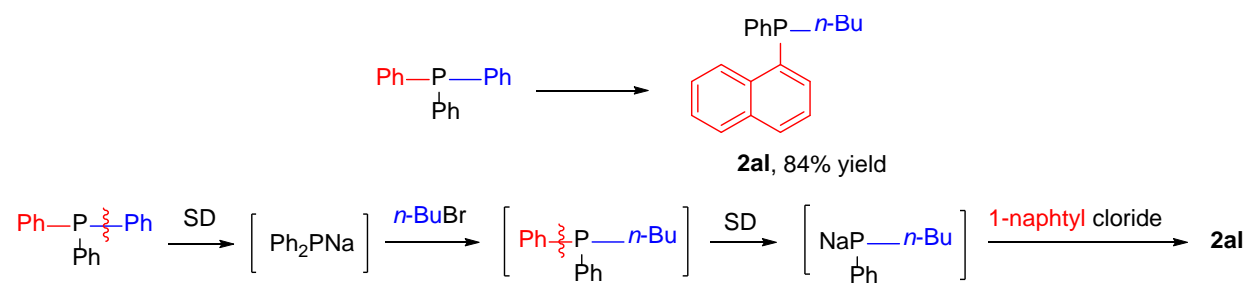

Under nitrogen atmosphere, $\mathrm{Ph}_{3} \mathrm{P}(1.05 \mathrm{~g}, 4 \mathrm{mmol})$ in THF $(8 \mathrm{~mL})$ was cooled in an ice-water bath. Then SD $(0.8 \mathrm{~mL}, 8 \mathrm{mmol}, 10 \mathrm{~mol} / \mathrm{L})$ was added. The mixture was stirred for $0.5 \mathrm{~h}$ cleanly generated $\mathrm{Ph}_{2} \mathrm{PNa}$.

Figure S59: ${ }^{31} \mathrm{P}-\mathrm{NMR}$ of $\mathrm{Ph}_{2} \mathrm{PNa}$

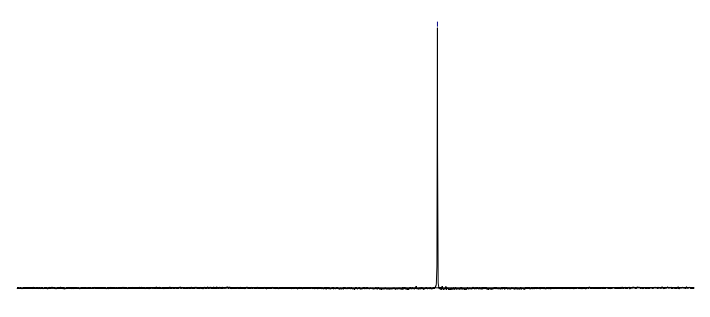

$n$ - $\mathrm{BuBr}(0.44 \mathrm{~mL}, 4.1 \mathrm{mmol})$ was added to the mixture and the mixture was stirred for 0.5 hour to almost quantitatively produce $n-\mathrm{BuPh}_{2} \mathrm{P}$.

Figure S60: ${ }^{31} \mathrm{P}-\mathrm{NMR}$ spectrum $\left(\mathrm{n}-\mathrm{BuPh} \mathrm{h}_{2} \mathrm{P}\right)$ 


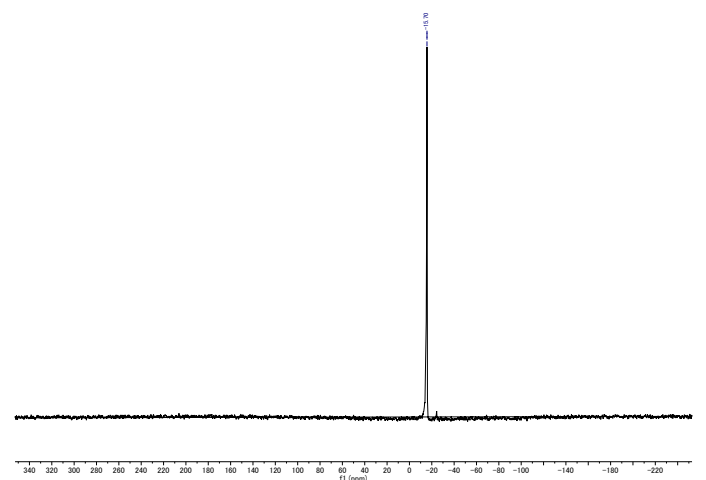

At room temperature, SD $(8.2 \mathrm{mmol})$ was added to the above mixture. Then the mixture was heated at $60{ }^{\circ} \mathrm{C}$ for 16 hours, generating $n$-BuPhPNa.

Figure S61: ${ }^{31} \mathrm{P}-\mathrm{NMR}$ spectrum of $\mathrm{n}-\mathrm{BuPhPNa}$

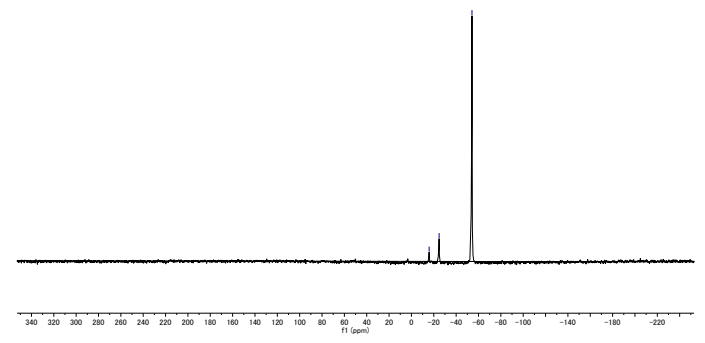

To the above solution, were added 15-crown 5-ether $(0.99 \mathrm{~mL}, 5 \mathrm{mmol})$ and 1-chloronaphthalene (0.61 mL, $4.5 \mathrm{mmol}$ ) at room temperature, and the mixture was stirred for 8 hours. Saturated ammonium chloride aqua solution $(15 \mathrm{~mL})$ was added, and the mixture was extracted with ethyl acetate $(50 \mathrm{~mL})$, washed with water $(3 \times 10 \mathrm{~mL})$, dried over magnesium sulfate. After removing 
solvent, the residue was purified with column chromatography on silica gel (ethyl acetate/hexane $=1 / 10)$ to afford pure 1-napBuPhP (0.99 g, 84\% yield) as a colorless oil.

Figure S62: ${ }^{31} \mathrm{P}-\mathrm{NMR}$ spectrum of the crude 1-napBuPhP after the reaction

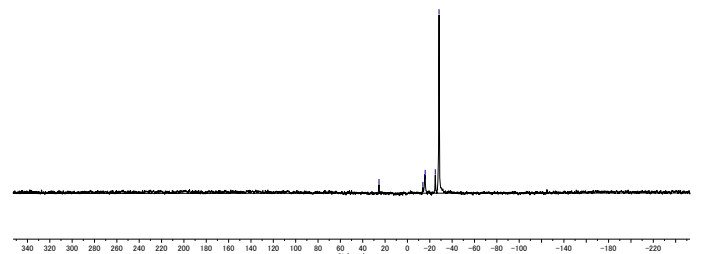

Part 9. Synthesis of chiral phosphines using sodium phosphides.

\section{Figure S63.}

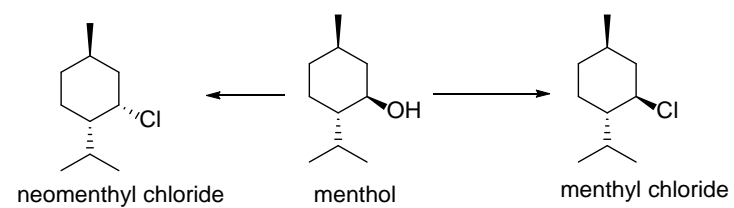

(-)-Menthyl chloride and (+)-neomenthyl chloride were prepared according to literatures. ${ }^{1,2}$

(1) Hidai, M.; Mizuta, H.; Yagi, H.; Nagai, Y.; Hata, K.; Uchida, Y. Palladium-Catalyzed Asymmetric Telomerization of Isoprene. Preparation of Optically Active Citronellol. J. Organomet. Chem. 1982, 232, 89-98.

(2) Hintermann, L.; Wong, K. M. Rearrangement in Stereoretentive Syntheses of Menthyl Chloride from Menthol: Insight into Competing Reaction Pathways through Component Quantification Analysis. Eur. J. Org. Chem. 2017, 37, 5527-5536.

Table 5: Reaction of neomenthyl chloride with $\mathrm{Ph}_{2} \mathrm{PNa}$ under different conditions. ${ }^{a}$ 


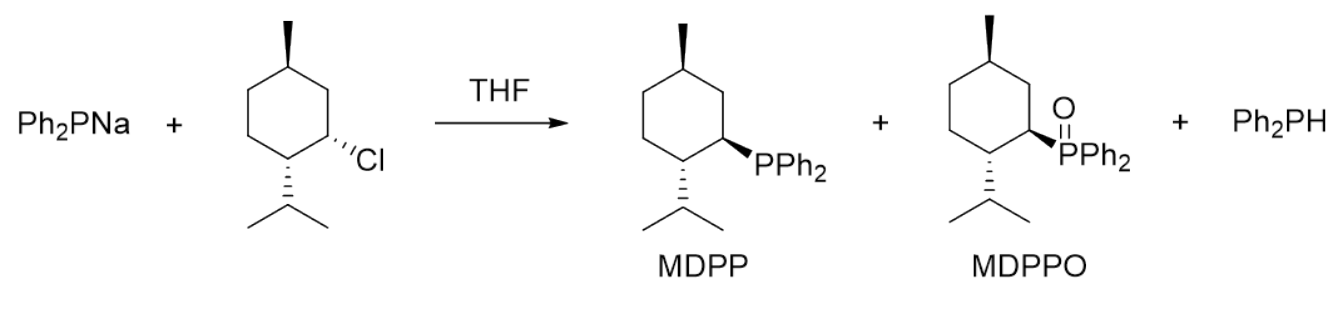

\begin{tabular}{cccccc}
\hline run & temp. $\left({ }^{\circ} \mathrm{C}\right)$ & time $(\mathrm{h})$ & additive & $\begin{array}{r}\% \text { yield MDPP } \\
\text { (MDPPO) }\end{array}$ & \% yield PhPH \\
\hline 1 & $\mathrm{rt}$ & 2 & none & 36 & 44 \\
2 & 67 & 16 & none & $23(20)$ & 44 \\
3 & $\mathrm{rt}$ & 2 & HMPA & $39(16)$ & 41 \\
4 & 67 & 16 & HMPA & 52 & 20 \\
5 & $\mathrm{rt}$ & 1 & 18-crown-6 & 52 & 25 \\
6 & $\mathrm{rt}$ & 1 & 15-crown-5 & 54 & 18 \\
7 & $\mathrm{rt}$ & 1 & DMF & 59 & 20 \\
\hline
\end{tabular}

${ }^{a}$ Reaction conditions: neomenthyl chloride $(0.3 \mathrm{mmol})$ was added to a mixture of $\mathrm{Ph}_{2} \mathrm{PNa}(0.21 \mathrm{mmol}$ in $0.6 \mathrm{~mL}$ THF) and an additive $(0.25 \mathrm{mmol})$ under argon. Yields refer to NMR yields determined by ${ }^{31} \mathrm{P}$ NMR.

Thus, the preferred conditions for this reaction are run 6 and run 7.

run 6: Under nitrogen, to a THF solution of $\mathrm{Ph}_{2} \mathrm{PNa}(0.21 \mathrm{mmol}$ in $0.6 \mathrm{~mL}$ THF) and 15-crown 5-ether (50 $\mu \mathrm{L}, 0.25 \mathrm{mmol}$ ), neomenthyl chloride (56 $\mu \mathrm{L}, 0.3 \mathrm{mmol}$ ) was added at room temperature, and stirred for 1 hour.

run 7: Under nitrogen, to $\mathrm{Ph}_{2} \mathrm{PNa} \quad(0.21 \mathrm{mmol}$ in $0.6 \mathrm{~mL}$ THF $)$ was added $N, N$-dimethyl-formamide (DMF) $(0.6 \mathrm{~mL})$ and neomenthyl chloride (56 $\mu \mathrm{L}, 0.3 \mathrm{mmol})$, and stirred for 1 hour.

Figure S64: ${ }^{31}$ P-NMR for run 6

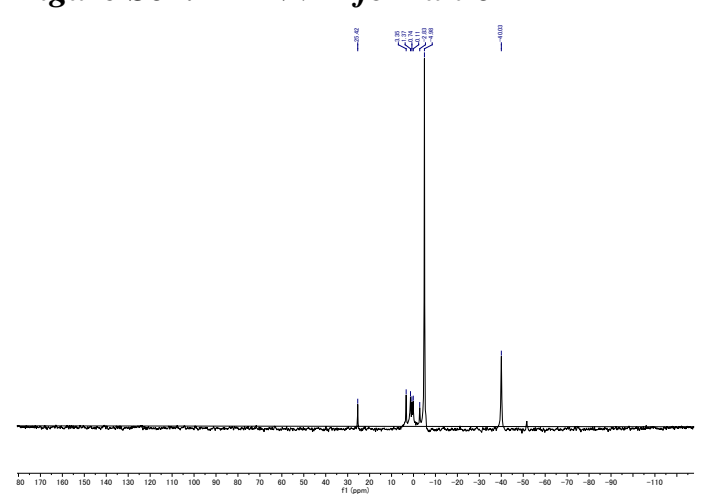

Table 6: Reactions of menthyl chloride and $\mathrm{Ph}_{2} \mathrm{PNa}$ under different conditions. ${ }^{a}$ 


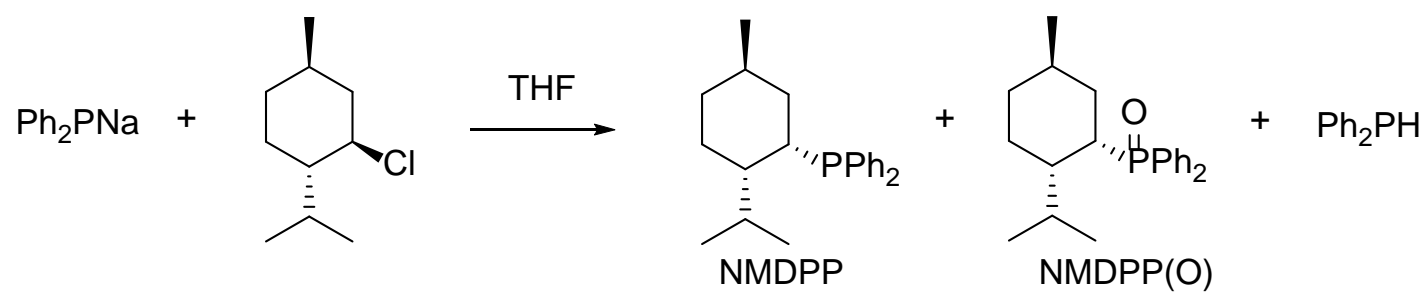

\begin{tabular}{cccccc}
\hline run & temp. $\left({ }^{\circ} \mathrm{C}\right)$ & time $(\mathrm{h})$ & additive & \% yield NMDPP & $\%$ yield $\mathrm{Ph}_{2} \mathrm{PH}$ \\
\hline 1 & 50 & 16 & none & 15 & 53 \\
2 & 67 & 16 & none & 58 & 13 \\
3 & 67 & 16 & HMPA & $60(10)^{b}$ & 8 \\
4 & 67 & 16 & HMPA & $66(24)^{b}$ & 5 \\
5 & 67 & 16 & 18-crown-6 & 69 & 0 \\
6 & 67 & 16 & 15-crown-5 & 69 & 0 \\
7 & 67 & 6 & DMF & 61 & 0 \\
\hline
\end{tabular}

Reaction conditions: menthyl chloride $(0.3 \mathrm{mmol})$ was added to a mixture of $\mathrm{Ph}_{2} \mathrm{PNa}(0.21 \mathrm{mmol}$ in $0.6 \mathrm{~mL}$ THF $)$ and an additive $(0.25 \mathrm{mmol})$. Yields refer to NMR yields determined by ${ }^{31} \mathrm{P}$ NMR spectroscopy. ${ }^{b}$ The yield of the oxide $\operatorname{NMDPP}(\mathrm{O})$.

Therefore, the best condition is run 6: to a solution of $\mathrm{Ph}_{2} \mathrm{PNa}$ and 15-crown 5-ether, was added menthyl chloride (56 $\mu \mathrm{L}, 0.3 \mathrm{mmol}$ ) at room temperature. The mixture was heated at $67{ }^{\circ} \mathrm{C}$ for 16 hours. Saturated aqua solution of ammonium chloride $(3 \mathrm{~mL})$ was added, and the mixture was extracted with ethyl acetate $(10 \mathrm{~mL})$, washed with water $(3 \times 5 \mathrm{~mL})$, dried over magnesium sulfate. After removing volatiles, the residues were purified using column chromatography on silica gel (ethyl acetate/hexane $=1 / 10$ ) to get pure NMDPP.

Figure S65: ${ }^{31}$ P-NMR for the mixture of run 6

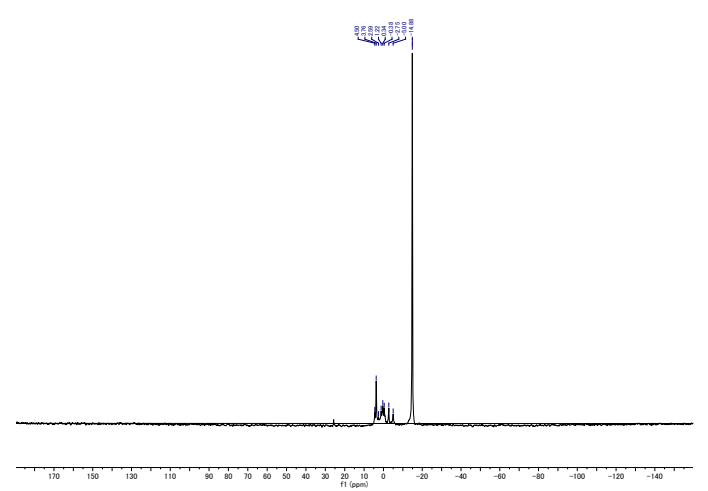




\section{Part 10. List of spectra data of the products.}<smiles>Pc1ccccc1</smiles>

Triphenylphosphine (2a). White solid: $48.5 \mathrm{mg}$, 88\% yield. ${ }^{31} \mathrm{P}$ NMR (162 $\left.\mathrm{MHz}, \mathrm{CDCl}_{3}\right) \delta=$ $-4.77 ;{ }^{1} \mathrm{H}$ NMR $\left(400 \mathrm{MHz}, \mathrm{CDCl}_{3}\right) \delta=7.36-7.35$ (m, 15H). This compound is known. ${ }^{1}$

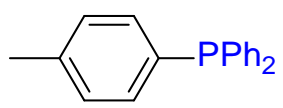

Diphenyl(4-tolyl)phosphine (2b). White solid: $41.7 \mathrm{mg}$, 88\% yield. ${ }^{31} \mathrm{P}$ NMR (162 MHz, $\mathrm{CDCl}_{3}$ ) $\delta=-5.58 ;{ }^{1} \mathrm{H}$ NMR $\left(400 \mathrm{MHz}, \mathrm{CDCl}_{3}\right) \delta=7.32-7.27$ (m, 10H), 7.21 (dd, $J=14.4,6.6 \mathrm{~Hz}, 2 \mathrm{H}$ ), 7.14 (d, $J=7.3 \mathrm{~Hz}, 2 \mathrm{H}), 2.34$ (s, 3H); ${ }^{13} \mathrm{C}$ NMR $\left(101 \mathrm{MHz}, \mathrm{CDCl}_{3}\right) \delta=138.93(\mathrm{~s}), 137.64$ (d, $J=$ $10.7 \mathrm{~Hz}$ ), 134.01 (d, $J=19.9 \mathrm{~Hz}), 133.79$ (s), 133.60 (s), 129.44 (d, $J=7.3 \mathrm{~Hz}), 128.65$ (s), 128.52 (d, $J=6.8 \mathrm{~Hz}$ ), 21.41 (s). This compound is known. ${ }^{1}$<smiles>CCCCc1ccc(P(c2ccccc2)c2ccc(CC(C)C)cc2)cc1</smiles>

(4-n-Butylphenyl)diphenylphosphine (2c). White solid: $50.8 \mathrm{mg}, 76 \%$ yield. ${ }^{31} \mathrm{P}$ NMR (162 MHz, $\left.\mathrm{CDCl}_{3}\right) \delta=-5.61(\mathrm{~s}) ;{ }^{1} \mathrm{H}$ NMR $\left(400 \mathrm{MHz}, \mathrm{CDCl}_{3}\right) \delta=7.34-7.30(\mathrm{~m}, 10 \mathrm{H}), 7.23$ (dd, $J=9.8,4.0$ Hz, 2H), 7.16 (d, $J=7.5$ Hz, 2H), $2.64-2.58$ (m, 2H), $1.65-1.55$ (m, 2H), 1.36 (dd, $J=14.9$, $7.4 \mathrm{~Hz}, 2 \mathrm{H}), 0.93(\mathrm{t}, J=7.4 \mathrm{~Hz}, 3 \mathrm{H}) ;{ }^{13} \mathrm{C}$ NMR $\left(101 \mathrm{MHz}, \mathrm{CDCl}_{3}\right) \delta=143.88$ (s), 137.69 (d, $J=$ $10.8 \mathrm{~Hz}$ ), 134.04 (s), 133.84 (s), 133.64 (s), 128.78 (d, $J=7.1 \mathrm{~Hz}$ ), 128.65 (s), 128.52 (d, $J=6.8$ Hz),35.57 (s), 33.54 (s), 22.50 (s), 14.06 (s). This compound is known. ${ }^{2}$<smiles>CC(C)(C)c1ccc(P(c2ccccc2)c2ccc(C(C)(C)C)cc2)cc1</smiles>

(4-tert-Butylphenyl)diphenylphosphine (2d). White solid: $58.1 \mathrm{mg}$, 87\% yield. ${ }^{31} \mathrm{P}$ NMR (162 $\left.\mathrm{MHz}^{\mathrm{CDCl}} \mathrm{CD}_{3}\right) \delta=-5.86(\mathrm{~s}) ;{ }^{1} \mathrm{H} \mathrm{NMR}\left(400 \mathrm{MHz}, \mathrm{CDCl}_{3}\right) \delta=7.36(\mathrm{t}, J=1.5 \mathrm{~Hz}, 1 \mathrm{H}), 7.34(\mathrm{t}, J=$ $1.7 \mathrm{~Hz}, 1 \mathrm{H}), 7.33-7.29$ (m, 10H), 7.25 (s, 1H), 7.23 (d, $J=8.1 \mathrm{~Hz}, 1 \mathrm{H}), 1.31$ (s, 9H); ${ }^{13} \mathrm{C}$ NMR (101 MHz, $\left.\mathrm{CDCl}_{3}\right) \delta=151.96$ (s), 137.65 (d, $J=10.5 \mathrm{~Hz}$ ), 133.86 (s), 133.68 (d, $J=19.0 \mathrm{~Hz}$ ), 133.67 (s), 128.65 (s), 128.50 (d, $J=7.0 \mathrm{~Hz}$ ), 125.62 (d, $J=7.3 \mathrm{~Hz}$ ), 34.74 (s), 31.33 (s). This compound is known. ${ }^{3}$ 
$\mathrm{PhCH}_{2} \longrightarrow \mathrm{PPh}_{2}$

(4-Benzylphenyl)diphenylphosphine (2e). waxy compound: $67.3 \mathrm{mg}$, 91\% yield. ${ }^{31} \mathrm{P}$ NMR (162 $\left.\mathrm{MHz}, \mathrm{CDCl}_{3}\right) \delta=-5.51(\mathrm{~s}) ;{ }^{1} \mathrm{H}$ NMR $\left(400 \mathrm{MHz}, \mathrm{CDCl}_{3}\right) \delta=7.34-7.28(\mathrm{~m}, 10 \mathrm{H}), 7.27(\mathrm{~s}, 1 \mathrm{H})$, 7.24 (d, $J=8.6 \mathrm{~Hz}, 2 \mathrm{H}), 7.21$ (d, $J=1.8 \mathrm{~Hz}, 1 \mathrm{H}), 7.20$ (s, 2H), 7.17 (d, $J=4.9 \mathrm{~Hz}, 2 \mathrm{H}), 7.15$ (s, 1H), 3.97 (s, 2H); ${ }^{13} \mathrm{C}$ NMR (101 MHz, $\left.\mathrm{CDCl}_{3}\right) \delta=142.00$ (s), 140.70 (s), 137.47 (d, $J=10.7 \mathrm{~Hz}$ ), 134.08 (d, $J=19.8 \mathrm{~Hz}), 133.85$ (s), 133.66 (s), 129.17 (d, $J=7.3 \mathrm{~Hz}), 129.09$ (s), 128.72 (s), 128.57 (s), 128.50 (s), 126.29 (s), 41.83 (s). HRMS (ESI ${ }^{+}$) Calcd. for $\mathrm{C}_{25} \mathrm{H}_{22} \mathrm{P}\left[\mathrm{M}+\mathrm{H}^{+}\right]$: 353.1459, Found: 353.1450 .<smiles>CC(C)(C)Oc1ccc(P(c2ccccc2)c2ccc(OC(C)(C)C)cc2)cc1</smiles>

(4-tert-Butoxyphenyl)diphenylphosphine (2f). White solid: $54.1 \mathrm{mg}, 77 \%$ yield. ${ }^{31} \mathrm{P}$ NMR (162 $\left.\mathrm{MHz}, \mathrm{CDCl}_{3}\right) \delta=-6.07(\mathrm{~s}) ;{ }^{1} \mathrm{H} \mathrm{NMR}\left(400 \mathrm{MHz}, \mathrm{CDCl}_{3}\right) \delta=7.32(\mathrm{dt}, J=5.0,2.7 \mathrm{~Hz}, 7 \mathrm{H}), 7.28$ (dd, $J=5.5,2.8 \mathrm{~Hz}, 3 \mathrm{H}), 7.24$ (d, $J=9.0 \mathrm{~Hz}, 1 \mathrm{H}), 7.20$ (d, $J=7.9 \mathrm{~Hz}, 1 \mathrm{H}$ ), 6.96 (d, $J=8.1 \mathrm{~Hz}$, 2H), 1.36 (s, 9H); ${ }^{13} \mathrm{C}$ NMR (101 MHz, $\left.\mathrm{CDCl}_{3}\right) \delta=156.51$ (s), 137.78 (d, $\left.J=10.6 \mathrm{~Hz}\right), 134.80$ (d, $J=20.6 \mathrm{~Hz}$ ), 133.76 (s), 133.57 (s), 128.64 (s), 128.52 (d, $J=6.9 \mathrm{~Hz}), 123.84$ (d, $J=7.7 \mathrm{~Hz}$ ), 78.88 (s), 29.00 (s). This compound is known. ${ }^{4}$

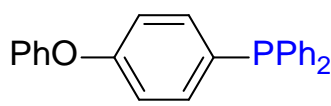

Diphenyl(4-phenoxyphenyl)phosphine (2g). waxy compound: $52.5 \mathrm{mg}, 71 \%$ yield. ${ }^{31} \mathrm{P}$ NMR $\left(162 \mathrm{MHz}, \mathrm{CDCl}_{3}\right) \delta=-4.48(\mathrm{~s}) ;{ }^{1} \mathrm{H}$ NMR $\left(400 \mathrm{MHz}, \mathrm{CDCl}_{3}\right) \delta=7.64(\mathrm{dt}, J=15.4,7.2 \mathrm{~Hz}, 8 \mathrm{H})$, 7.46 (dd, $J=9.9,4.2 \mathrm{~Hz}, 2 \mathrm{H}), 7.38-7.34$ (m, 4H), 7.32 (d, $J=8.1 \mathrm{~Hz}, 2 \mathrm{H}), 7.23$ (d, $J=5.2 \mathrm{~Hz}$, 3H); ${ }^{13} \mathrm{C}$ NMR (101 MHz, $\left.\mathrm{CDCl}_{3}\right) \delta=195.42$ (s), 138.84 (s), 137.20 (s), 135.83 (s), 133.95 (d, $J=$ $20.1 \mathrm{~Hz}$ ), 132.59 (s), 131.41 (s), 130.00 (s), 129.88 (s), 128.70 (s), 128.59 (s), 128.36 (s), 128.25 (s). This compound is known. ${ }^{5}$<smiles>CC(=O)c1ccc(-c2ccccc2)cc1</smiles>

Methyl (4-diphenylphosphino)benzoic acid (2h). White solid: $49.0 \mathrm{mg}, 73 \%$ yield. ${ }^{31} \mathrm{P}$ NMR (162 MHz, $\left.\mathrm{CDCl}_{3}\right) \delta=-4.51(\mathrm{~s}) ;{ }^{1} \mathrm{H}$ NMR $\left(400 \mathrm{MHz}, \mathrm{CDCl}_{3}\right) \delta=7.97$ (d, $\left.J=8.2 \mathrm{~Hz}, 2 \mathrm{H}\right), 7.42$ (d, $J=$ $1.3 \mathrm{~Hz}, 1 \mathrm{H}$ ), 7.39 (d, $J=1.0 \mathrm{~Hz}, 1 \mathrm{H}), 7.35$ (s, 8H), 7.33 (d, $J=1.8 \mathrm{~Hz}, 2 \mathrm{H}$ ), 3.90 (d, $J=1.2 \mathrm{~Hz}$, 
3H); ${ }^{13} \mathrm{C}$ NMR (101 MHz, CDCl $) \delta=166.62$ (d, $\left.J=65.4 \mathrm{~Hz}\right), 136.29$ (d, $\left.J=10.6 \mathrm{~Hz}\right), 134.06$ (d, $J=19.9 \mathrm{~Hz}$ ), 133.27 (d, $J=18.8 \mathrm{~Hz}), 131.08$ (s), 129.40 (d, $J=6.5 \mathrm{~Hz}), 129.24$ (s), 128.82 (s), 128.75 (s), 52.25 (s). This compound is known. ${ }^{1}$<smiles>FC(F)(F)c1ccc(P(c2ccccc2)c2ccccc2)cc1</smiles>

Dipheny(4-trifluoromethylphenyl)Iphosphine (2i). Pale yellow solid: $63.8 \mathrm{mg}, 92 \%$ yield. ${ }^{31} \mathrm{P}$ $\operatorname{NMR}\left(162 \mathrm{MHz}, \mathrm{CDCl}_{3}\right) \delta=-4.71(\mathrm{~s}) ;{ }^{1} \mathrm{H} \operatorname{NMR}\left(400 \mathrm{MHz}, \mathrm{CDCl}_{3}\right) \delta=7.46(\mathrm{t}, J=7.1 \mathrm{~Hz}, 2 \mathrm{H})$, 7.31 (s, 1H), 7.29 (s, 2H), 7.28 (d, $J=2.1 \mathrm{~Hz}, 2 \mathrm{H}), 7.27$ (d, $J=4.3 \mathrm{~Hz}, 3 \mathrm{H}), 7.25$ (d, $J=2.0 \mathrm{~Hz}$, 1H), $7.24-7.23(\mathrm{~m}, 2 \mathrm{H}), 7.22(\mathrm{dd}, J=2.8,1.7 \mathrm{~Hz}, 1 \mathrm{H}) ;{ }^{13} \mathrm{C} \mathrm{NMR}\left(101 \mathrm{MHz}, \mathrm{CDCl}_{3}\right) \delta=142.95$ (d, $J=14.5 \mathrm{~Hz}), 136.11$ (d, $J=10.5 \mathrm{~Hz}), 134.11$ (s), 133.92 (s), 133.65 (d, $J=19.1 \mathrm{~Hz}$ ), 129.32 (s), 128.84 (d, $J=7.4 \mathrm{~Hz}), 125.53$ (s), 125.36 - 125.03 (m), 124.18 (d, $J=270 \mathrm{~Hz}$ ). 122.83 (s). This compound is known. ${ }^{1}$<smiles>N#Cc1ccc(P(c2ccccc2)c2ccccc2)cc1</smiles>

(4-Diphenylphosphino)benzonitrile (2j). Colorless solid: 52.5 mg, 87\% yield. ${ }^{31} \mathrm{P}$ NMR (162 $\left.\mathrm{MHz}, \mathrm{CDCl}_{3}\right) \delta=-3.58(\mathrm{~s}) ;{ }^{1} \mathrm{H} \mathrm{NMR}\left(400 \mathrm{MHz}, \mathrm{CDCl}_{3}\right) \delta=7.57$ (t, $\left.J=1.5 \mathrm{~Hz}, 1 \mathrm{H}\right), 7.56-7.55$ (m, 1H), $7.41-7.36$ (m, 6H), 7.35 (dd, $J=3.8,2.1 \mathrm{~Hz}, 1 \mathrm{H}$ ), 7.33 (d, $J=1.4 \mathrm{~Hz}, 2 \mathrm{H}), 7.31$ (t, $J=$ $2.1 \mathrm{~Hz}, 2 \mathrm{H}), 7.30(\mathrm{dd}, J=2.5,1.6 \mathrm{~Hz}, 1 \mathrm{H}) ;{ }^{13} \mathrm{C}$ NMR $\left(101 \mathrm{MHz}, \mathrm{CDCl}_{3}\right) \delta=145.21(\mathrm{~d}, J=16.9$ Hz), 135.48 (d, $J=10.5 \mathrm{~Hz}$ ), 134.12 (d, $J=20.2 \mathrm{~Hz}$ ), 133.58 (d, $J=18.7 \mathrm{~Hz}$ ), 131.79 (d, $J=6.0$ Hz), 129.57 (s), 128.95 (d, $J=7.5 \mathrm{~Hz}), 118.79$ (s), 112.01 (s). This compound is known. ${ }^{1}$<smiles>Pc1cccc2ccccc12</smiles>

Diphenyl(1-naphthyl)phosphine (2k). White solid: $49.8 \mathrm{mg}, 76 \%$ yield. ${ }^{31} \mathrm{P}$ NMR (162 MHz, $\left.\mathrm{CDCl}_{3}\right) \delta=-13.54(\mathrm{~s}) ;{ }^{1} \mathrm{H}$ NMR $\left(400 \mathrm{MHz}, \mathrm{CDCl}_{3}\right) \delta=8.40(\mathrm{dd}, J=8.3,4.2 \mathrm{~Hz}, 1 \mathrm{H}), 7.85(\mathrm{t}, J$ $=9.0 \mathrm{~Hz}, 2 \mathrm{H}), 7.46$ (ddd, $J=11.0,9.5,4.0 \mathrm{~Hz}, 2 \mathrm{H}), 7.37-7.27(\mathrm{~m}, 11 \mathrm{H}), 7.03-6.96(\mathrm{~m}, 1 \mathrm{H})$; ${ }^{13} \mathrm{C}$ NMR (101 MHz, $\left.\mathrm{CDCl}_{3}\right) \delta=136.42$ (d, $\left.J=10.0 \mathrm{~Hz}\right), 135.38$ (d, $\left.J=22.0 \mathrm{~Hz}\right), 134.69$ (s), 134.37 (s), 134.18 (s), 133.51 (s), 132.11 (s), 129.54 (s), 128.92 (s), 128.70 (s), 128.63 (s), 126.38 (s), 126.09 (s), 125.67 (s). This compound is known. ${ }^{1}$ 
PPPh

Diphenyl(2-naphthyl)phosphine (2l). White solid: 52.5 mg, 80\% yield. ${ }^{31} \mathrm{P}$ NMR (162 MHz, $\left.\mathrm{CDCl}_{3}\right) \delta=-4.16(\mathrm{~s}) ;{ }^{1} \mathrm{H}$ NMR $\left(400 \mathrm{MHz}, \mathrm{CDCl}_{3}\right) \delta=7.83(\mathrm{t}, J=8.9 \mathrm{~Hz}, 3 \mathrm{H}), 7.76(\mathrm{~d}, J=8.2$ $\mathrm{Hz}, 1 \mathrm{H}), 7.54-7.46$ (m, 2H), $7.46-7.39$ (m, 3H), 7.38 (s, 8H); ${ }^{13} \mathrm{C} \mathrm{NMR}\left(101 \mathrm{MHz}, \mathrm{CDCl}_{3}\right) \delta=$ 137.23 (d, $J=10.7 \mathrm{~Hz}), 134.81$ (d, $J=11.2 \mathrm{~Hz}), 134.31$ (d, $J=22.5 \mathrm{~Hz}), 134.03$ (s), 133.83 (s), 133.41 (d, $J=13.4 \mathrm{~Hz}), 130.16$ (d, $J=17.3 \mathrm{~Hz}), 128.91$ (s), 128.67 (d, $J=6.8 \mathrm{~Hz}), 128.22$ (s), 128.08 (d, $J=6.5 \mathrm{~Hz}), 127.81$ (s), 126.82 (s), 126.40 (s). This compound is known. ${ }^{1}$<smiles>Pc1ccccn1</smiles>

(2-Diphenylphosphino)pyridine (2m). White solid: $48.1 \mathrm{mg}, 87 \%$ yield. ${ }^{31} \mathrm{P}$ NMR (162 MHz, $\left.\mathrm{CDCl}_{3}\right) \delta=-3.39(\mathrm{~s}) ;{ }^{1} \mathrm{H}$ NMR $\left(400 \mathrm{MHz}, \mathrm{CDCl}_{3}\right) \delta=8.75-8.70(\mathrm{~m}, 1 \mathrm{H}), 7.55$ (tt, $J=7.7,1.9$ Hz, 1H), 7.40 (ddd, $J$ = 9.3, 5.8, 2.2 Hz, 4H), 7.37 - 7.34 (m, 6H), 7.16 (ddt, $J$ = 7.7, 4.7, $1.0 \mathrm{~Hz}$, 1H), 7.09 (dd, $J=7.8,0.9 \mathrm{~Hz}, 1 \mathrm{H}) ;{ }^{13} \mathrm{C}$ NMR (101 MHz, CDCl 3 ) 164.10 (d, $J=4.3 \mathrm{~Hz}$ ), 150.42 (d, $J=12.6 \mathrm{~Hz}), 136.30$ (d, $J=10.9 \mathrm{~Hz}), 135.81$ (d, $J=1.6 \mathrm{~Hz}), 134.28$ (d, $J=19.8 \mathrm{~Hz}), 129.17$ (s), 128.72 (d, $J=7.0 \mathrm{~Hz}), 127.93$ (d, $J=15.5 \mathrm{~Hz}), 122.27$ (s). This compound is known. ${ }^{6}$<smiles>Clc1cccc(P(c2ccccc2)c2ccccc2)n1</smiles>

2-Chloro(6-diphenylphosphino)pyridine (2n). White solid: $53.1 \mathrm{mg}$, 85\% yield. ${ }^{31} \mathrm{P}$ NMR (162 $\left.\mathrm{MHz}, \mathrm{CDCl}_{3}\right) \delta=-2.62(\mathrm{~s}) ;{ }^{1} \mathrm{H} \mathrm{NMR}\left(400 \mathrm{MHz}, \mathrm{CDCl}_{3}\right) \delta=7.48(\mathrm{td}, J=7.8,1.8 \mathrm{~Hz}, 1 \mathrm{H}), 7.41-$ 7.34 (m, 10H), 7.19 (d, $J=8.0 \mathrm{~Hz}, 1 \mathrm{H}), 6.94$ (d, $J=7.6 \mathrm{~Hz}, 1 \mathrm{H}) ;{ }^{13} \mathrm{C}$ NMR (101 MHz, $\mathrm{CDCl}_{3}$ ) 165.56 (s), 151.92 (d, $J=12.6 \mathrm{~Hz}), 138.24$ (s), 135.60 (d, $J=10.6 \mathrm{~Hz}), 134.27$ (d, $J=20.1 \mathrm{~Hz}$ ), 129.37 (s), 128.78 (d, $J=7.4 \mathrm{~Hz}$ ), 126.41 (d, $J=13.4 \mathrm{~Hz}$ ), 123.01 (s). This compound is known. ${ }^{7}$ 
${ }_{\mathrm{Ph}} \mathrm{P} \overbrace{\mathrm{PPh}_{2}}$

(2,6-Bis-diphenylphosphino)pyridine (2o). White solid: $114.0 \mathrm{mg}$, 85\% yield. ${ }^{31} \mathrm{P}$ NMR (162 $\left.\mathrm{MHz}, \mathrm{CDCl}_{3}\right) \delta=-3.13(\mathrm{~s}) ;{ }^{1} \mathrm{H}$ NMR $\left(400 \mathrm{MHz}, \mathrm{CDCl}_{3}\right) \delta=7.72(\mathrm{dd}, J=11.2,7.8 \mathrm{~Hz}, 1 \mathrm{H}), 7.33$ (dd, $J=10.8,7.2 \mathrm{~Hz}, 11 \mathrm{H}), 7.29-7.24$ (m, 9H), 7.05 (d, $J=7.3 \mathrm{~Hz}, 2 \mathrm{H}) ;{ }^{13} \mathrm{C}$ NMR (101 MHz, $\left.\mathrm{CDCl}_{3}\right) \delta=164.53(\mathrm{~d}, J=9.3 \mathrm{~Hz}), 136.48$ (d, $\left.J=10.5 \mathrm{~Hz}\right), 135.22$ (s), 134.36 (d, $\left.J=19.7 \mathrm{~Hz}\right)$, 128.92 (s), 128.47 (d, $J=6.9 \mathrm{~Hz}), 126.79$ (d, $J=22.5 \mathrm{~Hz}$ ). This compound is known. ${ }^{7}$<smiles>Pc1cccs1</smiles>

Diphenyl(2-thienyl)phosphine (2p). Pale yellow solid: 25.0 mg, 44\% yield. ${ }^{31} \mathrm{P}$ NMR (162 MHz, $\left.\mathrm{CDCl}_{3}\right) \delta=-19.31$ (s); ${ }^{1} \mathrm{H}$ NMR $\left(400 \mathrm{MHz}, \mathrm{CDCl}_{3}\right) \delta=7.58$ (d, $\left.J=5.0 \mathrm{~Hz}, 1 \mathrm{H}\right), 7.37$ (dd, $J=6.5$, $3.7 \mathrm{~Hz}, 2 \mathrm{H}), 7.36-7.32$ (m, 7H), 7.30 (dd, $J=3.6,2.3 \mathrm{~Hz}, 1 \mathrm{H}), 7.12$ (dd, $J=4.8,3.7 \mathrm{~Hz}, 1 \mathrm{H}$ ); ${ }^{13} \mathrm{C}$ NMR (101 MHz, $\left.\mathrm{CDCl}_{3}\right) \delta=138.06$ (s), 136.42 (d, $\left.J=26.2 \mathrm{~Hz}\right), 133.17$ (d, $\left.J=19.6 \mathrm{~Hz}\right)$, 132.10 (s), 128.93 (s), 128.52 (d, $J=6.9 \mathrm{~Hz}), 128.11$ (d, $J=7.9 \mathrm{~Hz}$ ). This compound is known. ${ }^{1}$<smiles>Pc1cccs1</smiles>

(2,5-Bis-diphenylphosphino)thiophene (2q). Pale yellow solid: $30.1 \mathrm{mg}, 32 \%$ yield. ${ }^{31} \mathrm{P}$ NMR $\left(162 \mathrm{MHz}, \mathrm{CDCl}_{3}\right) \delta=-18.19$ (s); ${ }^{1} \mathrm{H}$ NMR $\left(400 \mathrm{MHz}, \mathrm{CDCl}_{3}\right) \delta=7.36-7.34$ (m, 4H), 7.32 (d, $J$ $=2.1 \mathrm{~Hz}, 13 \mathrm{H}), 7.25$ (d, $J=0.7 \mathrm{~Hz}, 4 \mathrm{H}), 7.20-7.16(\mathrm{~m}, 2 \mathrm{H}) ;{ }^{13} \mathrm{C} \mathrm{NMR}\left(101 \mathrm{MHz}, \mathrm{CDCl}_{3}\right) \delta=$ 137.54 (s), 133.36 (s), 133.16 (s), 129.04 (s), 128.59 (s), 128.52 (s). This compound is known. ${ }^{8}$<smiles>Pc1ccccc1Cl</smiles>

(2-Chlorophenyl)diphenylphosphine (2r). White solid: $24.2 \mathrm{mg}$, 39\% yield. ${ }^{31} \mathrm{P}$ NMR (162 MHz, $\left.\mathrm{CDCl}_{3}\right) \delta=-4.67(\mathrm{~s}) ;{ }^{1} \mathrm{H}$ NMR $\left(400 \mathrm{MHz}, \mathrm{CDCl}_{3}\right) \delta=7.30(\mathrm{~d}, J=0.8 \mathrm{~Hz}, 1 \mathrm{H}), 7.30-7.26(\mathrm{~m}$, 7H), $7.25-7.23$ (m, 3H), $7.23-7.21$ (m, 2H), 7.21 (s, 1H); ${ }^{13} \mathrm{C}$ NMR (101 MHz, $\left.\mathrm{CDCl}_{3}\right) \delta=$ 141.83 (d, $J=20.0 \mathrm{~Hz}), 138.86$ (s), 136.96 (d, $J=10.7 \mathrm{~Hz}$ ), 134.07 (d, $J=20.8 \mathrm{~Hz}), 133.83$ (s), 133.64 (s), 128.81 (s), 128.56 (d, $J=6.9 \mathrm{~Hz}$ ). This compound is known. ${ }^{1}$ 
<smiles>Pc1cccc(Cl)c1</smiles>

(3-Chlorophenyl)diphenylphosphine (2s). Colorless solid: 55.5 mg, 89\% yield. ${ }^{31} \mathrm{P}$ NMR (162 $\left.\mathrm{MHz}, \mathrm{CDCl}_{3}\right) \delta=-13.54(\mathrm{~s}) ;{ }^{1} \mathrm{H}$ NMR $\left(400 \mathrm{MHz}, \mathrm{CDCl}_{3}\right) \delta=7.39-7.33(\mathrm{~m}, 6 \mathrm{H}), 7.33-7.27(\mathrm{~m}$, 5H), 7.25 (d, $J=2.6 \mathrm{~Hz}, 1 \mathrm{H}), 7.24-7.21(\mathrm{~m}, 1 \mathrm{H}), 7.19-7.14(\mathrm{~m}, 1 \mathrm{H}) ;{ }^{13} \mathrm{C}$ NMR $(101 \mathrm{MHz}$, $\left.\mathrm{CDCl}_{3}\right) \delta=140.21$ (d, $\left.J=15.1 \mathrm{~Hz}\right), 136.38$ (d, $J=11.1 \mathrm{~Hz}$ ), 133.98 (s), 133.78 (s), 133.19 (d, $J=$ $19.6 \mathrm{~Hz}$ ), 131.76 (d, $J=19.9 \mathrm{~Hz}), 129.80$ (d, $J=6.9 \mathrm{~Hz}$ ), 129.15 (s), 128.88 (s), 128.75 (d, $J=7.0$ $\mathrm{Hz}$. This compound is known. ${ }^{1}$<smiles>Pc1cc(Cl)cc(Cl)c1</smiles>

(3,5-Dichlorophenyl)diphenylphosphine (2t). Colorless solid: $43.4 \mathrm{mg}, 63 \%$ yield. ${ }^{31} \mathrm{P}$ NMR (162 $\left.\mathrm{MHz}, \mathrm{CDCl}_{3}\right) \delta=-3.41(\mathrm{~s}) ;{ }^{1} \mathrm{H}$ NMR $\left(400 \mathrm{MHz}, \mathrm{CDCl}_{3}\right) \delta=7.40-7.36(\mathrm{~m}, 6 \mathrm{H}), 7.33(\mathrm{~d}, J=2.1$ Hz, 1H), 7.32 - 7.30 (m, 3H), 7.29 (d, $J=4.5 \mathrm{~Hz}, 1 \mathrm{H}), 7.12$ (d, $J=1.8 \mathrm{~Hz}, 1 \mathrm{H}), 7.11$ (d, $J=1.9$ $\mathrm{Hz}, 1 \mathrm{H}) ;{ }^{13} \mathrm{C} \mathrm{NMR}\left(101 \mathrm{MHz}, \mathrm{CDCl}_{3}\right) \delta=142.41$ (d, $\left.J=18.6 \mathrm{~Hz}\right), 135.43(\mathrm{dd}, J=22.7,9.1 \mathrm{~Hz}$ ), 134.06 (s), 133.86 (s), 131.33 (d, $J=19.9 \mathrm{~Hz}), 129.50$ (s), 128.93 (d, $J=7.4 \mathrm{~Hz}$ ), 128.75 (s). This compound is known. ${ }^{9}$<smiles>Pc1ccc(Pc2ccccc2)cc1</smiles>

(1,4-Bis-diphenylphosphino)benzene (2u). White solid: $113.3 \mathrm{mg}, 85 \%$ yield. ${ }^{31} \mathrm{P}$ NMR (162 $\left.\mathrm{MHz}, \mathrm{CDCl}_{3}\right) \delta=-5.05(\mathrm{~s}) ;{ }^{1} \mathrm{H}$ NMR $\left(400 \mathrm{MHz}, \mathrm{CDCl}_{3}\right) \delta=7.36-7.28(\mathrm{~m}, 20 \mathrm{H}), 7.26-7.21(\mathrm{~m}$, 4H); ${ }^{13} \mathrm{C}$ NMR (101 MHz, CDCl 3 ) $\delta=138.08$ (d, $\left.J=12.3 \mathrm{~Hz}\right), 136.87$ (d, $\left.J=11.0 \mathrm{~Hz}\right), 133.95$ (d, $J=20.0 \mathrm{~Hz}$ ), 133.48 (dd, $J=19.4,6.2 \mathrm{~Hz}$ ), 128.96 (s), 128.63 (d, $J=7.4 \mathrm{~Hz}$ ). This compound is known. ${ }^{2}$<smiles>C(=Cc1ccccc1)Pc1ccccc1</smiles>
trans-1,2-Bis-diphenylphosphinoethylene (2v). White solid: $67.7 \mathrm{mg}$, 81\% yield. ${ }^{31} \mathrm{P}$ NMR (162 $\left.\mathrm{MHz}, \mathrm{CDCl}_{3}\right) \delta=-6.97(\mathrm{~s}) ;{ }^{1} \mathrm{H} \mathrm{NMR}\left(400 \mathrm{MHz}, \mathrm{CDCl}_{3}\right) \delta=7.40-7.35(\mathrm{~m}, 7 \mathrm{H}), 7.35-7.29(\mathrm{~m}$, 13H), 6.73 (dd, $J=21.9,7.5 \mathrm{~Hz}, 2 \mathrm{H}) ;{ }^{13} \mathrm{C}$ NMR $\left(101 \mathrm{MHz}, \mathrm{CDCl}_{3}\right) \delta=142.45(\mathrm{t}, J=23.2 \mathrm{~Hz})$, 
137.22 (s), 133.79 - 133.10 (m), 128.97 (s), 128.79 - 128.55 (m). This compound is known. ${ }^{10}$

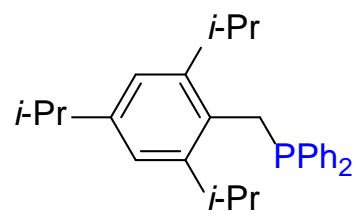

Diphenyl(2,4,6-triisopropylbenzyl)phosphine (2w). White solid: 77.8 mg, 92\% yield; m.p. 175.1

$-176.6{ }^{\circ} \mathrm{C} .{ }^{31} \mathrm{P}$ NMR $\left(162 \mathrm{MHz}, \mathrm{CDCl}_{3}\right) \delta=-10.65$ (s); ${ }^{1} \mathrm{H}$ NMR $\left(400 \mathrm{MHz}, \mathrm{CDCl}_{3}\right) \delta=7.61-$ 7.53 (m, 4H), 7.46 (d, $J=7.2 \mathrm{~Hz}, 2 \mathrm{H}), 7.41-7.34$ (m, 4H), 6.90 (s, 2H), 3.82 (d, $J=14.2 \mathrm{~Hz}, 2 \mathrm{H})$, 2.96 (s, 2H), 2.83 (dt, $J=13.7,6.9 \mathrm{~Hz}, 1 \mathrm{H}), 1.24-1.18(\mathrm{~m}, 6 \mathrm{H}), 0.97(\mathrm{~d}, J=6.7 \mathrm{~Hz}, 12 \mathrm{H}) ;{ }^{13} \mathrm{C}$ NMR (101 MHz, $\left.\mathrm{CDCl}_{3}\right) \delta=147.88$ (d, $\left.J=4.6 \mathrm{~Hz}\right), 147.65$ (d, $\left.J=3.3 \mathrm{~Hz}\right), 132.88(\mathrm{~d}, J=96.8$ Hz), 131.76 (d, $J=1.8 \mathrm{~Hz}), 131.48$ (d, $J=8.9 \mathrm{~Hz}), 128.42$ (d, $J=11.5 \mathrm{~Hz}), 122.99$ (d, $J=8.9$ Hz), 121.06 (d, $J=2.5 \mathrm{~Hz}$ ), 34.24 (s), 30.73 (d, $J=66.3 \mathrm{~Hz}$ ), 30.24 (s), 24.17 (s), 23.70 (s). Elemental Analysis: Calcd. for $\mathrm{C}_{28} \mathrm{H}_{35} \mathrm{P}$; C, 83.54; H, 8.76; Found: C, 83.84; H, 8.63. HRMS $\left(\mathrm{ESI}^{+}\right.$) Calcd. for $\mathrm{C}_{28} \mathrm{H}_{35} \mathrm{PNa}\left[\mathrm{M}+\mathrm{Na}^{+}\right]$: 425.2374, Found: 425.2364.

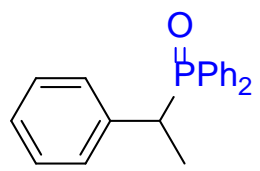

Diphenyl(1-phenylethylphosphine (2x). ${ }^{31} \mathrm{P}$ NMR (162 MHz, $\left.\mathrm{CDCl}_{3}\right) \delta=2.47$ (s).

Diphenyl(1-phenylethylphosphine oxide (4x). White solid: 77.8 mg, 92\% yield. ${ }^{31}$ P NMR (162 $\left.\mathrm{MHz}, \mathrm{CDCl}_{3}\right) \delta=34.24(\mathrm{~s}) ;{ }^{1} \mathrm{H}$ NMR $\left(400 \mathrm{MHz}, \mathrm{CDCl}_{3}\right) \delta=7.92-7.83(\mathrm{~m}, 2 \mathrm{H}), 7.56-7.47$ (m, 3H), $7.47-7.39(\mathrm{~m}, 2 \mathrm{H}), 7.33(\mathrm{dd}, J=10.4,4.4 \mathrm{~Hz}, 1 \mathrm{H}), 7.27-7.11(\mathrm{~m}, 7 \mathrm{H}), 3.64-3.53(\mathrm{~m}$, 1H), 1.57 (dd, $\left.J=16.2,7.3 \mathrm{~Hz}, 3 \mathrm{H}) ;{ }^{13} \mathrm{C} \mathrm{NMR} \mathrm{(101} \mathrm{MHz,} \mathrm{CDCl}_{3}\right) \delta=138.04-137.84(\mathrm{~m})$, 132.57 - 132.31 (m), 131.79 (s), 131.51 (s), 131.42 (s), 131.20 (d, $J=8.7 \mathrm{~Hz}), 129.27$ (d, $J=5.5$ Hz), 128.75 (d, $J=11.2 \mathrm{~Hz}), 128.33$ (s), 128.11 (d, $J=11.5 \mathrm{~Hz}), 126.97$ (s), 41.02 (d, $J=67.2$ Hz), 15.49 (s). This compound is known. ${ }^{11}$

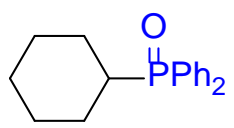

Cyclohexyldiphenylphosphane (2y). ${ }^{31} \mathrm{P}$ NMR (162 $\left.\mathbf{M H z}, \mathrm{CDCl}_{3}\right) \delta=-3.54$ (s). 
Cyclohexyldiphenylphosphine oxide (4y). Pale yellow solid: 43.6 mg, 73\% yield. ${ }^{31}$ P NMR (162 $\left.\mathrm{MHz}, \mathrm{CDCl}_{3}\right) \delta=35.13(\mathrm{~s}) ;{ }^{1} \mathrm{H}$ NMR $\left(400 \mathrm{MHz}, \mathrm{CDCl}_{3}\right) \delta=7.80-7.73(\mathrm{~m}, 3 \mathrm{H}), 7.52-7.41(\mathrm{~m}$, 5H), 7.25 (s, 1H), 7.25 (s, 1H), 2.28 - 2.15 (m, 1H), 1.79 (s, 2H), 1.71 (d, J = 12.6 Hz, 4H), 1.59 1.46 (m, 2H), 1.24 (d, $J=7.4 \mathrm{~Hz}, 2 \mathrm{H}) ;{ }^{13} \mathrm{C}$ NMR (101 MHz, $\left.\mathrm{CDCl}_{3}\right) \delta=132.64$ (s), 131.51 (d, $J$ = 2.0 Hz), 131.17 (d, $J=8.7 \mathrm{~Hz}), 128.62$ (d, $J=11.2 \mathrm{~Hz}), 37.30$ (d, $J=73.0 \mathrm{~Hz}), 26.47$ (d, $J=$ $13.3 \mathrm{~Hz}), 25.86$ (s), 24.86 (s). This compound is known. ${ }^{12}$<smiles>O=Pc1ccccc1</smiles>

(1-Adamantyl)diphenylphosphine (2aa). ${ }^{31} \mathrm{P}$ NMR (162 MHz, $\left.\mathbf{C D C l}_{3}\right) \delta=16.82$ (s).

(1-Adamantyl)diphenylphosphine oxide (4aa). White solid: $51.6 \mathrm{mg}, 73 \%$ yield. ${ }^{31} \mathrm{P}$ NMR (162 $\left.\mathrm{MHz}, \mathrm{CDCl}_{3}\right) \delta=34.31(\mathrm{~s}) ;{ }^{1} \mathrm{H}$ NMR $\left(400 \mathrm{MHz}, \mathrm{CDCl}_{3}\right) \delta=8.00-7.91$ (m, 4H), $7.54-7.43$ (m, 6H), 1.97 (s, 3H), 1.94 - 1.91 (m, 5H), 1.73 (d, $J=13.0 \mathrm{~Hz}, 2 \mathrm{H}), 1.67$ (d, $J$ = 8.7 Hz, 4H), 1.63 (s, 1H); ${ }^{13} \mathrm{C}$ NMR (101 MHz, $\left.\mathrm{CDCl}_{3}\right) \delta=132.25$ (d, $\left.J=7.8 \mathrm{~Hz}\right), 131.42$ (s), 130.54 (d, $\left.J=90.0 \mathrm{~Hz}\right)$, 128.22 (d, $J=10.8 \mathrm{~Hz}$ ), 36.99 (d, $J=72.8 \mathrm{~Hz}$ ), 36.42 (s), 35.34 (s), 27.50 (d, $J=10.2 \mathrm{~Hz}$ ). This compound is known. ${ }^{13}$<smiles>CP[PH3](C)c1ccccc1</smiles>

Methyldiphenylphosphine (2ab). ${ }^{31}$ P NMR (162 MHz, $\left.\mathbf{C D C l}_{3}\right) \delta=-26.75$ (s, 98\%).

Methyldiphenylphosphine oxide (4ab). White solid: 42.0 mg, 88\% yield. ${ }^{31} \mathrm{P}$ NMR (162 MHz, $\left.\mathrm{CDCl}_{3}\right) \delta=30.46(\mathrm{~s}) ;{ }^{1} \mathrm{H}$ NMR $\left(400 \mathrm{MHz}, \mathrm{CDCl}_{3}\right) \delta=7.76-7.64$ (m, 4H), $7.54-7.37$ (m, 6H), $2.00(\mathrm{dt}, J=13.2,1.5 \mathrm{~Hz}, 3 \mathrm{H}) ;{ }^{13} \mathrm{C}$ NMR $\left(101 \mathrm{MHz}, \mathrm{CDCl}_{3}\right) \delta=134.15$ (d, $\left.J=101.1 \mathrm{~Hz}\right), 131.81$ (d, $J=2.4 \mathrm{~Hz}), 130.59$ (d, $J=9.7 \mathrm{~Hz}), 128.72$ (d, $J=11.7 \mathrm{~Hz}), 16.65$ (d, $J=73.6 \mathrm{~Hz}$ ). This compound is known. ${ }^{14}$

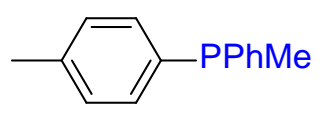

p-Tolylmethylphenylphosphine (2ac). Colorless oil: 34.3 mg, 80\% yield. ${ }^{31} \mathrm{P}$ NMR (162 MHz, 
$\left.\mathrm{CDCl}_{3}\right) \delta=-27.24(\mathrm{~s}) ;{ }^{1} \mathrm{H}$ NMR $\left(400 \mathrm{MHz}, \mathrm{CDCl}_{3}\right) \delta=7.39(\mathrm{td}, J=7.6,1.6 \mathrm{~Hz}, 2 \mathrm{H}), 7.36-7.27$ (m, 5H), 7.16 (d, $J=7.7 \mathrm{~Hz}, 2 \mathrm{H}), 2.35$ (s, 3H), 1.61 (d, $J=3.5 \mathrm{~Hz}, 3 \mathrm{H}) ;{ }^{13} \mathrm{C}$ NMR (101 MHz, $\left.\mathrm{CDCl}_{3}\right) \delta=140.73$ (s), 138.57 (s), 136.56 (s), 132.41 (d, $\left.J=18.9 \mathrm{~Hz}\right), 131.97$ (d, $J=18.2 \mathrm{~Hz}$ ), 129.33 (d, $J=6.9 \mathrm{~Hz}), 128.42$ (d, $J=6.1 \mathrm{~Hz}), 128.26$ (s), 21.37 (s), 12.77 (d, $J=13.4 \mathrm{~Hz}$ ). This compound is known. ${ }^{15}$<smiles>C[PH3+][PH](=O)c1ccc(C(C)(C)C)cc1</smiles>

4-tert-Butylphenylmethylphenylphosphine (4ad). ${ }^{31} \mathrm{P} \mathrm{NMR}\left(162 \mathrm{MHz}, \mathrm{CDCl}_{3}\right) \delta=-28.19$ (s).

4-tert-Butylphenylmethylphenylphosphine oxide (4ad). White solid: $43.6 \mathrm{mg}, 80 \%$ yield; m.p. $129.1-131.4{ }^{\circ} \mathrm{C} .{ }^{31} \mathrm{P}$ NMR $\left(162 \mathrm{MHz}, \mathrm{CDCl}_{3}\right) \delta=30.66(\mathrm{~s}) ;{ }^{1} \mathrm{H}$ NMR $\left(400 \mathrm{MHz}, \mathrm{CDCl}_{3}\right) \delta=$ 7.69 (d, $J=8.4 \mathrm{~Hz}, 2 \mathrm{H}), 7.65-7.55(\mathrm{~m}, 2 \mathrm{H}), 7.44(\mathrm{~d}, J=6.1 \mathrm{~Hz}, 5 \mathrm{H}), 1.97$ (d, $J=12.4 \mathrm{~Hz}, 3 \mathrm{H})$, 1.27 (t, $J=6.7 \mathrm{~Hz}, 9 \mathrm{H}) ;{ }^{13} \mathrm{C}$ NMR (101 MHz, $\left.\mathrm{CDCl}_{3}\right) \delta=155.29$ (s), 131.73 (s), 130.71 (s), 130.60 (s), 130.50 (s), 128.70 (d, $J=11.2 \mathrm{~Hz}), 125.75$ (d, $J=11.5 \mathrm{~Hz}$ ), 35.03 (s), 31.18 (s). HRMS (ESI ${ }^{+}$) Calcd. for $\mathrm{C}_{17} \mathrm{H}_{21} \mathrm{OPNa}\left[\mathrm{M}+\mathrm{Na}^{+}\right]$: 295.1228, Found: 295.1247.

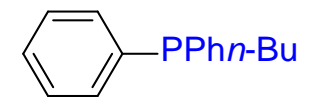

n-Butyldiphenylphosphine (2ae). Pale yellow oil: $47.7 \mathrm{mg}$, 88\% yield. ${ }^{31} \mathrm{P}$ NMR (162 MHz, $\left.\mathrm{CDCl}_{3}\right) \delta=-15.41(\mathrm{~s}) ;{ }^{1} \mathrm{H}$ NMR $\left(400 \mathrm{MHz}, \mathrm{CDCl}_{3}\right) \delta=7.41(\mathrm{td}, J=7.4,1.8 \mathrm{~Hz}, 2 \mathrm{H}), 7.32(\mathrm{~d}, J=$ $5.7 \mathrm{~Hz}, 3 \mathrm{H}), 2.03$ (d, $J=7.1 \mathrm{~Hz}, 1 \mathrm{H}), 1.44$ (d, $J=7.4 \mathrm{~Hz}, 3 \mathrm{H}), 0.89$ (t, $J=6.4 \mathrm{~Hz}, 2 \mathrm{H}) ;{ }^{13} \mathrm{C}$ NMR $\left(101 \mathrm{MHz}, \mathrm{CDCl}_{3}\right) \delta=139.19$ (s), 132.79 (d, $\left.J=18.3 \mathrm{~Hz}\right), 128.50$ (s), 128.44 (d, $\left.J=6.6 \mathrm{~Hz}\right)$, 28.23 (d, $J=15.9 \mathrm{~Hz}), 27.85$ (d, $J=10.8 \mathrm{~Hz}), 24.41$ (d, $J=13.1 \mathrm{~Hz}), 13.88$ (s). This compound is known. ${ }^{16}$<smiles>CCCCCCCCCCCCCCCCCC</smiles>

2-Naphthyln-butylphenylphosphane (2af). Colorless solid : $47.7 \mathrm{mg}, 82 \%$ yield. ${ }^{31} \mathrm{P}$ NMR (162 $\left.\mathrm{MHz}, \mathrm{CDCl}_{3}\right) \delta=-14.82(\mathrm{~s}) ;{ }^{1} \mathrm{H} \mathrm{NMR}\left(400 \mathrm{MHz}, \mathrm{CDCl}_{3}\right) \delta=7.99(\mathrm{~d}, J=8.6 \mathrm{~Hz}, 1 \mathrm{H}), 7.84-$ 7.79 (m, 2H), 7.78 (d, $J=8.5$ Hz, 1H), 7.52 - 7.47 (m, 2H), 7.47 - 7.41 (m, 3H), 7.35 - 7.30 (m, 
3H), 2.15 (dd, $J=16.5,7.6 \mathrm{~Hz}, 2 \mathrm{H}), 1.46$ (dd, $J=7.9,3.9 \mathrm{~Hz}, 4 \mathrm{H}), 0.91$ (t, $J=6.9 \mathrm{~Hz}, 3 \mathrm{H}$ ); ${ }^{13} \mathrm{C}$ $\operatorname{NMR}\left(101 \mathrm{MHz}, \mathrm{CDCl}_{3}\right) \delta=139.25(\mathrm{~d}, J=13.2 \mathrm{~Hz}), 136.43(\mathrm{~d}, J=13.1 \mathrm{~Hz}), 133.43$ (d, $J=4.4$ Hz), 133.22 (s), 132.85 (s), 132.67 (s), 129.19 (d, $J=14.0 \mathrm{~Hz}), 128.51$ (s), 128.45 (s), 128.08 (s), 127.99 (d, $J=5.8 \mathrm{~Hz}), 127.79$ (s), 126.59 (s), 126.33 (s), 28.25 (d, $J=15.7 \mathrm{~Hz}), 27.76$ (d, $J=$ $11.3 \mathrm{~Hz}$ ), 24.45 (d, $J=13.1 \mathrm{~Hz}), 13.92$ (s). HRMS (ESI ${ }^{+}$) Calcd. for $\mathrm{C}_{20} \mathrm{H}_{22} \mathrm{P}\left[\mathrm{M}+\mathrm{H}^{+}\right]$: 293.1459, Found: 293.1431. This compound is known. ${ }^{17}$<smiles>CCCC[Pb](O)c1ccccc1</smiles>

Di-n-Butylphenylphosphine (2ag). ${ }^{31}$ P NMR (162 MHz, $\left.\mathrm{CDCl}_{3}\right) \delta=-24.82$ (s).

Di-n-Butylphenylphosphine oxide (4ag). White solid: 42.0 mg, 88\% yield. ${ }^{31} \mathrm{P}$ NMR (162 MHz, $\left.\mathrm{CDCl}_{3}\right) \delta=41.71(\mathrm{~s}) ;{ }^{1} \mathrm{H}$ NMR $\left(400 \mathrm{MHz}, \mathrm{CDCl}_{3}\right) \delta=7.70-7.60(\mathrm{~m}, 2 \mathrm{H}), 7.46$ (dddd, $J=8.0$, 6.4, 5.1, $1.5 \mathrm{~Hz}, 3 \mathrm{H}), 1.99-1.88$ (m, 2H), $1.86-1.76$ (m, 2H), 1.60 - 1.51 (m, 2H), $1.42-1.29$ (m, 6H), 0.83 (t, $J=7.1 \mathrm{~Hz}, 6 \mathrm{H}) ;{ }^{13} \mathrm{C}$ NMR $\left(101 \mathrm{MHz}, \mathrm{CDCl}_{3}\right) \delta=132.58$ (d, $\left.J=92.0 \mathrm{~Hz}\right)$, 131.51 (s), 130.45 (d, $J=8.8 \mathrm{~Hz}), 128.67$ (d, $J=11.1 \mathrm{~Hz}$ ), $30.13-29.18$ (m), 24.16 (d, $J=14.5$ $\mathrm{Hz}$ ), 23.55 (d, $J=4.0 \mathrm{~Hz}), 13.63$ (s). This compound is known. ${ }^{18}$<smiles>CCOPc1cc(OC)cc(Pc2ccccc2)c1</smiles>

1,3,5-Tris(methylphenylphosphaneyl)benzene (2ah). ${ }^{31} \mathrm{P}$ NMR (162 MHz, $\left.\mathrm{CDCl}_{3}\right) \delta=-25.43$ (s).

1,3,5-Tris(methylphenylphosphoryl)benzene (4ah). White solid: 91.2 mg, 88\% yield; m.p. 218.2 $-221.5{ }^{\circ} \mathrm{C} .{ }^{31} \mathrm{P}$ NMR $\left(162 \mathrm{MHz}, \mathrm{CDCl}_{3}\right) \delta=29.62(\mathrm{~s}) ;{ }^{1} \mathrm{H}$ NMR $\left(400 \mathrm{MHz}, \mathrm{CDCl}_{3}\right) \delta=8.27-$ 8.11 (m, 3H), 7.69 - 7.57 (m, 6H), 7.48 (ddd, $J=15.0,7.2,5.2 \mathrm{~Hz}, 5 \mathrm{H}), 7.43-7.38$ (m, 4H), 1.99 (d, $J=13.2 \mathrm{~Hz}, 9 \mathrm{H}) ;{ }^{13} \mathrm{C}$ NMR $\left(101 \mathrm{MHz}, \mathrm{CDCl}_{3}\right) \delta=136.34$ (d, $\left.J=95.9 \mathrm{~Hz}\right), 135.26$ (s), 133.27 (s), 132.34 (s), 130.40 (d, $J=10.2 \mathrm{~Hz}$ ), 128.99 (d, $J=12.3 \mathrm{~Hz}$ ), 16.51 (d, $J=74.2 \mathrm{~Hz}$ ). Elemental Analysis: Calcd. for $\mathrm{C}_{27} \mathrm{H}_{27} \mathrm{O}_{3} \mathrm{P}_{3}$; C, 65.86; H, 5.53; Found: C, 66.01; H, 5.36. HRMS (ESI ${ }^{+}$) Calcd. for $\mathrm{C}_{27} \mathrm{H}_{27} \mathrm{O}_{3} \mathrm{P}_{3} \mathrm{Na}\left[\mathrm{M}+\mathrm{Na}^{+}\right]$: 515.1071, Found: 515.1048. 
$\mathrm{MePh}(\mathrm{O}) \mathrm{P}$

(3-Diphenylphosphino)phenylmethylphenylphosphine (2ai). ${ }^{31} \mathrm{P}$ NMR (162 MHz, $\left.\mathrm{CDCl}_{3}\right) \delta=$ $-4.69(\mathrm{~s}),-26.35$ (s).

(3-Diphenylphosphino)phenylmethylphenylphosphine oxide (4ai). White solid: $60.4 \mathrm{mg}$, 8\% yield; m.p. $179.1-181.4{ }^{\circ} \mathrm{C} .{ }^{31} \mathrm{P}$ NMR (162 MHz, $\left.\mathrm{CDCl}_{3}\right) \delta=33.20$ (s), 31.67 (s); ${ }^{1} \mathrm{H}$ NMR (400 $\left.\mathrm{MHz}, \mathrm{CDCl}_{3}\right) \delta=8.05-7.93(\mathrm{~m}, 2 \mathrm{H}), 7.79-7.71(\mathrm{~m}, 1 \mathrm{H}), 7.70-7.63(\mathrm{~m}, 2 \mathrm{H}), 7.62-7.53(\mathrm{~m}$, 7H), $7.53-7.38$ (m, 7H), 2.05 (d, $J=13.3 \mathrm{~Hz}, 3 \mathrm{H}) ;{ }^{13} \mathrm{C}$ NMR $\left(101 \mathrm{MHz}, \mathrm{CDCl}_{3}\right) \delta=135.37(\mathrm{~s})$, 134.46 (s), 134.34 - 134.15 (m), 133.62 (s), 132.74 (s), 132.38 (s), 132.13 (s), 132.04 (s), 131.80 131.62 (m), 131.33 (s), 130.54 (d, $J=10.0 \mathrm{~Hz}), 130.28$ (s), 129.27 (s), 129.04 (d, $J=5.0 \mathrm{~Hz}$ ), 128.95 (s), 128.86 (d, $J=5.5 \mathrm{~Hz}), 16.22$ (d, $J=74.2 \mathrm{~Hz}$ ). HRMS (ESI ${ }^{+}$) Calcd. for $\mathrm{C}_{25} \mathrm{H}_{22} \mathrm{O}_{2} \mathrm{P}_{2} \mathrm{Na}\left[\mathrm{M}+\mathrm{Na}^{+}\right]$: 439.0993, Found: 439.0989.<smiles>c1ccc(P(CCCCP(c2ccccc2)c2cccc3ccccc23)c2cccc3ccccc23)cc1</smiles>

1,4-Bis(1-naphthalenylphenylphosphino)butane (2aj). White solid: 194.6 mg, 74\% yield; m.p. $144.6-147.1{ }^{\circ} \mathrm{C} .{ }^{31} \mathrm{P}$ NMR $\left(162 \mathrm{MHz}, \mathrm{CDCl}_{3}\right) \delta=-24.77$ (s); ${ }^{1} \mathrm{H}$ NMR $\left(400 \mathrm{MHz}, \mathrm{CDCl}_{3}\right) \delta=$ $8.53-8.46$ (m, 2H), 7.84 (d, $J=7.9 \mathrm{~Hz}, 4 \mathrm{H}), 7.51-7.42$ (m, 8H), $7.41-7.35$ (m, 5H), 7.31 (d, $J$ $=3.4 \mathrm{~Hz}, 1 \mathrm{H}), 7.27(\mathrm{~d}, J=2.8 \mathrm{~Hz}, 4 \mathrm{H}), 2.12(\mathrm{dd}, J=14.0,9.0 \mathrm{~Hz}, 4 \mathrm{H}), 1.63(\mathrm{~d}, J=17.6 \mathrm{~Hz}, 4 \mathrm{H})$; ${ }^{13} \mathrm{C}$ NMR $\left(101 \mathrm{MHz}, \mathrm{CDCl}_{3}\right) \delta=138.69(\mathrm{~d}, J=13.0 \mathrm{~Hz}), 135.72(\mathrm{~d}, J=36.0 \mathrm{~Hz}), 135.70(\mathrm{~s})$, 133.64 (s), 132.90 (s), 132.71 (s), 129.91 (s), 129.40 (s), 128.76 (s), 128.55 (s), 128.50 (s), 126.25 (s), 125.98 (s), 125.87 (d, $J=60.0 \mathrm{~Hz}$ ), 28.09 - 27.66 (m), 27.48 (d, $J=11.8 \mathrm{~Hz}$ ). Elemental Analysis: Calcd. for $\mathrm{C}_{36} \mathrm{H}_{32} \mathrm{P}_{2}$; C, 82.11; H, 6.13; Found: C, 81.84; H, 6.35. HRMS (ESI ${ }^{+}$) Calcd. for $\mathrm{C}_{36} \mathrm{H}_{33} \mathrm{P}_{2}\left[\mathrm{M}+\mathrm{H}^{+}\right]$: 527.2057, Found: 527.2034. 
<smiles>CCCOP(c1ccccc1)c1cccc2ccccc12</smiles>

1-Naphthyln-butylphenylphosphane (2al). Colorless oil: 194.6 mg, 74\% yield. ${ }^{31} \mathrm{P}$ NMR (162 $\left.\mathrm{MHz}, \mathrm{CDCl}_{3}\right) \delta=-27.73(\mathrm{~s}) ;{ }^{1} \mathrm{H}$ NMR $\left(400 \mathrm{MHz}, \mathrm{CDCl}_{3}\right) \delta=8.65$ (dd, $\left.J=9.7,4.3 \mathrm{~Hz}, 1 \mathrm{H}\right), 7.92$ - 7.87 (m, 2H), $7.64-7.59$ (m, 1H), 7.52 (dd, $J=6.3,3.3 \mathrm{~Hz}, 5 \mathrm{H}), 7.40$ (dd, $J=10.7,4.8 \mathrm{~Hz}$, 1H), 7.33 (s, 2H), $2.30-2.16$ (m, 2H), $1.65-1.49$ (m, 4H), 0.98 (t, $J=6.9 \mathrm{~Hz}, 3 \mathrm{H}) ;{ }^{13} \mathrm{C}$ NMR $\left(101 \mathrm{MHz}, \mathrm{CDCl}_{3}\right) \delta=139.01(\mathrm{~d}, J=12.8 \mathrm{~Hz}), 136.04(\mathrm{~d}, J=2.2 \mathrm{~Hz}), 135.85(\mathrm{~d}, J=7.0 \mathrm{~Hz})$, 133.75 (d, $J$ = $4.1 \mathrm{~Hz}$ ), 132.99 (s), 132.80 (s), 129.91 (s), 129.41 (s), 128.83 (s), 128.61 (s), 128.55 (s), 126.24 (d, $J=27.0 \mathrm{~Hz}$ ), 126.03 (s), 125.92 (d, $J=56.0 \mathrm{~Hz}$ ), 28.52 (d, $J=16.5 \mathrm{~Hz}$ ), 27.62 (d, $J=11.4 \mathrm{~Hz}$ ), $24.56(\mathrm{~d}, J=13.5 \mathrm{~Hz}), 14.01$ (s). HRMS (ESI ${ }^{+}$) Calcd. for $\mathrm{C}_{20} \mathrm{H}_{22} \mathrm{P}\left[\mathrm{M}+\mathrm{H}^{+}\right]$: 293.1459, Found: 293.1431.

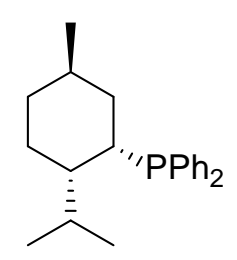

(+)-Neomenthyldiphenylphosphine (NMDPP). White solid: $37.1 \mathrm{mg}, 52 \%$ yield. ${ }^{31} \mathrm{P}$ NMR (162 $\left.\mathrm{MHz}, \mathrm{CDCl}_{3}\right) \delta=-14.41(\mathrm{~s}) ;{ }^{1} \mathrm{H}$ NMR $\left(400 \mathrm{MHz}, \mathrm{CDCl}_{3}\right) \delta=7.68(\mathrm{dd}, J=11.3,3.7 \mathrm{~Hz}, 2 \mathrm{H})$, $7.60-7.52$ (m, 2H), 7.28 (ddd, $J=7.4,5.1,3.4 \mathrm{~Hz}, 6 \mathrm{H}), 1.74$ (d, $J=6.6 \mathrm{~Hz}, 4 \mathrm{H}), 1.48$ (dt, $J=$ 12.9, $6.5 \mathrm{~Hz}, 1 \mathrm{H}), 1.41-1.26$ (m, 2H), $1.22-1.14$ (m, 1H), 0.86 (dd, $J=11.8,6.2 \mathrm{~Hz}, 1 \mathrm{H}), 0.78$ (d, $J=6.5 \mathrm{~Hz}, 3 \mathrm{H}), 0.64$ (d, $J=6.4 \mathrm{~Hz}, 3 \mathrm{H}), 0.53$ (d, $J=6.4 \mathrm{~Hz}, 3 \mathrm{H}) ;{ }^{13} \mathrm{C}$ NMR $(101 \mathrm{MHz}$, $\left.\mathrm{CDCl}_{3}\right) \delta=135.17(\mathrm{~d}, J=22.2 \mathrm{~Hz}), 133.91(\mathrm{~d}, J=21.1 \mathrm{~Hz}), 128.62(\mathrm{~d}, J=17.6 \mathrm{~Hz}), 128.15$ (t, $J$ = $7.2 \mathrm{~Hz}$ ), 49.85 (d, $J$ = $15.3 \mathrm{~Hz}$ ), 39.19 (s), 35.97 (s), 35.53 (d, $J=18.2 \mathrm{~Hz}$ ), 29.95 (s), 27.48 (s), 26.06 (s), 22.35 (d, $J=33.4 \mathrm{~Hz}$ ), 21.06 (s). This compound is known. ${ }^{19}$

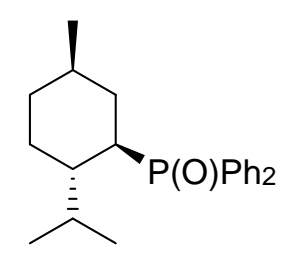

(-)-Menthyl diphenylphosphine (MDPP). ${ }^{31}$ P NMR (162 MHz, $\left.\mathbf{C D C l}_{3}\right) \delta=-4.96$ (s, 54\%). 
(-)-Menthyldiphenylphosphine oxide. White solid: $31.3 \mathrm{mg}, 45 \%$ yield. ${ }^{31} \mathrm{P}$ NMR (162 MHz, $\left.\mathrm{CDCl}_{3}\right) \delta=34.40(\mathrm{~s}) ;{ }^{1} \mathrm{H}$ NMR $\left(400 \mathrm{MHz}, \mathrm{CDCl}_{3}\right) \delta=7.88-7.80(\mathrm{~m}, 2 \mathrm{H}), 7.79-7.72(\mathrm{~m}, 2 \mathrm{H})$, $7.46-7.40$ (m, 6H), 2.33 (s, 1H), $2.02-1.95$ (m, 1H), 1.72 (dd, $J=21.0,9.1 \mathrm{~Hz}, 4 \mathrm{H}), 1.49$ (s, 1H), $1.15-1.04$ (m, 2H), 0.92 (dd, $J=10.1,6.7 \mathrm{~Hz}, 1 \mathrm{H}), 0.76$ (d, $J=6.3 \mathrm{~Hz}, 6 \mathrm{H}), 0.47$ (d, $J=$ 6.7 Hz, 3H). This compound is known. ${ }^{19}$

\section{References:}

(1) Yu, R.; Chen, X.; Wang, Z. Tetrahedron Lette. 2016, 57, 3404-3406.

(2) Allen, D.V.; Venkataraman, D. J. Orgnomet. Chem. 2003, 68, 4590-4593.

(3) Brune, H. A.; Falck, M.; Hemmer, R.; Schmidtberg, G.; Alt, H. G. Chem. Ber. 1984, 117, 2791-2802.

(4) PubChem ID: 11186665.

(5) PubChem ID: 88026852.

(6) Xu, Z; Wang. P; Chen, Q; Cai, M. J. Org. Chem. 2018, 866, 50-58.

(7) Kuang, S. M.; Zhang, Z. Z.; Wang, Q. G.; Mak, T. C. J. Chem. Soc., Dalton Trans. 1998, 17, 2927-2930.

(8) Stott, T. L.; Wolf, M. O. J. Phys. Chem. B 2004, 108, 18815-18819.

(9) PubChem ID: 19987685.

(10) Yuan, J.; Zhu, L.; Zhang, J.; Li, J.; Cui, C. Organometallics 2017, 36, 455-459.

(11) Cain, M. F.; Hughes, R. P.; Glueck, D. S.; Golen, J. A.; Moore, C. E.; Rheingold, A. L. Inorg. Chem. 2010, 49, 7650-7662.

(12) Zhang, P. Z.; Zhang, L.; Li, J. A.; Shoberu, A; Zou, J. P.; Zhang, W. Org. lett. 2017, 19, 5537-5540.

(13) Moncea, O.; Gunawan, M. A.; Poinsot, D.; Cattey, H.; Becker, J.; Yurchenko, R. I.; Butova, E. D.; Hausmann, H.; Šekutor, M; Fokin, A. A; Hierso, J. C. J. Org. Chem. 2016, 81, 8759-8769.

(14) Denton, R. M.; An, J.; Adeniran, B.; Blake, A. J.; Lewis, W.; Poulton, A. M. J. Org. Chem. 2011, 76, 6749-6767.

(15) Reaxys ID: 2937979.

(16) Stankevič, M.; Pisklak, J.; Włodarczyk, K. Tetrahedron 2016, 72, 810-824.

(17) Holz, J.; Jiao, H.; Gandelman, M.; Börner, A. Eur. J. Org. Chem. 2018, 2018, 2984-2994.

(18) Chen, Q.; Yan, X.; Du, Z.; Zhang, K.; Wen, C. J. Org. Chem. 2016, 81, 276-281.

(19) Koller, S.; Gatzka, J.; Wong, K. M.; Altmann, P. J.; Pöthig, A.; Hintermann, L. J. Org. Chem. 2018, 83, 15009-15028. 


\section{Part 11. Copies of ${ }^{1} \mathrm{H},{ }^{31} \mathrm{P}$ and ${ }^{13} \mathrm{C}$ NMR spectra.}

Figure S66: ${ }^{31} \mathrm{P}$ NMR (162 MHz, Chloroform- $d$ ) for triphenylphosphine (2a).
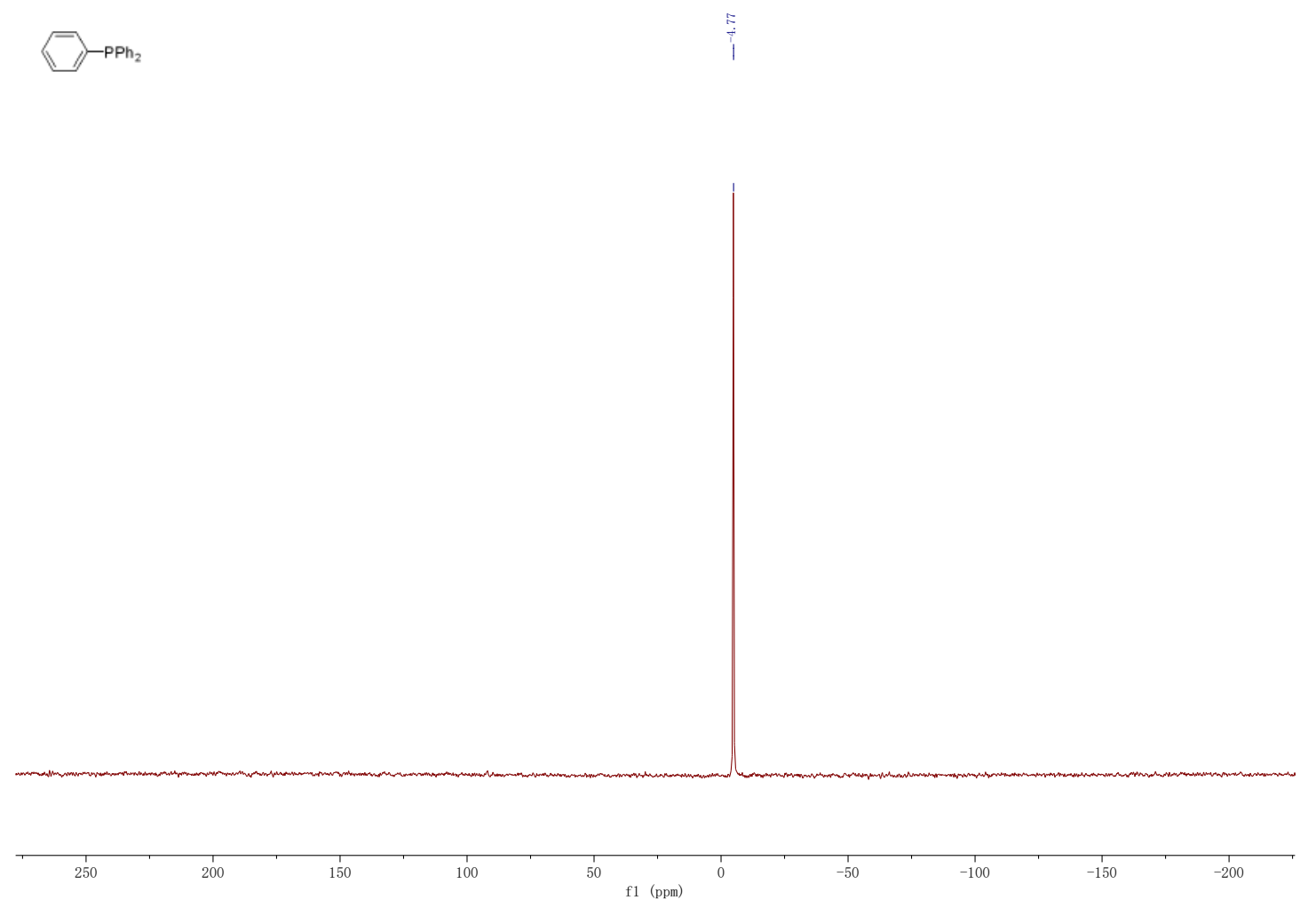

Figure S67: ${ }^{1} \mathrm{H}$ NMR (400 MHz, Chloroform-d) for triphenylphosphine (2a).
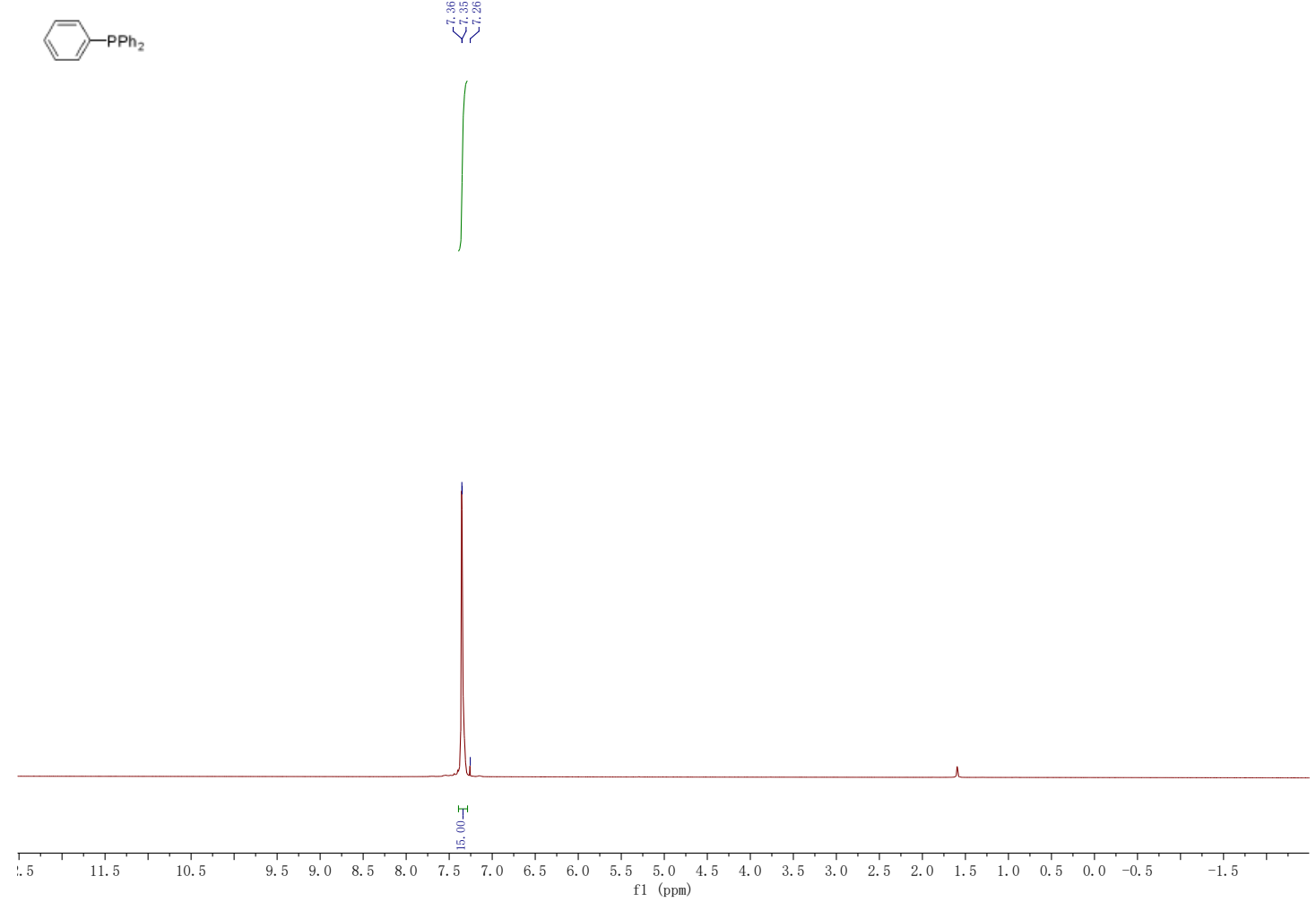
Figure S68: ${ }^{31} \mathrm{P}$ NMR (162 MHz, Chloroform-d) for diphenyl(4-tolyl)phosphine (2b).
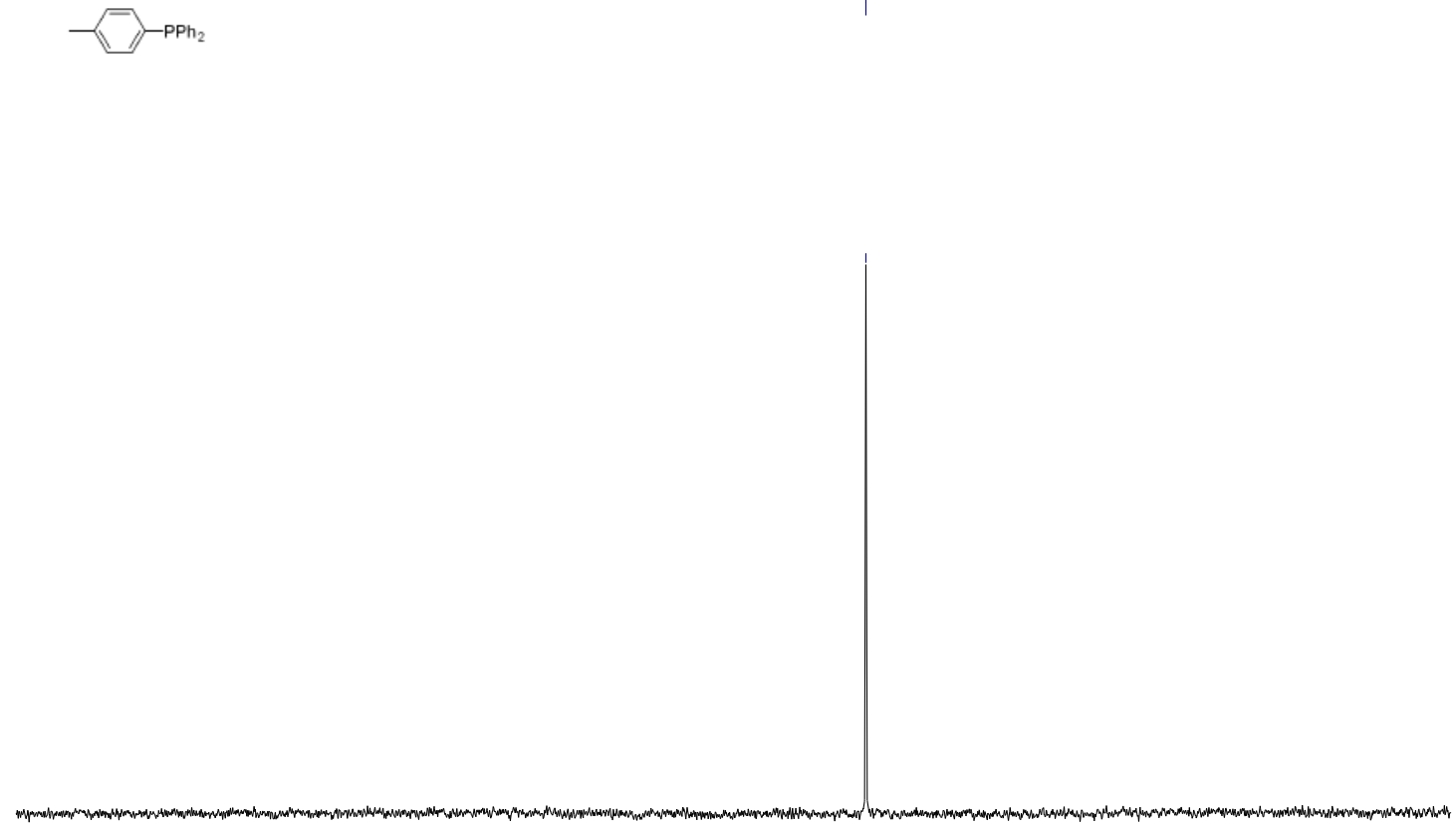

Figure S69: ${ }^{1} \mathrm{H}$ NMR (400 MHz, Chloroform-d) for diphenyl(4-tolyl)phosphine (2b).

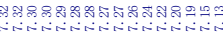

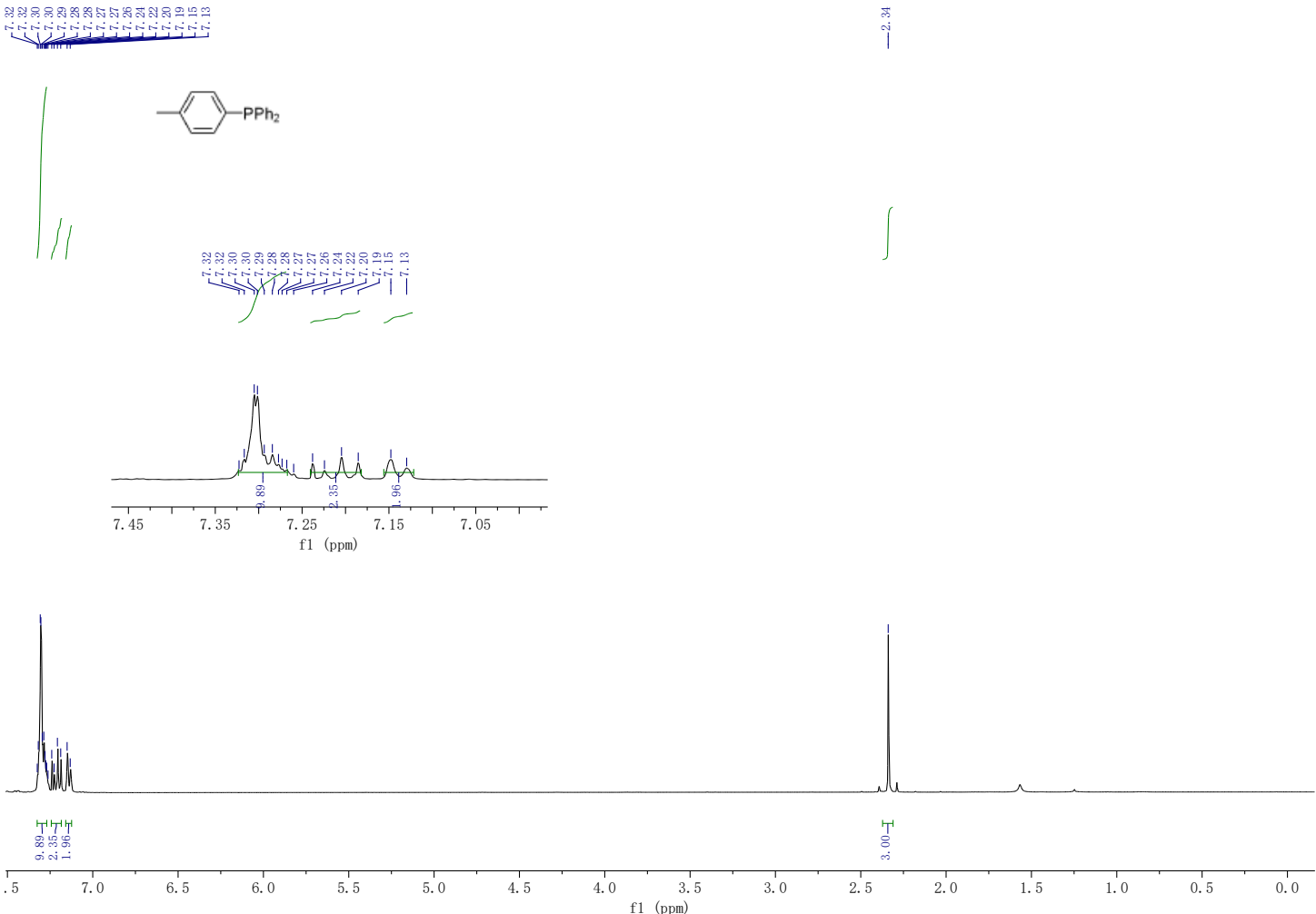


Figure S70: ${ }^{13} \mathrm{C}$ NMR (101 MHz, Chloroform-d) for diphenyl(4-tolyl)phosphine (2b).

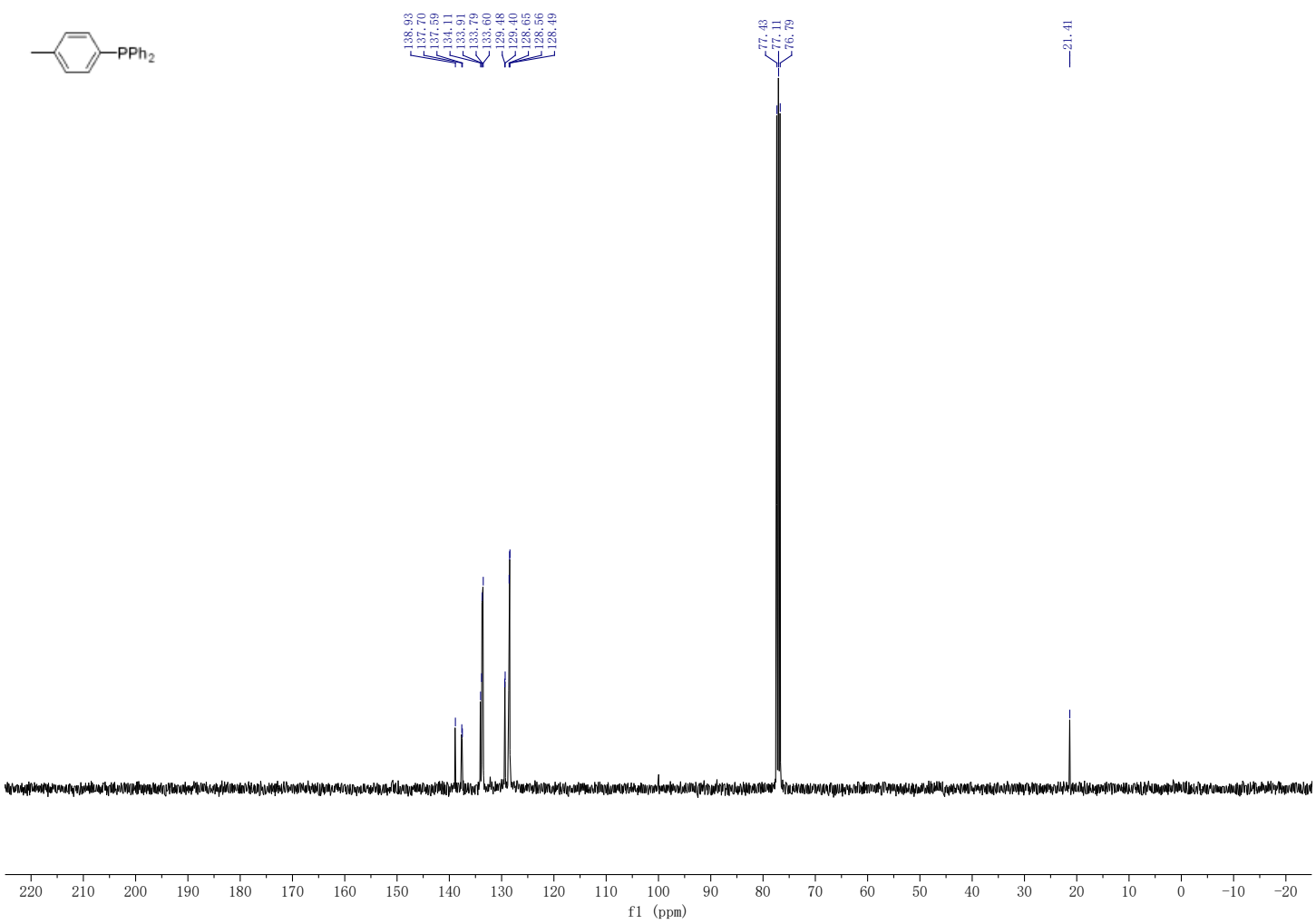

Figure S71: ${ }^{31} \mathrm{P}$ NMR analysis (162 MHz, Chloroform- $d$ ) for (4-n-butylphenyl)diphenylphosphine (2c).
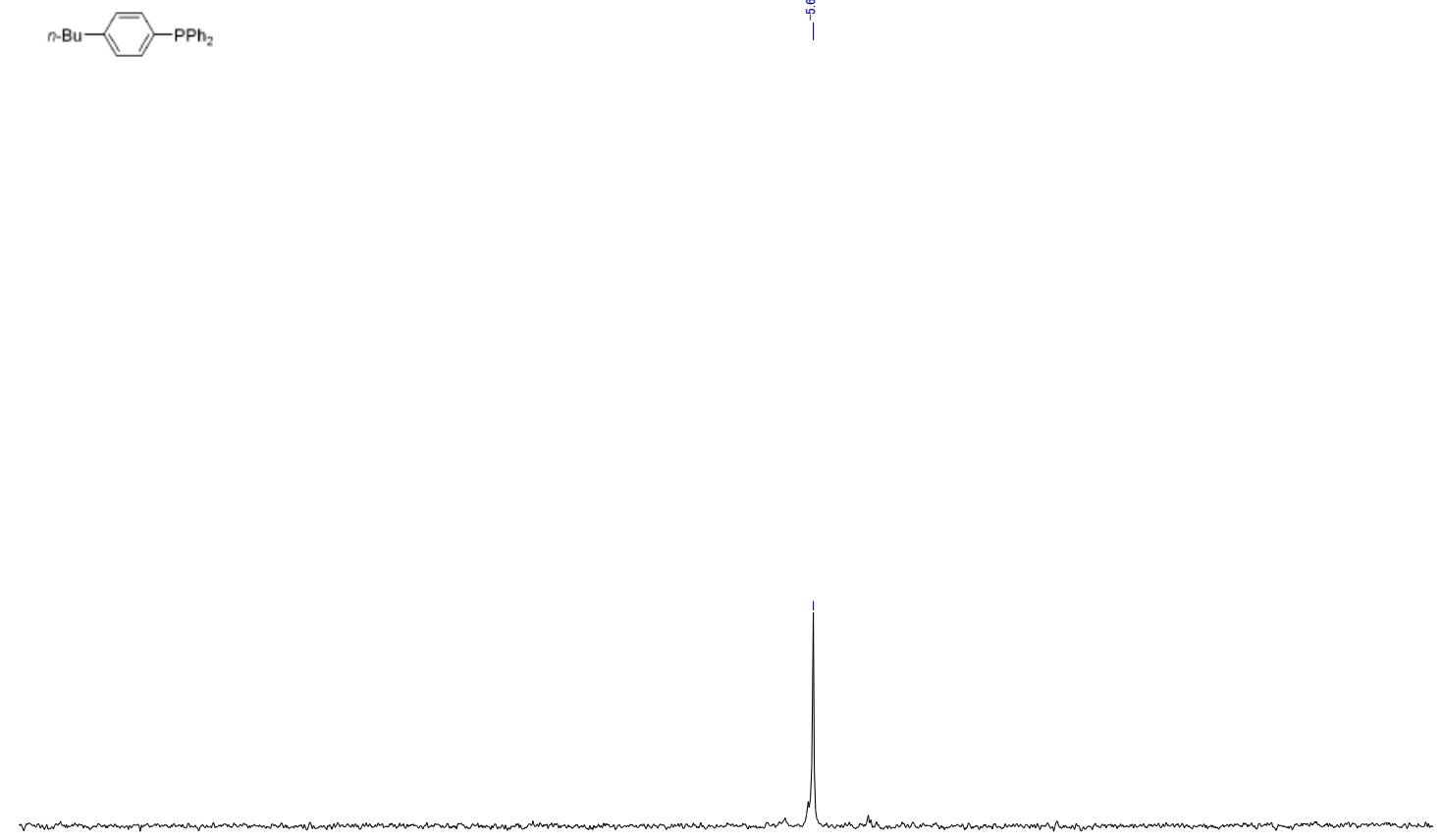

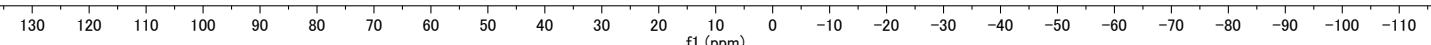


Figure S72: ${ }^{1} \mathrm{H}$ NMR (400 MHz, Chloroform- $d$ ) for (4-n-butylphenyl)diphenylphosphine (2c).

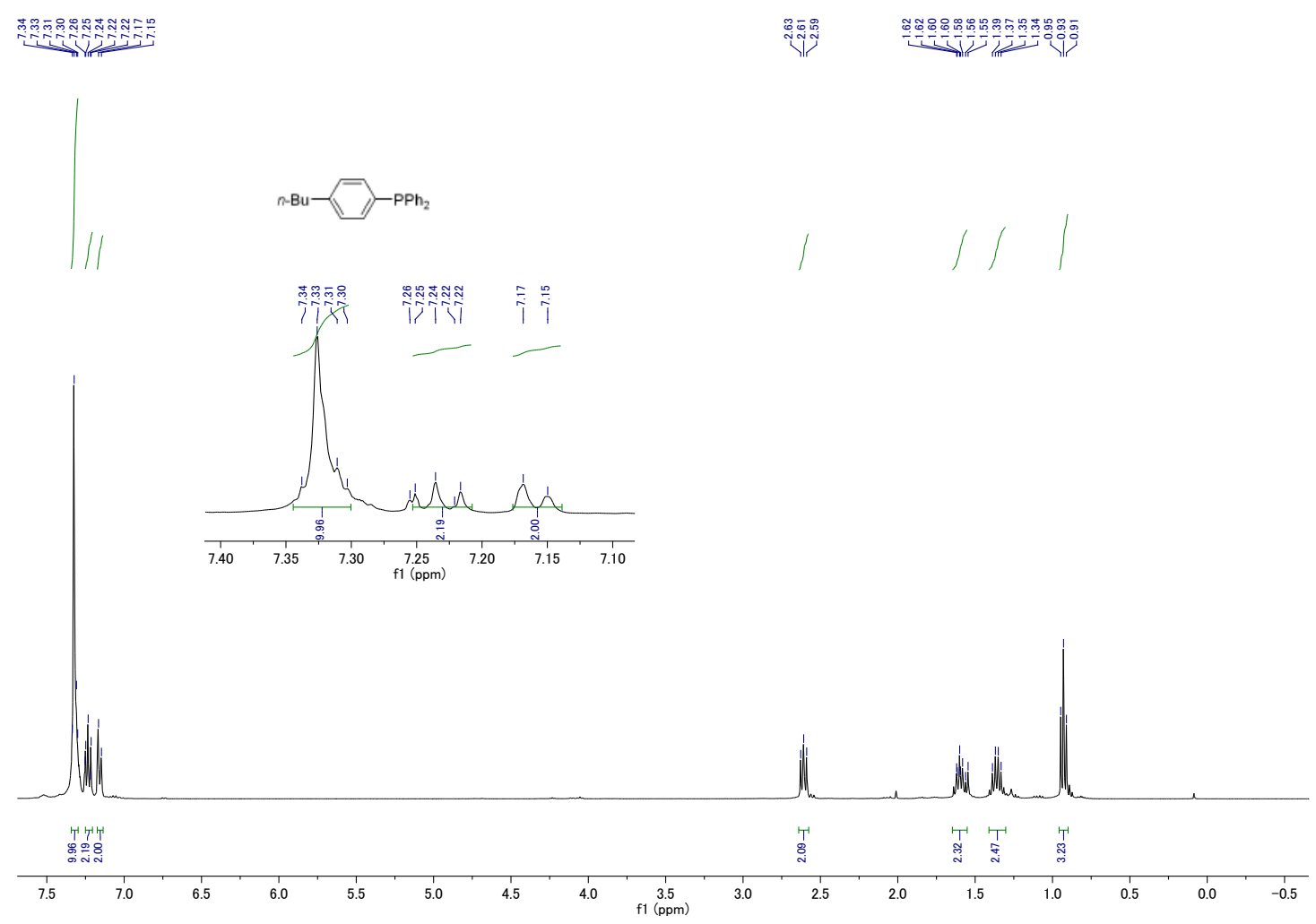

Figure S73: ${ }^{13} \mathrm{C}$ NMR (101 MHz, Chloroform- $d$ ) for (4-n-butylphenyl)diphenylphosphine (2c).
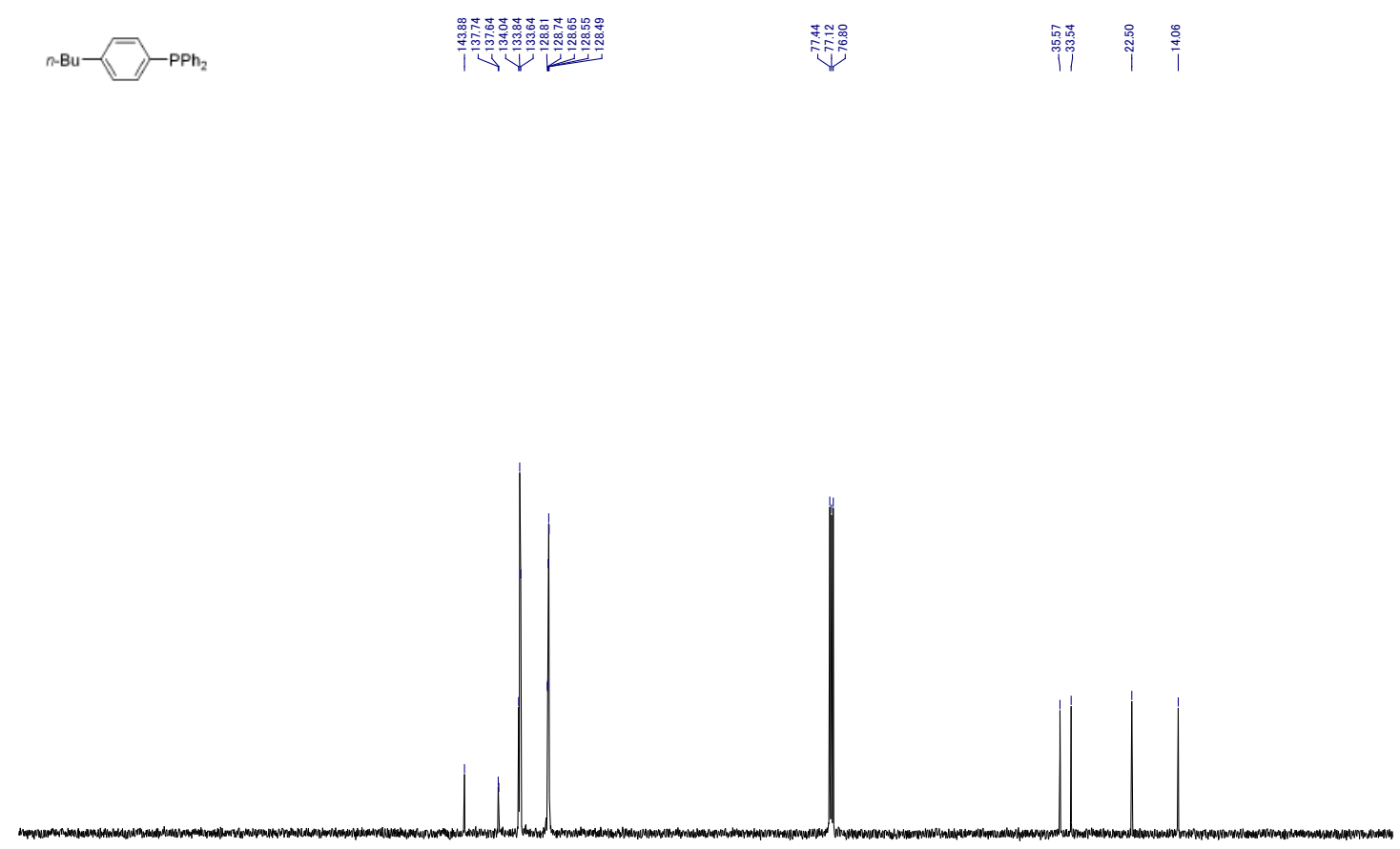

\begin{tabular}{llllllllllllllllllllllllllll}
1 & 1 \\
\hline 220 & 210 & 200 & 190 & 180 & 170 & 160 & 150 & 140 & 130 & 120 & 110 & $\underset{f 1}{100}$ & 90 & 80 & 70 & 60 & 50 & 40 & 30 & 20 & 10 & 0 & -10 & -20
\end{tabular} 
Figure S74: ${ }^{31} \mathrm{P}$ NMR (162 MHz, Chloroform-d) for (4-tert-butylphenyl)diphenylphosphine (2d). $t-\mathrm{Bu} \longrightarrow \mathrm{PPh}_{2}$

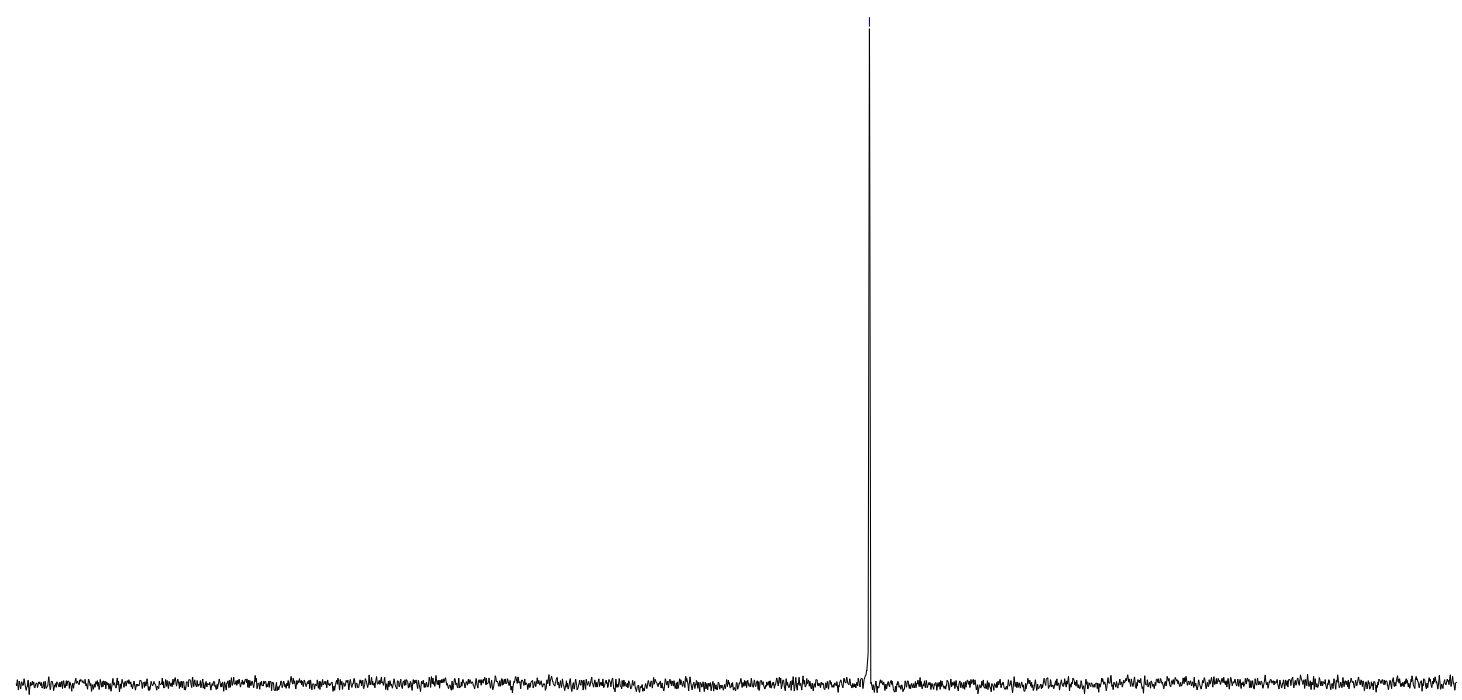

$\begin{array}{lllllllllllllllllllllllllllllllll}340 & 320 & 300 & 280 & 260 & 240 & 220 & 200 & 180 & 160 & 140 & 120 & 100 & 80 & 60 & 40 & 20 & 0 & -20 & -40 & -60 & -80 & -100 & -140 & -180 & -220 & 1 & 1 & 1 & 1 & 1 & 1 & 1\end{array}$

Figure S75: ${ }^{1} \mathrm{H}$ NMR (400 MHz, Chloroform-d) for (4-tert-butylphenyl)diphenylphosphine (2d).

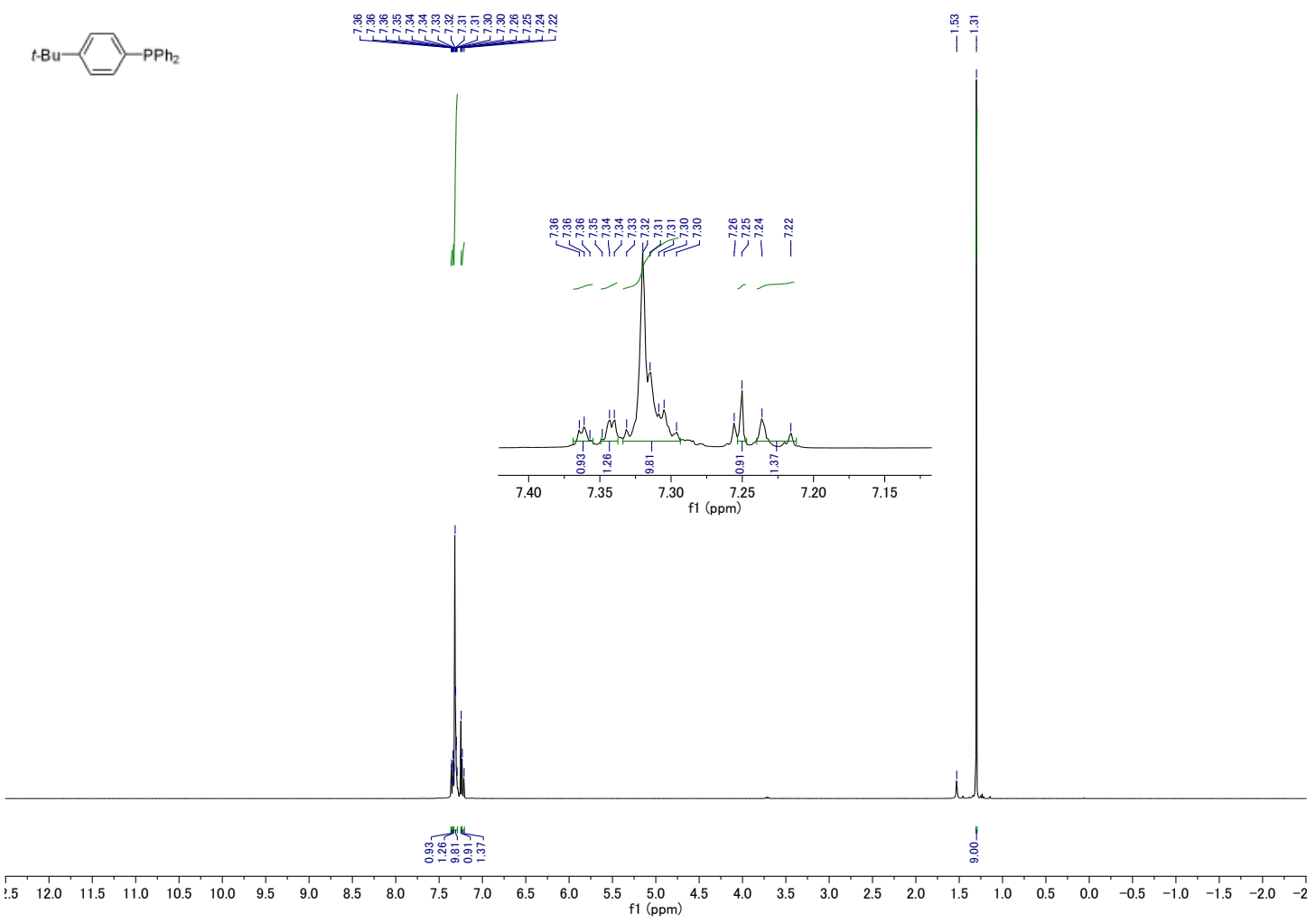


Figure S76: ${ }^{13} \mathrm{C}$ NMR (101 MHz, Chloroform-d) for (4-tert-butylphenyl)diphenylphosphine (2d).
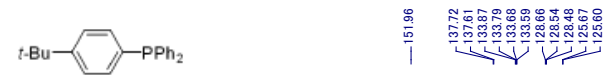

锂量

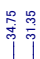

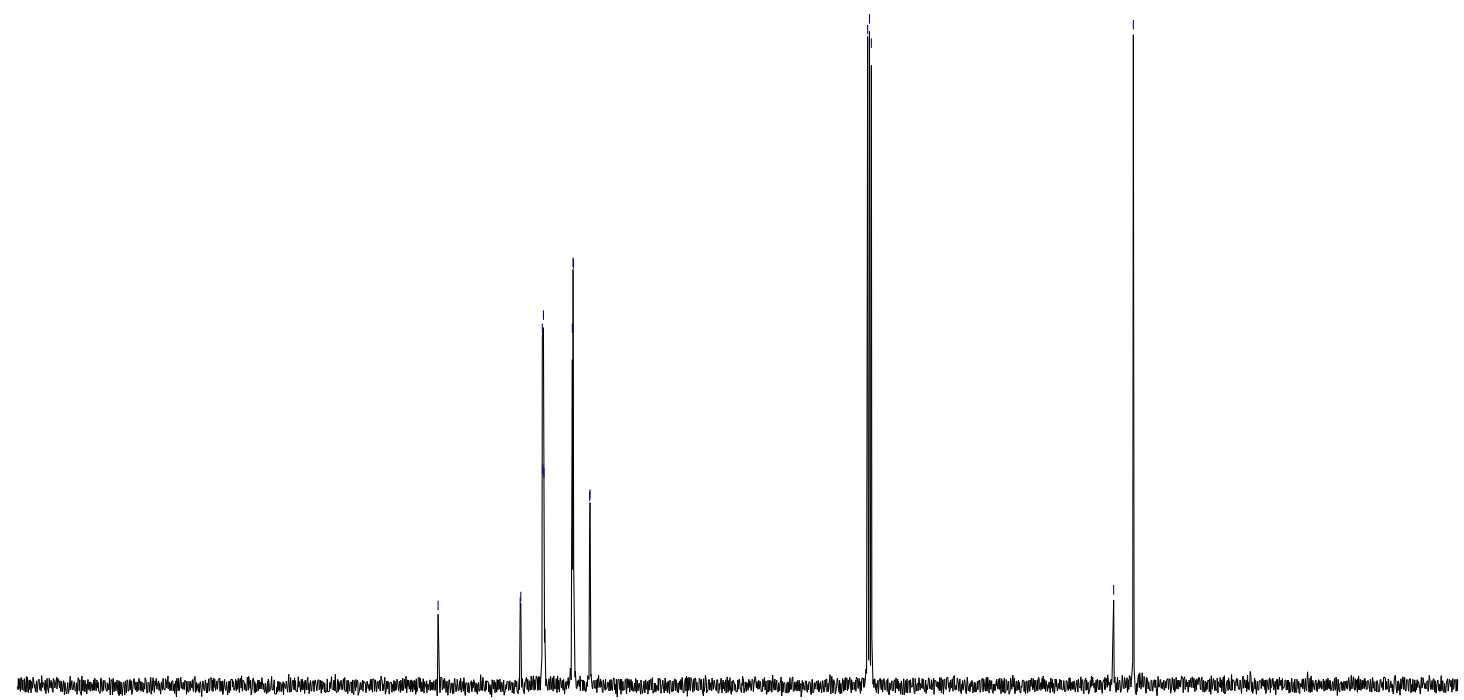

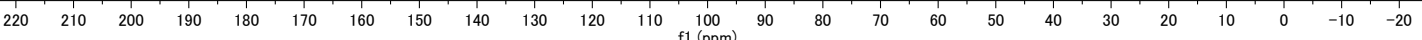

Figure S77: ${ }^{31} \mathrm{P}$ NMR (162 MHz, Chloroform-d) for (4-benzylphenyl)diphenylphosphine (2e). $\mathrm{PhCH}_{2}-\langle\nabla\rangle-\mathrm{PPh}_{2}$ 
Figure S78: ${ }^{1} \mathrm{H}$ NMR (400 MHz, Chloroform-d) for (4-benzylphenyl)diphenylphosphine (2e).

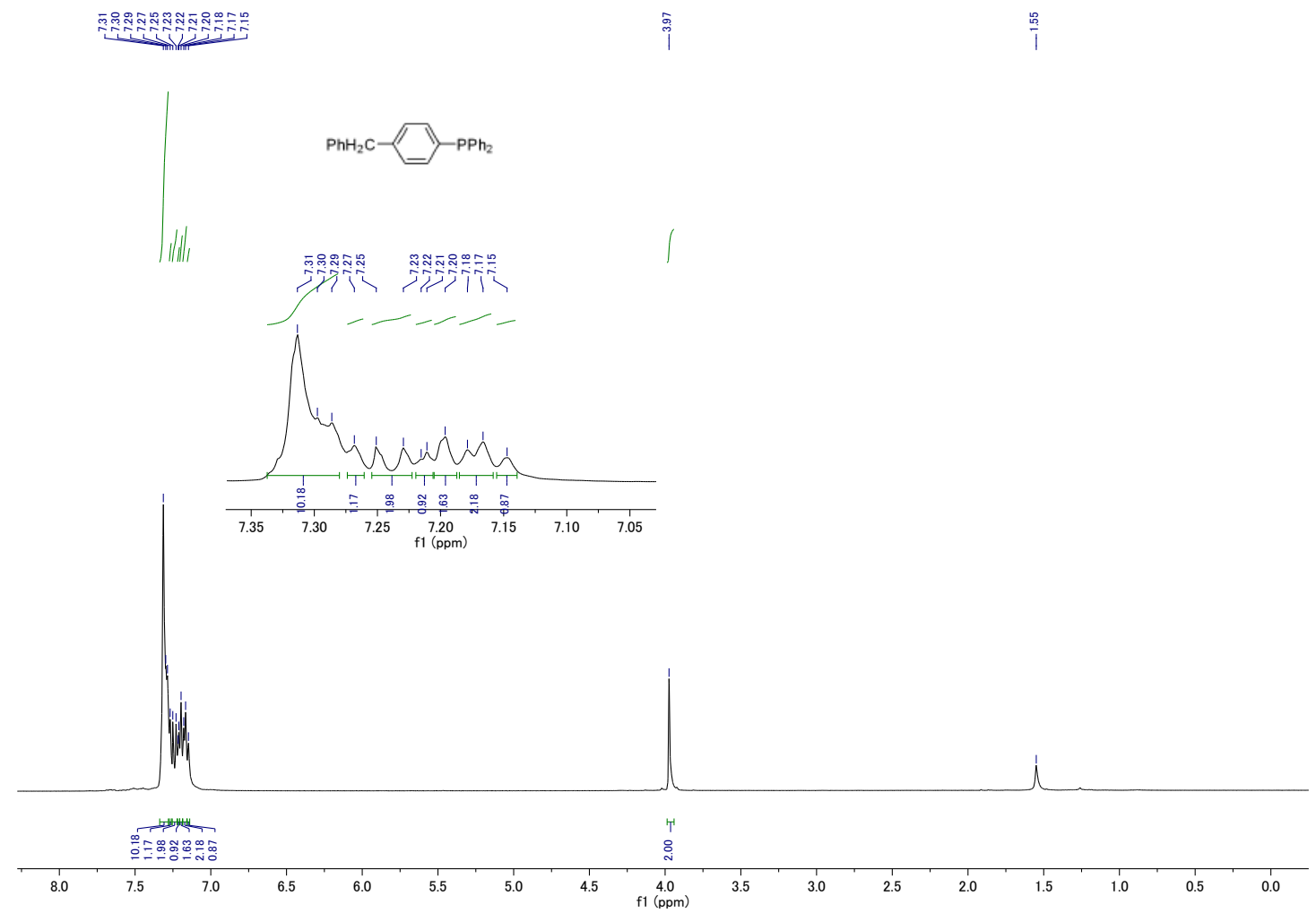

Figure S79: ${ }^{13} \mathrm{C}$ NMR (101 MHz, Chloroform- $d$ ) for (4-benzylphenyl)diphenylphosphine (2e).
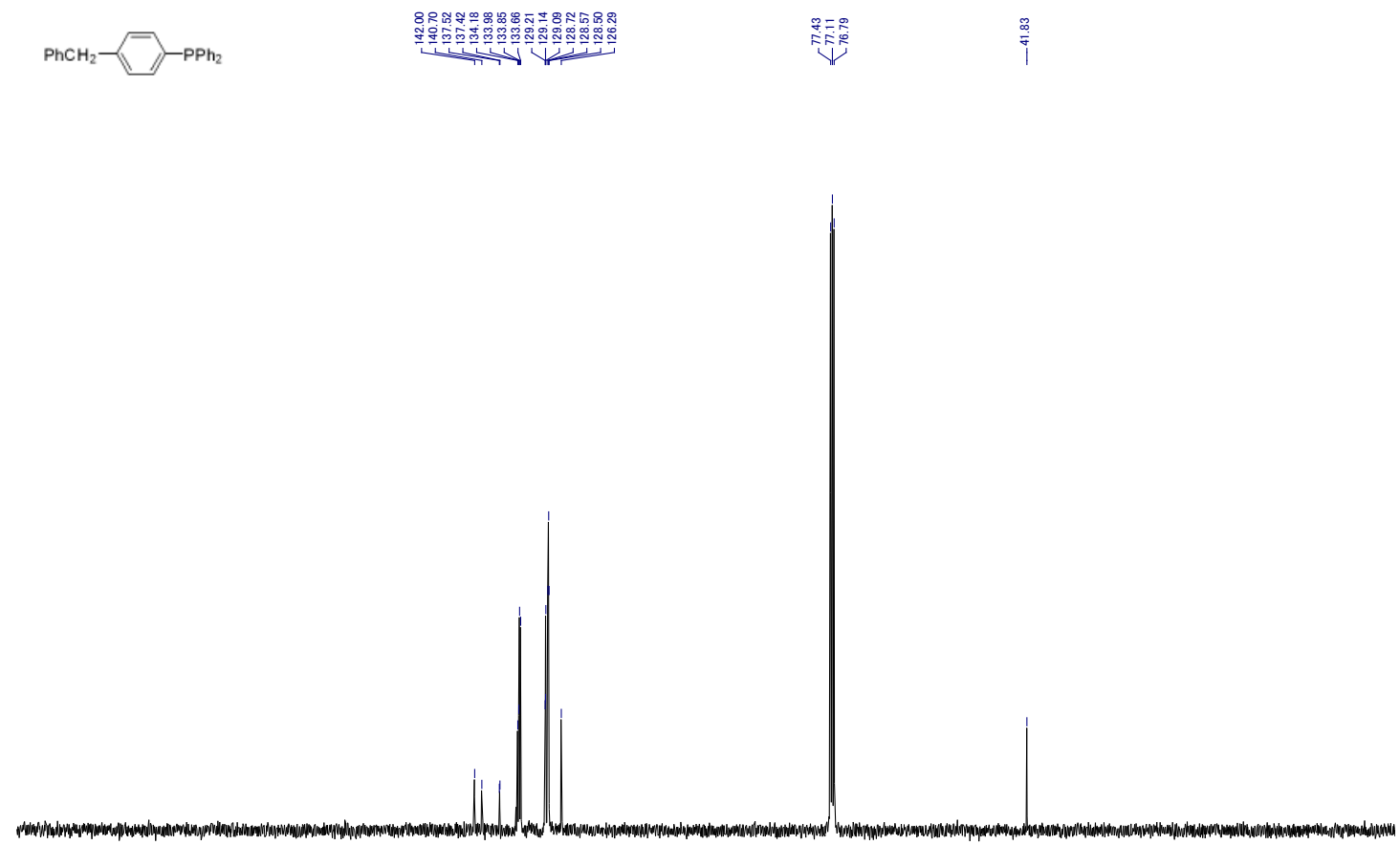

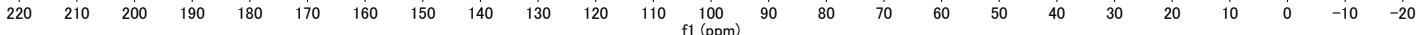


Figure S80: ${ }^{31} \mathrm{P}$ NMR (162 MHz, Chloroform- $d$ ) for (4-tert-butoxyphenyl)diphenylphosphine (2f).<smiles>COc1ccc(C(c2ccccc2)(c2ccccc2)c2ccccc2)cc1</smiles>

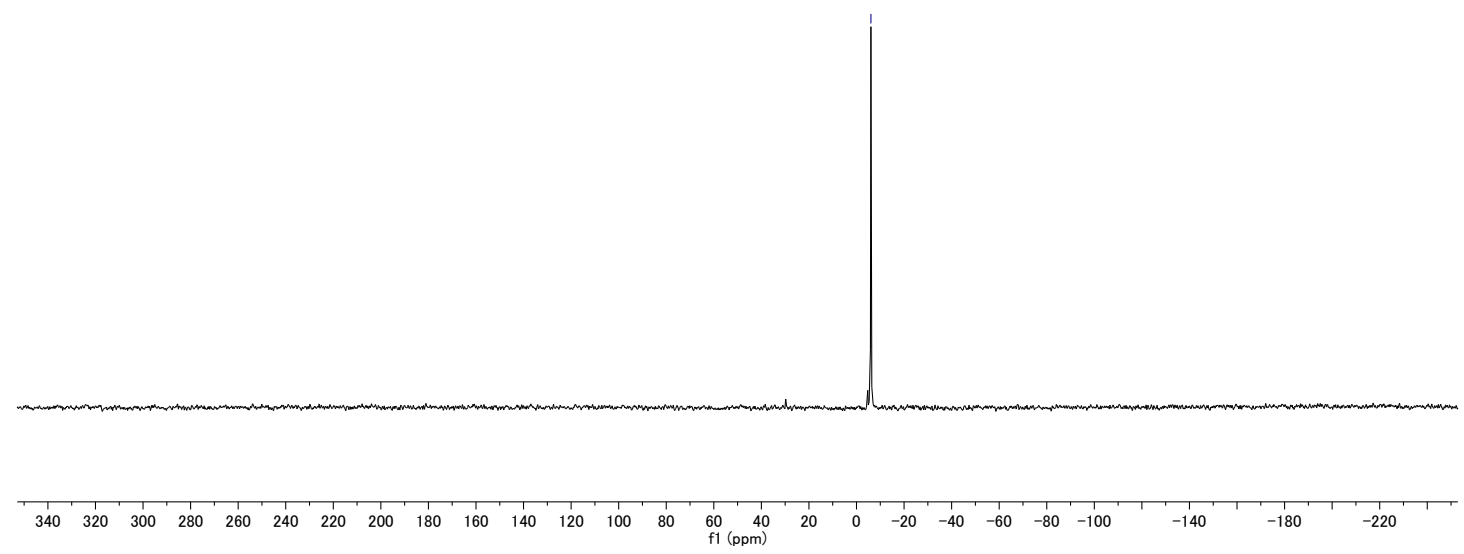

Figure S81: ${ }^{1} \mathrm{H}$ NMR (400 MHz, Chloroform- $d$ ) for (4-tert-butoxyphenyl)diphenylphosphine (2f).

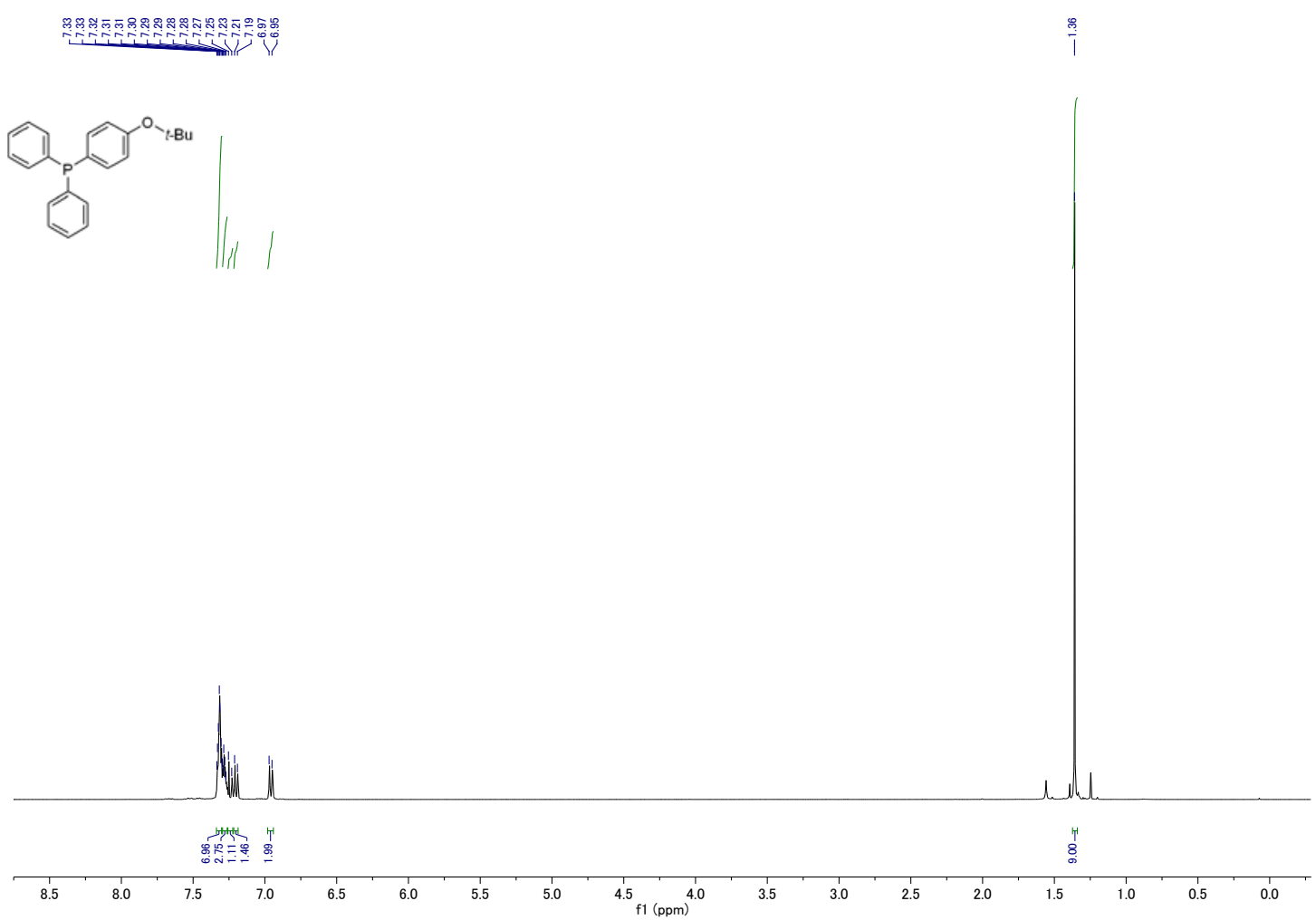


Figure S82: ${ }^{13} \mathrm{C}$ NMR (101 MHz, Chloroform- $d$ ) for (4-tert-butoxyphenyl)diphenylphosphine (2f).

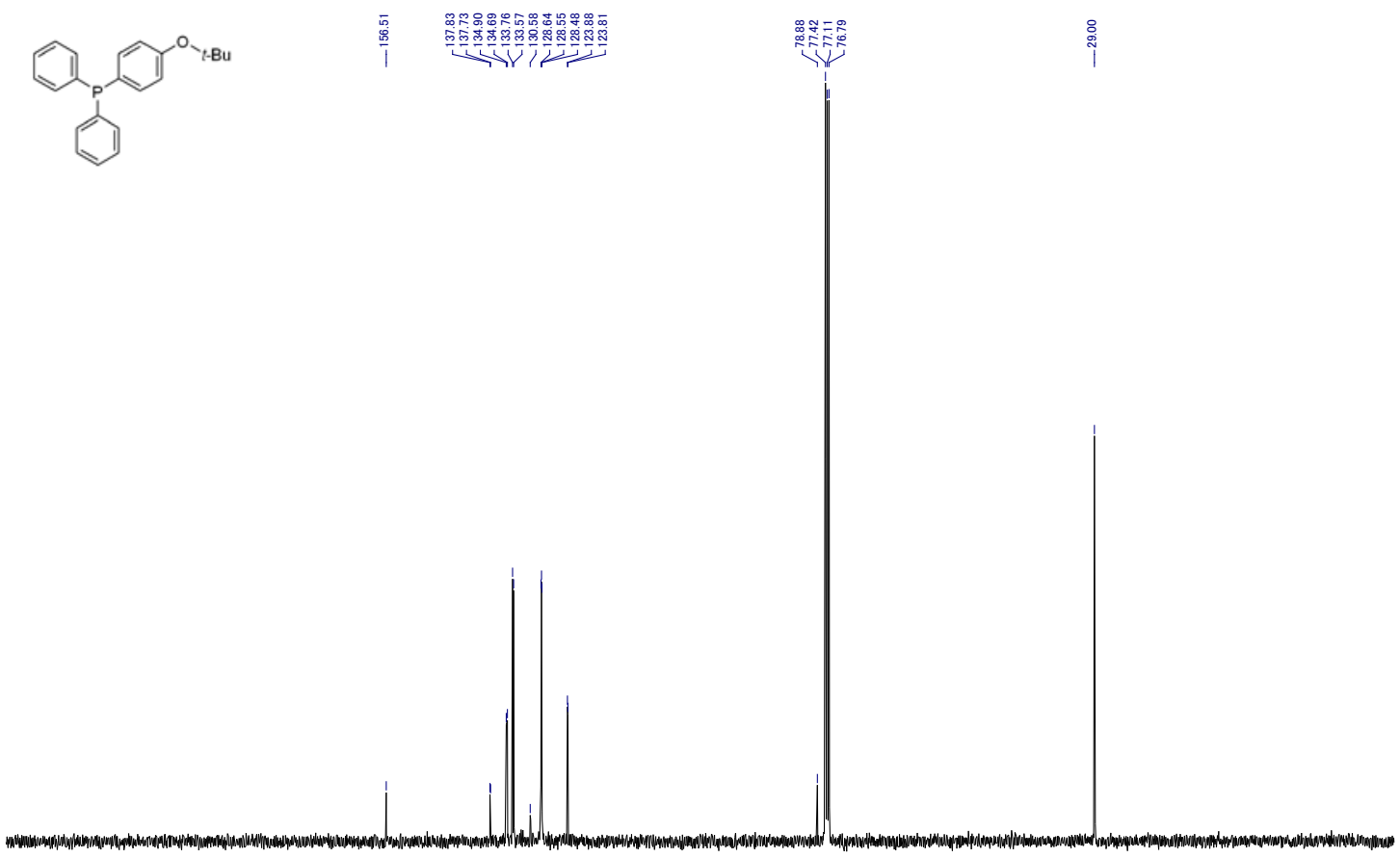

$\begin{array}{llllllllllllllllllllllllllllllllllllllll}1 & 220 & 210 & 200 & 190 & 180 & 170 & 160 & 150 & 140 & 130 & 120 & 110 & 100 & 90 & 80 & 70 & 60 & 50 & 40 & 30 & 20 & 10 & 0 & -10 & -20\end{array}$

Figure S83: ${ }^{31} \mathrm{P}$ NMR (162 MHz, Chloroform- $d$ ) for diphenyl(4-phenoxyphenyl)phosphine (2g).
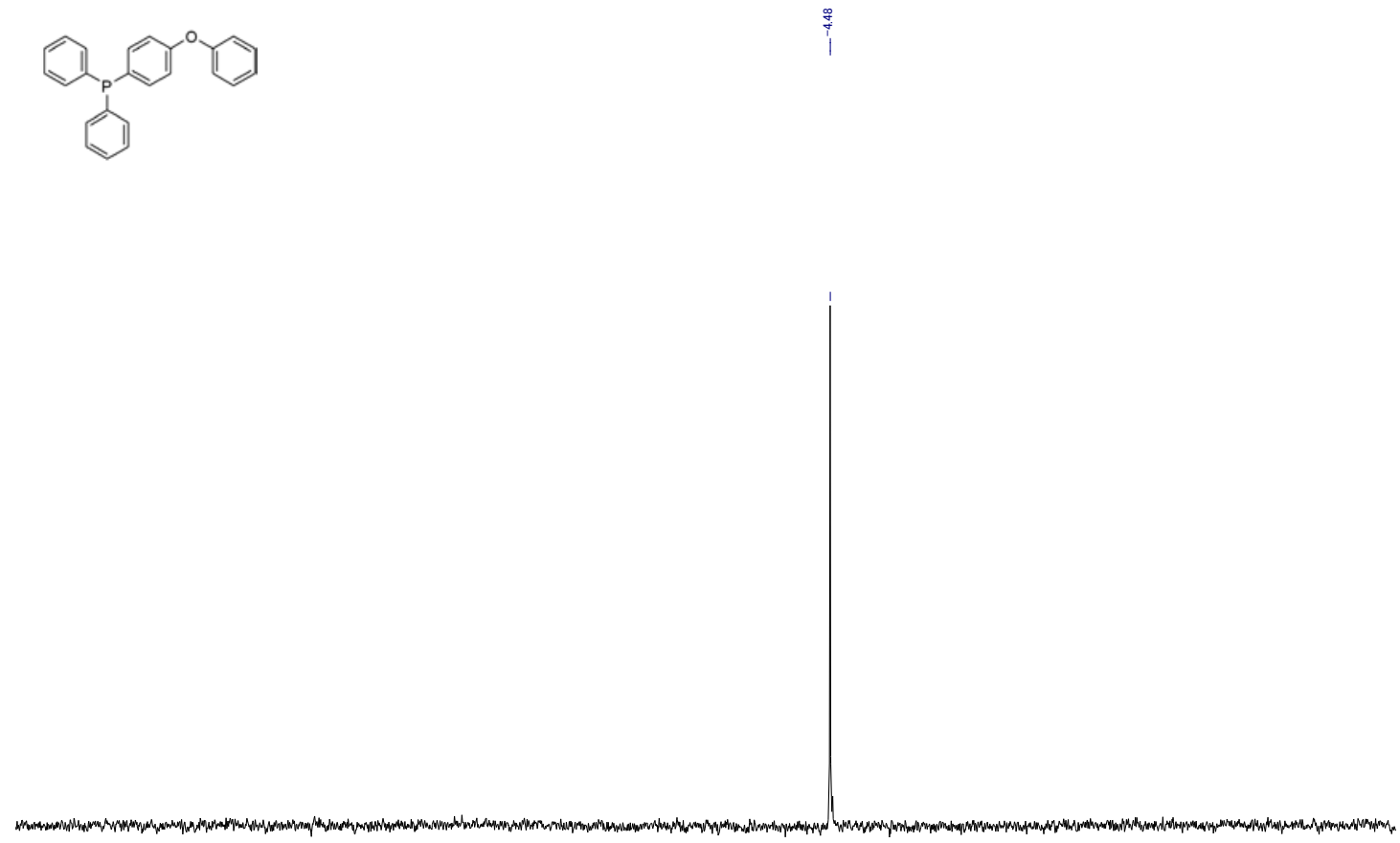

$\begin{array}{llllllllllllllllllllllllllllll}340 & 320 & 300 & 280 & 260 & 240 & 220 & 200 & 180 & 160 & 140 & 120 & 100 & 80 & 60 & 40 & 20 & 0 & -20 & -40 & -60 & -80 & -100 & -140 & -180 & -220 & \end{array}$ 
Figure S84: ${ }^{1} \mathrm{H}$ NMR (400 MHz, Chloroform- $d$ ) for diphenyl(4-phenoxyphenyl)phosphine (2g).

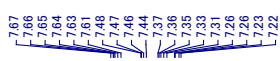

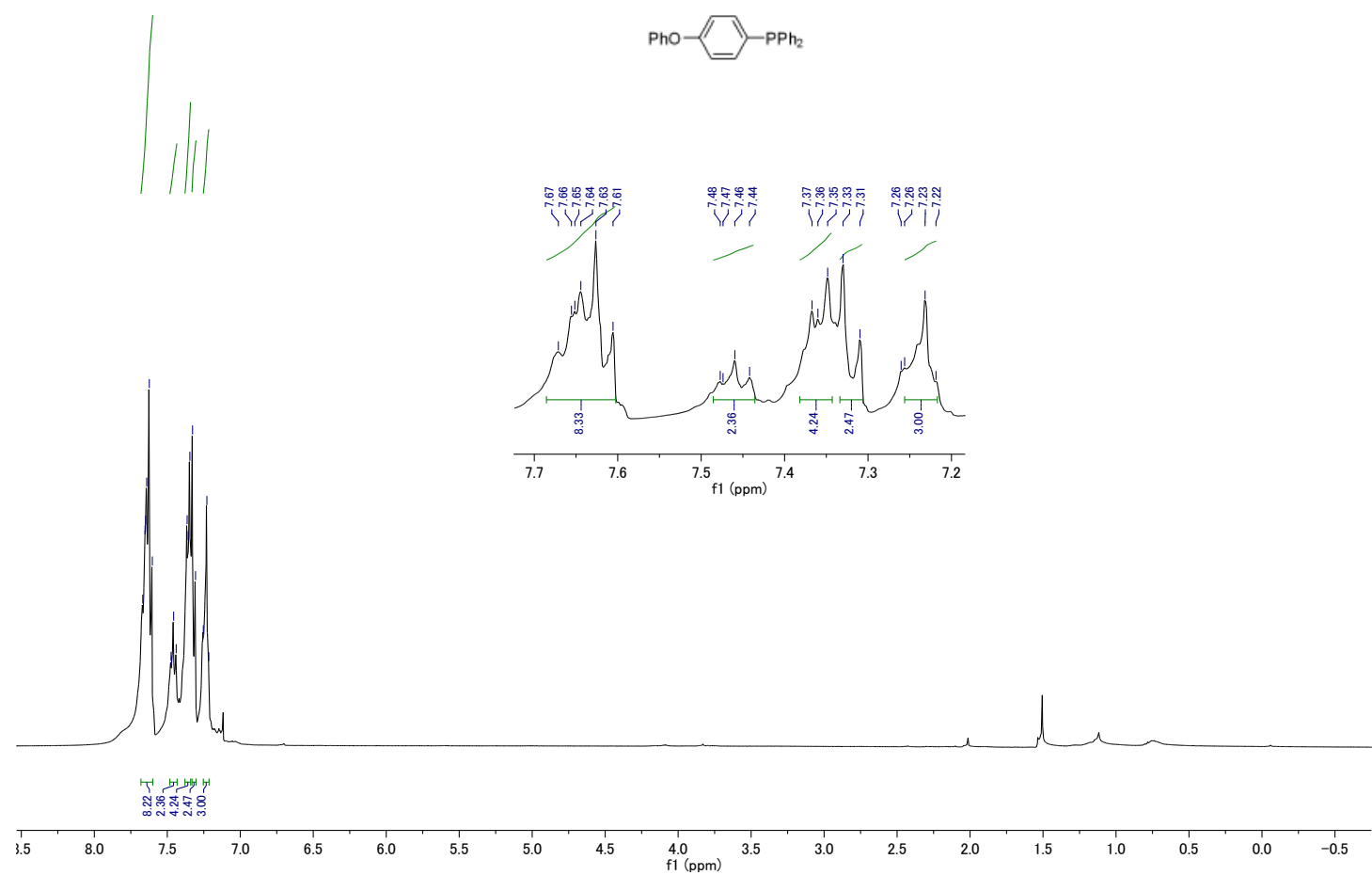

Figure S85: ${ }^{31}$ P NMR (162 MHz, Chloroform- $d$ ) for diphenyl(4-phenoxyphenyl)phosphine (2g).

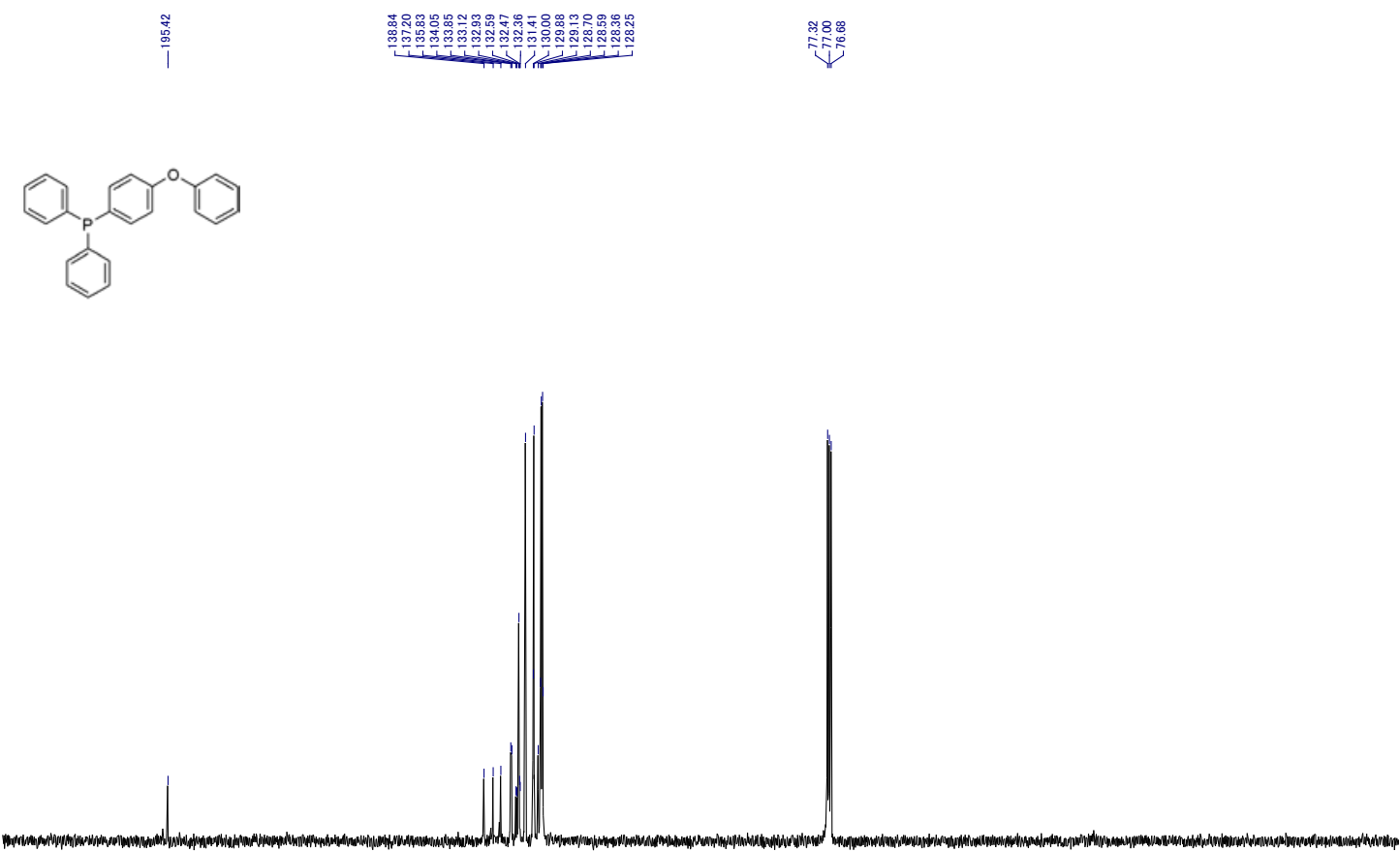

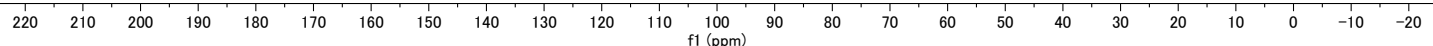


Figure S86: ${ }^{31} \mathrm{P}$ NMR (162 MHz, Chloroform-d) for methyl (4-diphenylphosphino)benzoic acid (2h).
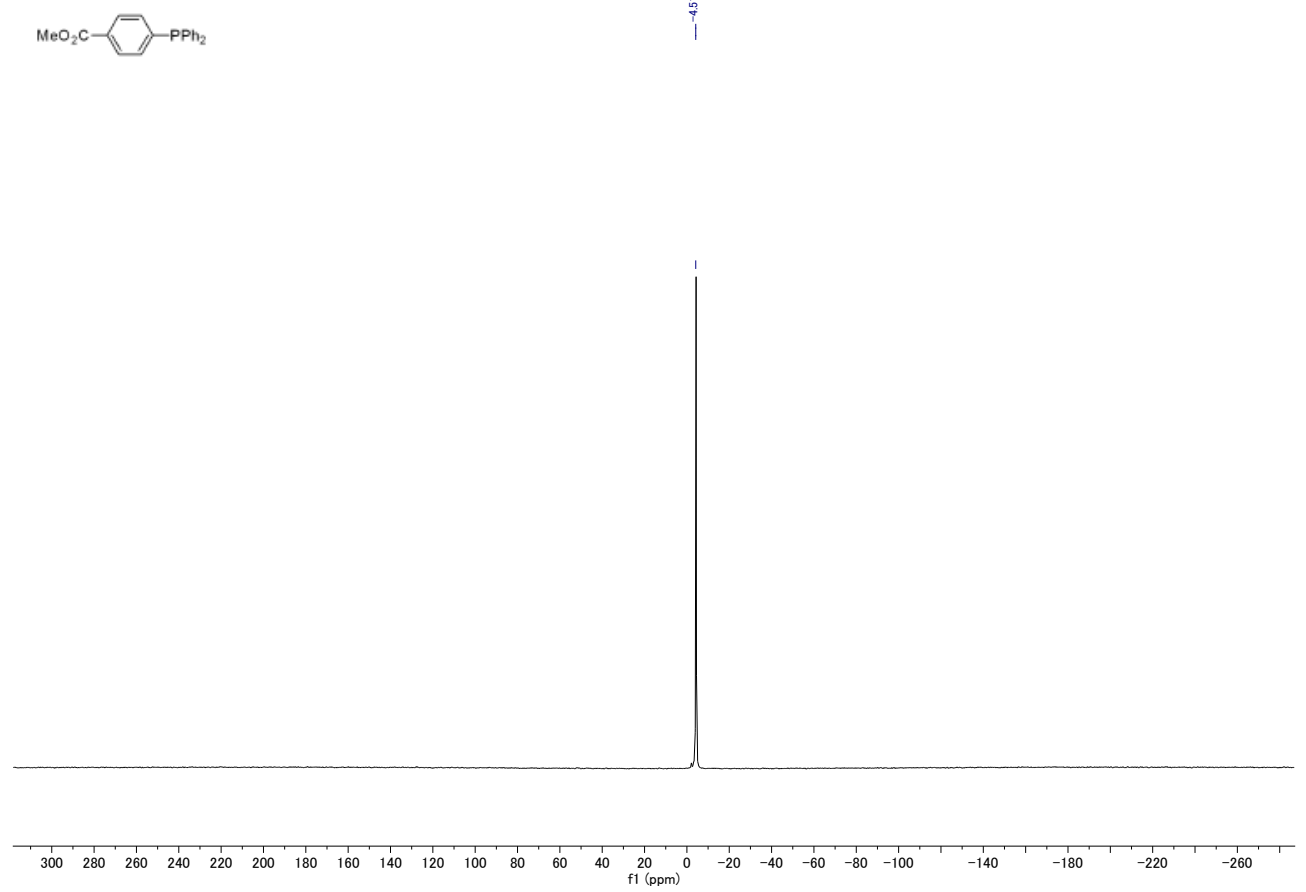

Figure S87: ${ }^{1} \mathrm{H}$ NMR (400 MHz, Chloroform-d) for methyl (4-diphenylphosphino)benzoic acid (2h).
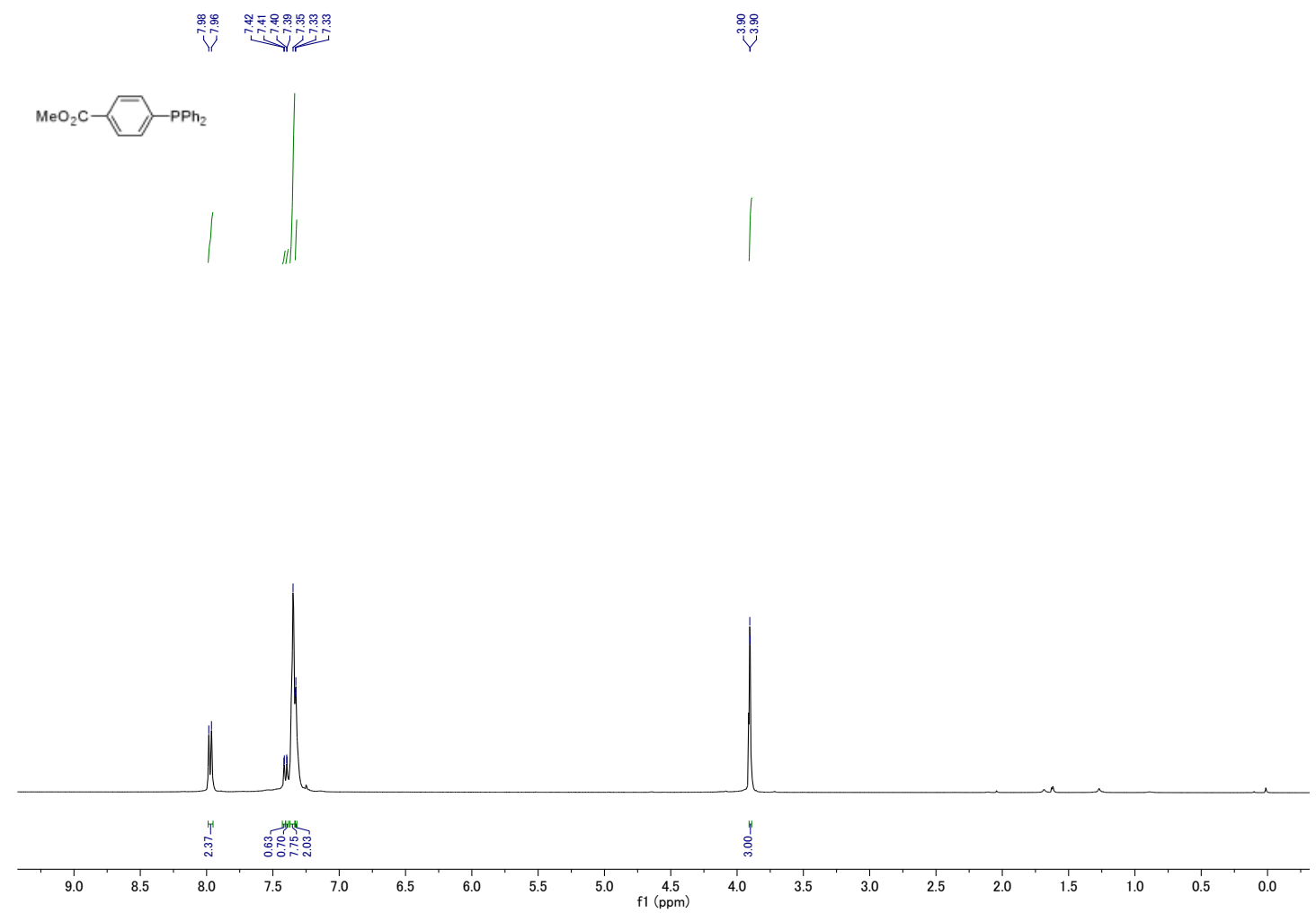
Figure S88: ${ }^{13} \mathrm{C}$ NMR (101 MHz, Chloroform-d) for methyl (4-diphenylphosphino)benzoic acid (2h).
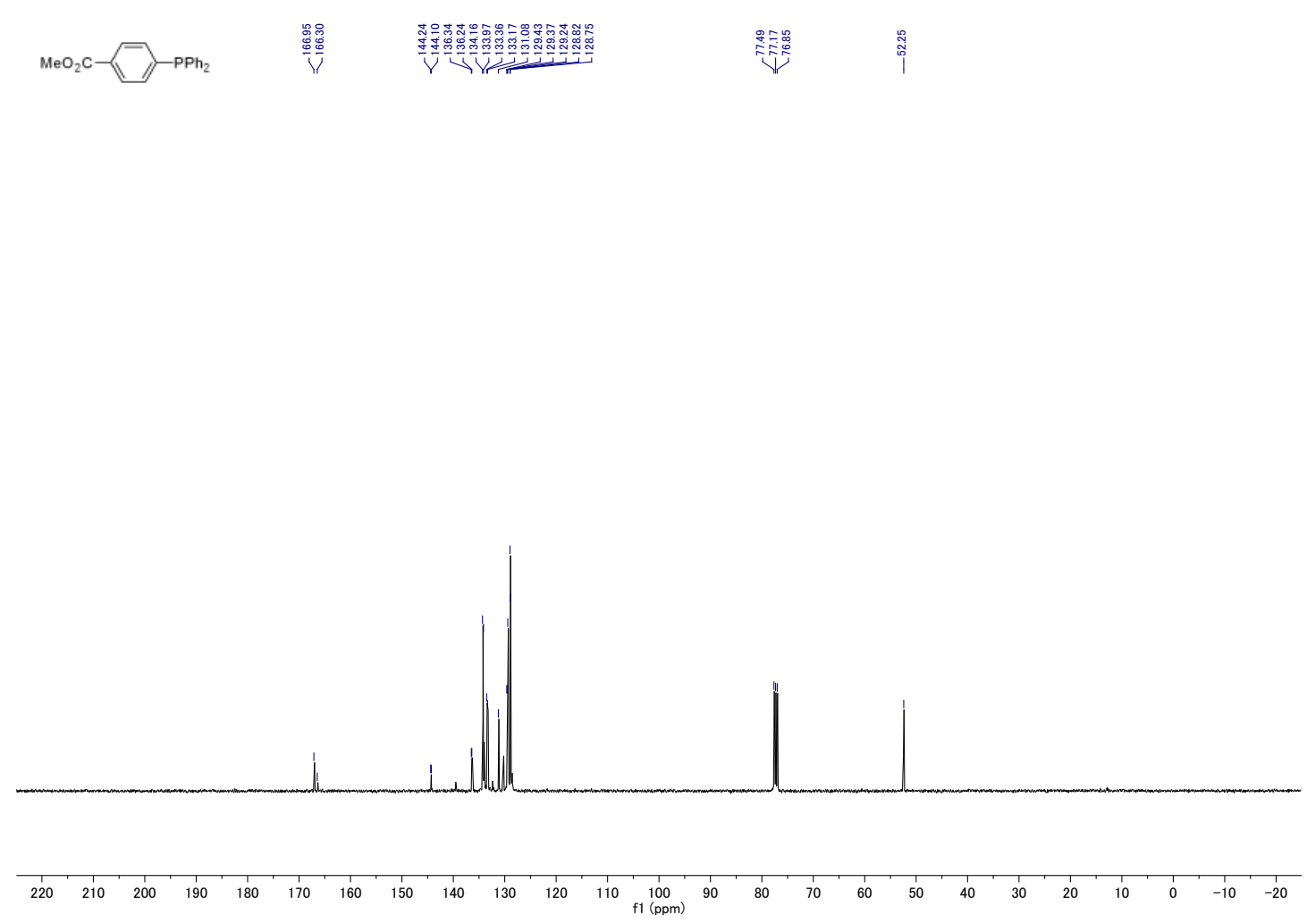

Figure $\quad$ S89: $\quad{ }^{31} \mathrm{P} \quad$ NMR $\quad(162 \quad \mathrm{MHz}, \quad$ Chloroform- $d) \quad$ for dipheny(4-trifluoromethylphenyl)lphosphine(2i).
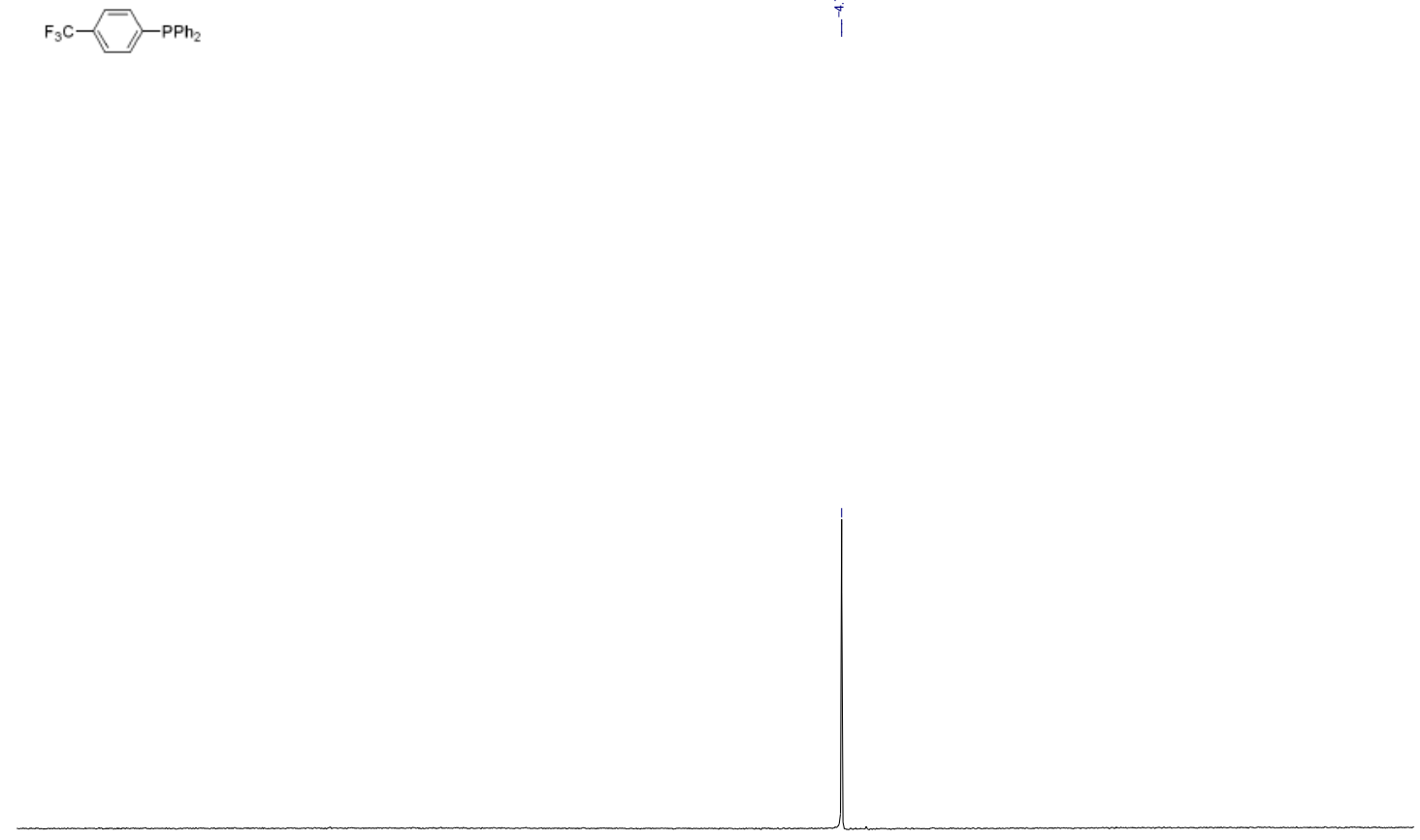

\begin{tabular}{llllllllllllllllllllllllllllllll}
\hline 340 & 320 & 300 & 280 & 260 & 240 & 220 & 200 & 180 & 160 & 140 & 120 & 100 & 80 & 60 & 40 & 20 & 0 & -20 & -40 & -60 & -80 & -100 & -140 & -180 & -220 &
\end{tabular} 
Figure S90: $\quad{ }^{1} \mathrm{H} \quad$ NMR $\quad(400 \quad \mathrm{MHz}, \quad$ Chloroform- $d) \quad$ for dipheny(4-trifluoromethylphenyl)lphosphine(2i).

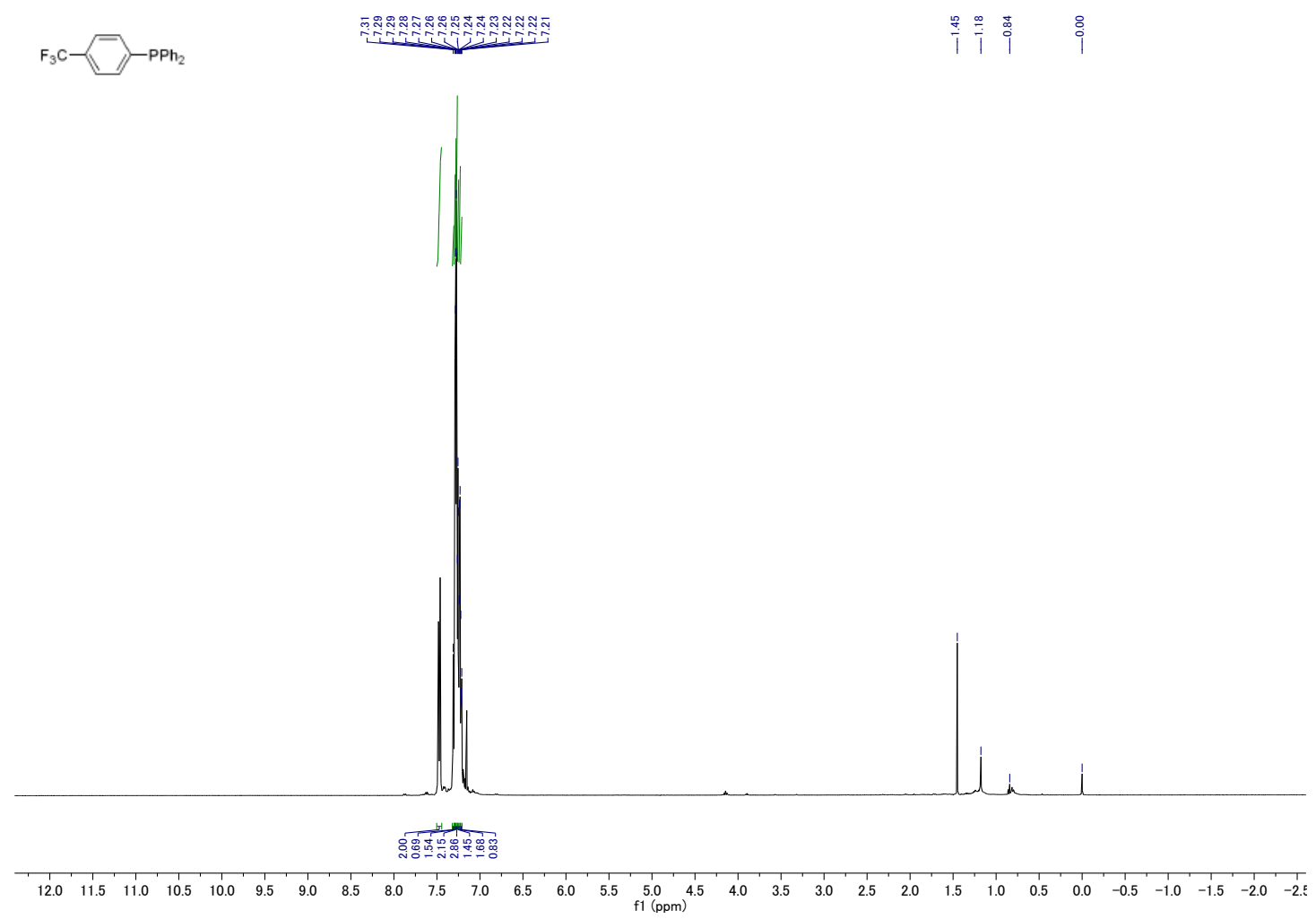

Figure S91: ${ }^{13} \mathrm{C}$ NMR (101 MHz, Chloroform- $d$ ) for dipheny(4-trifluoromethylphenyl)lphosphine (2i).
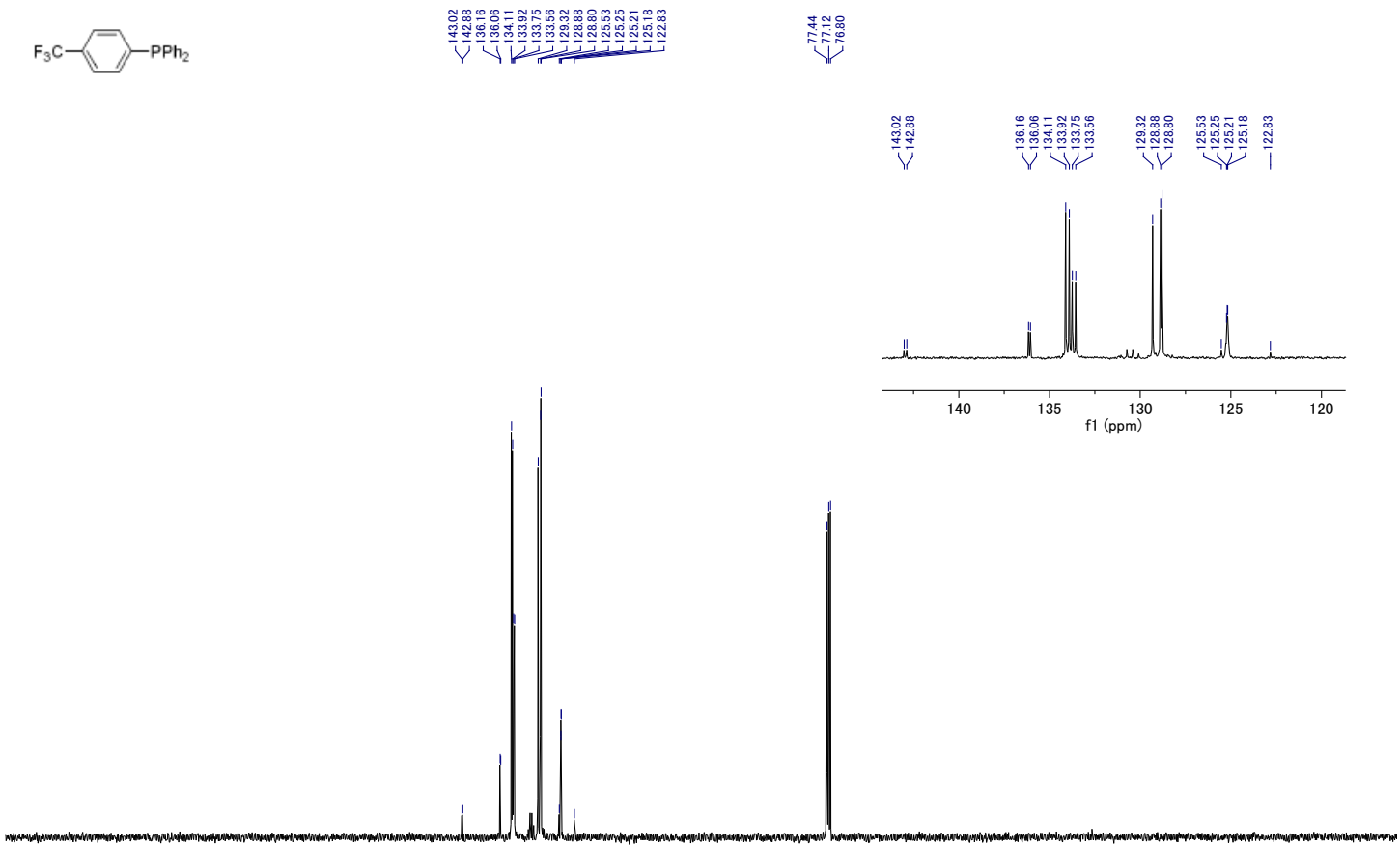

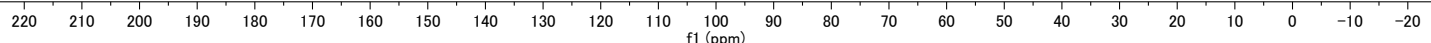


Figure S92: ${ }^{31} \mathrm{P}$ NMR (162 MHz, Chloroform-d) for (4-diphenylphosphino)benzonitrile (2j). $\mathrm{NC}-\longrightarrow \mathrm{PPh}_{2}$

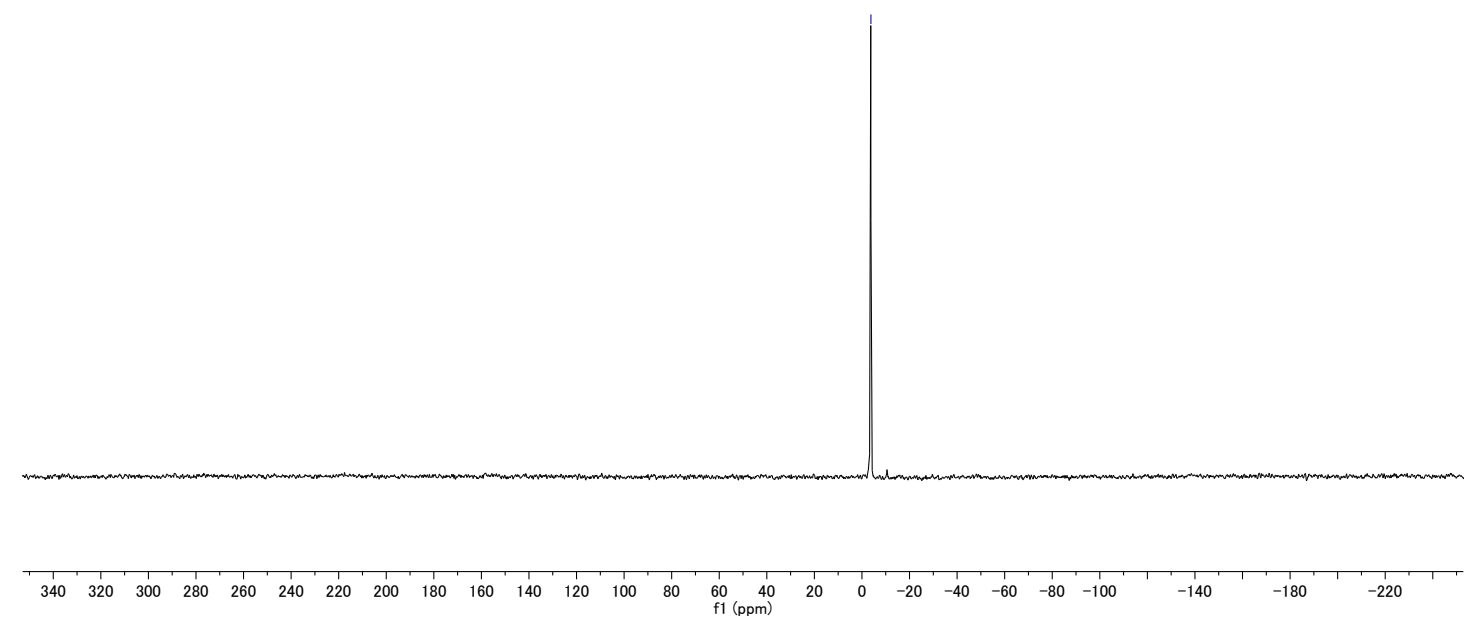

Figure S93: ${ }^{1} \mathrm{H}$ NMR (400 MHz, Chloroform- $d$ ) for (4-diphenylphosphino)benzonitrile (2j).

鲁

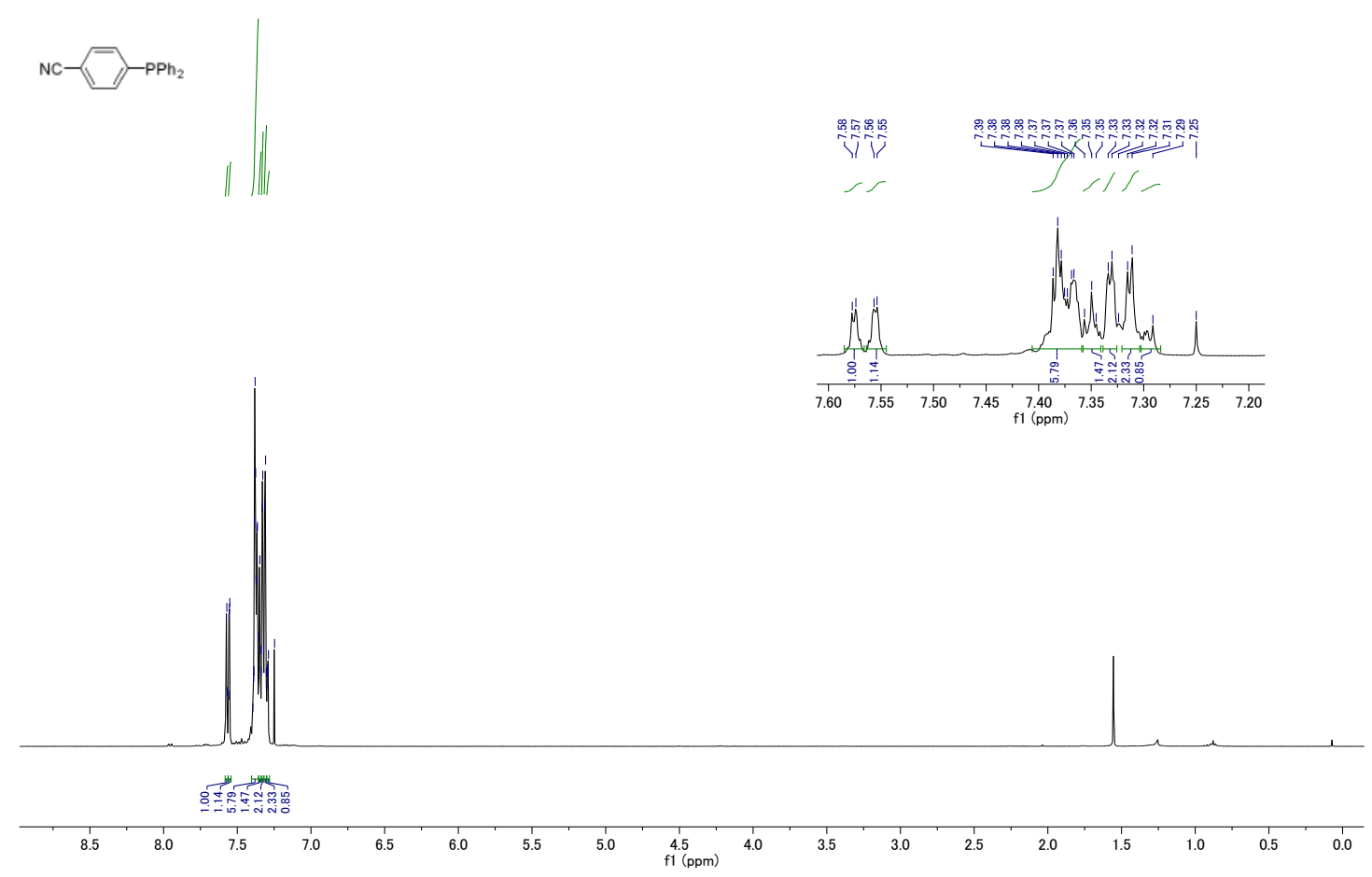


Figure S94: ${ }^{13} \mathrm{C}$ NMR (101 MHz, Chloroform-d) for (4-diphenylphosphino)benzonitrile (2j).
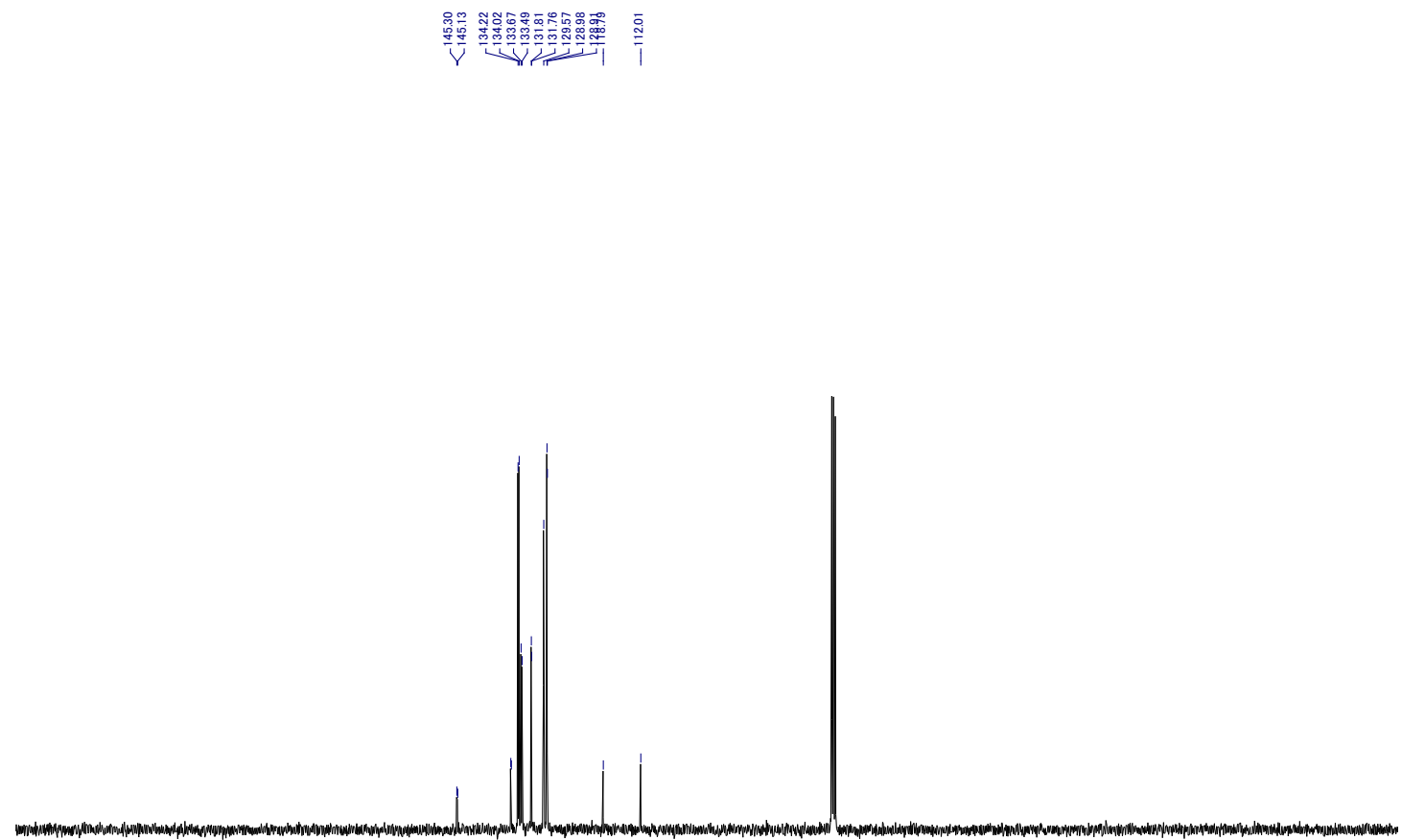

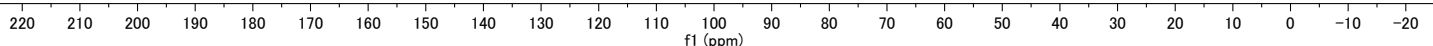

Figure S95: ${ }^{31} \mathrm{P}$ NMR (162 MHz, Chloroform- $d$ ) for 1-naphthyl diphenyl(1-naphthyl)phosphine (2k).
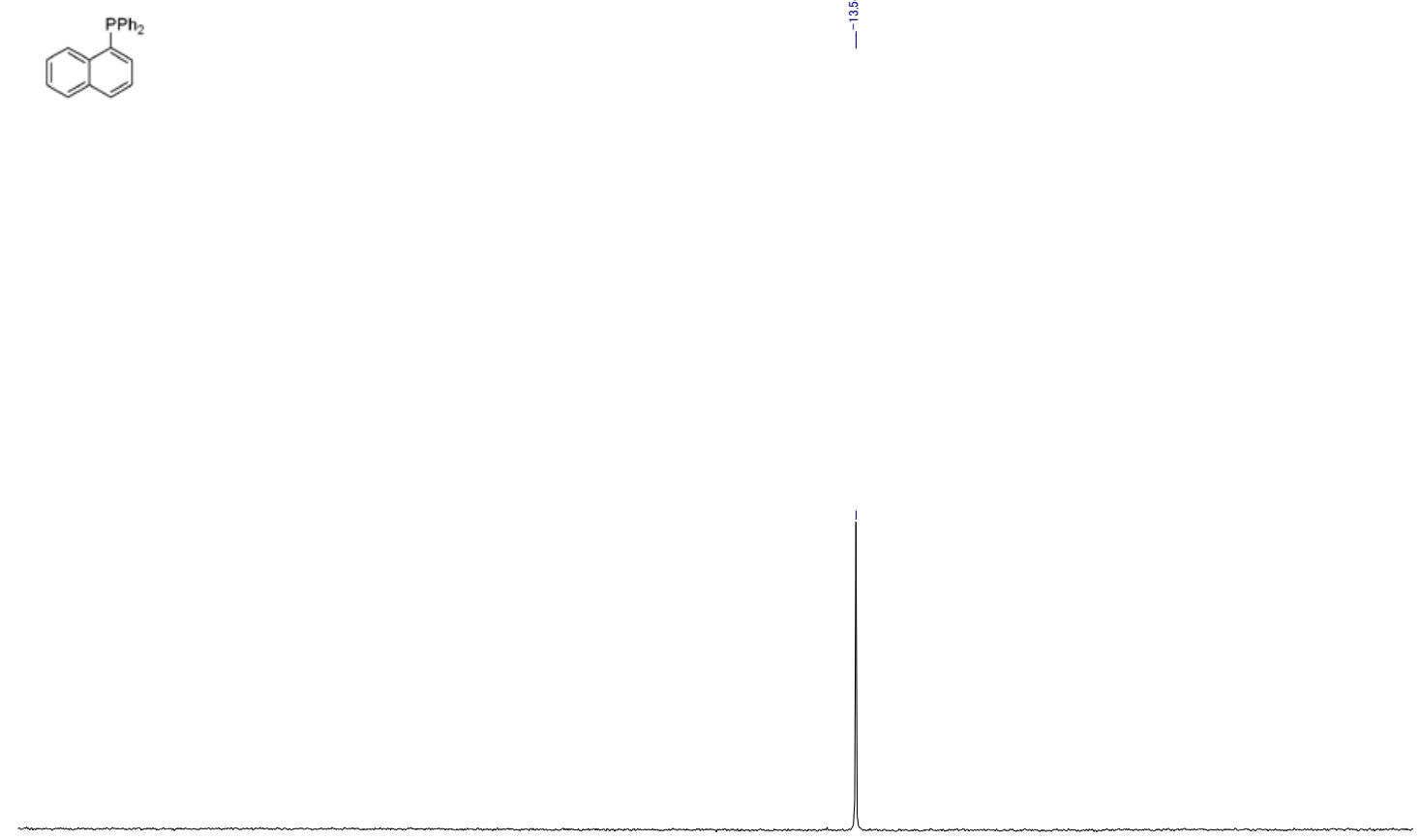

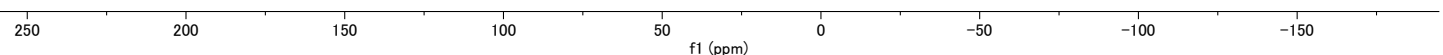


Figure S96: ${ }^{1} \mathrm{H}$ NMR (400 MHz, Chloroform- $d$ ) for diphenyl(1-naphthyl)phosphine

$(2 \mathbf{k})$.

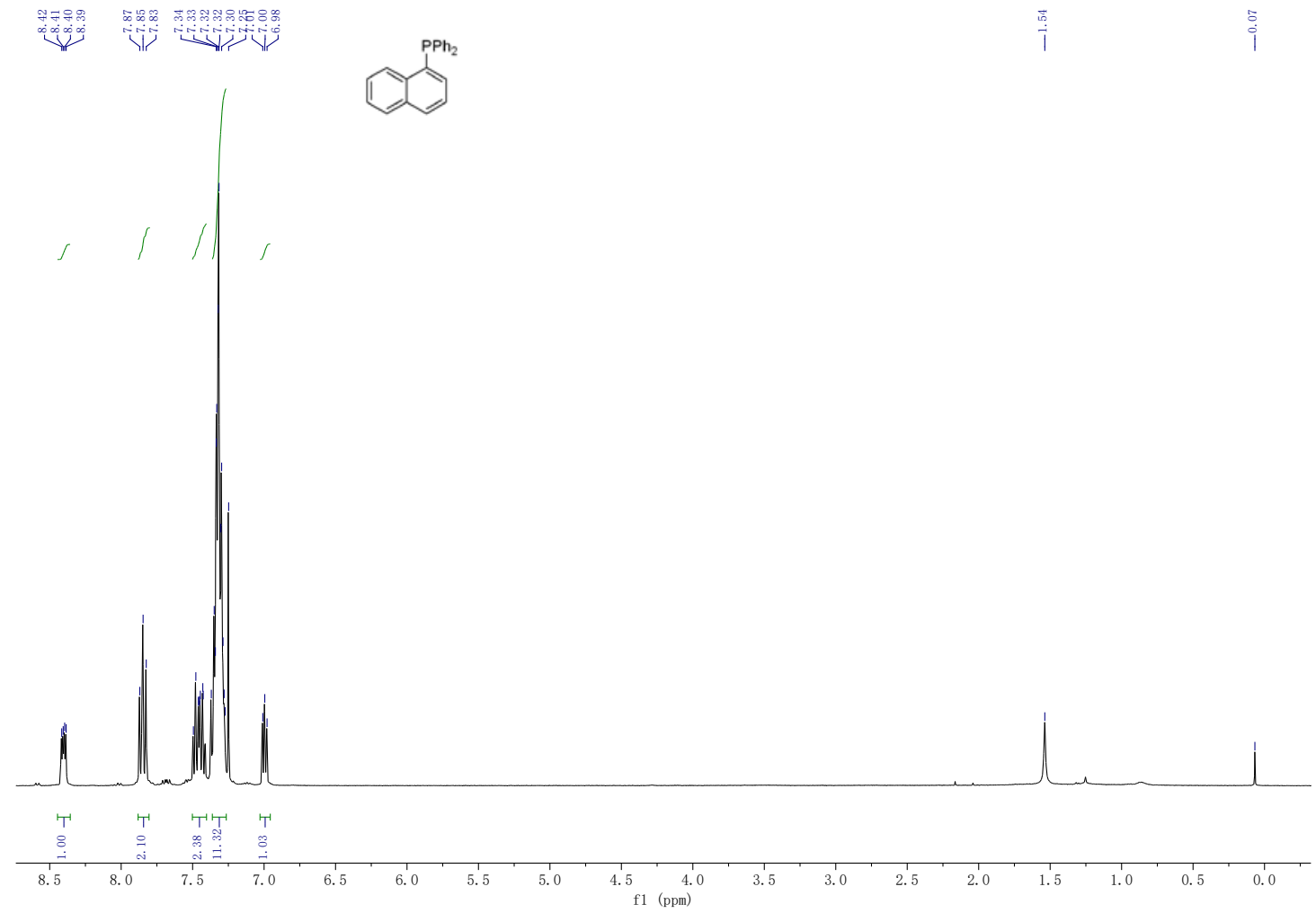

Figure S97: ${ }^{13} \mathrm{C}$ NMR (101 MHz, Chloroform- $d$ ) for diphenyl(1-naphthyl)phosphine (2k).
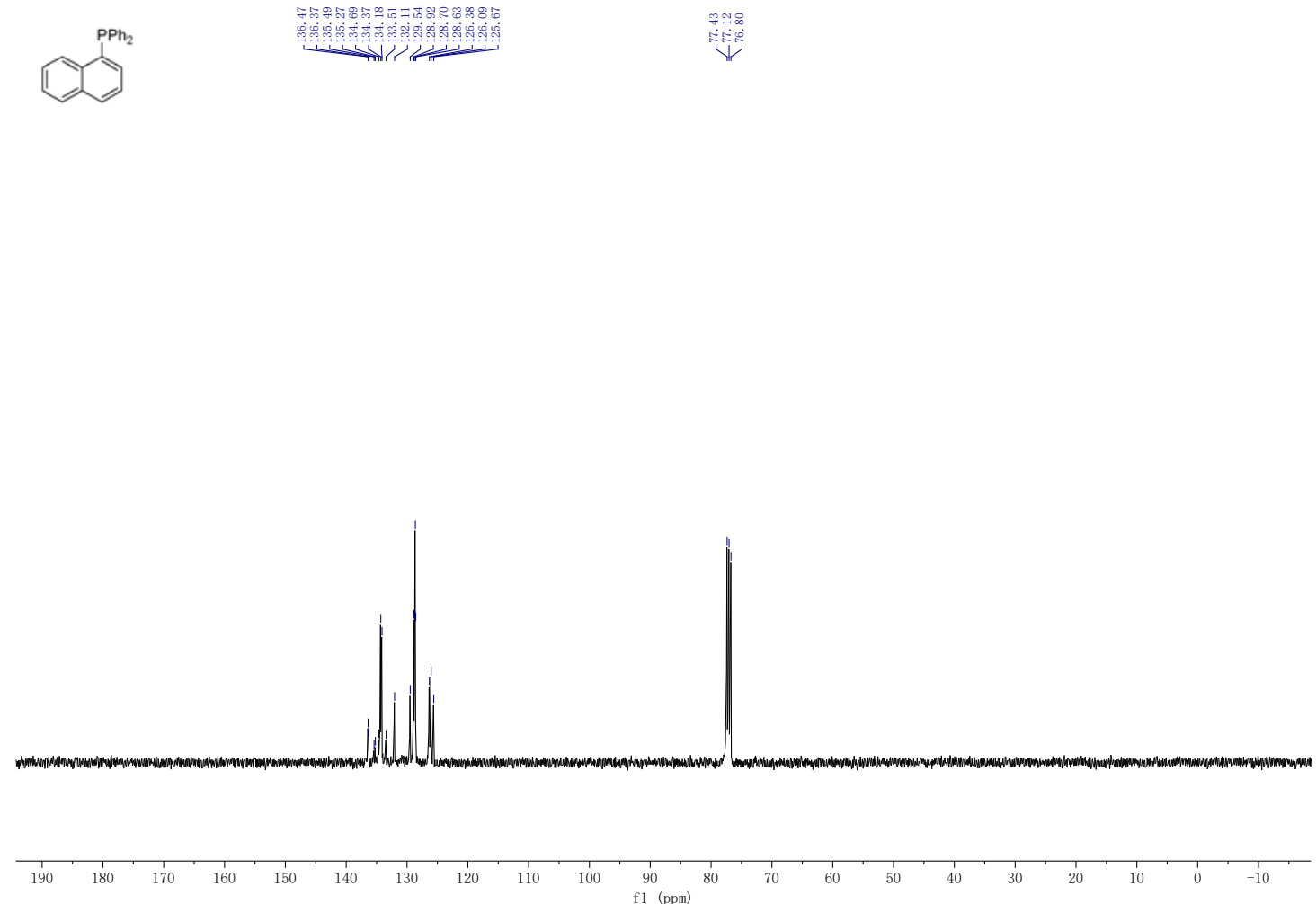
Figure S98: ${ }^{31} \mathrm{P}$ NMR (162 MHz, Chloroform- $d$ ) for diphenyl(2-naphthyl)phosphine (2l).
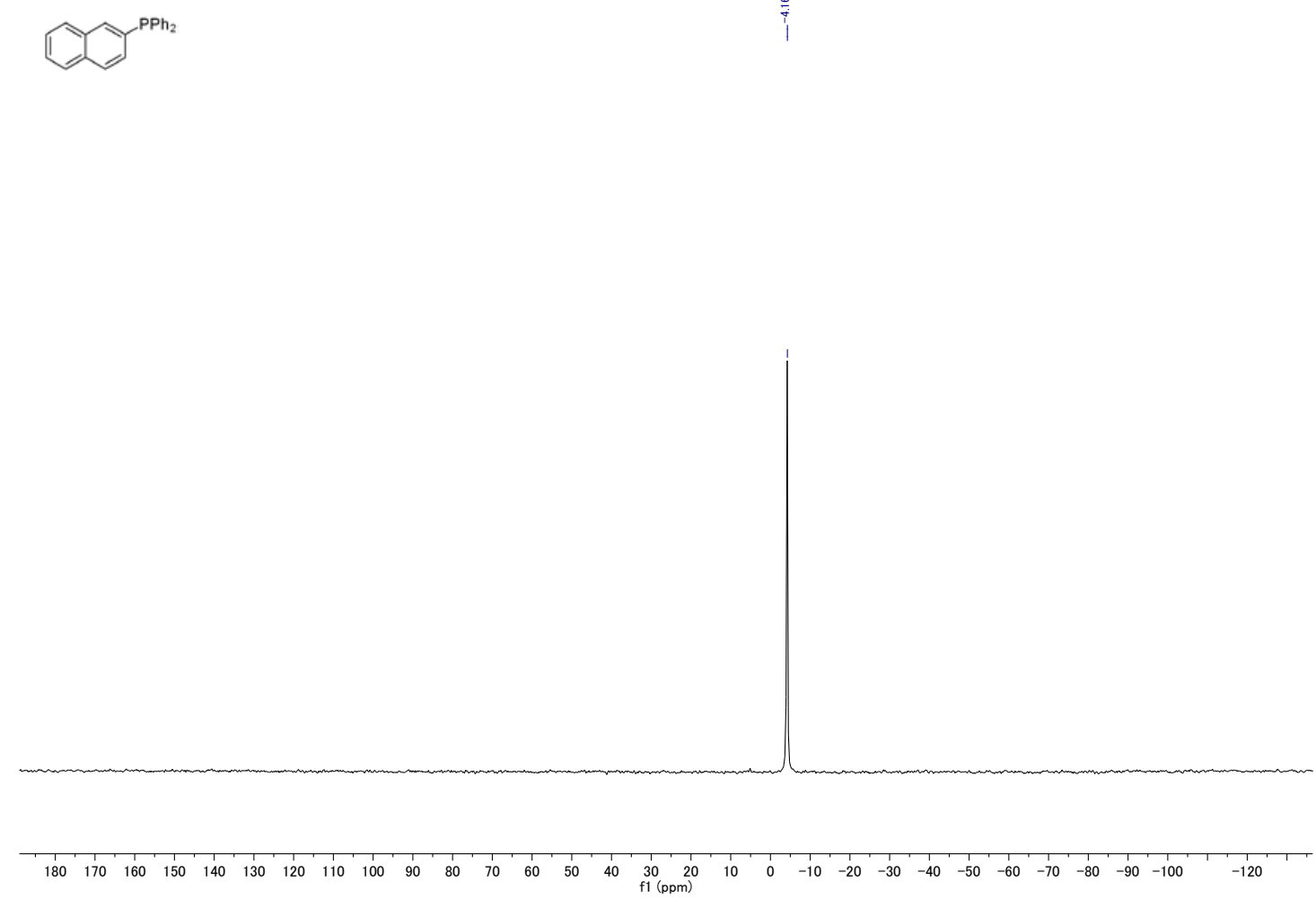

Figure S99: ${ }^{1} \mathrm{H}$ NMR (400 MHz, Chloroform-d) for diphenyl(2-naphthyl)phosphine (2l).

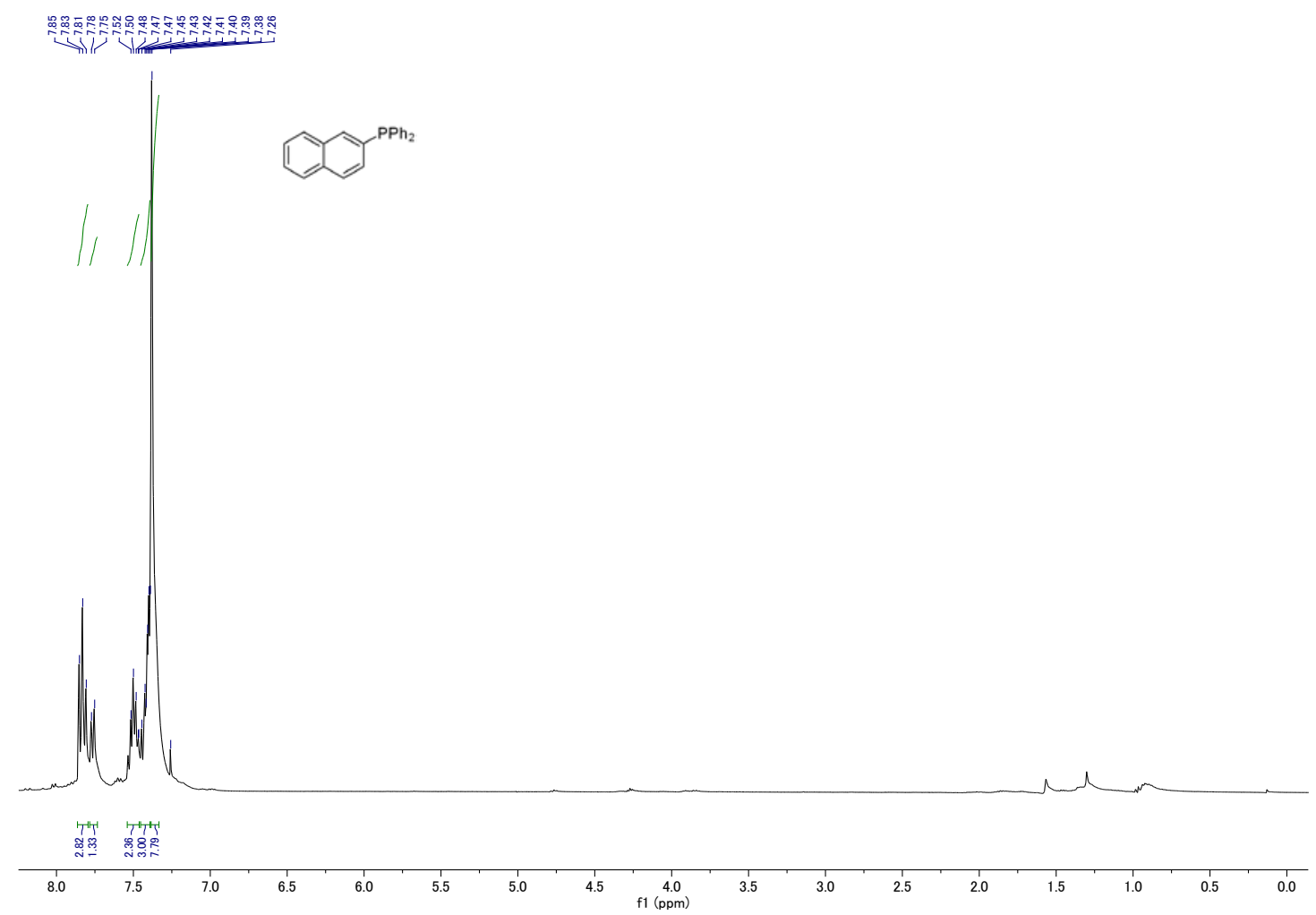


Figure S100: ${ }^{13} \mathrm{C}$ NMR (101 MHz, Chloroform-d) for diphenyl(2-naphthyl)phosphine (2l).

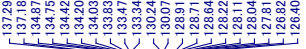
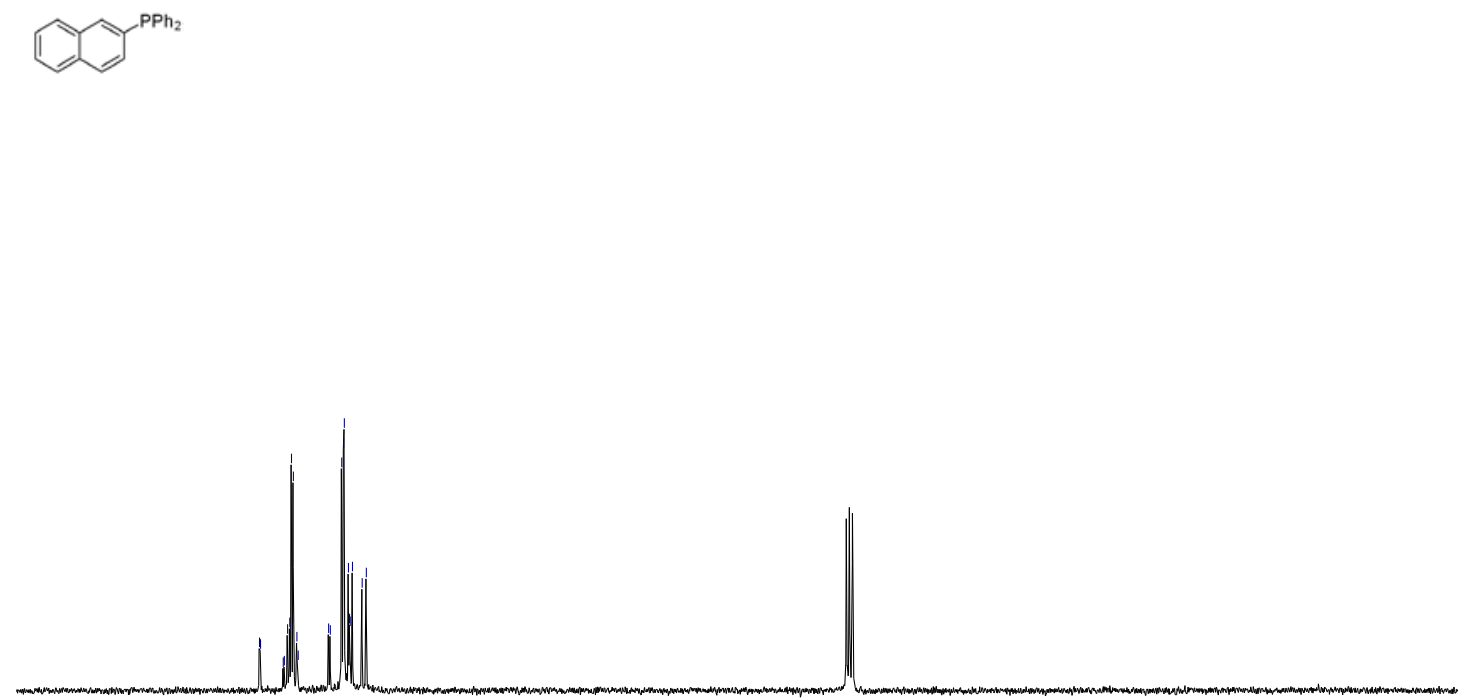

$\begin{array}{llllllllllllllllllllllllllllllllllllllll}160 & 155 & 150 & 145 & 140 & 135 & 130 & 125 & 120 & 115 & 110 & 105 & 100 & 95 & 90 & 85 & 80 & 75 & 70 & 65 & 60 & 55 & 50 & 45 & 40 & 35 & 30 & 25 & 20\end{array}$

Figure S101: ${ }^{31}$ P NMR (162 MHz, Chloroform- $d$ ) for (2-diphenylphosphino)pyridine (2m).

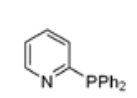

$$
\text { 䗆 }
$$

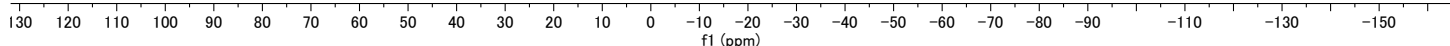


Figure S102: ${ }^{1} \mathrm{H}$ NMR (400 MHz, Chloroform- $d$ ) for (2-diphenylphosphino)pyridine (2m).

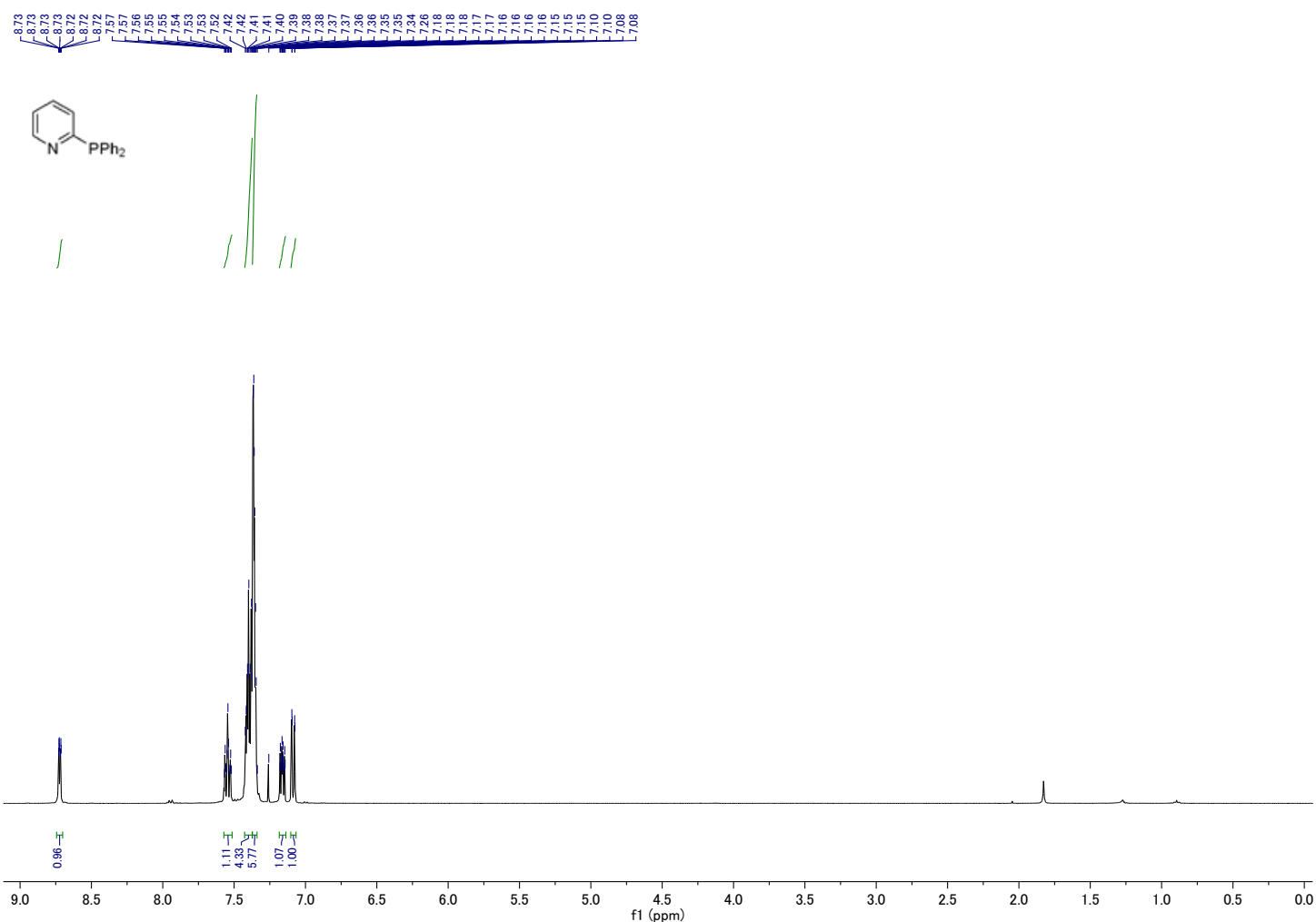

Figure S103: ${ }^{13} \mathrm{C}$ NMR (101 MHz, Chloroform- $d$ ) for (2-diphenylphosphino)pyridine (2m).

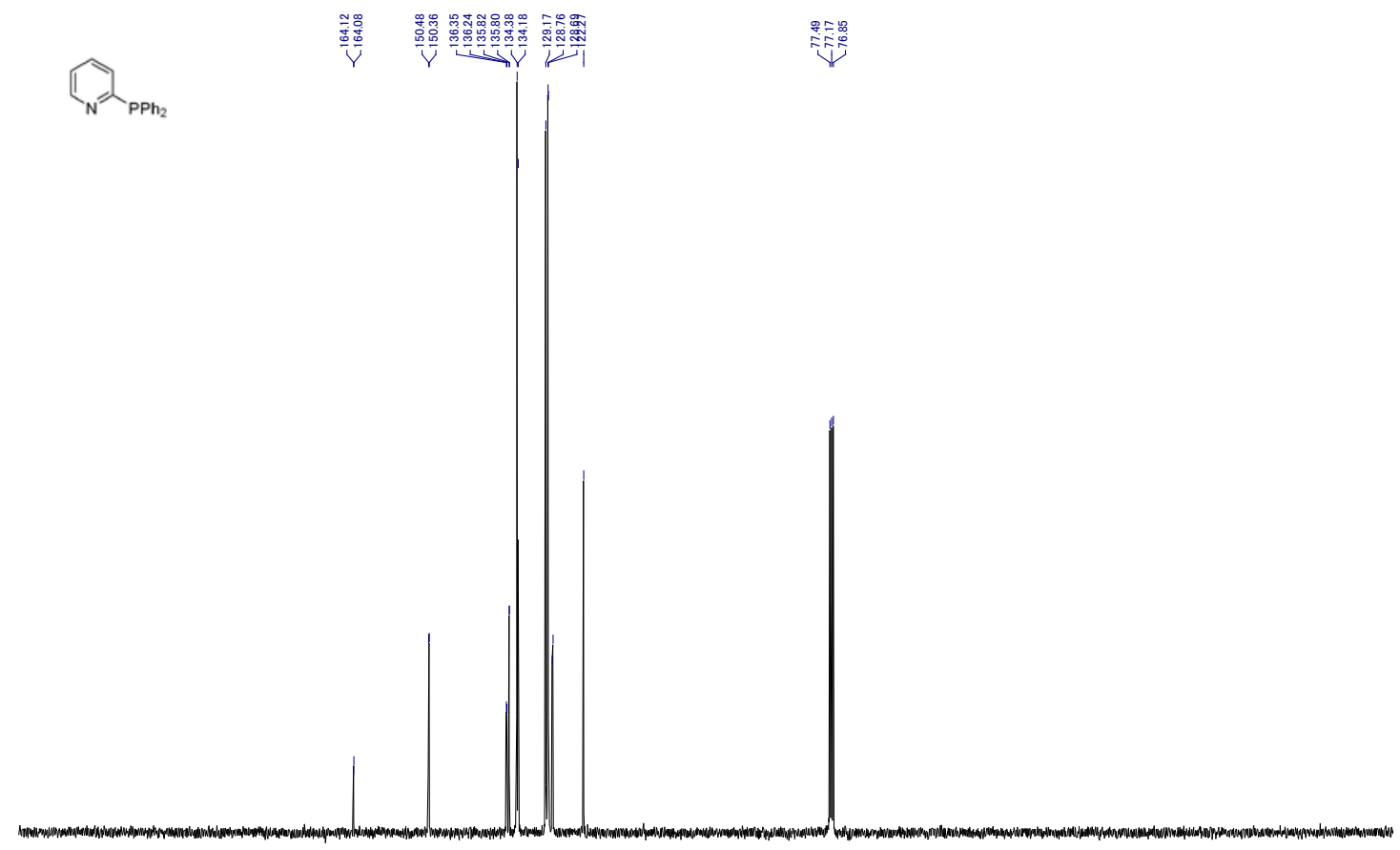

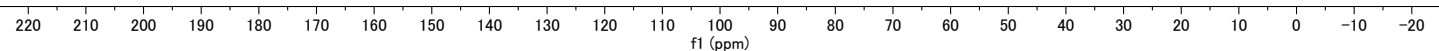


Figure S104: ${ }^{31} \mathrm{P}$ NMR (162 MHz, Chloroform-d) for 2-chloro(6-diphenylphosphino)pyridine (2n).<smiles>C[C@H]1CCC[C@H]1C</smiles>

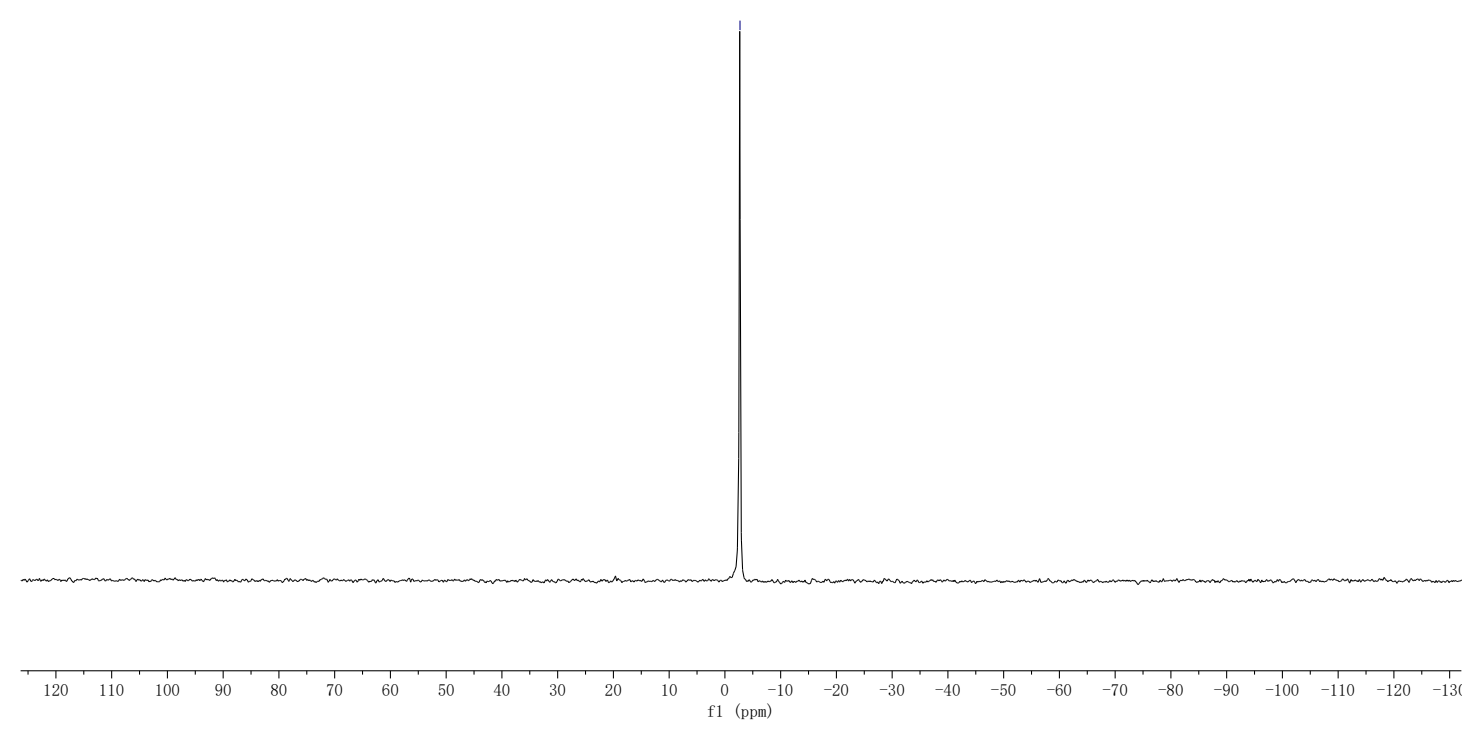

Figure S105: ${ }^{1} \mathrm{H}$ NMR (400 MHz, Chloroform- $d$ ) for 2-chloro(6-diphenylphosphino)pyridine (2n).

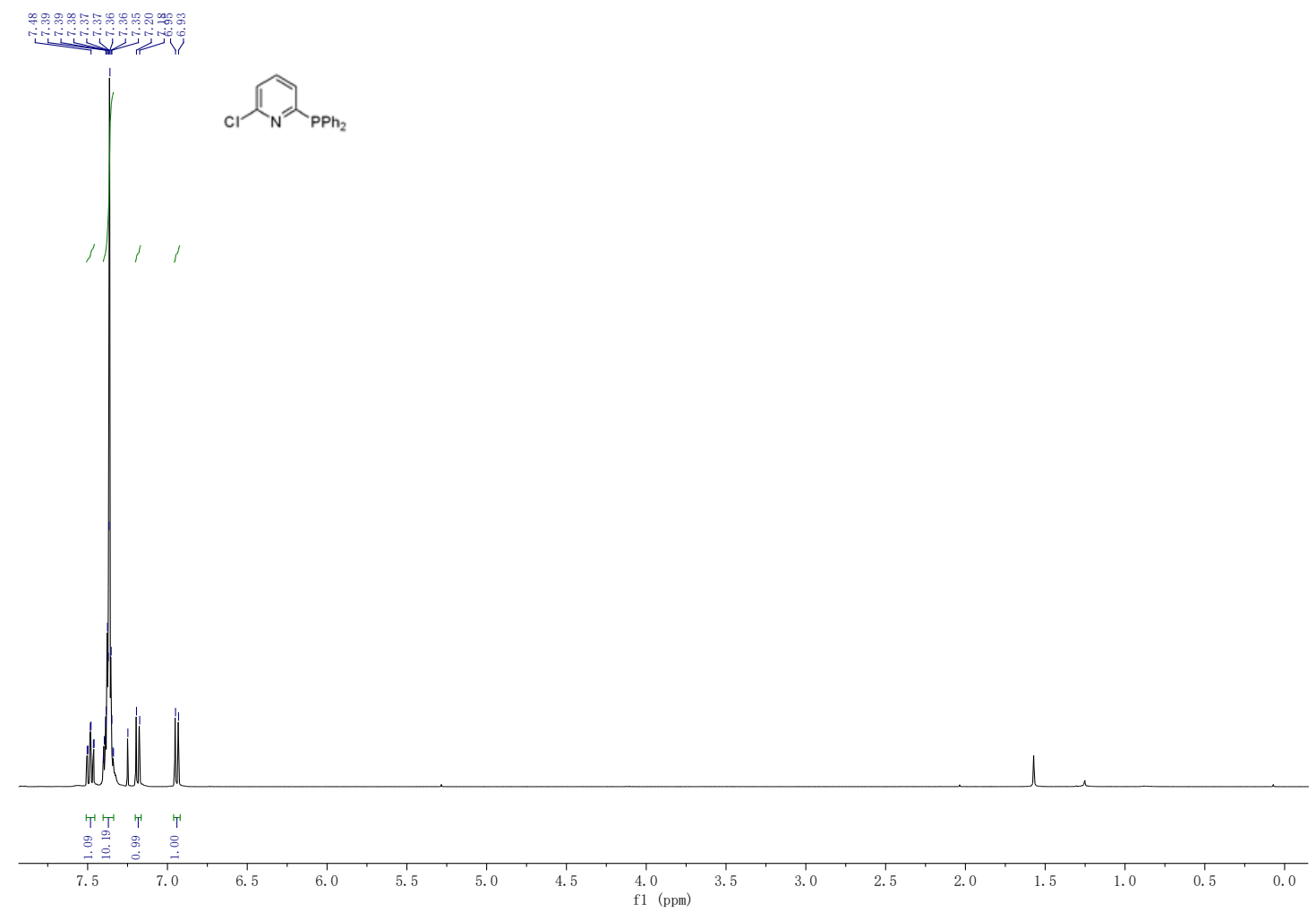


Figure S106: ${ }^{13} \mathrm{C}$ NMR (101 MHz, Chloroform- $d$ ) for 2-chloro(6-diphenylphosphino)pyridine $(2 n)$.
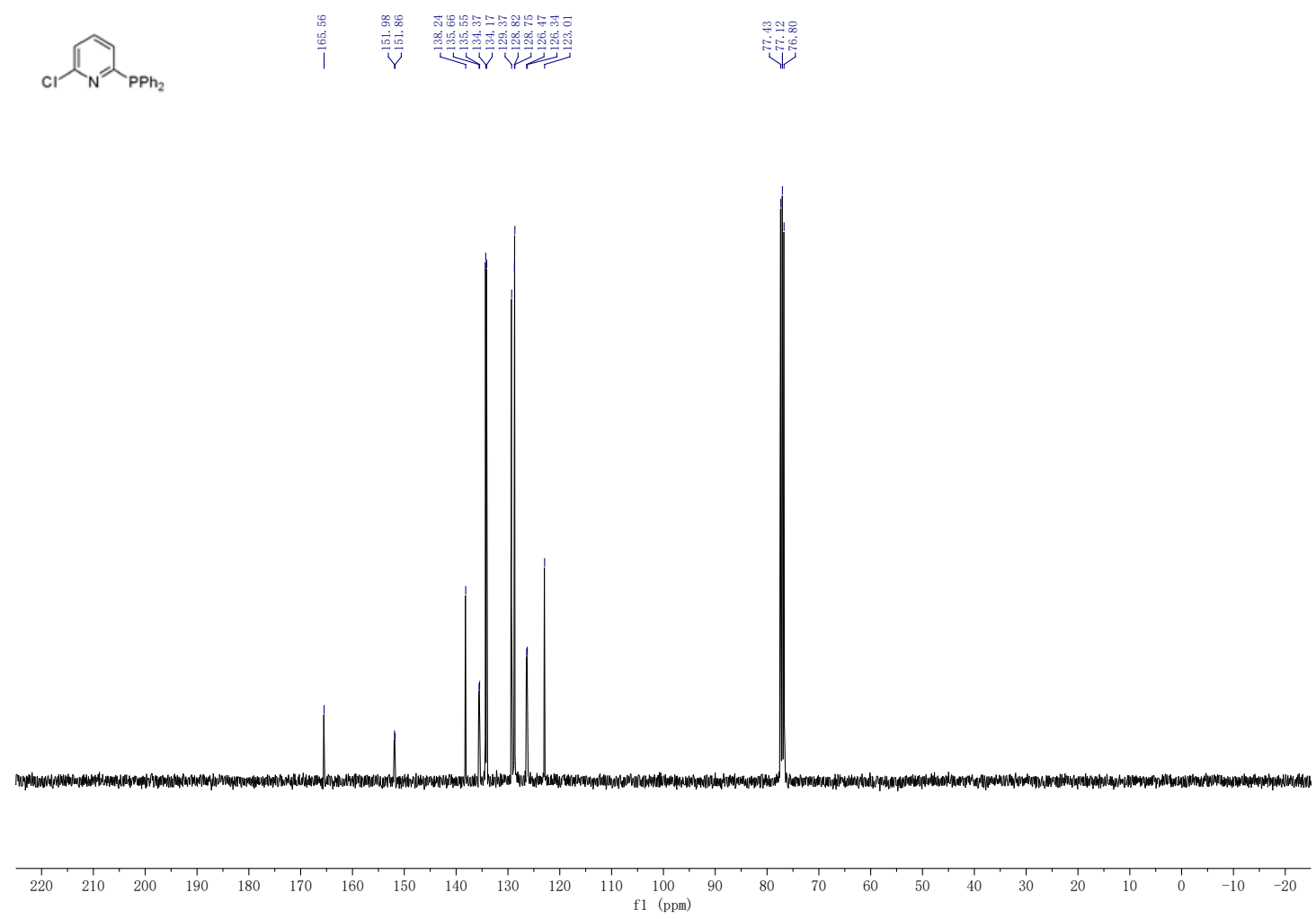

Figure S107: ${ }^{31} \mathrm{P}$ NMR (162 MHz, Chloroform- $d$ ) for (2,6-bis-diphenylphosphino)pyridine (2o).
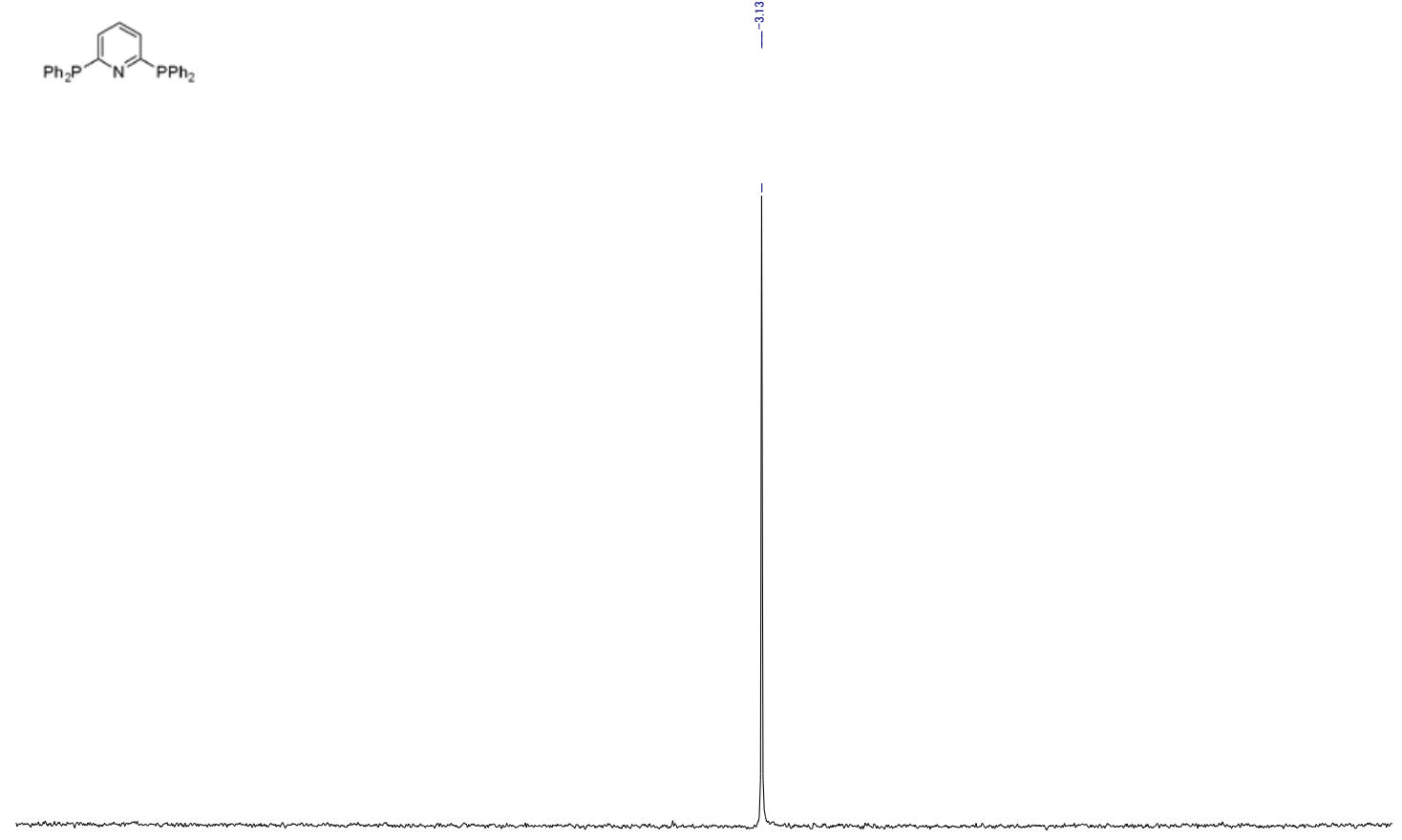

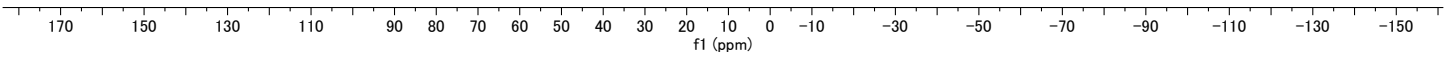


Figure S108: ${ }^{1} \mathrm{H}$ NMR (400 MHz, Chloroform-d) for (2,6-bis-diphenylphosphino)pyridine (2o).

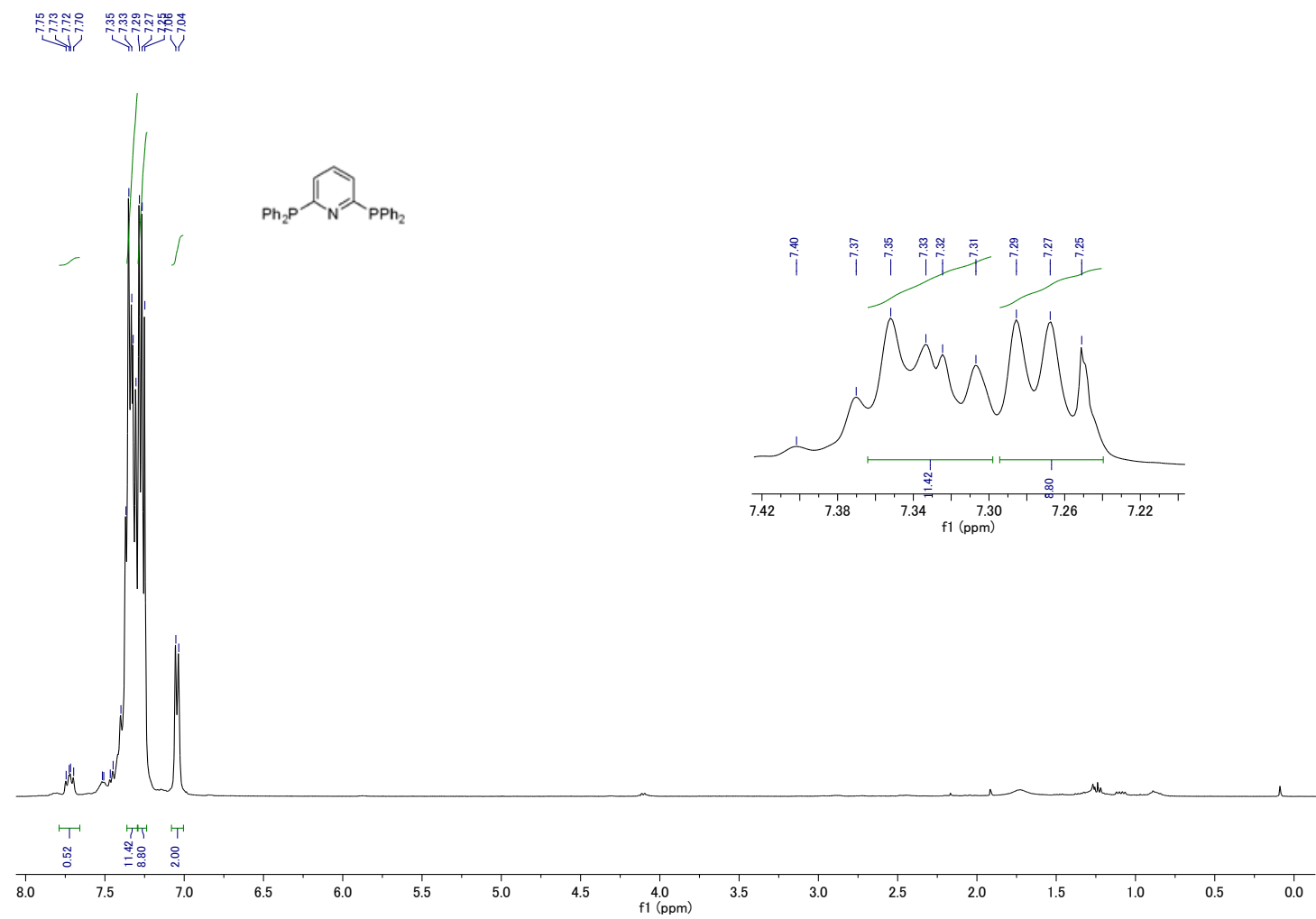

Figure S109: ${ }^{13} \mathrm{C}$ NMR (101 MHz, Chloroform-d) for (2,6-bis-diphenylphosphino)pyridine (2o).

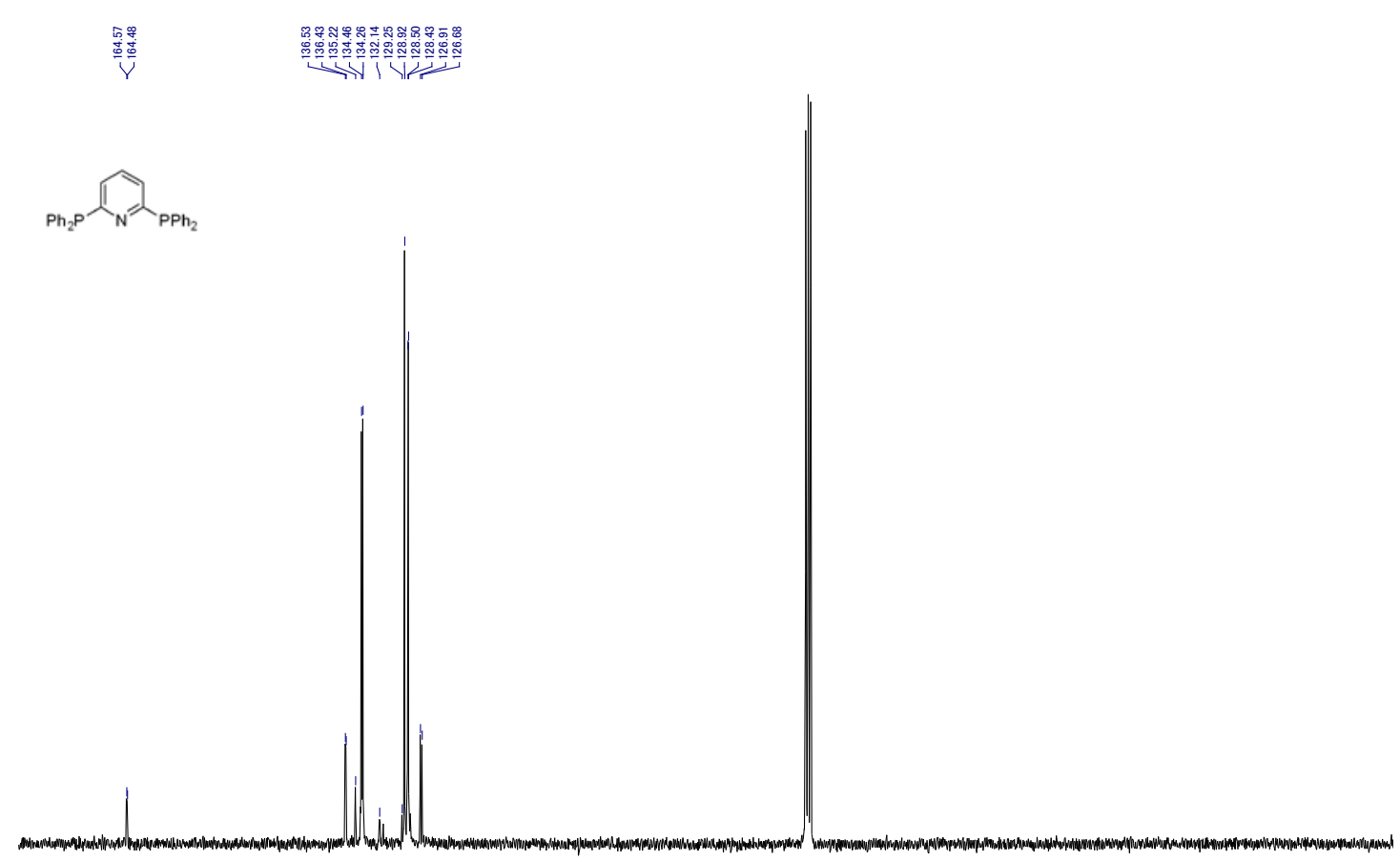


Figure S110: ${ }^{31}$ P NMR (162 MHz, Chloroform- $d$ ) for diphenyl(2-thienyl)phosphine (2p).<smiles>C[As]1CCCC1</smiles>

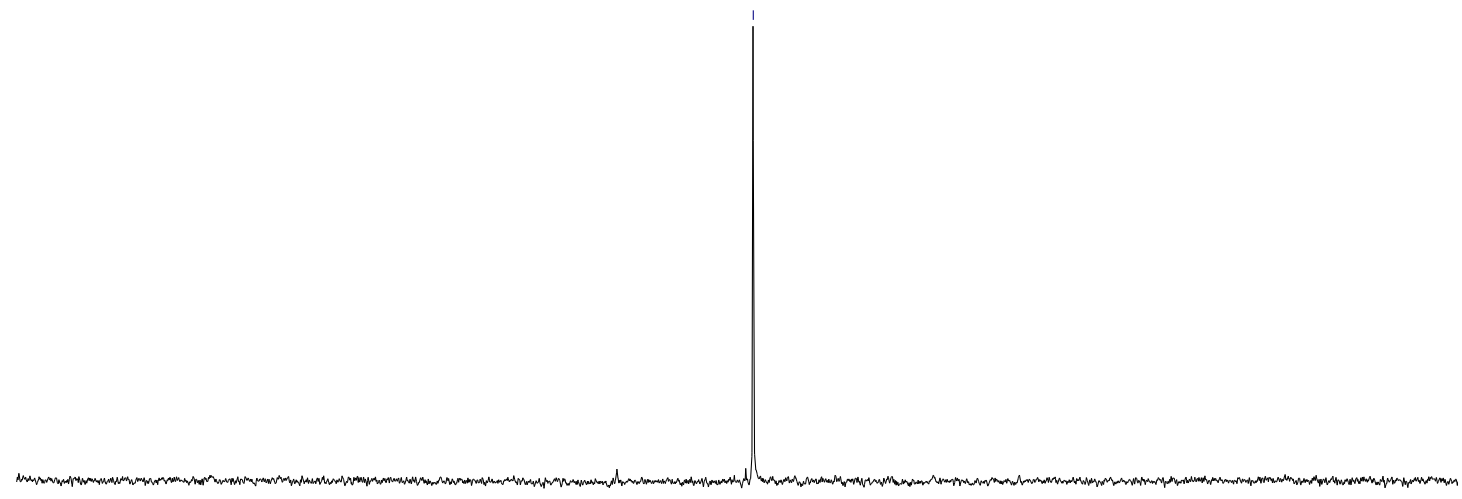

Figure S111: ${ }^{1} \mathrm{H}$ NMR (400 MHz, Chloroform-d) for diphenyl(2-thienyl)phosphine (2p).

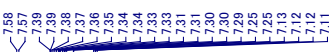

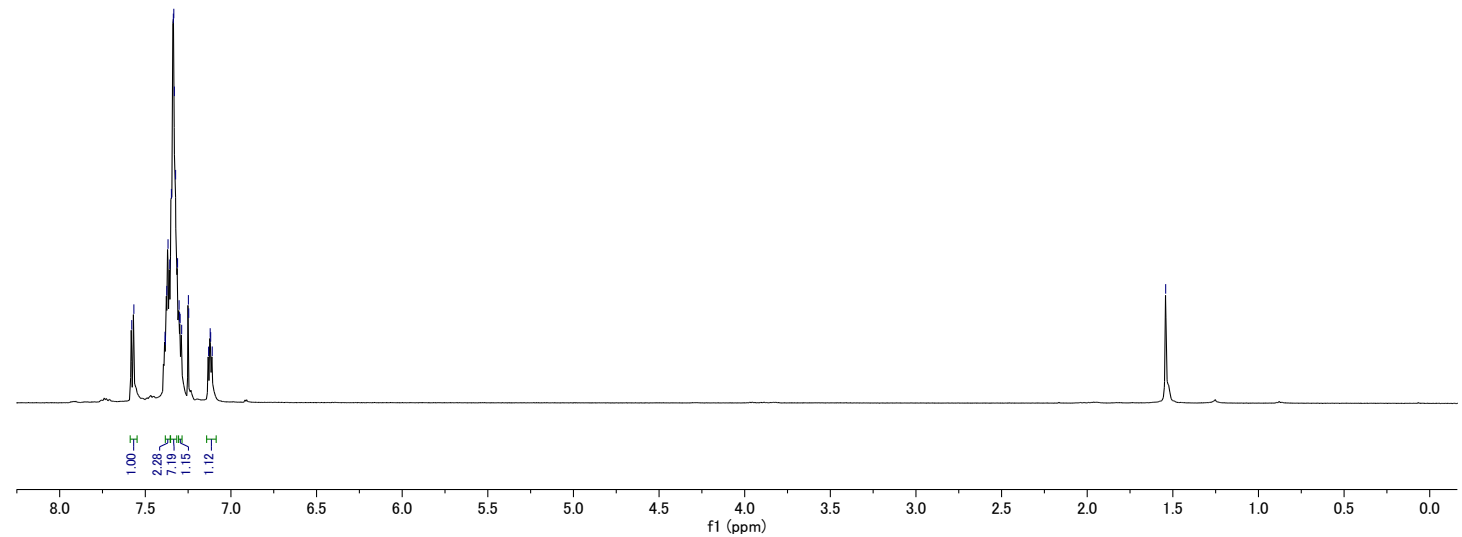


Figure S112: ${ }^{13} \mathrm{C}$ NMR (101 MHz, Chloroform- $d$ ) for diphenyl(2-thienyl)phosphine (2p).
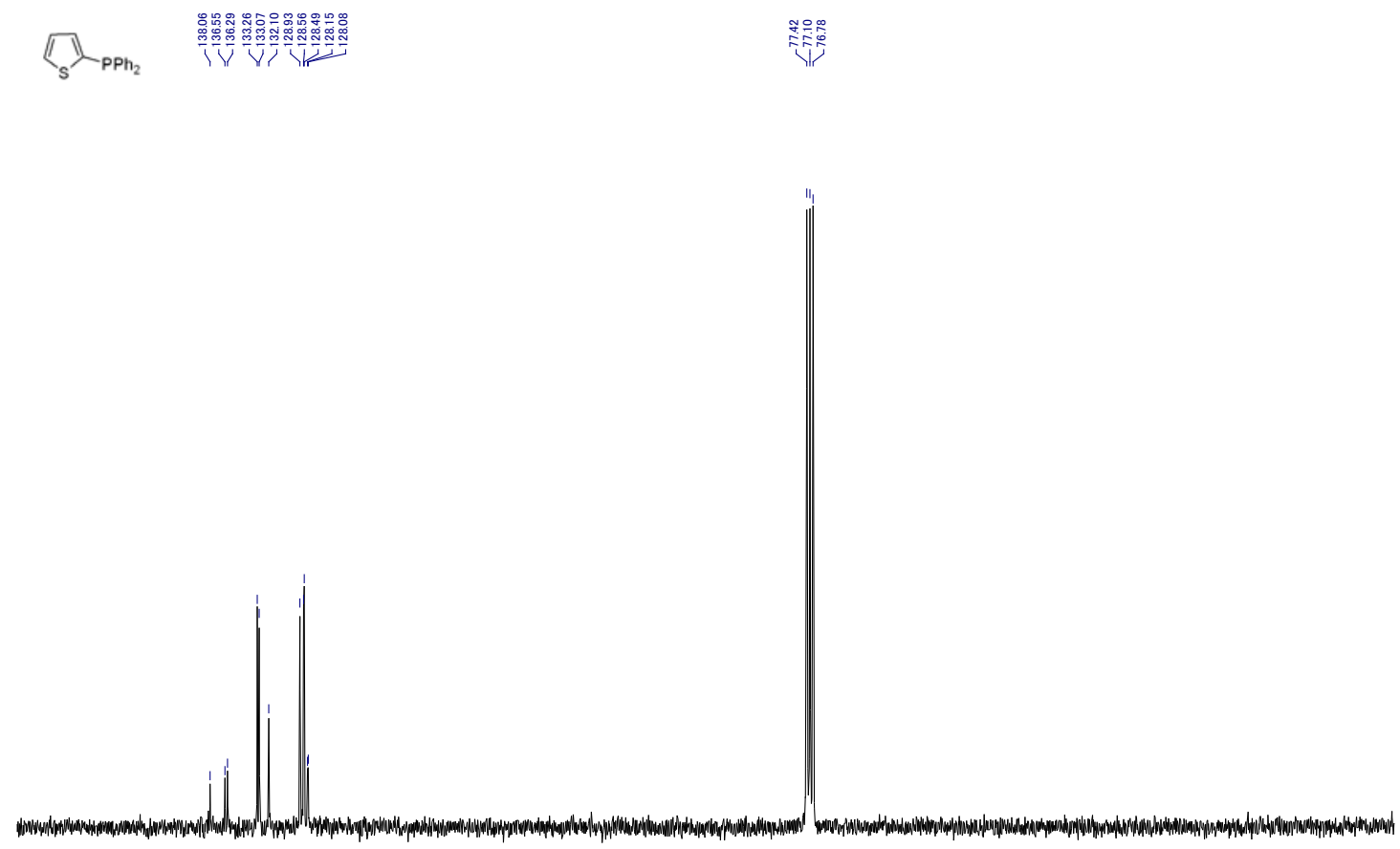

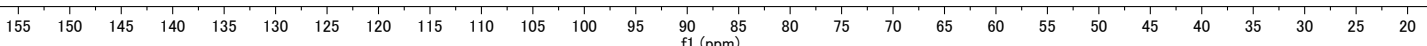

Figure S113: ${ }^{31}$ P NMR (162 MHz, Chloroform-d) for (2,5-bis-diphenylphosphino)thiophene (2q). $\mathrm{Ph}_{2} \mathrm{P}-\mathrm{ln}_{\mathrm{SPh}}$

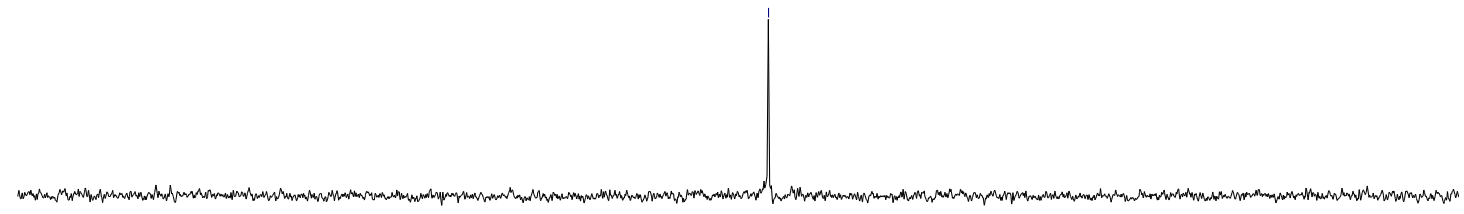

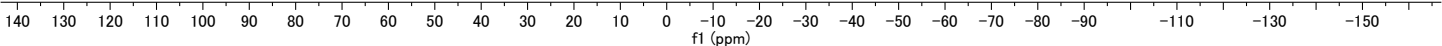


Figure S114: ${ }^{1} \mathrm{H}$ NMR (400 MHz, Chloroform- $d$ ) for (2,5-bis-diphenylphosphino)thiophene (2q).

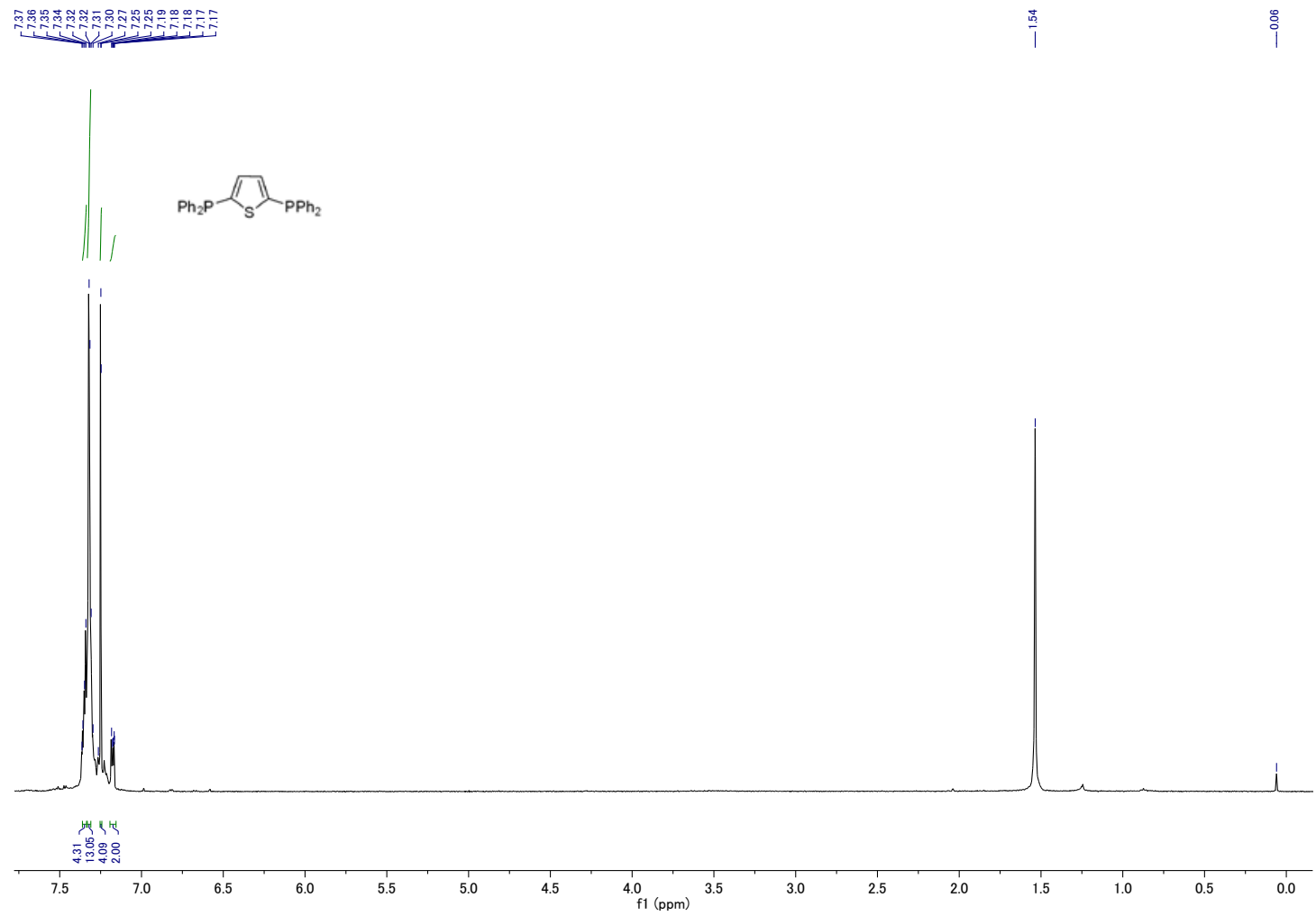

Figure S115: ${ }^{13} \mathrm{C}$ NMR (101 MHz, Chloroform- $d$ ) for (2,5-bis-diphenylphosphino)thiophene (2q).

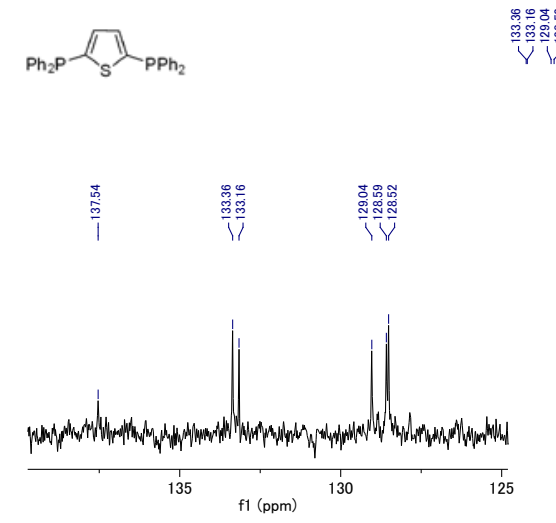

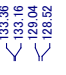

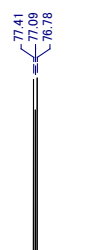

$\begin{array}{llllllllllllllllllllllllllllllll}220 & 210 & 200 & 190 & 180 & 170 & 160 & 150 & 140 & 130 & 120 & 110 & \begin{array}{c}100 \\ \mathrm{f} 1\end{array}(\mathrm{ppm}) & 90 & 80 & 70 & 60 & 50 & 40 & 30 & 20 & 10 & 0 & -10 & -20\end{array}$ 
Figure S116: ${ }^{31} \mathrm{P}$ NMR (162 MHz, Chloroform-d) for (2-chlorophenyl)diphenylphosphine (2r).
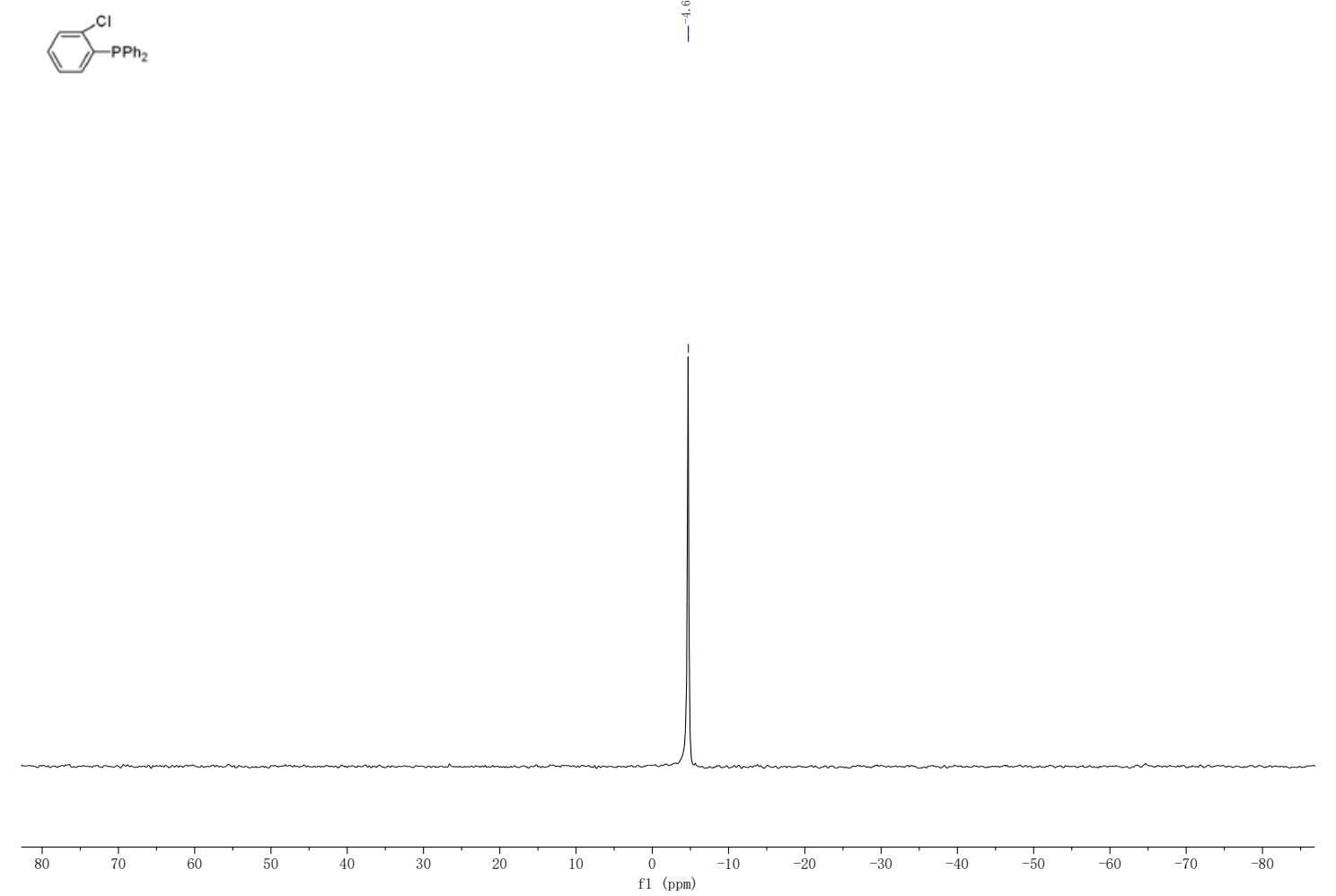

Figure S117: ${ }^{1} \mathrm{H}$ NMR (400 MHz, Chloroform- $d$ ) for (2-chlorophenyl)diphenylphosphine (2r).

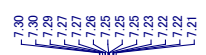
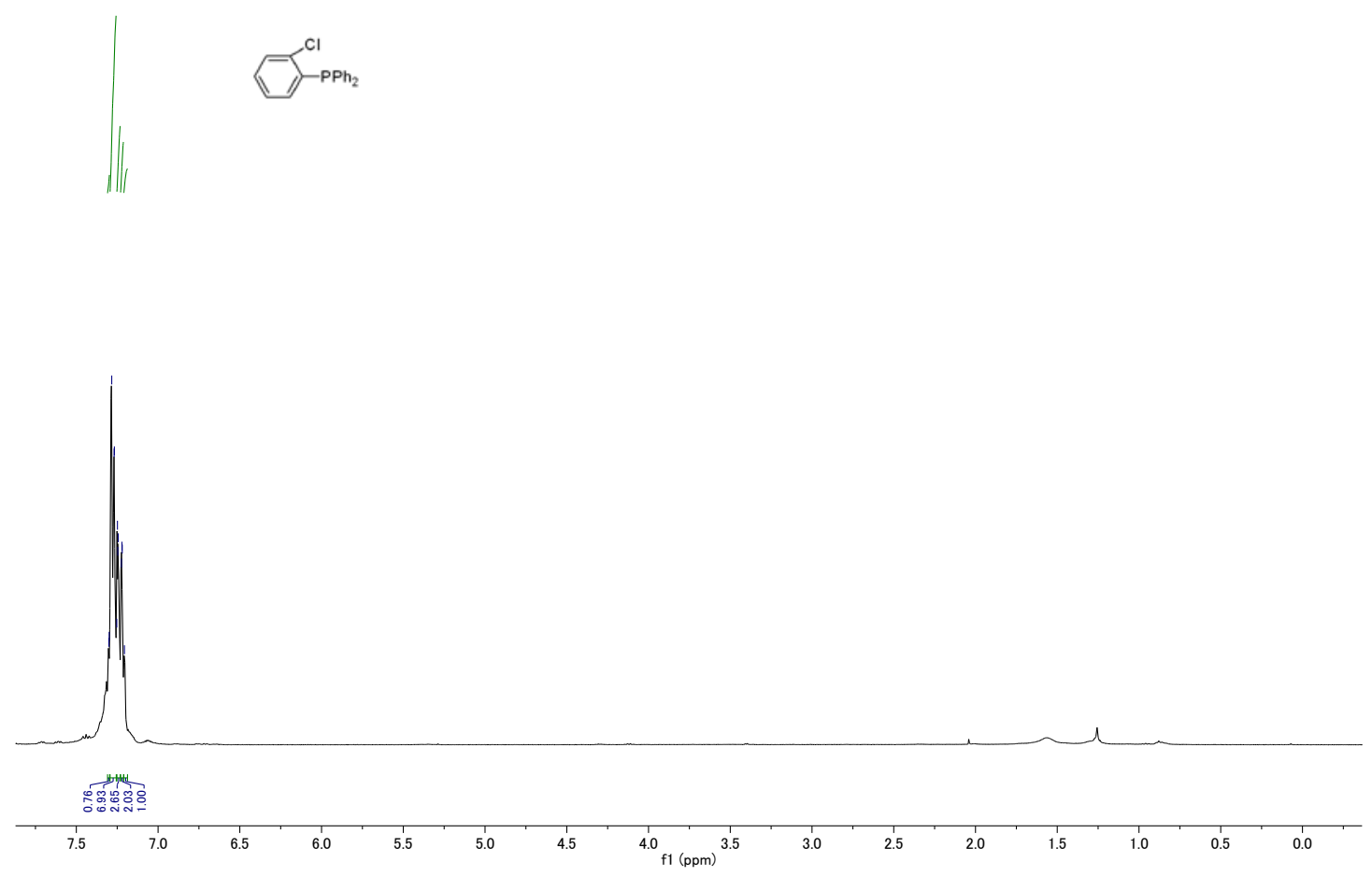
Figure S118: ${ }^{13} \mathrm{C}$ NMR (101 MHz, Chloroform- $d$ ) for (2-chlorophenyl)diphenylphosphine (2r).
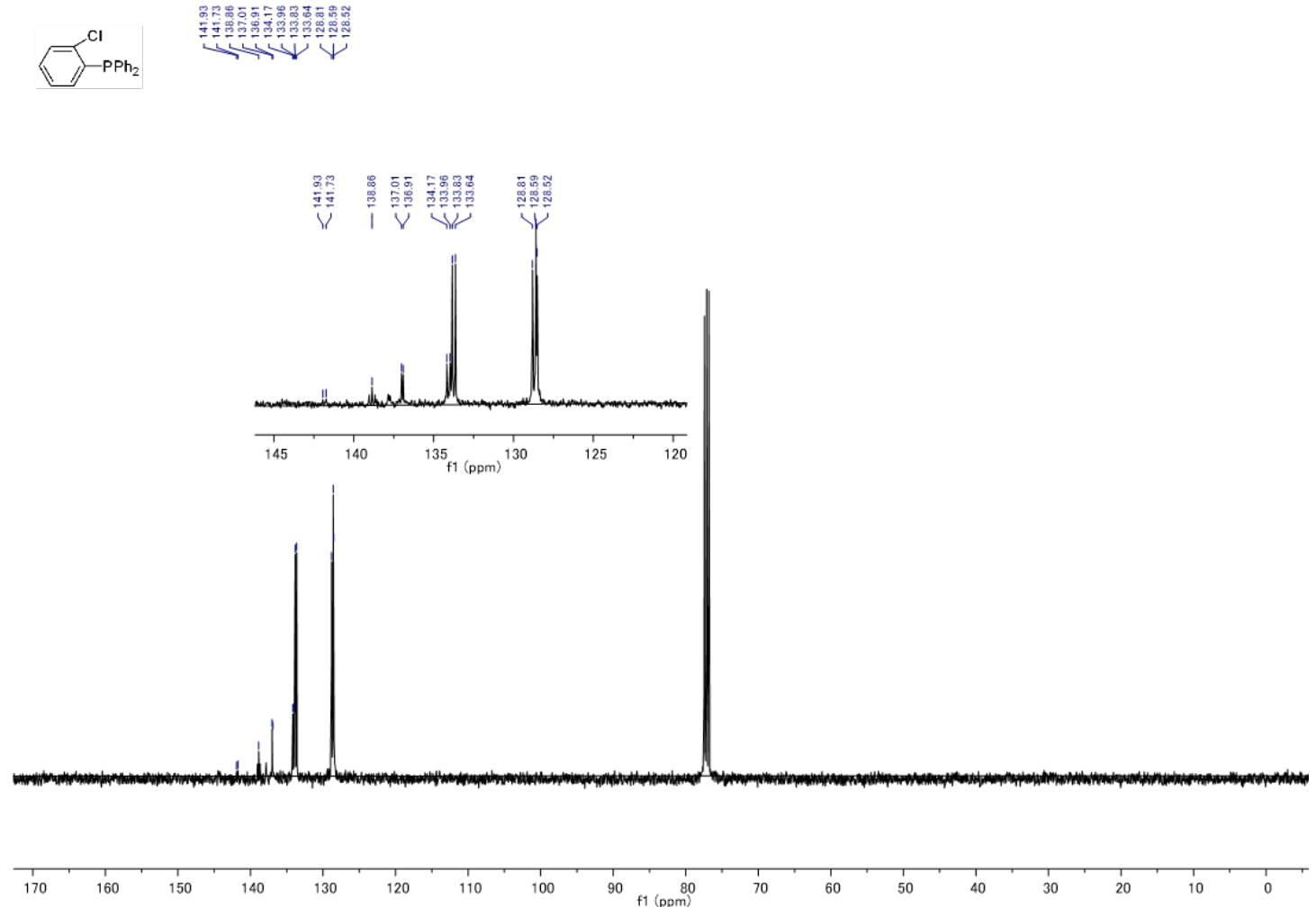

Figure S119: ${ }^{31} \mathrm{P}$ NMR (162 MHz, Chloroform- $d$ ) for (3-chlorophenyl)diphenylphosphine (2s).
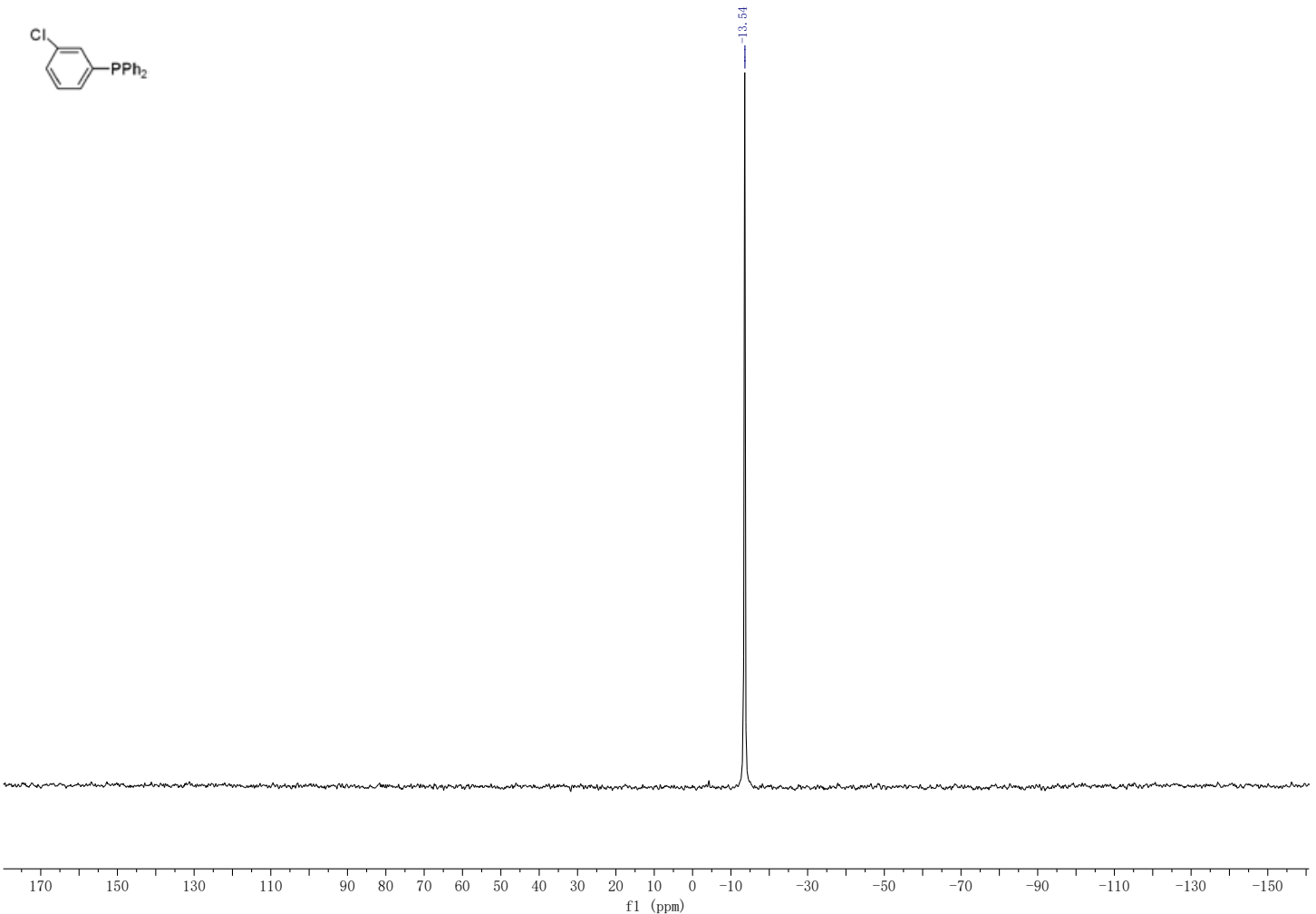
Figure S120: ${ }^{1} \mathrm{H}$ NMR (400 MHz, Chloroform-d) for (3-chlorophenyl)diphenylphosphine (2s).

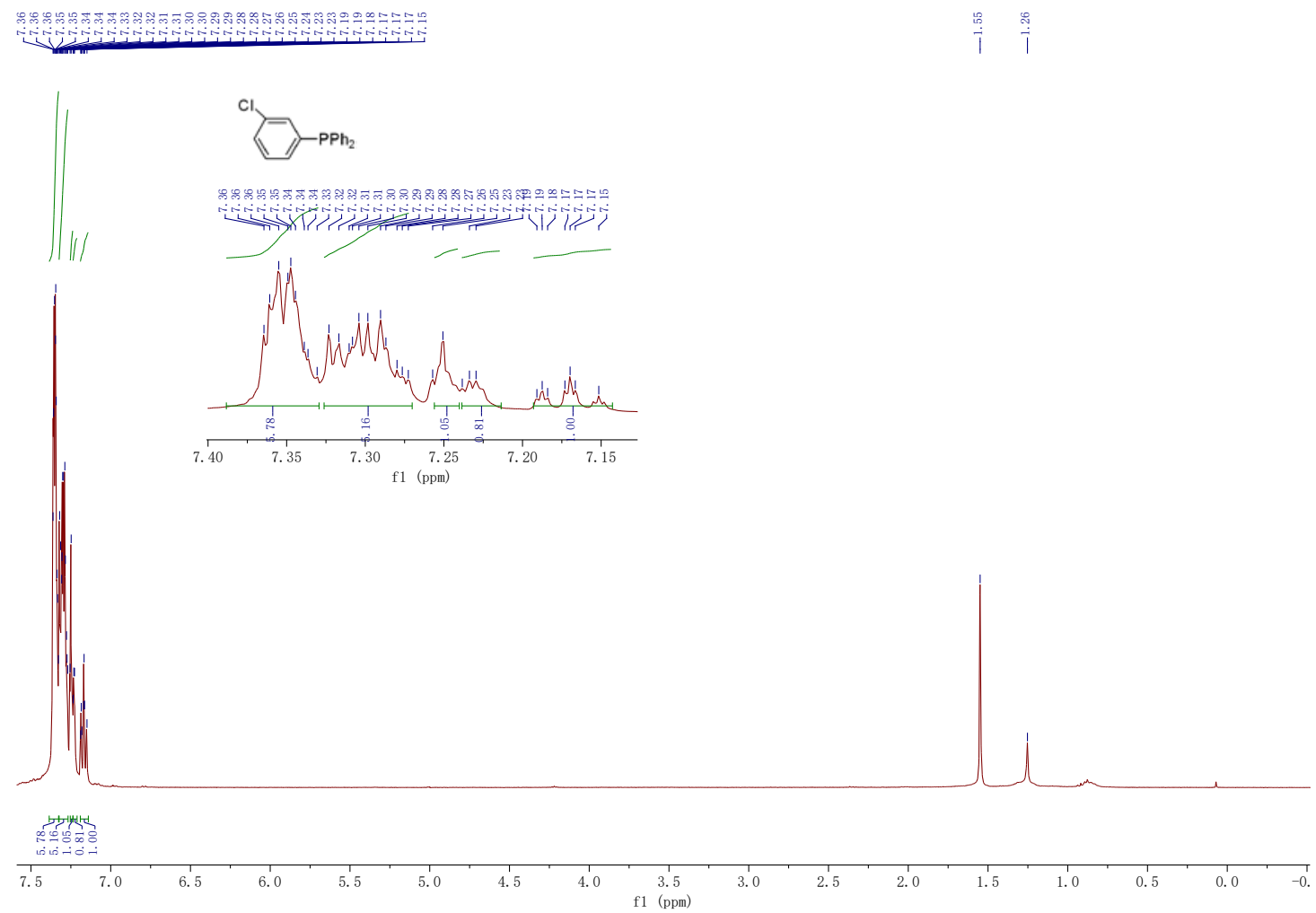

Figure S121: ${ }^{13} \mathrm{C}$ NMR (101 MHz, Chloroform-d) for (3-chlorophenyl)diphenylphosphine (2s).

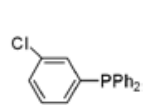

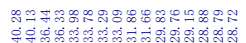

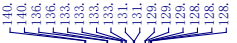

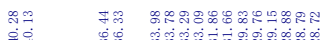

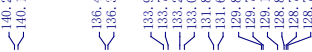
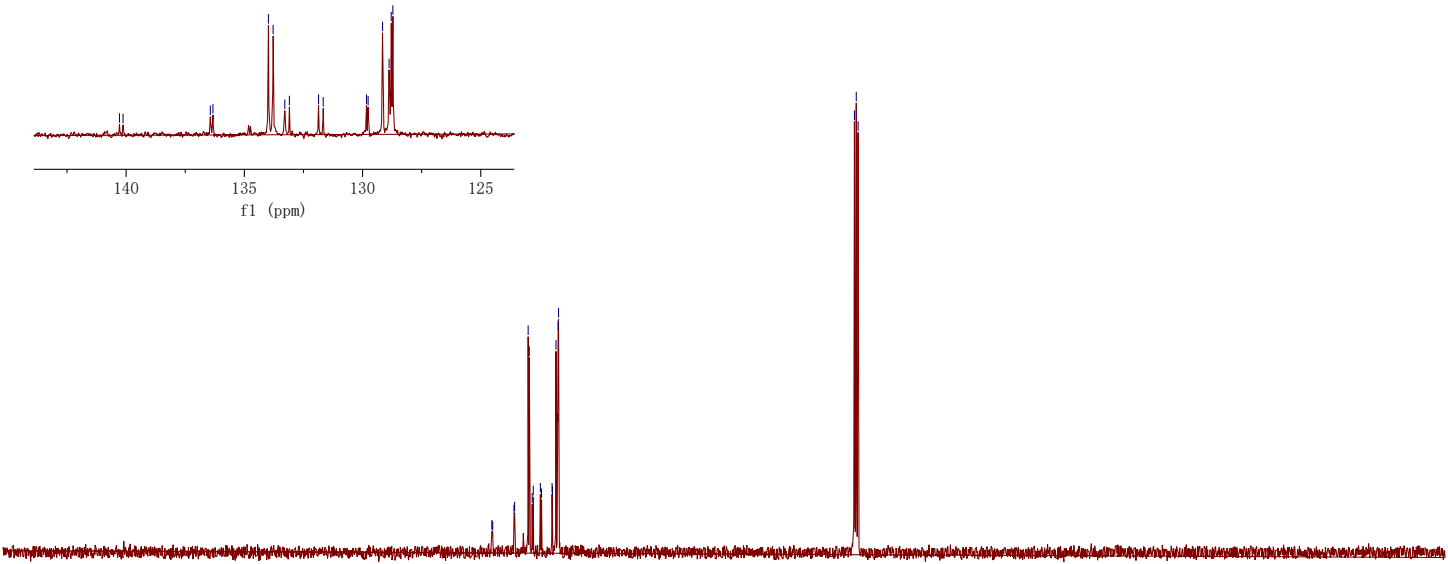

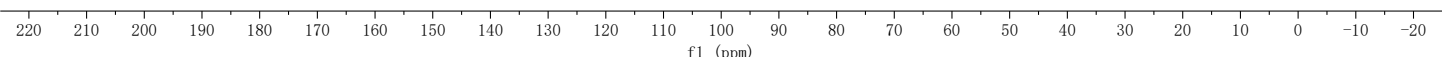


Figure S122: ${ }^{31} \mathrm{P}$ NMR (162 MHz, Chloroform- $d$ ) for (3,5-dichlorophenyl)diphenylphosphine (2t).
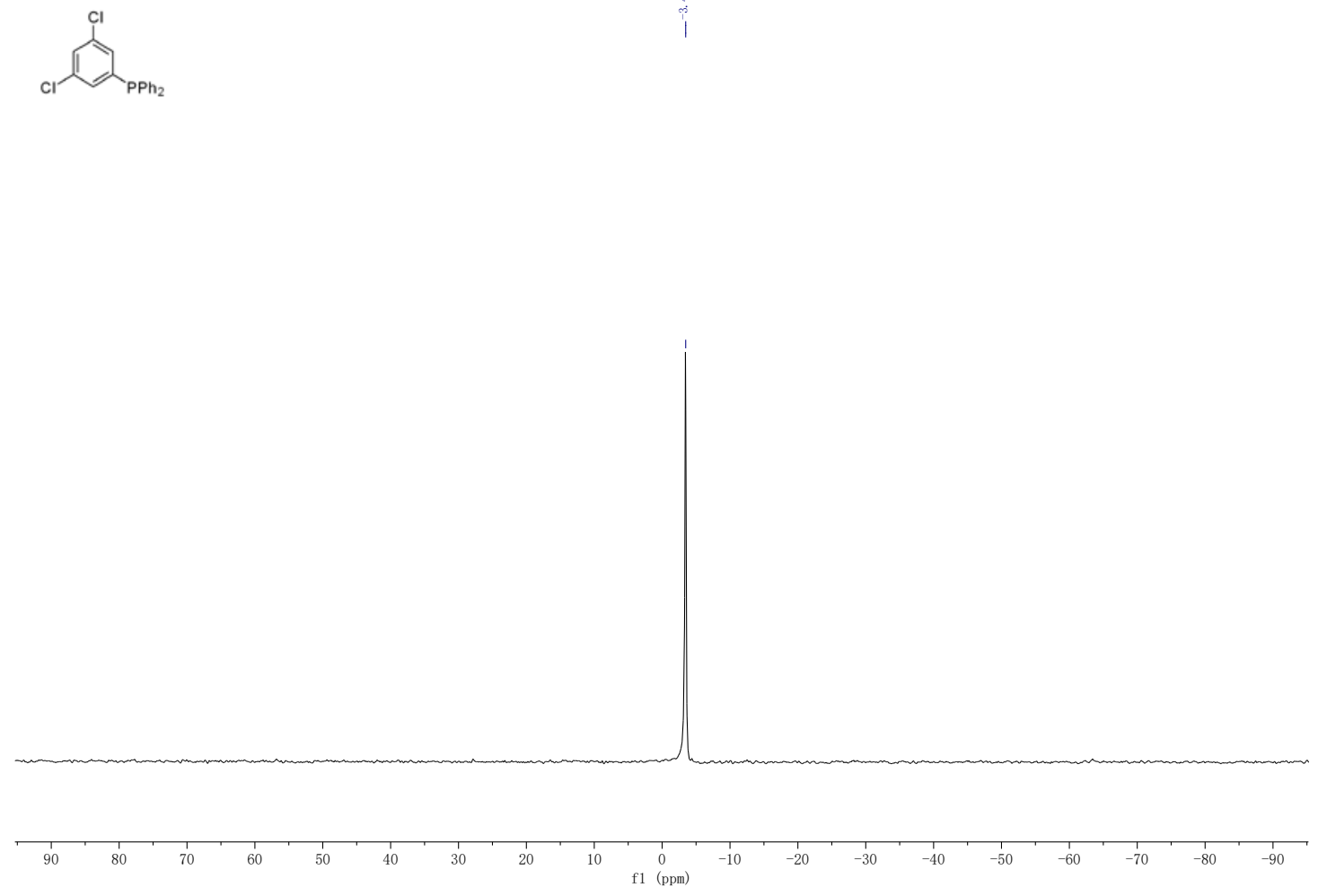

Figure S123: ${ }^{1} \mathrm{H}$ NMR (400 MHz, Chloroform- $d$ ) for (3,5-dichlorophenyl)diphenylphosphine (2t).

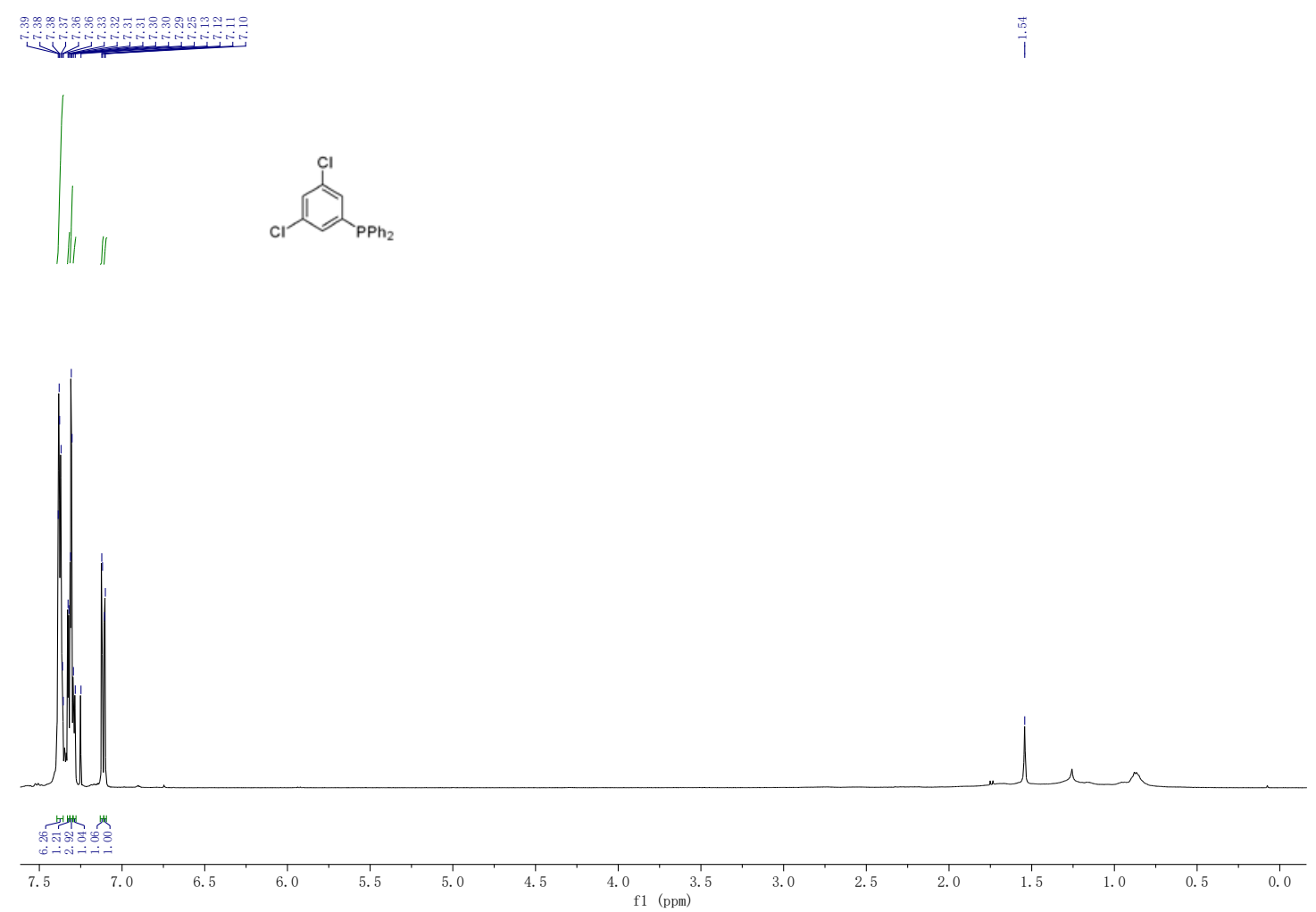


Figure S124: ${ }^{13} \mathrm{C}$ NMR (101 MHz, Chloroform- $d$ ) for (3,5-dichlorophenyl)diphenylphosphine (2t).

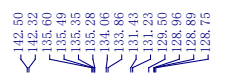
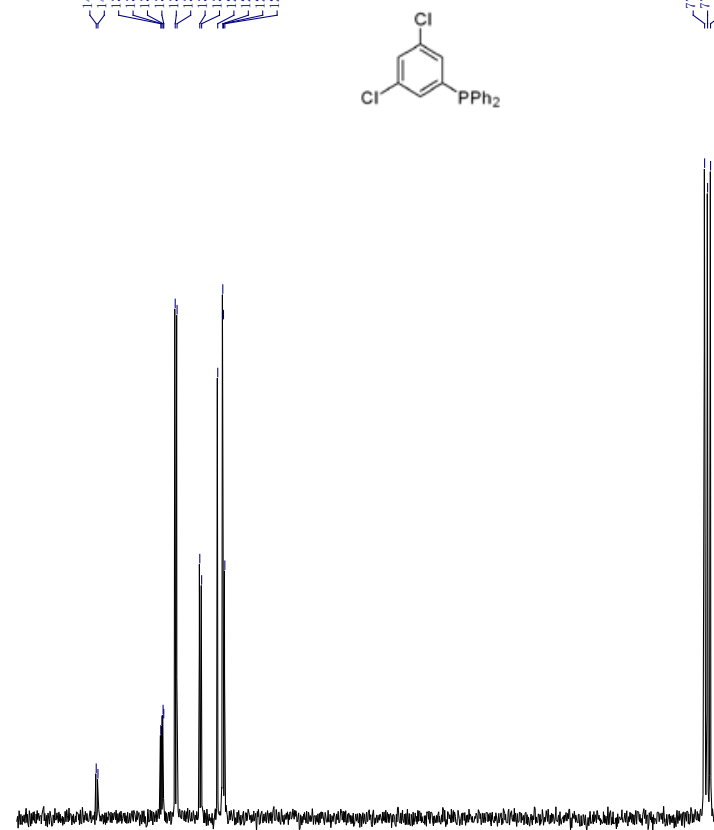

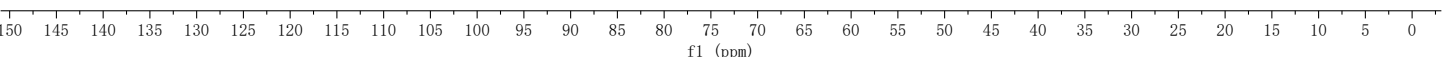

Figure S125: ${ }^{31} \mathrm{P}$ NMR (162 MHz, Chloroform- $d$ ) for (1,4-bis-diphenylphosphino)benzene (2u).<smiles>c1ccc(-c2ccccc2)cc1</smiles>

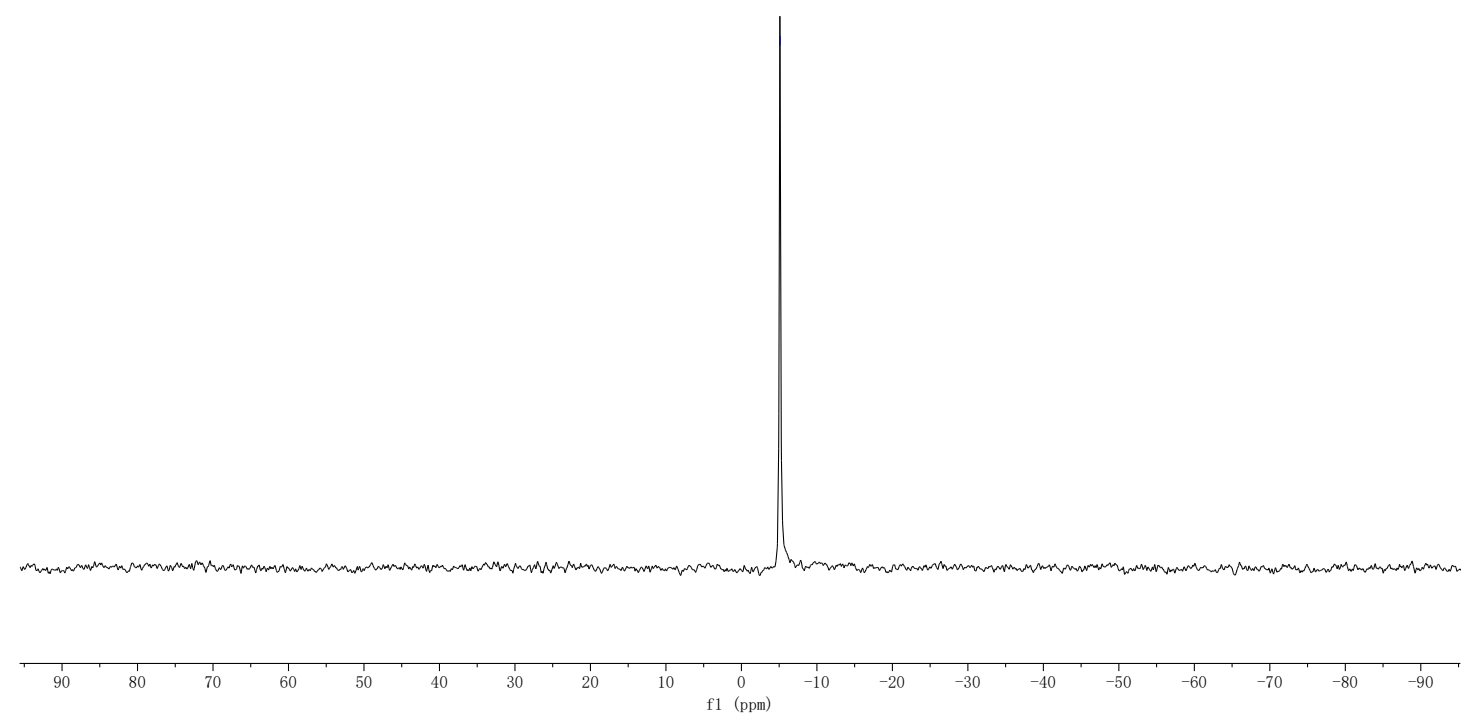


Figure S126: ${ }^{1} \mathrm{H}$ NMR (400 MHz, Chloroform-d) for (1,4-bis-diphenylphosphino)benzene (2u).

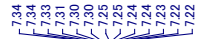
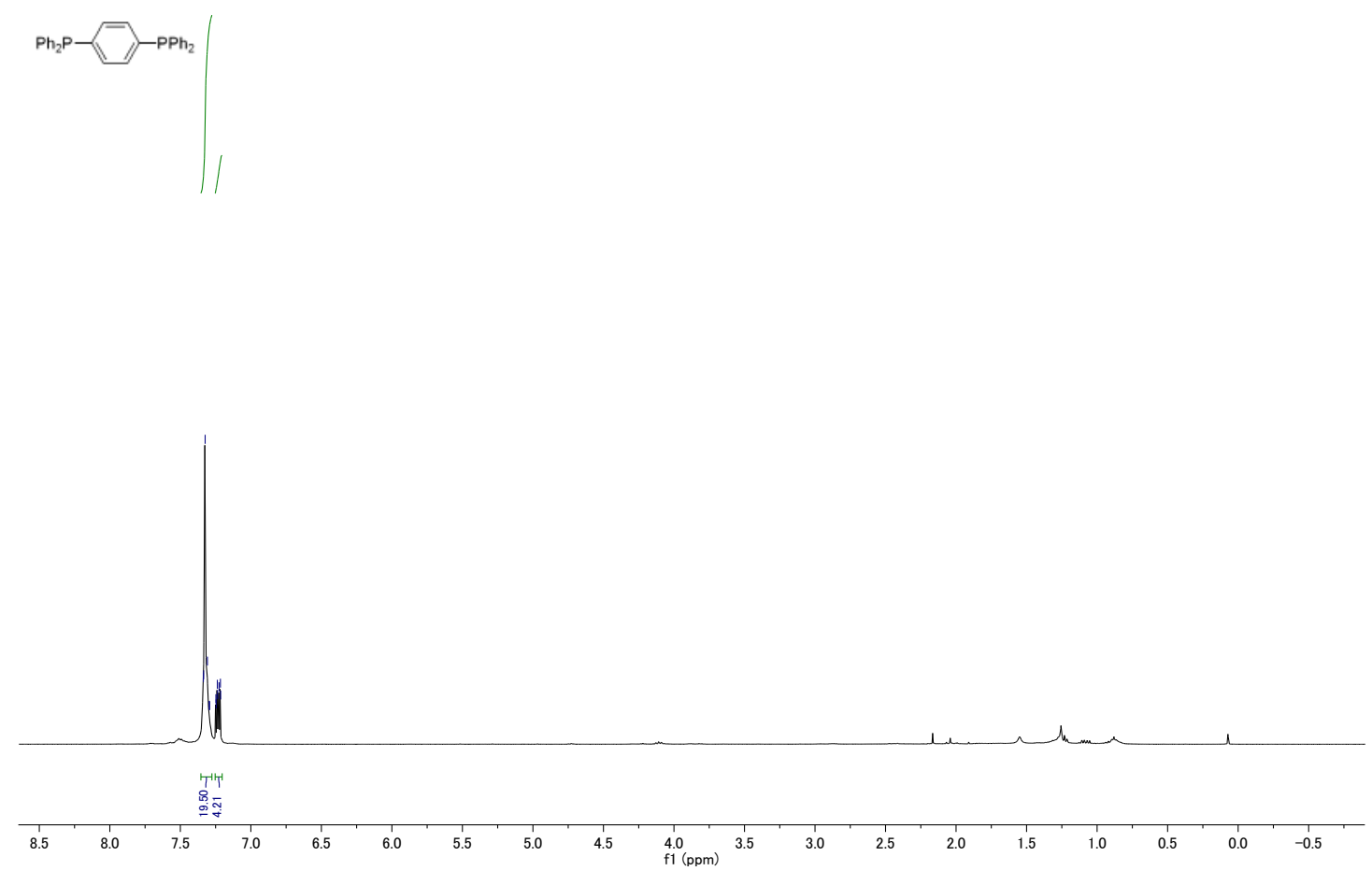

Figure S127: ${ }^{13} \mathrm{C}$ NMR (101 MHz, Chloroform-d) for (1,4-bis-diphenylphosphino)benzene (2u).

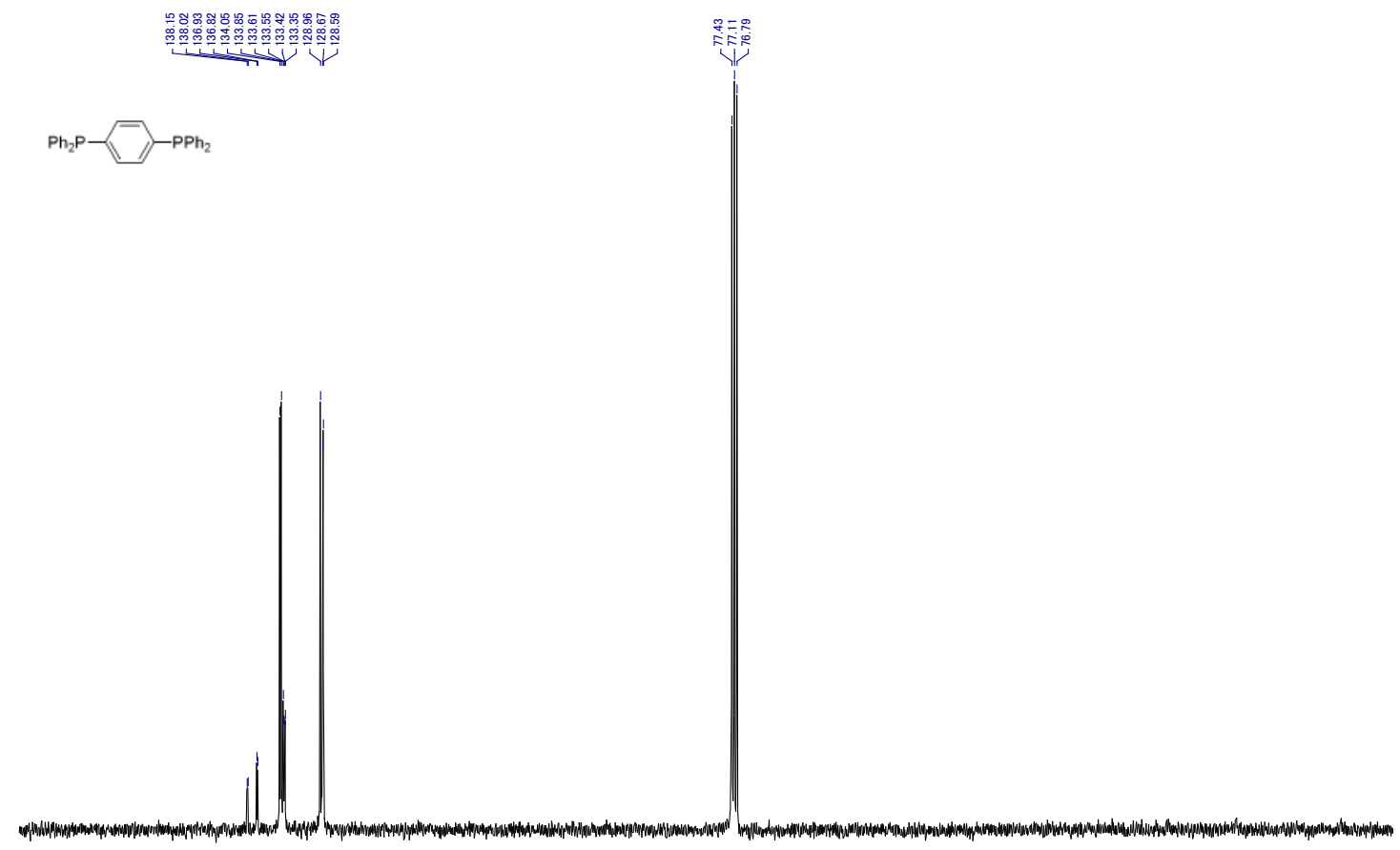

$160 \quad 150$

130

120 
Figure S128: ${ }^{31} \mathrm{P}$ NMR (162 MHz, Chloroform- $d$ ) for trans-1,2-bis-diphenylphosphinoethylene $(2 \mathbf{v})$.

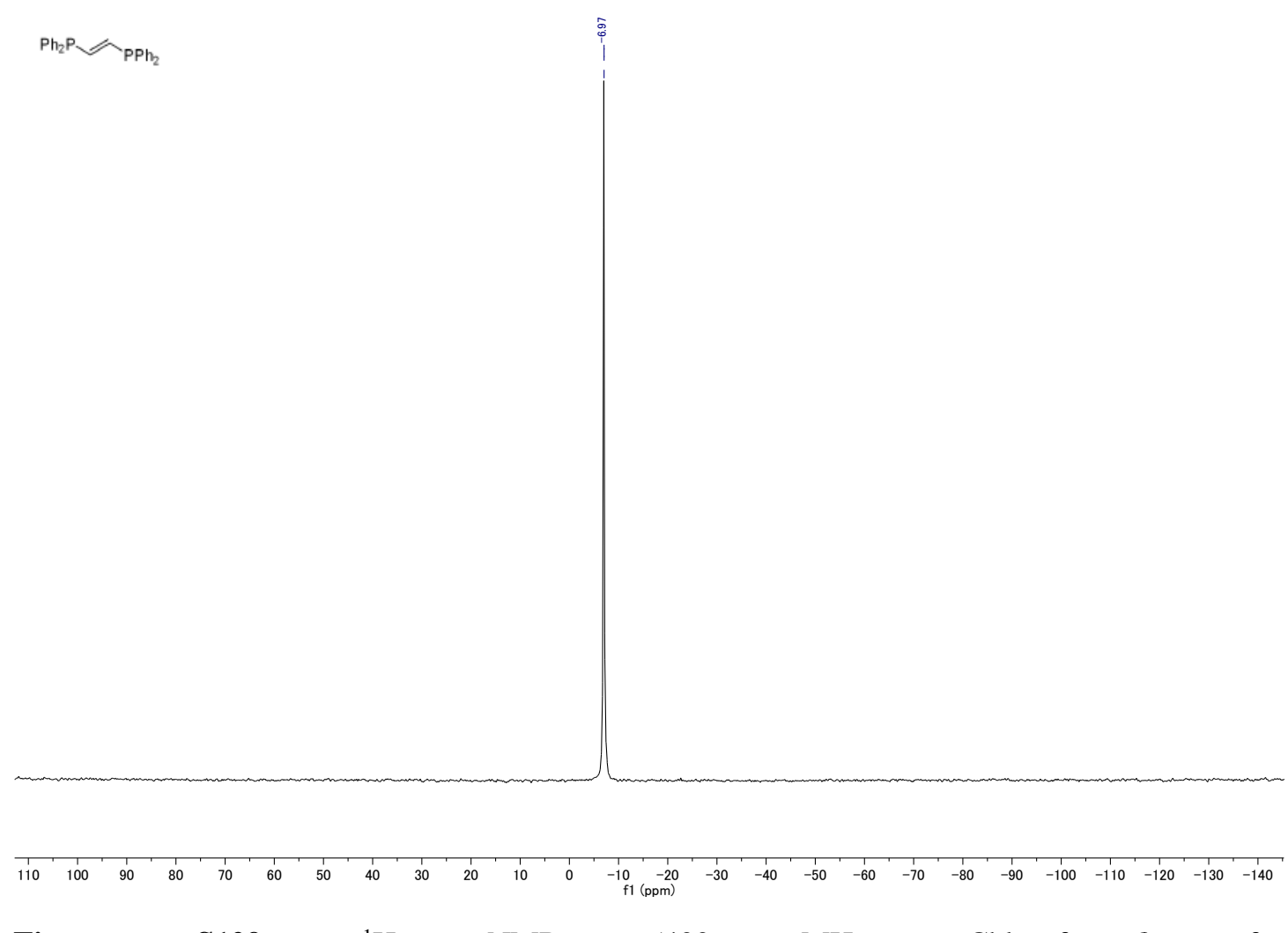

$\begin{array}{lllllll}\text { Figure } & \text { S129: } & { }^{1} \mathrm{H} & \mathrm{NMR} & (400 \quad \mathrm{MHz}, & \text { Chloroform- } d) & \text { for }\end{array}$ trans-1,2-bis-diphenylphosphinoethylene(2v).

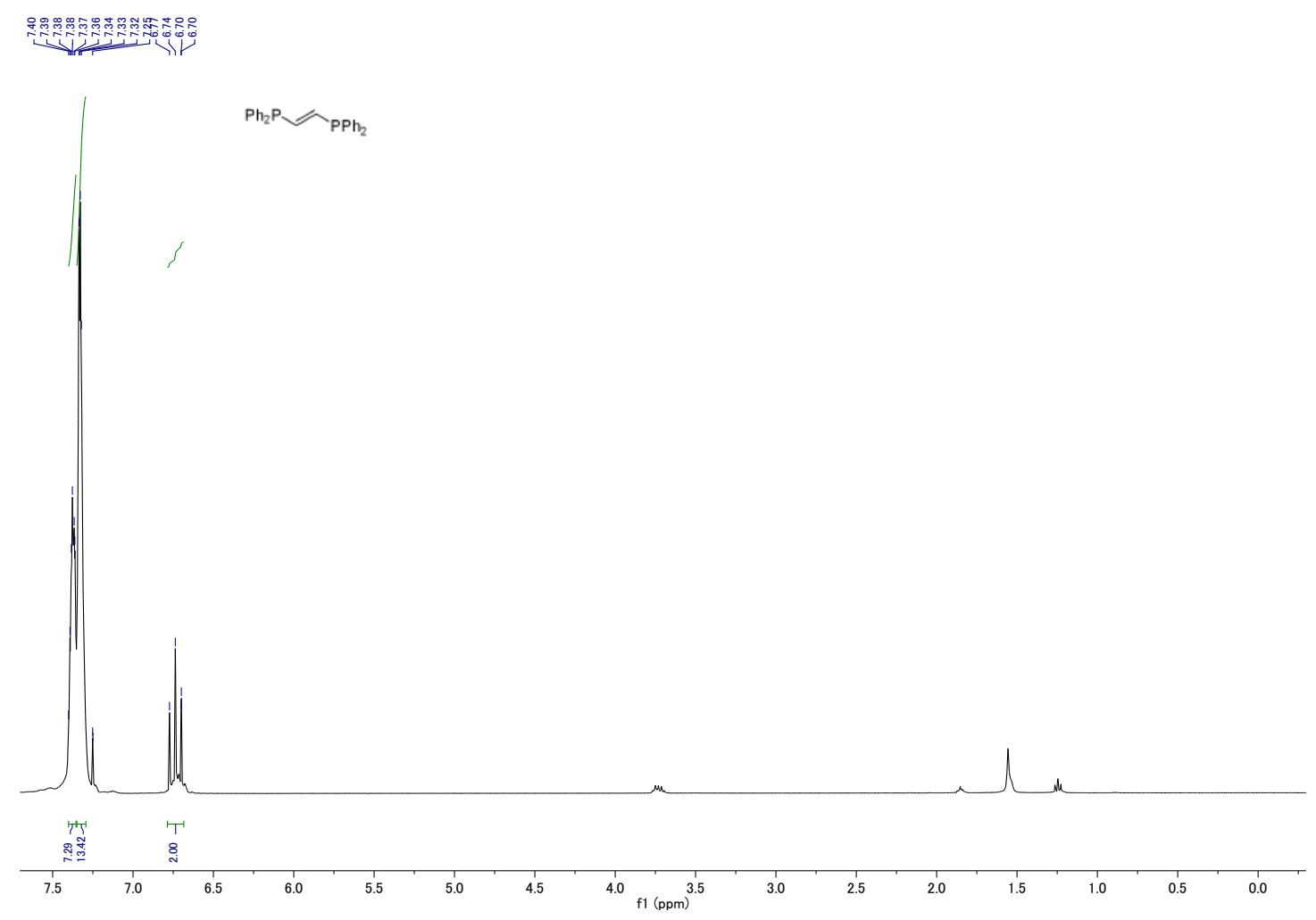


Figure S130: ${ }^{13} \mathrm{C}$ NMR (101 MHz, Chloroform- $d$ ) for trans-1,2-bis-diphenylphosphinoethylene $(2 \mathbf{v})$.
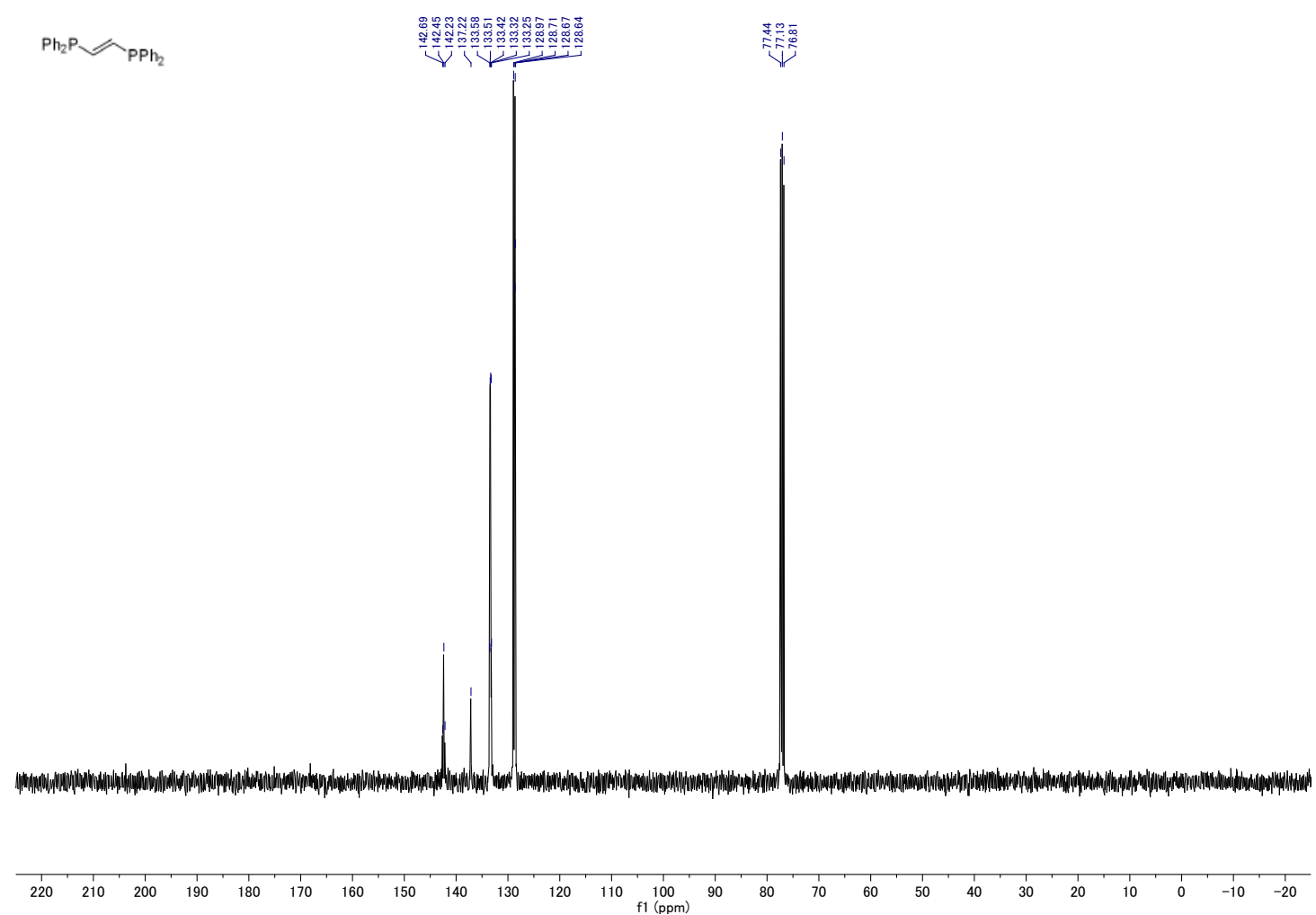

$\begin{array}{lllllll}\text { Figure } & \text { S131: } & { }^{31} \mathrm{P} & \mathrm{NMR} & (162 \quad \mathrm{MHz}, & \text { Chloroform- } d) & \text { for }\end{array}$ diphenyl(2,4,6-triisopropylbenzyl)phosphine (2w).
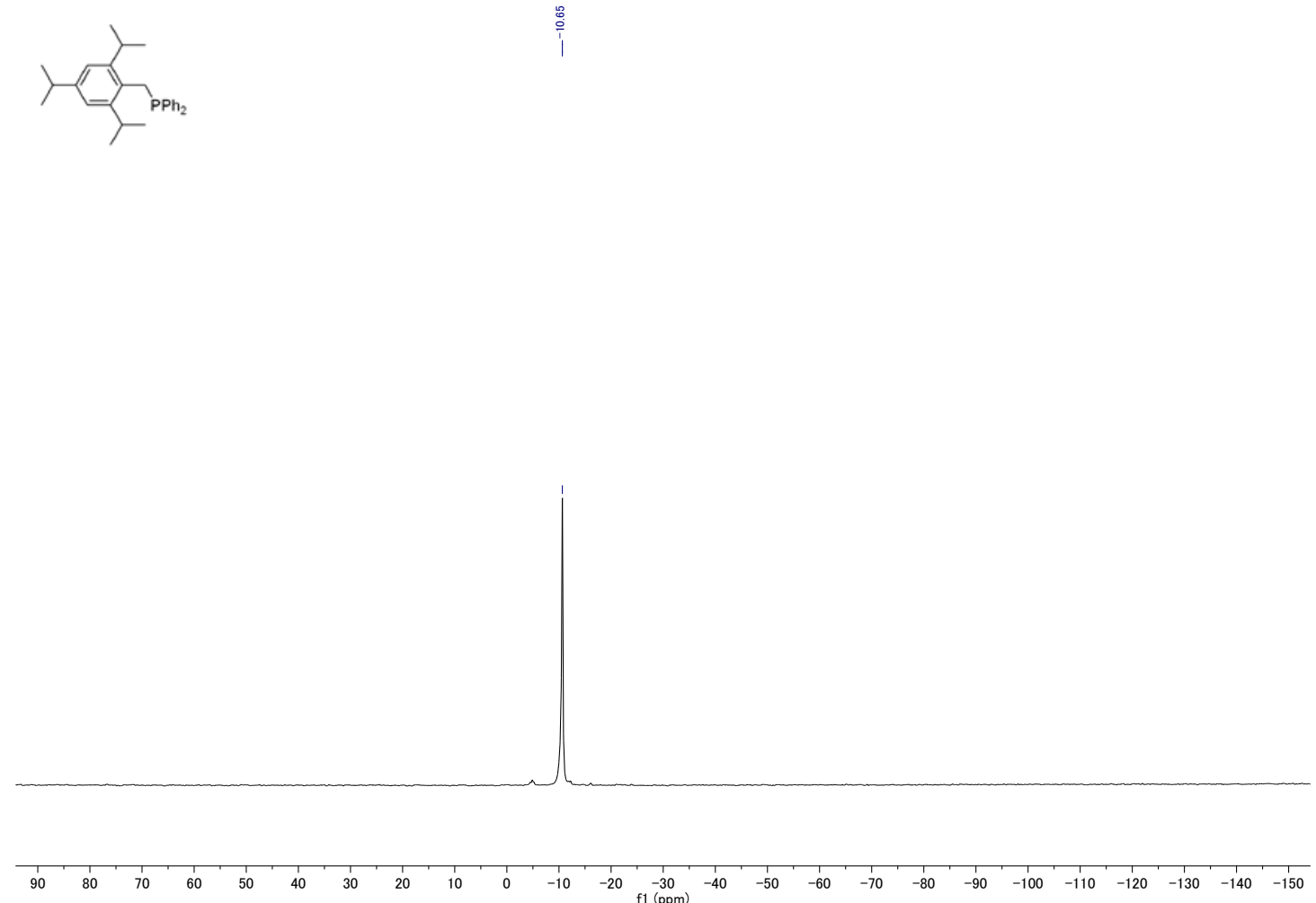
$\begin{array}{lllllll}\text { Figure } & \text { S132: } & { }^{1} \mathrm{H} & \text { NMR } & (400 \quad \mathrm{MHz}, & \text { Chloroform- } d) & \text { for }\end{array}$ diphenyl(2,4,6-triisopropylbenzyl)phosphine(2w).

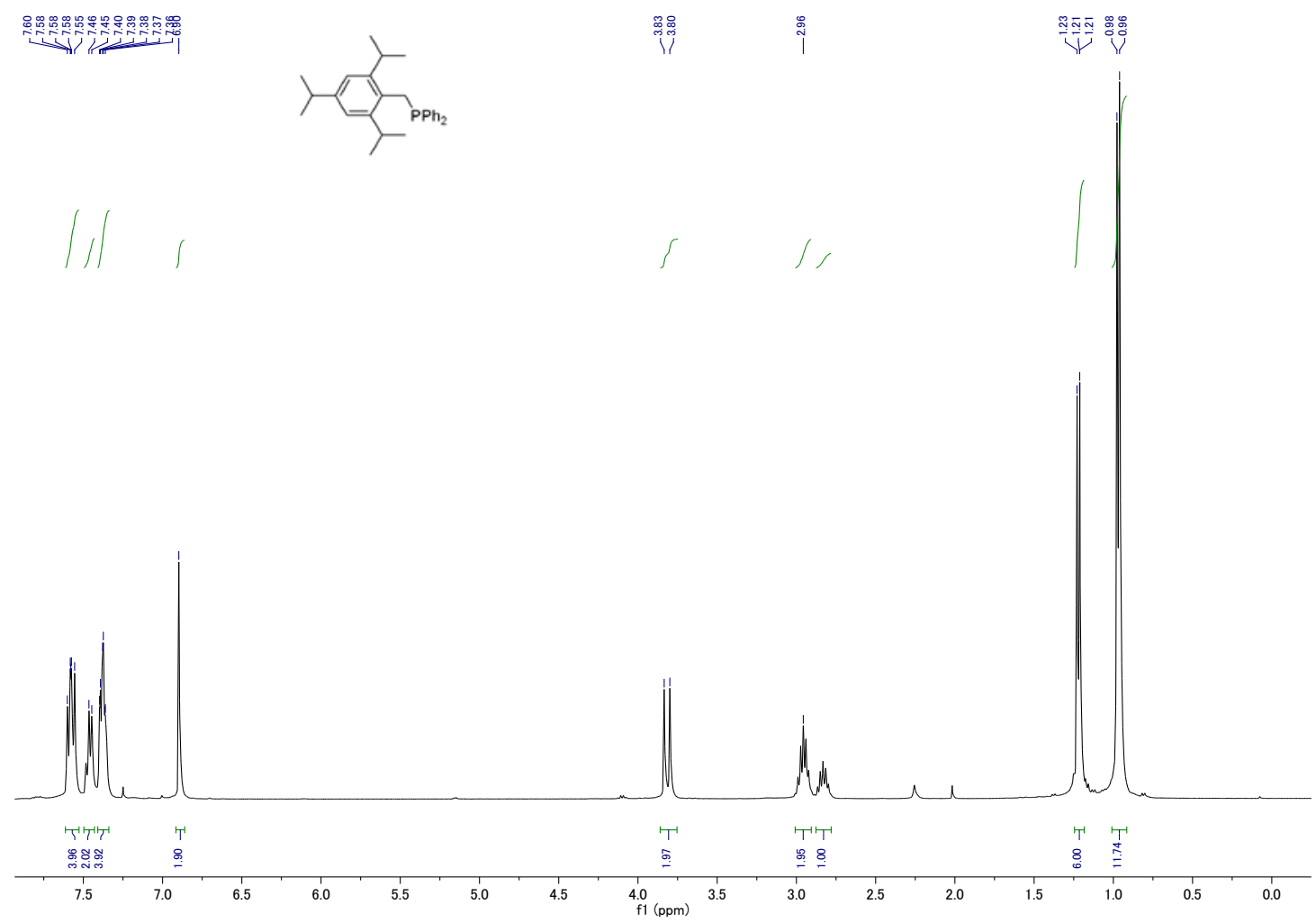

$\begin{array}{lllllll}\text { Figure } & \text { S133: } & { }^{13} \mathrm{C} & \text { NMR } & (101 & \mathrm{MHz}, & \text { Chloroform- } d)\end{array}$ diphenyl(2,4,6-triisopropylbenzyl)phosphine (2w).
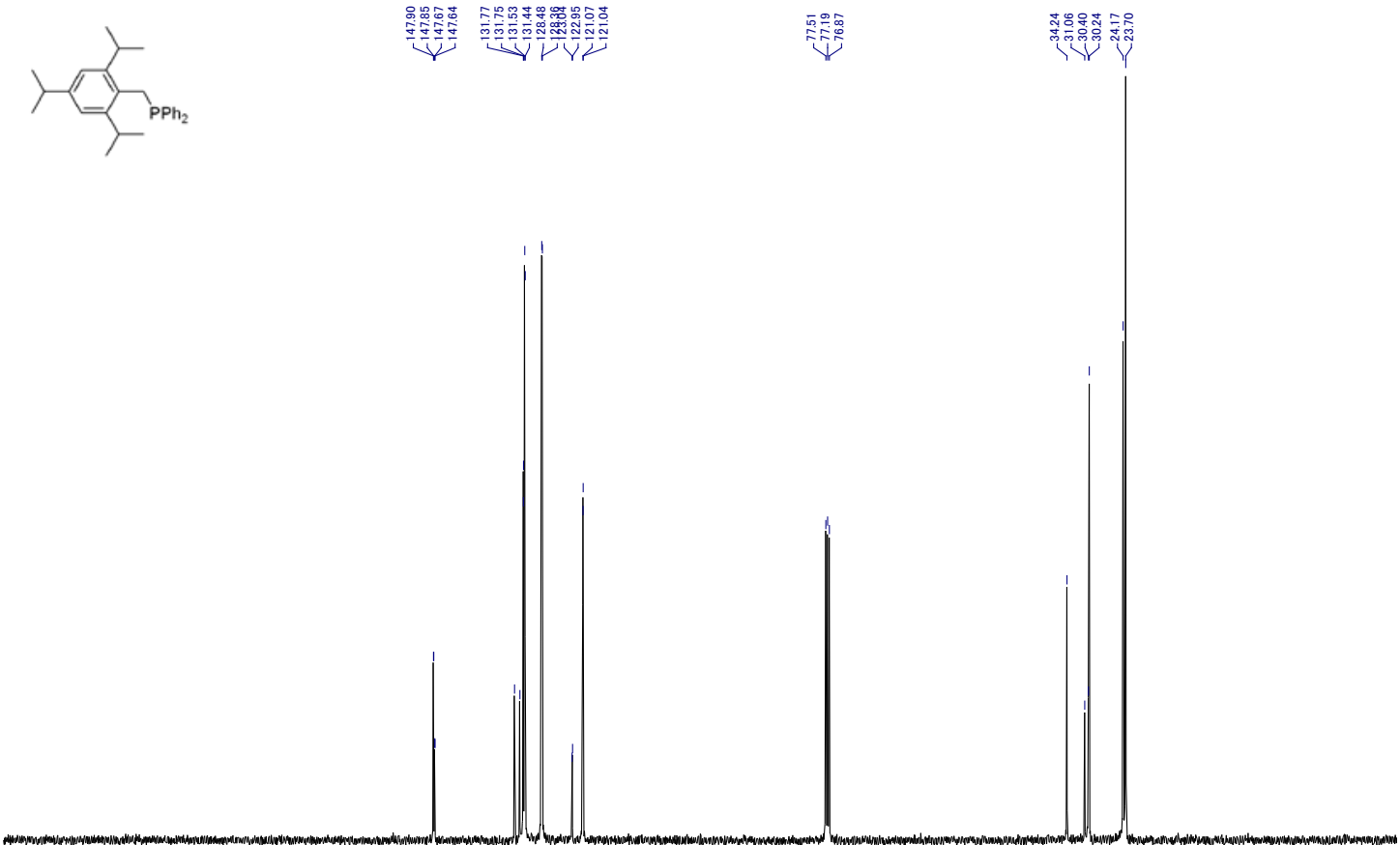

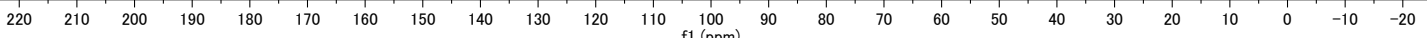


Figure S134: ${ }^{31} \mathrm{P}$ NMR (162 MHz, Chloroform-d) for diphenyl(1-phenylethylphosphine oxide $(4 x)$.
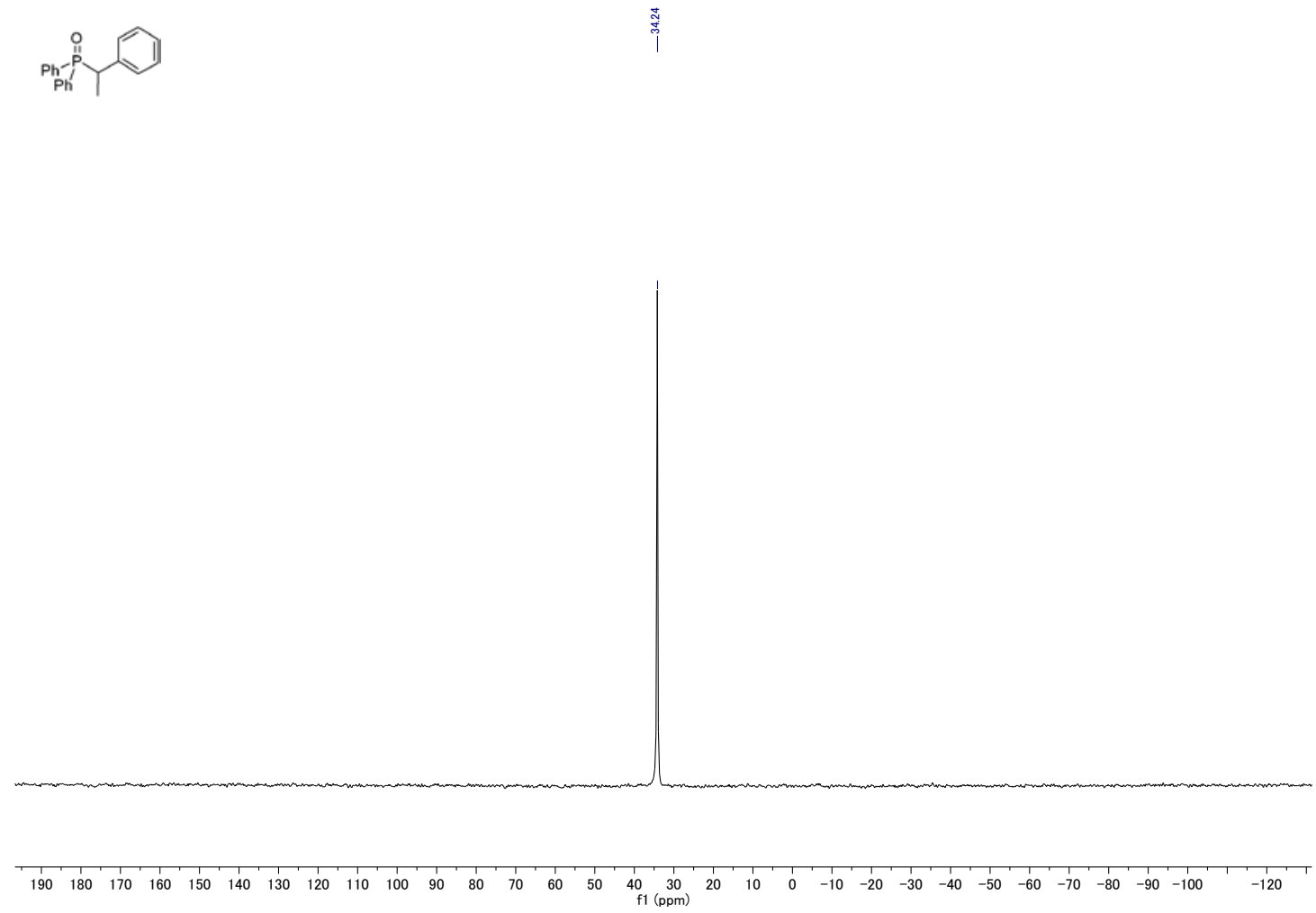

Figure S135: ${ }^{1} \mathrm{H}$ NMR (400 MHz, Chloroform- $d$ ) for diphenyl(1-phenylethylphosphine oxide( $\mathbf{4 x})$.

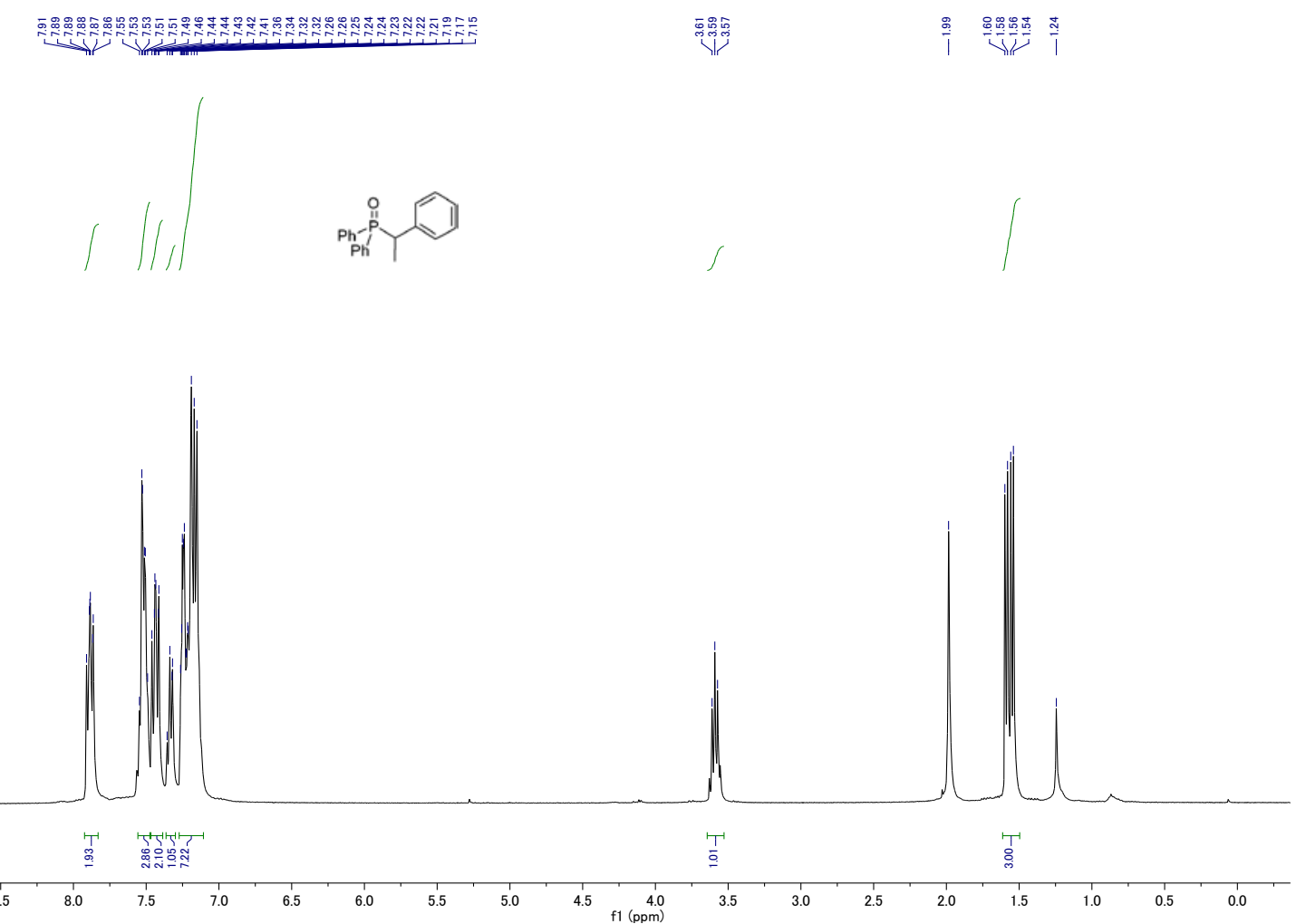


Figure S136: ${ }^{13} \mathrm{C}$ NMR (101 MHz, Chloroform- $d$ ) for diphenyl(1-phenylethylphosphine oxide( $4 \mathbf{x})$.
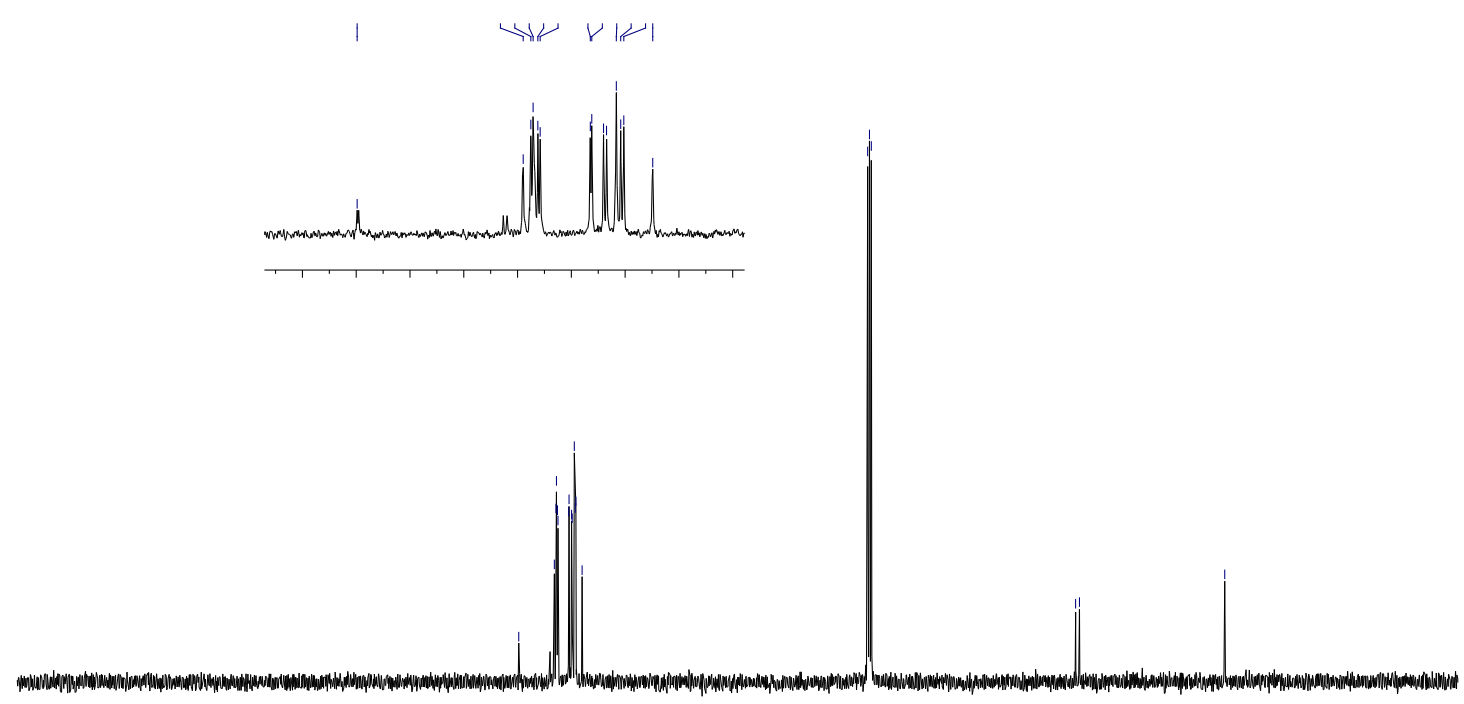

Figure S137: ${ }^{31} \mathrm{P}$ NMR (162 MHz, Chloroform- $d$ ) for cyclohexyldiphenylphosphane oxide (4y).

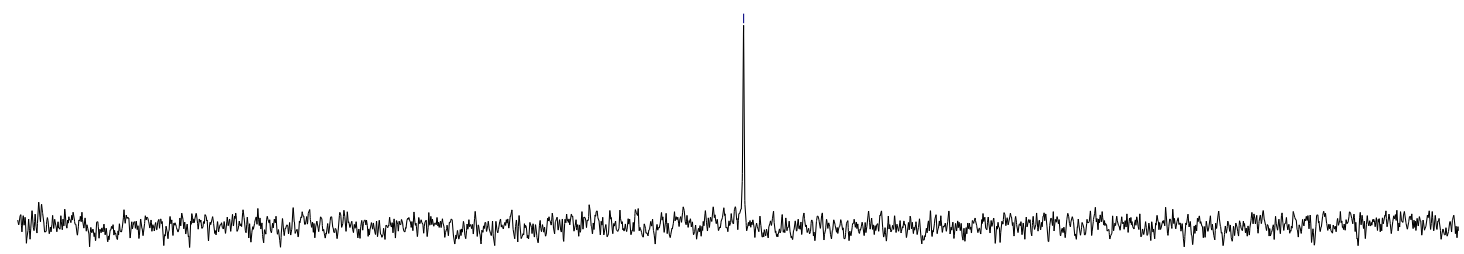


Figure S138: ${ }^{1} \mathrm{H}$ NMR (400 MHz, Chloroform- $d$ ) for cyclohexyldiphenylphosphane oxide (4y).
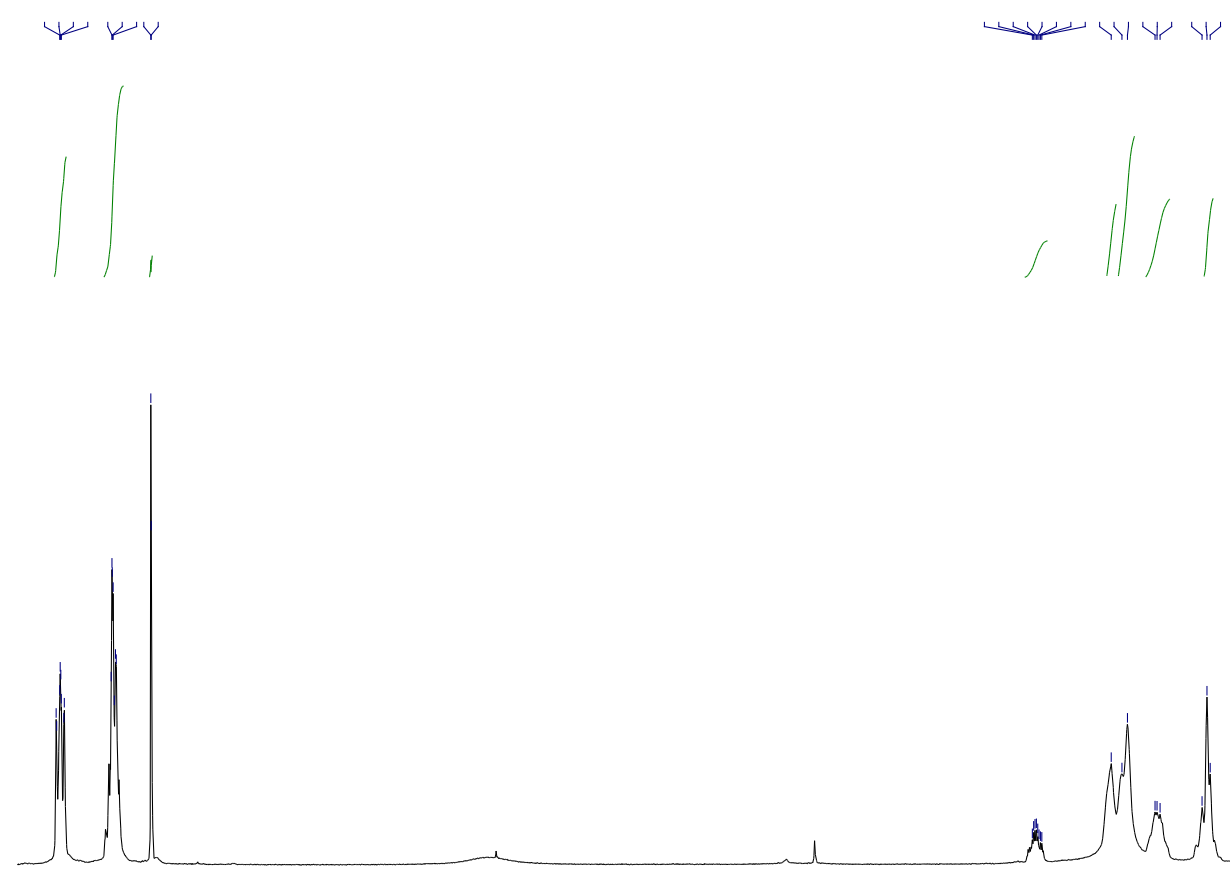

T' T \&

T'T T T

Figure S139: ${ }^{13} \mathrm{C}$ NMR (101 MHz, Chloroform- $d$ ) for cyclohexyldiphenylphosphane oxide (4y). Wr

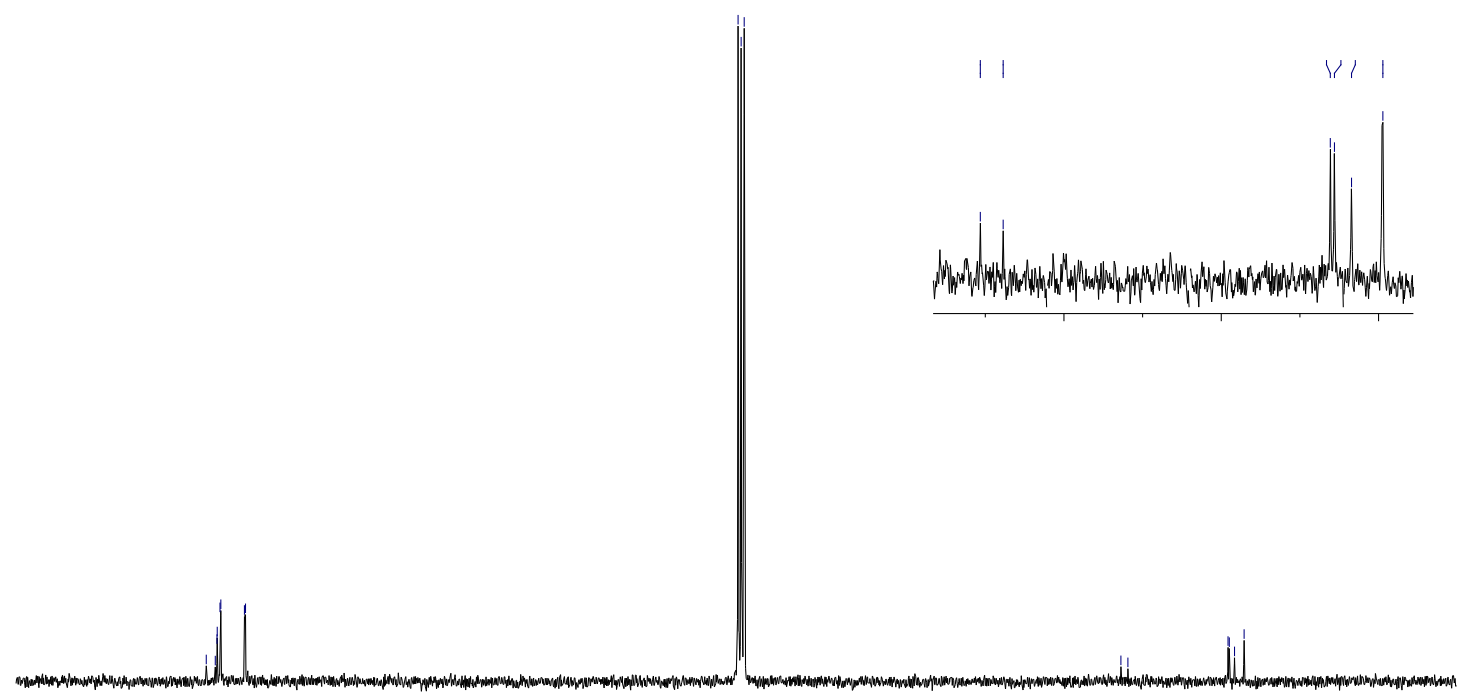


Figure S140: ${ }^{31} \mathrm{P}$ NMR (162 MHz, Chloroform- $d$ ) for (1-adamantyl)diphenylphosphine oxide (4aa).

Figure S141: ${ }^{1} \mathrm{H}$ NMR (400 MHz, Chloroform-d) for (1-adamantyl)diphenylphosphine oxide (4aa).

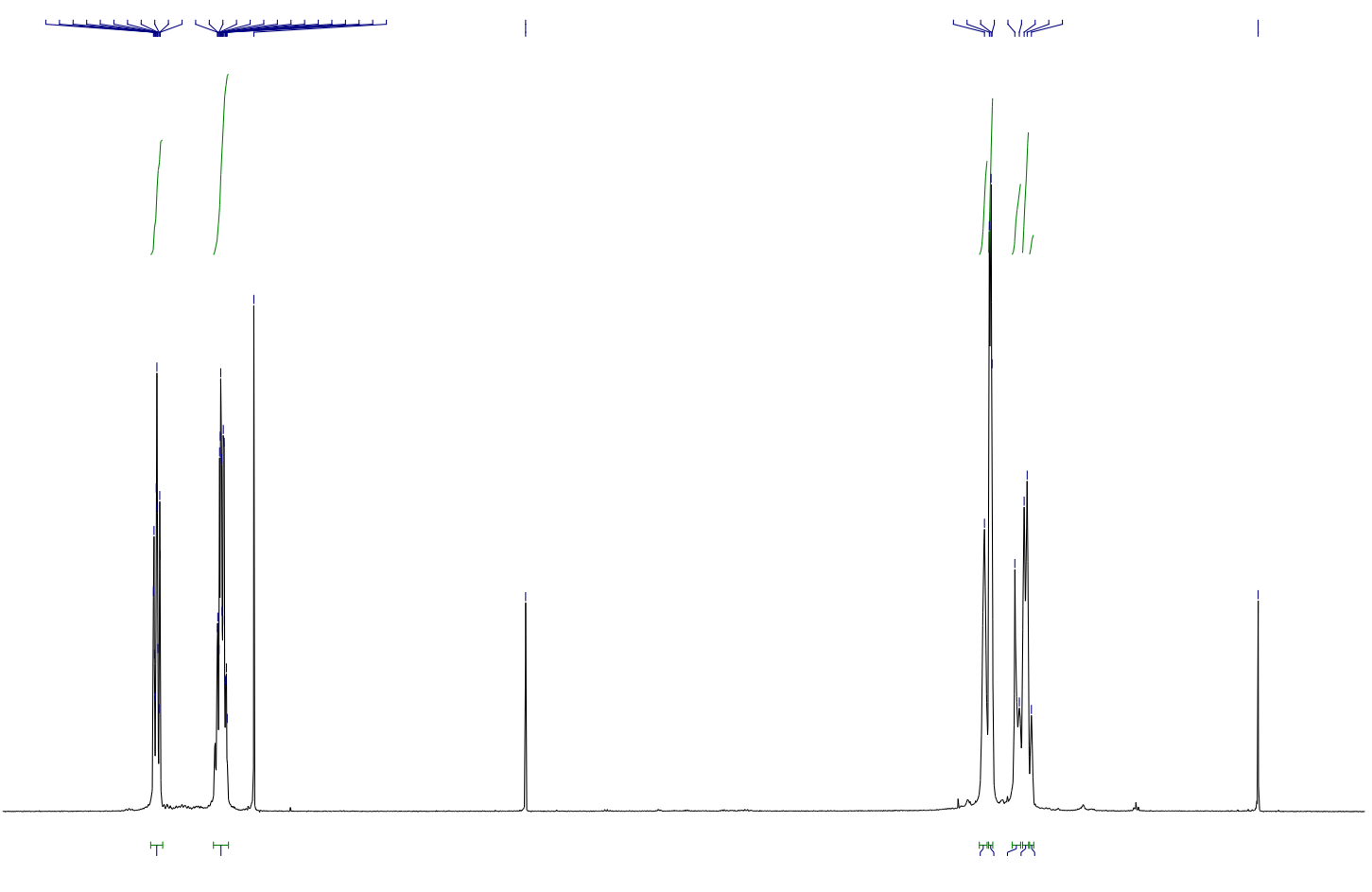


Figure S142: ${ }^{13} \mathrm{C}$ NMR (101 MHz, Chloroform- $d$ ) for (1-adamantyl)diphenylphosphine oxide (4aa).

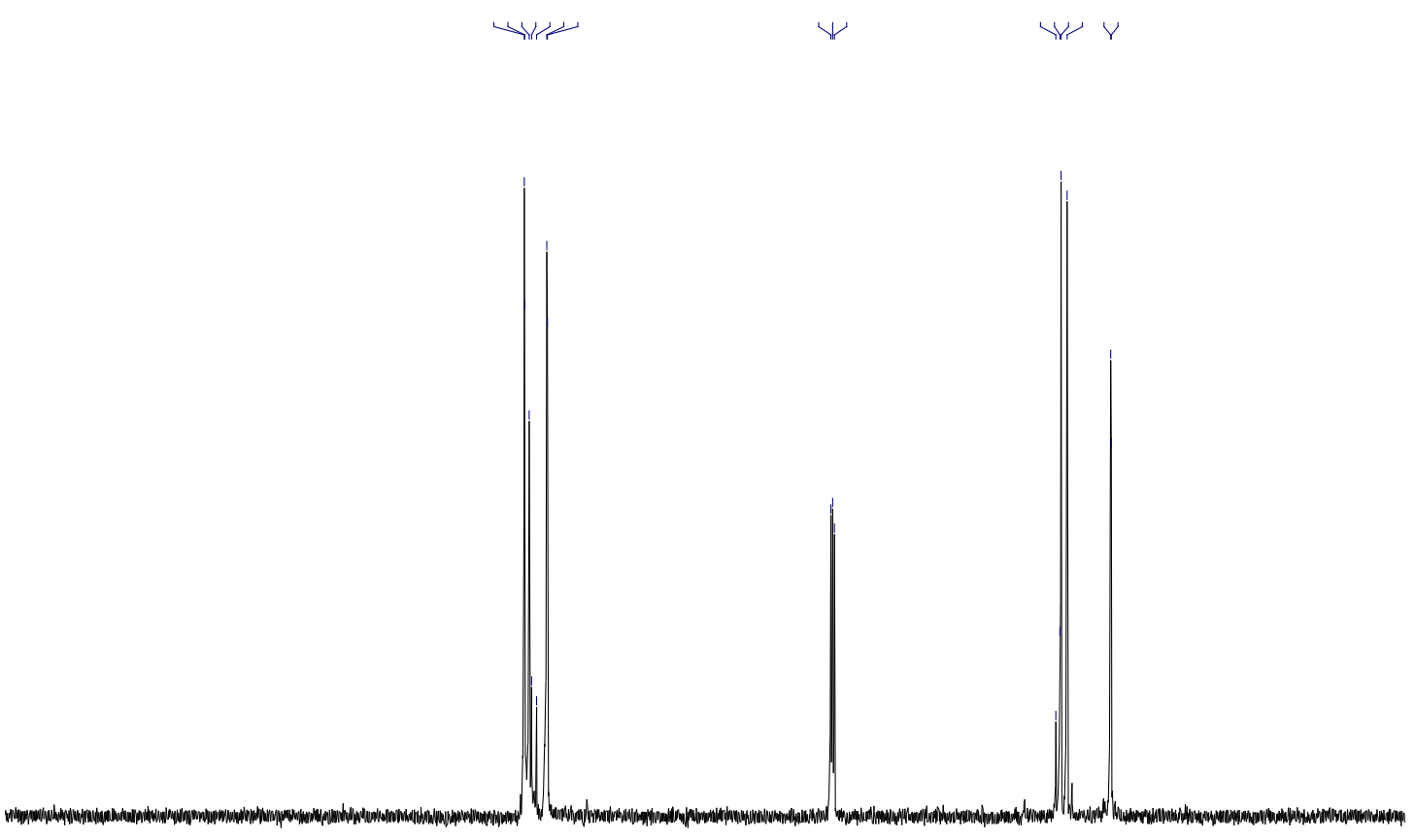

Figure S143: ${ }^{31} \mathrm{P}$ NMR (162 MHz, Chloroform-d) for methyldiphenylphosphine (4ab). 
Figure S144: ${ }^{1} \mathrm{H}$ NMR (400 MHz, Chloroform- $d$ ) for methyldiphenylphosphine (4ab).

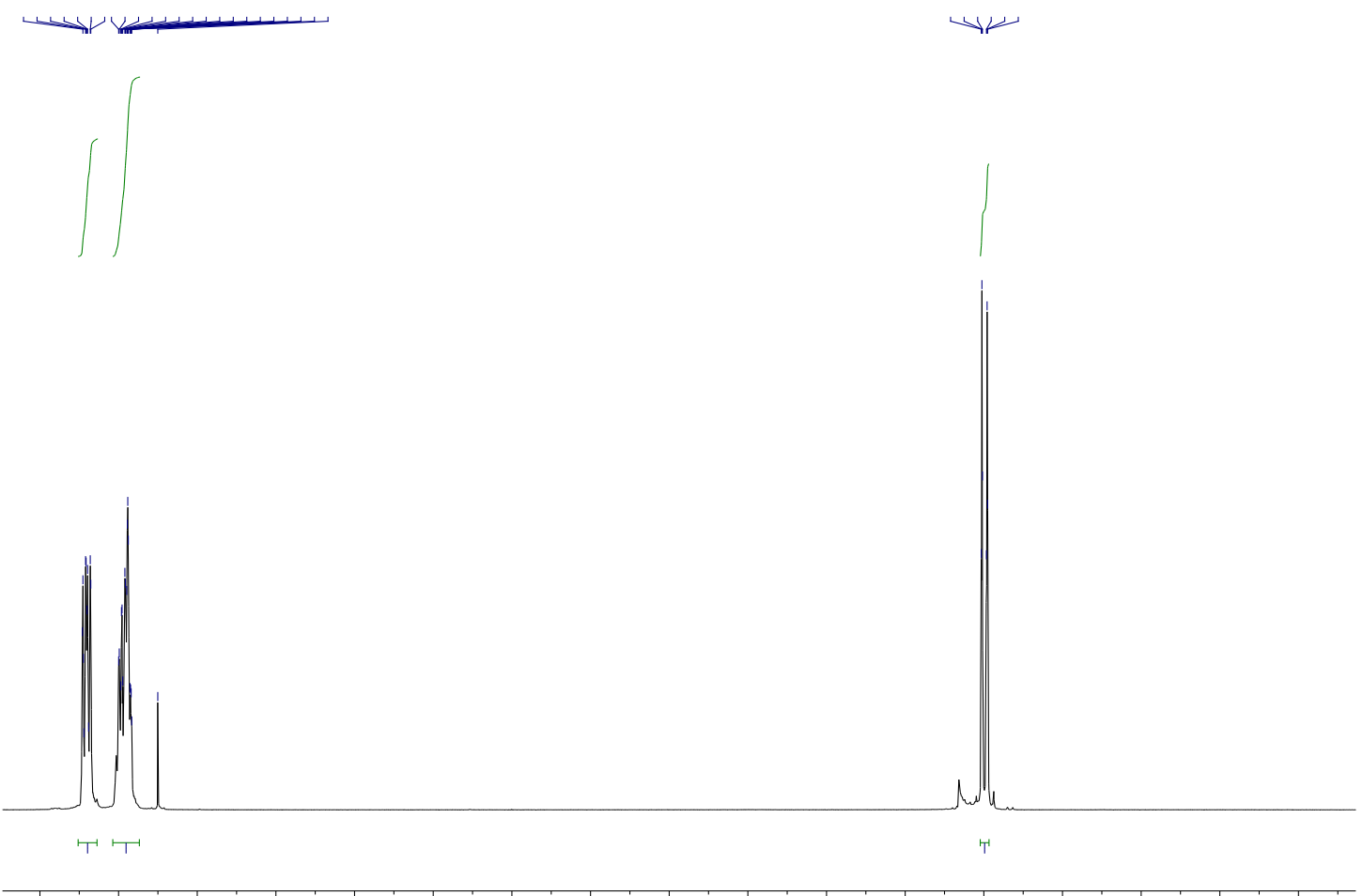

Figure S145: ${ }^{13} \mathrm{C}$ NMR (101 MHz, Chloroform- $d$ ) for methyldiphenylphosphine (4ab).

$$
\text { Nor }
$$

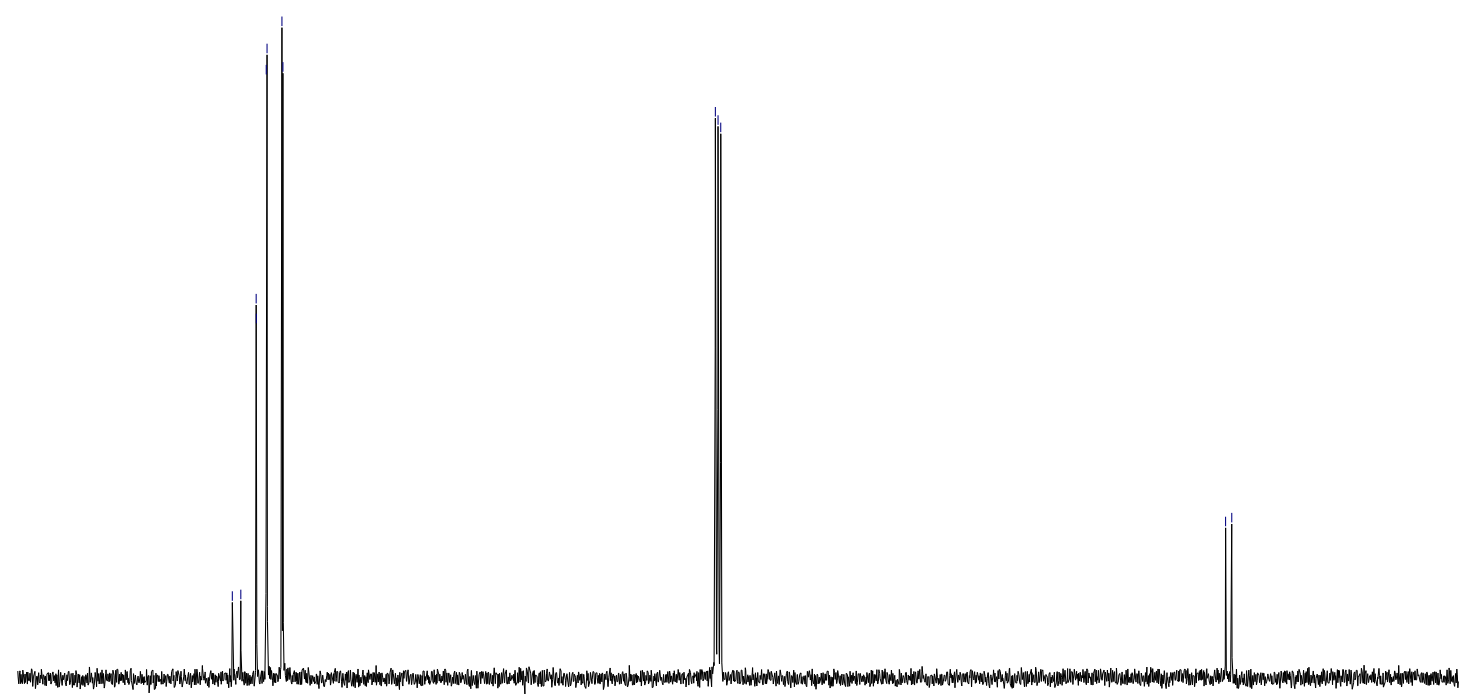


Figure S146: ${ }^{31} \mathrm{P}$ NMR (162 MHz, Chloroform- $d$ ) for $p$-tolylmethylphenylphosphine (2ac).

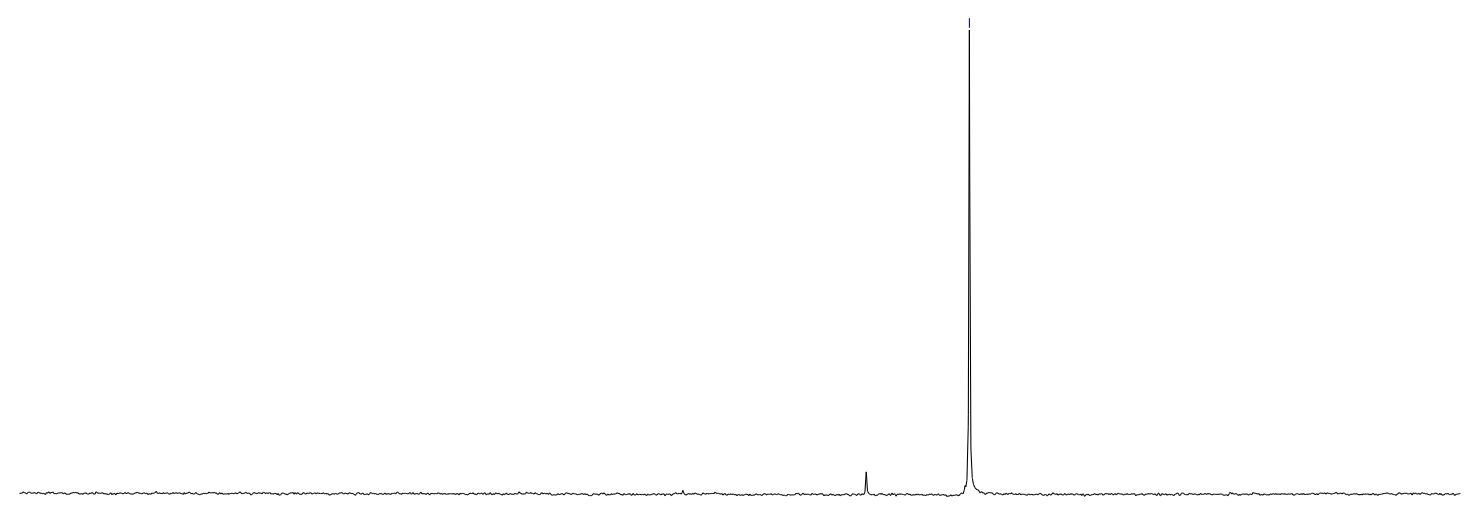

Figure S147: ${ }^{1} \mathrm{H}$ NMR (400 MHz, Chloroform- $d$ ) for $p$-tolylmethylphenylphosphine (2ac).

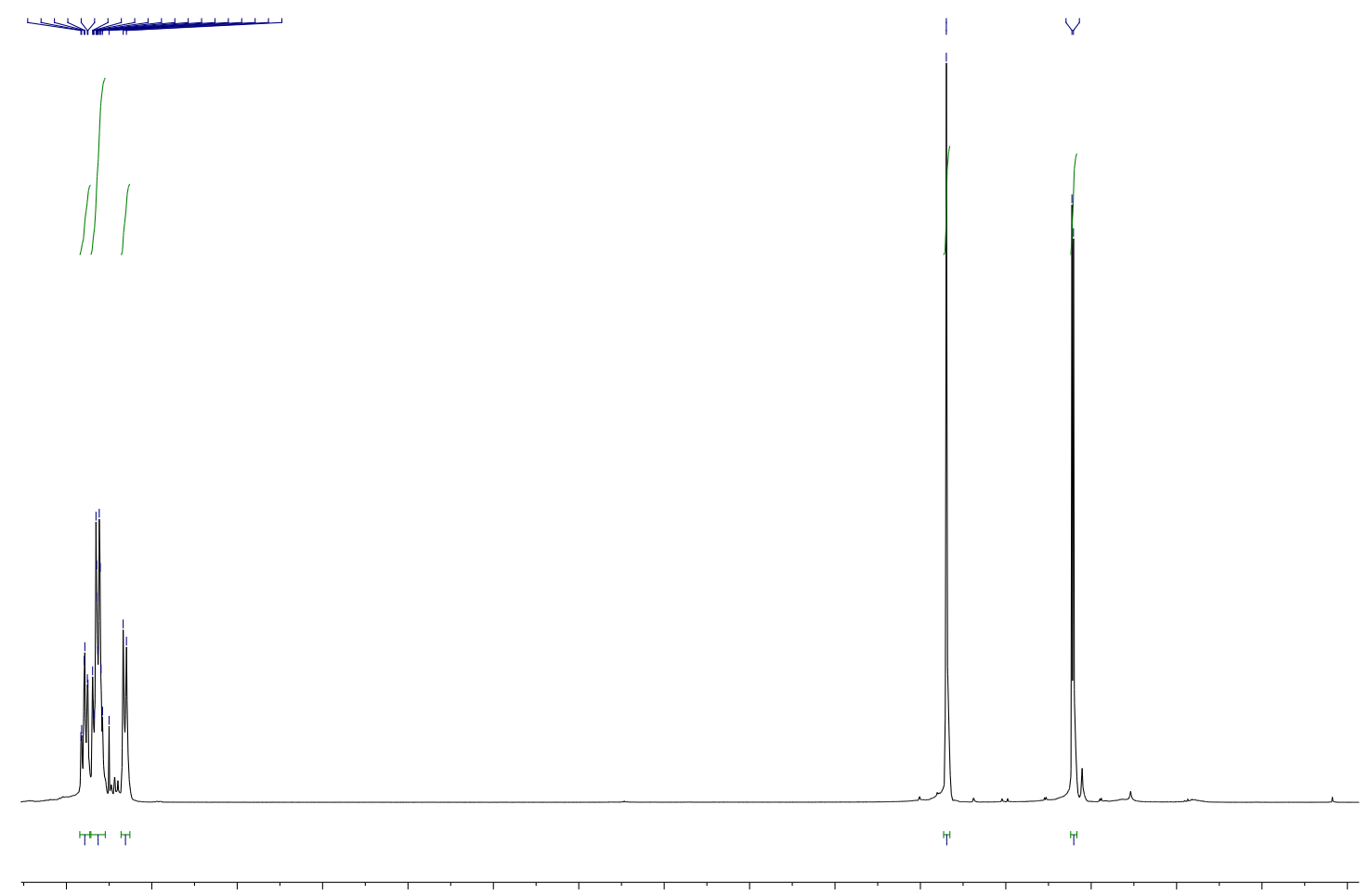


Figure S148: ${ }^{13} \mathrm{C}$ NMR (101 MHz, Chloroform- $d$ ) for $p$-tolylmethylphenylphosphine (2ac).
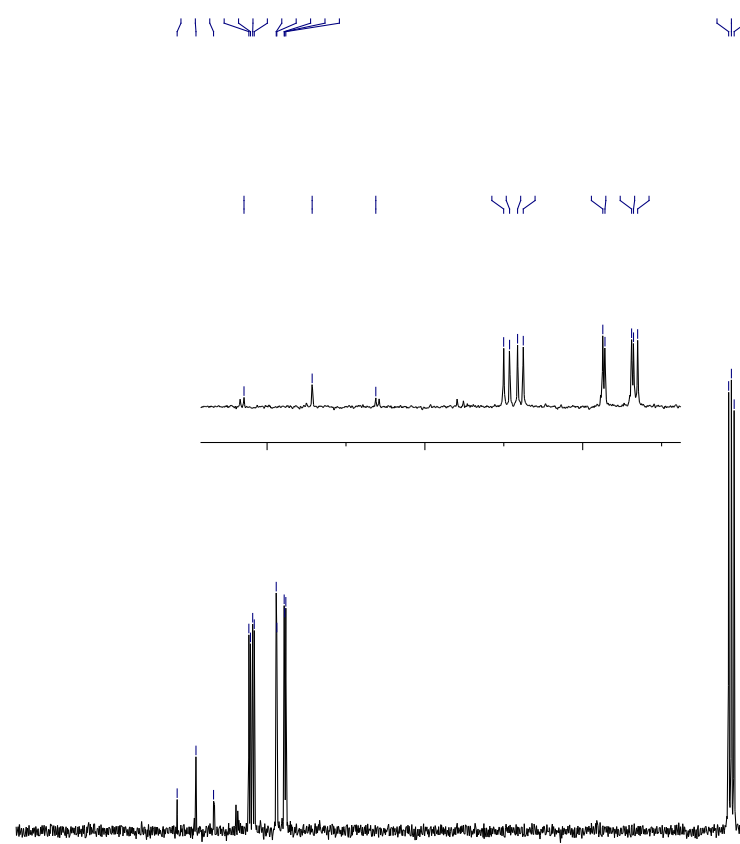

Figure S149: ${ }^{31} \mathrm{P}$ NMR (162 MHz, Chloroform-d) for 4-tert-butylphenyl methylphenylphosphine oxide (4ad). 
Figure S150: ${ }^{1} \mathrm{H}$ NMR (400 MHz, Chloroform-d) for 4-tert-butylphenyl methylphenylphosphine oxide (4ad).

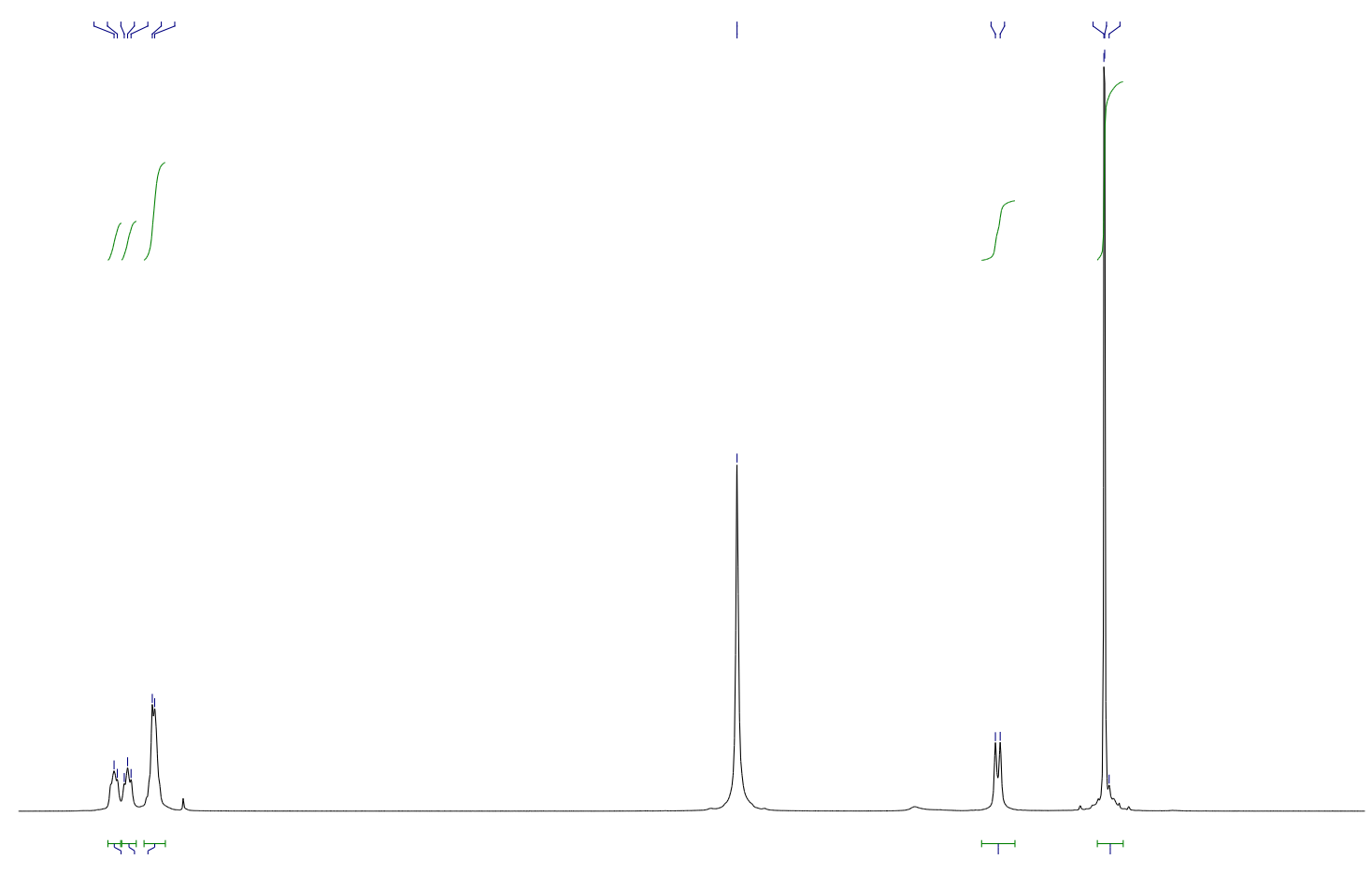

Figure S151: ${ }^{13} \mathrm{C}$ NMR (101 MHz, Chloroform- $d$ ) for 4-tert-butylphenyl methylphenylphosphine oxide (4ad).

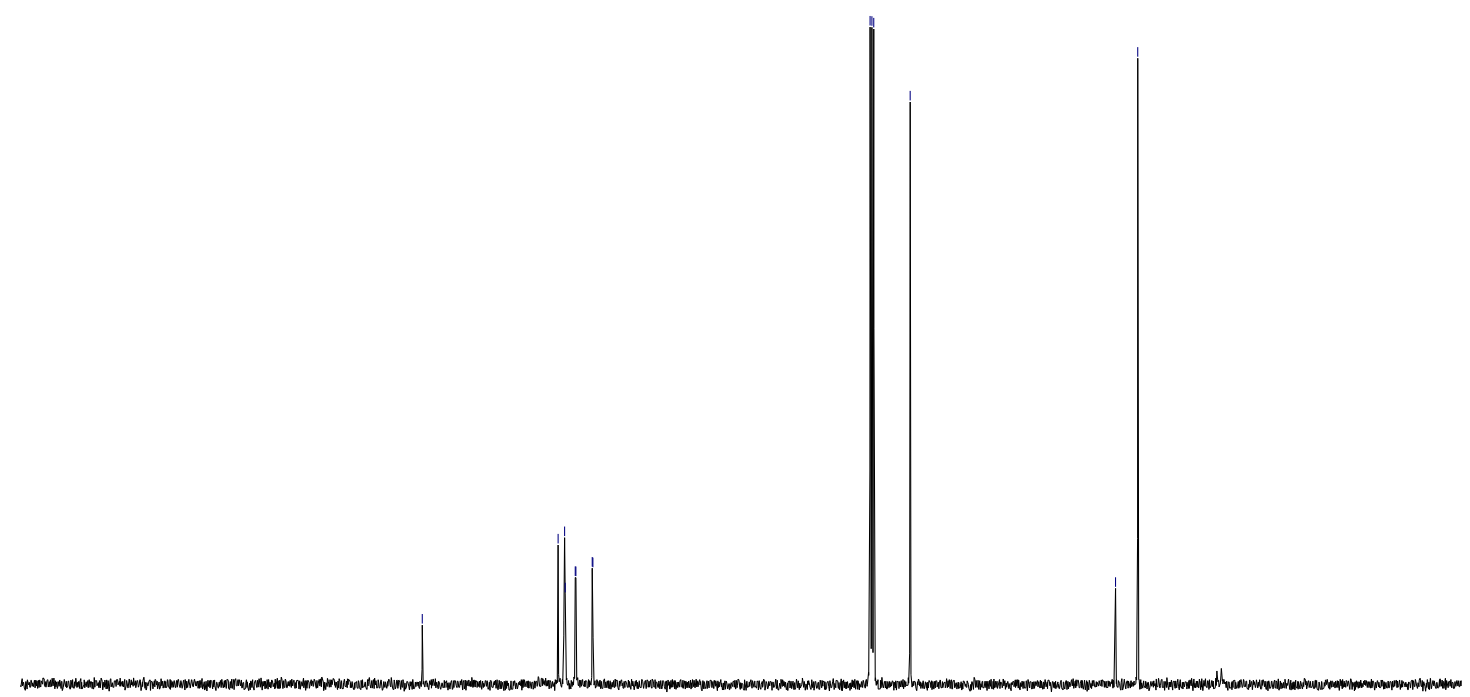


Figure S152: ${ }^{31}$ P NMR (162 MHz, Chloroform- $d$ ) for $n$-butyl diphenylphosphine (2ae).

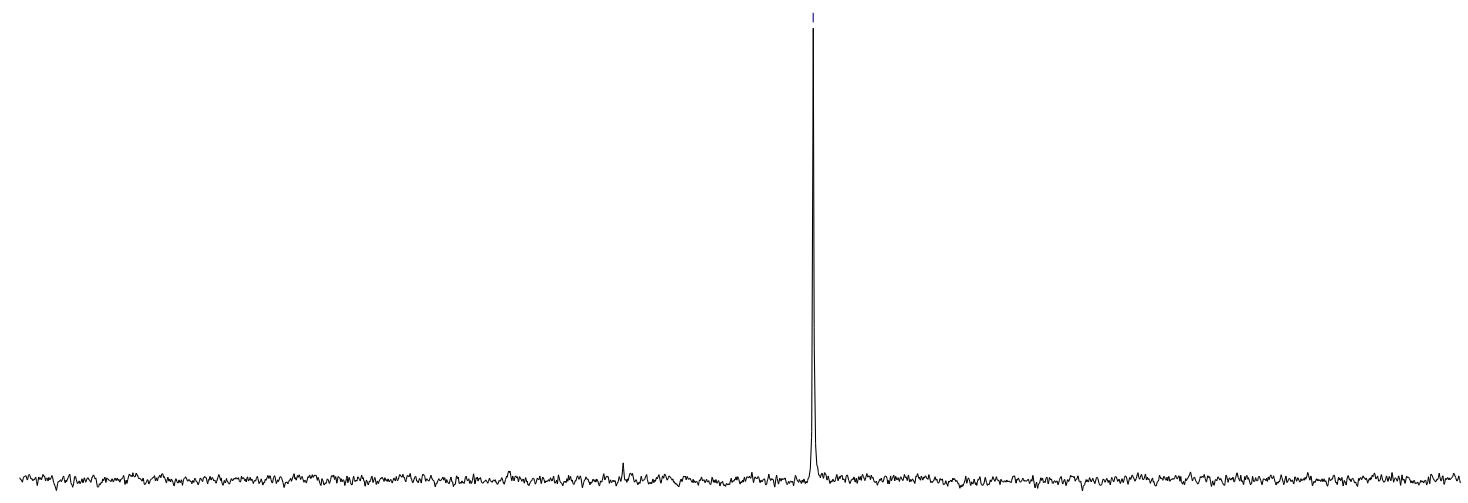

Figure S153: ${ }^{1} \mathrm{H}$ NMR (400 MHz, Chloroform- $d$ ) for $n$-butyldiphenylphosphine (2ae).
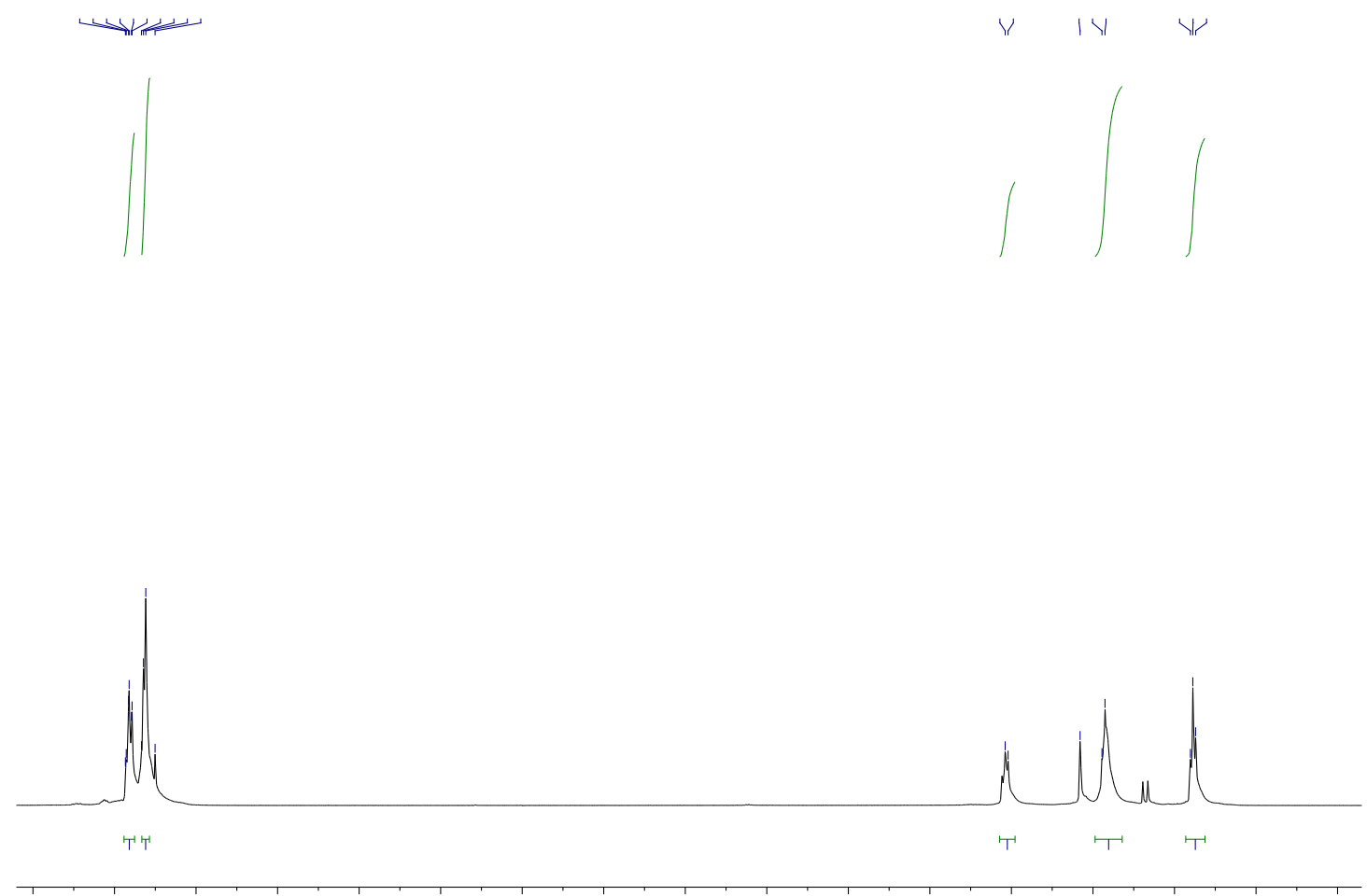
Figure S154: ${ }^{13} \mathrm{C}$ NMR (101 MHz, Chloroform- $d$ ) for n-butyldiphenylphosphine (2ae).
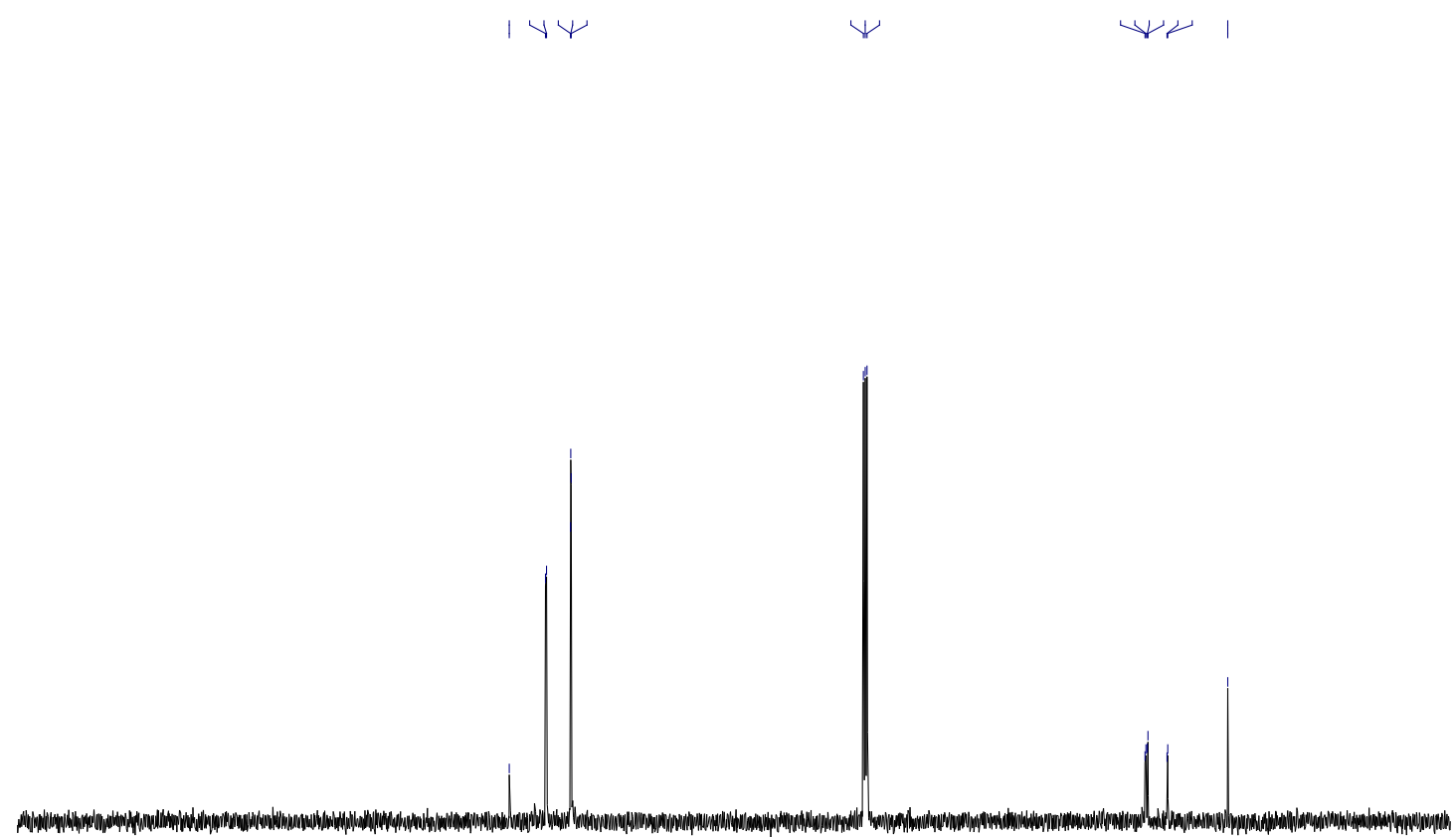

Figure S155: ${ }^{31} \mathrm{P}$ NMR (162 MHz, Chloroform- $d$ ) for 2-naphthyl $n$-butylphenylphosphane (2af). 
Figure S156: ${ }^{1} \mathrm{H}$ NMR (400 MHz, Chloroform-d) for 2-naphthyln-butylphenylphosphane (2af).

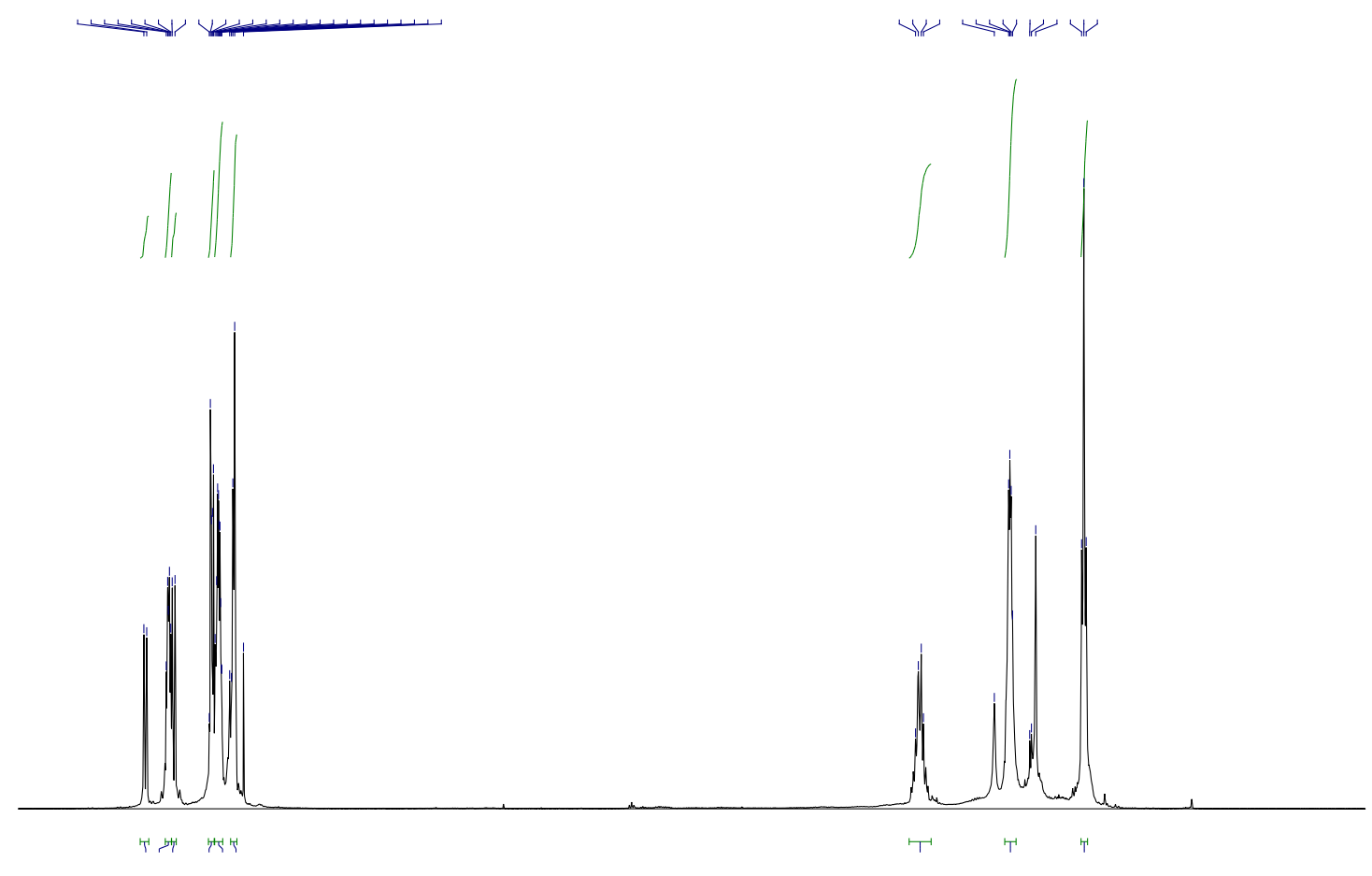

Figure S157: ${ }^{13} \mathrm{C}$ NMR (101 MHz, Chloroform- $d$ ) for 2-naphthyln-butylphenylphosphane (2af).

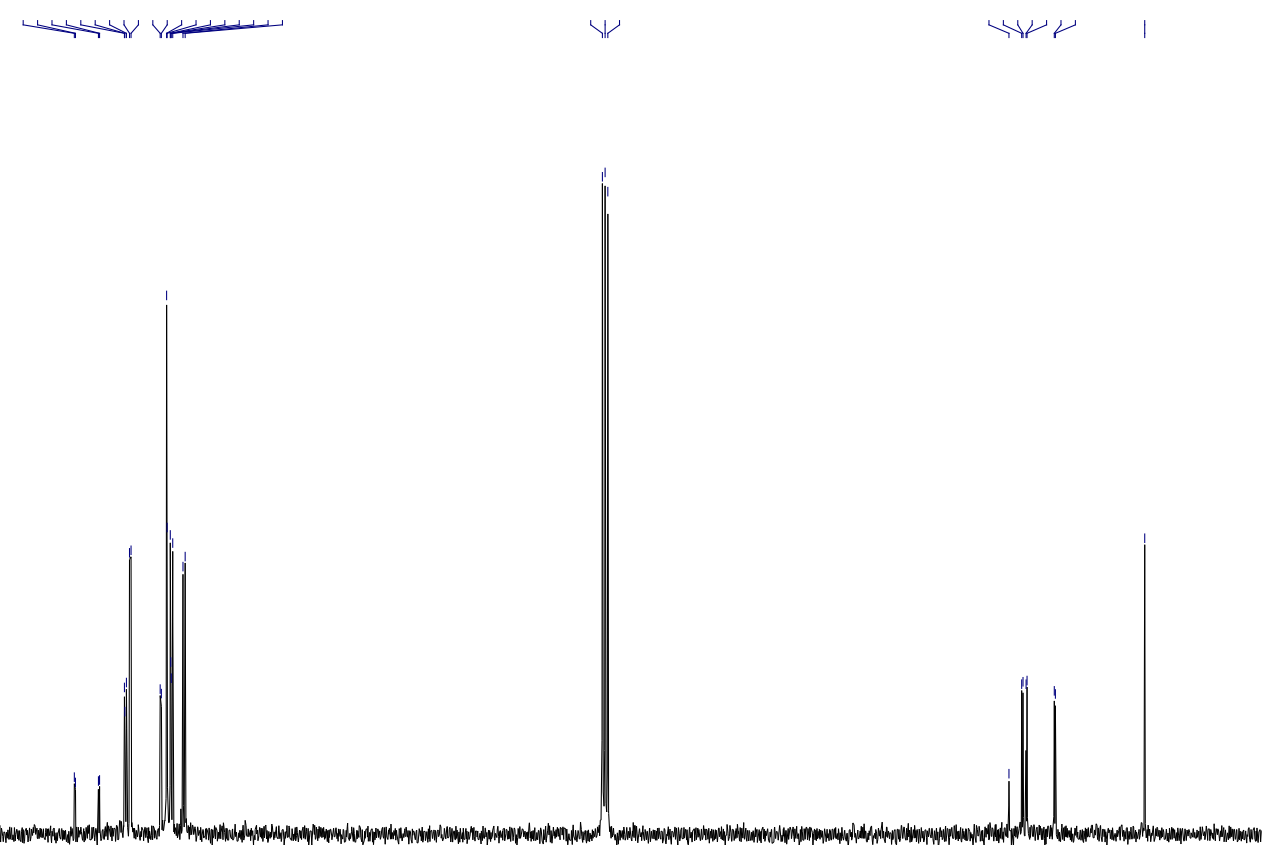


Figure S158: ${ }^{31} \mathrm{P}$ NMR (162 MHz, Chloroform- $d$ ) for di-n-butylphenylphosphine oxide (4ag).

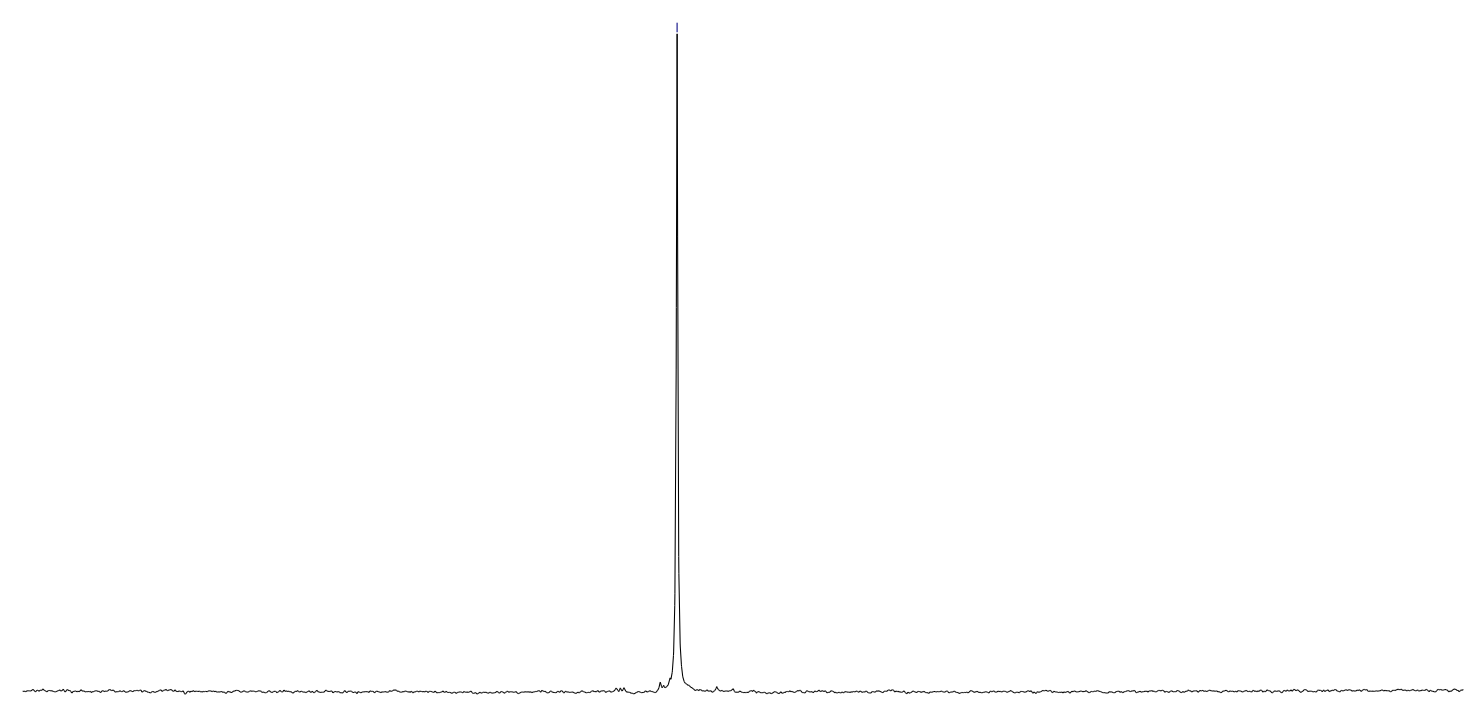

Figure S159: ${ }^{1} \mathrm{H}$ NMR (400 MHz, Chloroform- $d$ ) for di- $n$-butylphenylphosphine oxide (4ag).

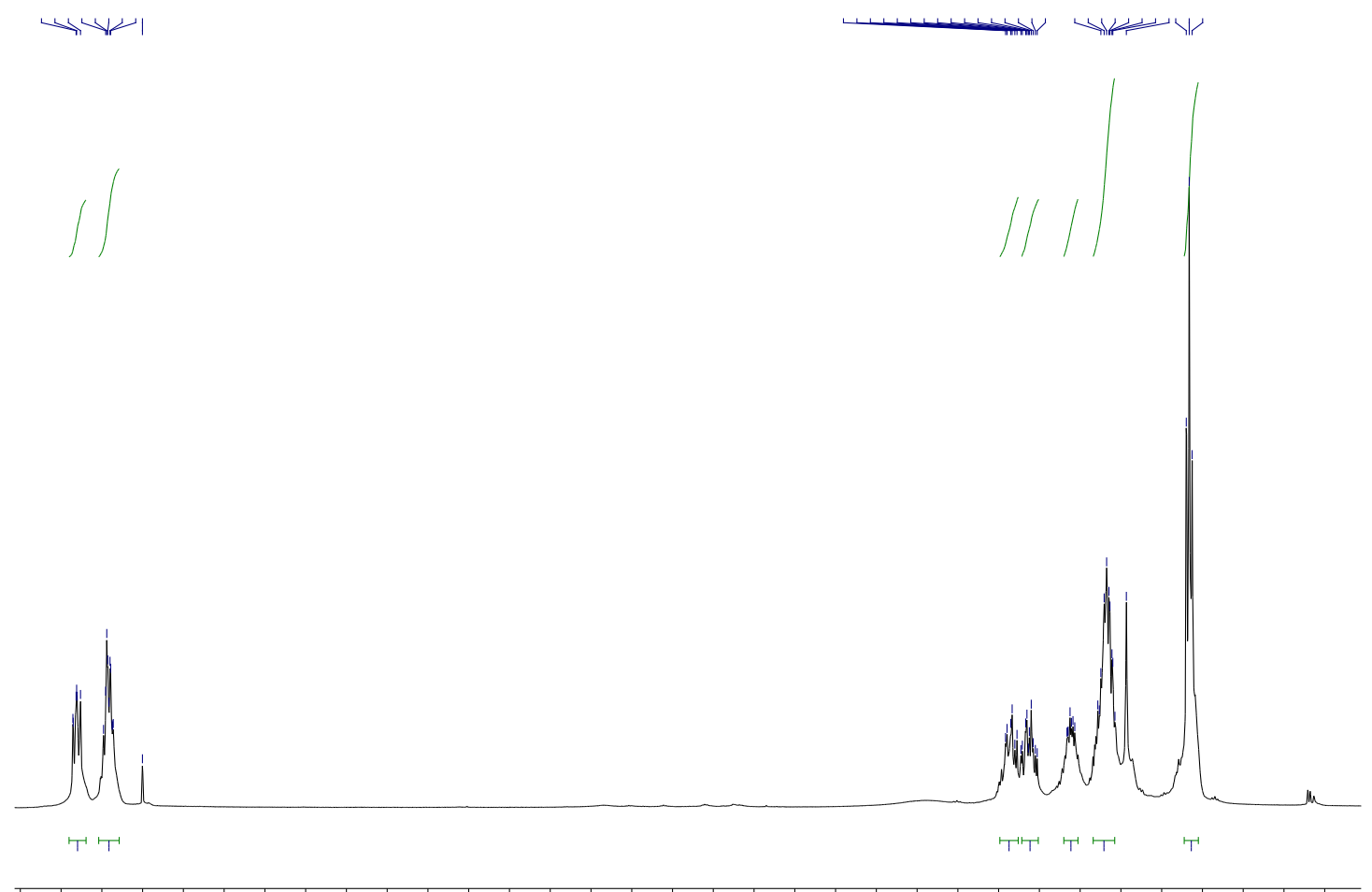


Figure S160: ${ }^{13} \mathrm{C}$ NMR (101 MHz, Chloroform- $d$ ) for di-n-butylphenylphosphine oxide (4ag).

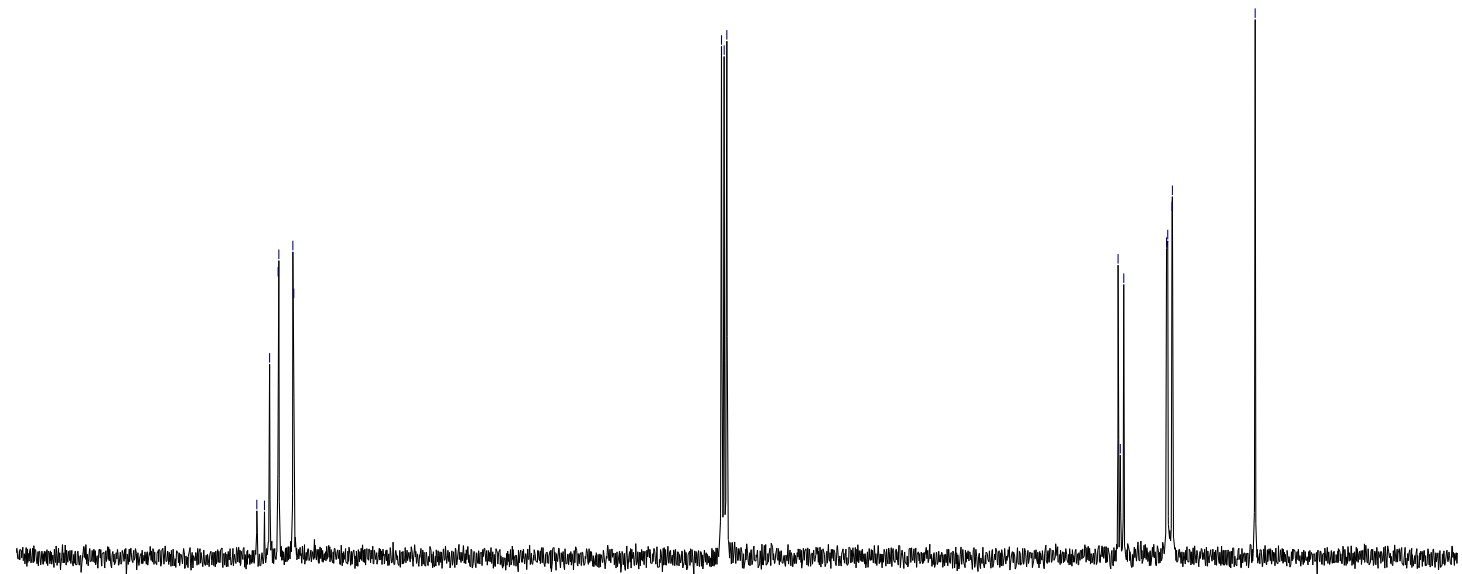

Figure S161: ${ }^{31} \mathrm{P}$ NMR (162 MHz, Chloroform-d) for 1,3,5-tris(methylphenylphosphoryl)benzene (4ah). 
Figure S162: ${ }^{1} \mathrm{H}$ NMR (400 MHz, Chloroform- $d$ ) for 1,3,5-tris(methylphenylphosphoryl)benzene (4ah).

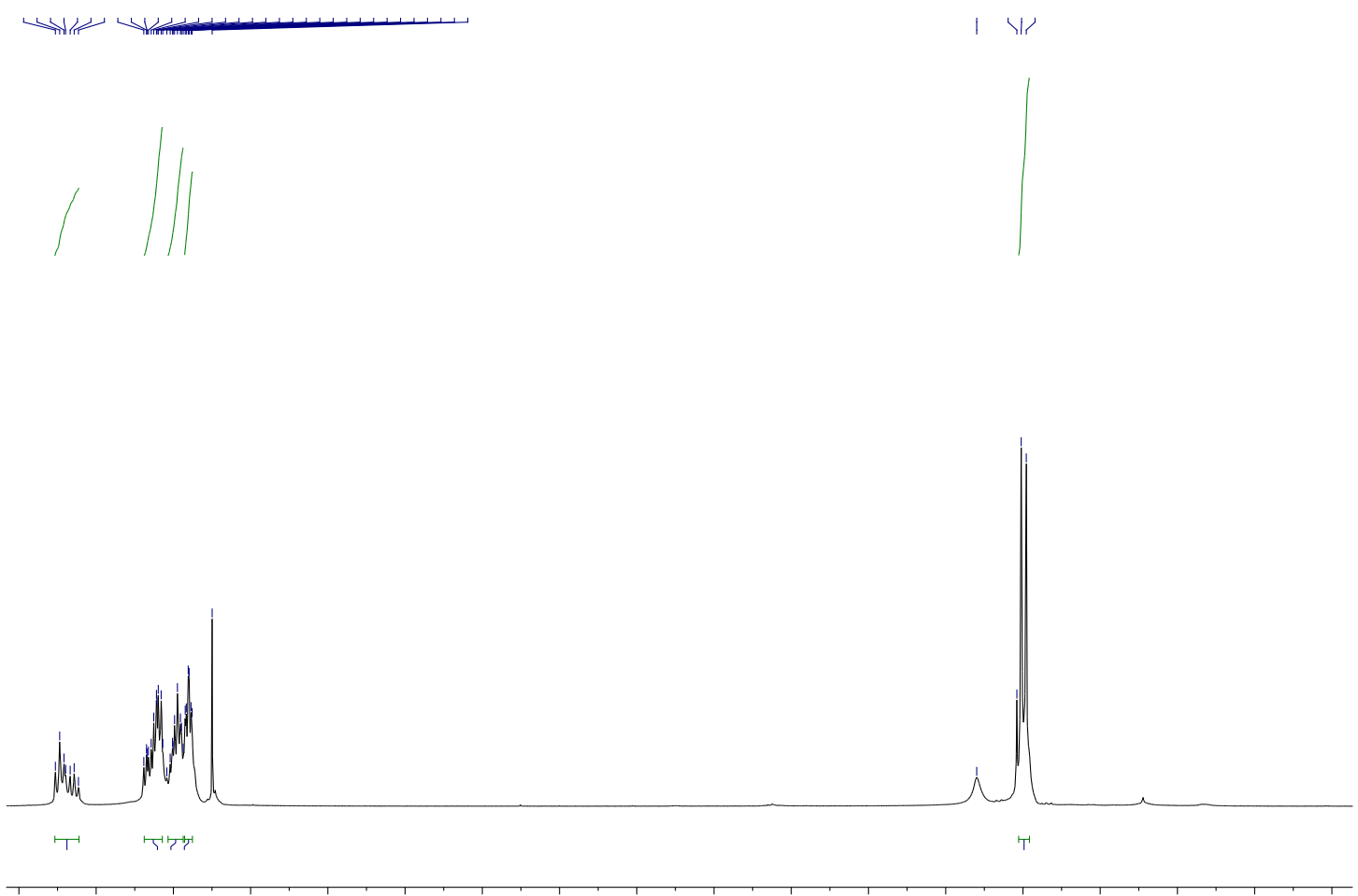

Figure S163: ${ }^{13} \mathrm{C}$ NMR (101 MHz, Chloroform- $d$ ) for 1,3,5-tris(methylphenylphosphoryl)benzene (4ah). 
$\begin{array}{lllllll}\text { Figure } & \text { S164: } & { }^{31} \mathrm{P} & \text { NMR } & (162 & \mathrm{MHz}, & \text { Chloroform- } d)\end{array}$ (3-diphenylphosphino)phenylmethylphenylphosphine oxide (4ai).

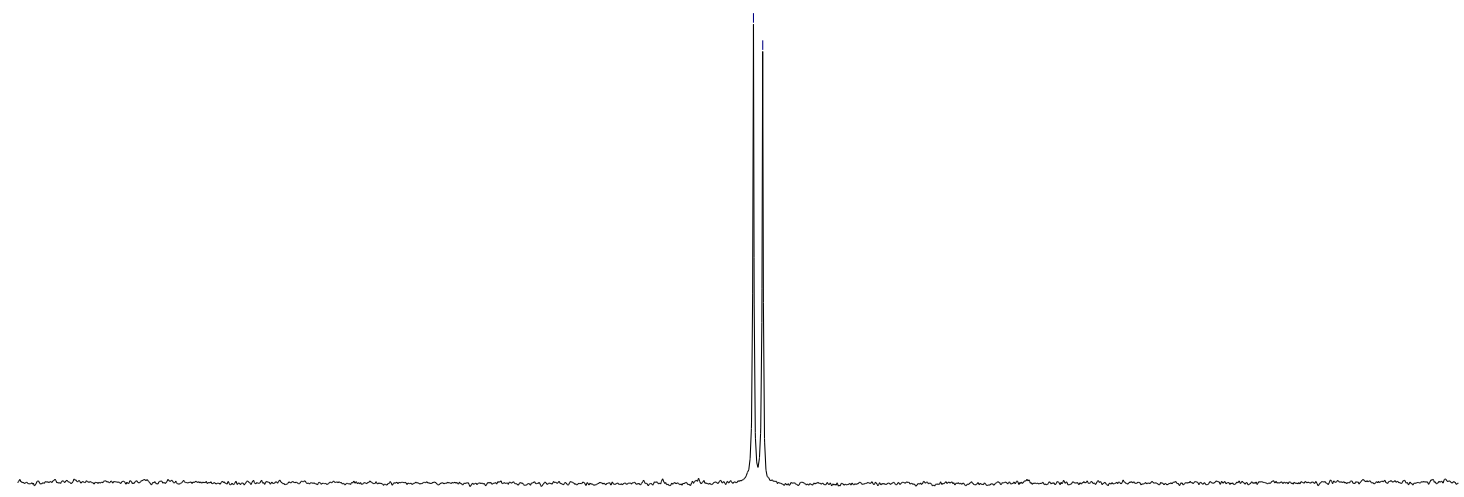

$\begin{array}{lllllll}\text { Figure } & \text { S165: } & { }^{1} \mathrm{H} & \mathrm{NMR} & (400 \quad \mathrm{MHz}, & \text { Chloroform- } d) & \text { for }\end{array}$ (3-diphenylphosphino)phenylmethylphenylphosphine oxide (4ai).

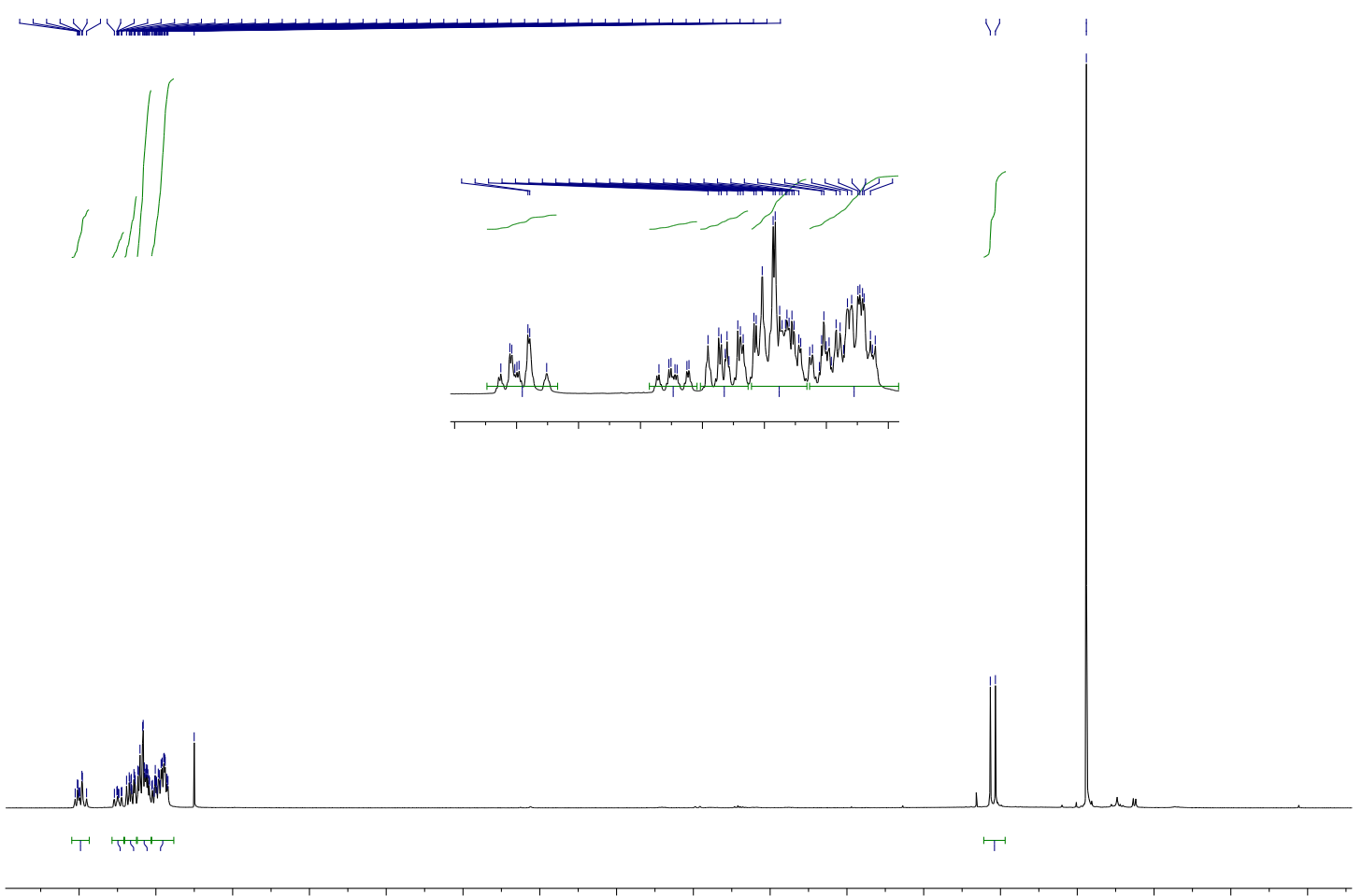




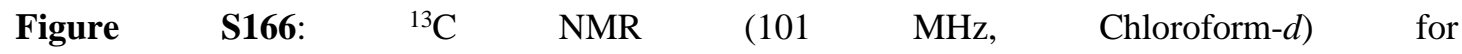
(3-diphenylphosphino)phenylmethylphenylphosphine oxide (4ai).
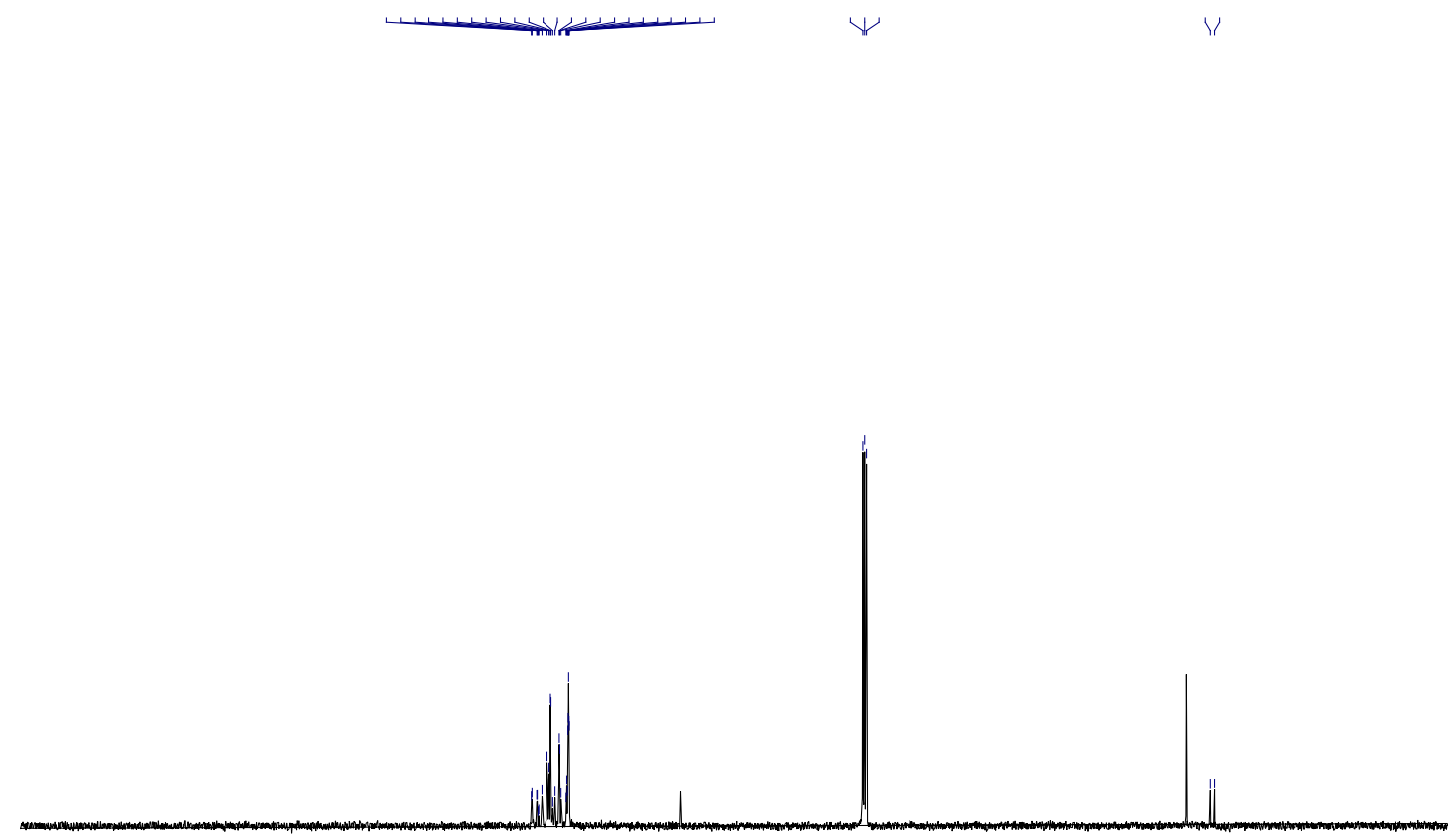

Figure $\quad$ S167: $\quad{ }^{31} \mathrm{P} \quad$ NMR $\quad(162 \quad \mathrm{MHz}, \quad$ Chloroform- $d) \quad$ for 1,4-bis(1-naphthalenylphenylphosphaneyl)butane (2aj). 
$\begin{array}{lllllll}\text { Figure } & \text { S168: } & { }^{1} \mathrm{H} & \text { NMR } & (400 \quad \mathrm{MHz}, & \text { Chloroform- } d) & \text { for }\end{array}$ 1,4-bis(1-naphthalenylphenylphosphaneyl)butane (2aj).

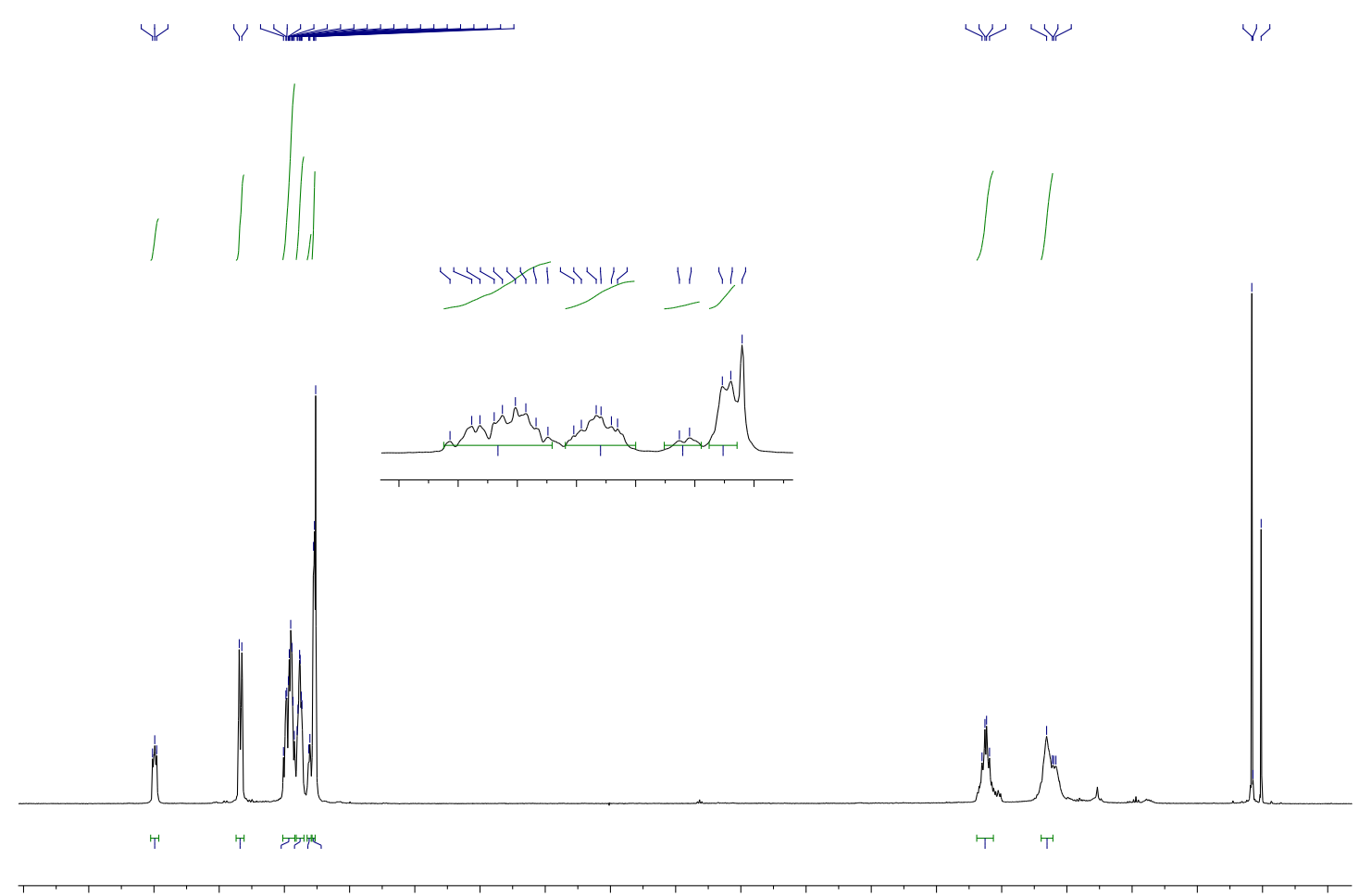

$\begin{array}{lllllll}\text { Figure } & \text { S169: } & { }^{13} \mathrm{C} & \text { NMR } & (101 & \mathrm{MHz}, & \text { Chloroform- } d)\end{array}$ 1,4-bis(1-naphthalenylphenylphosphaneyl)butane (2aj).

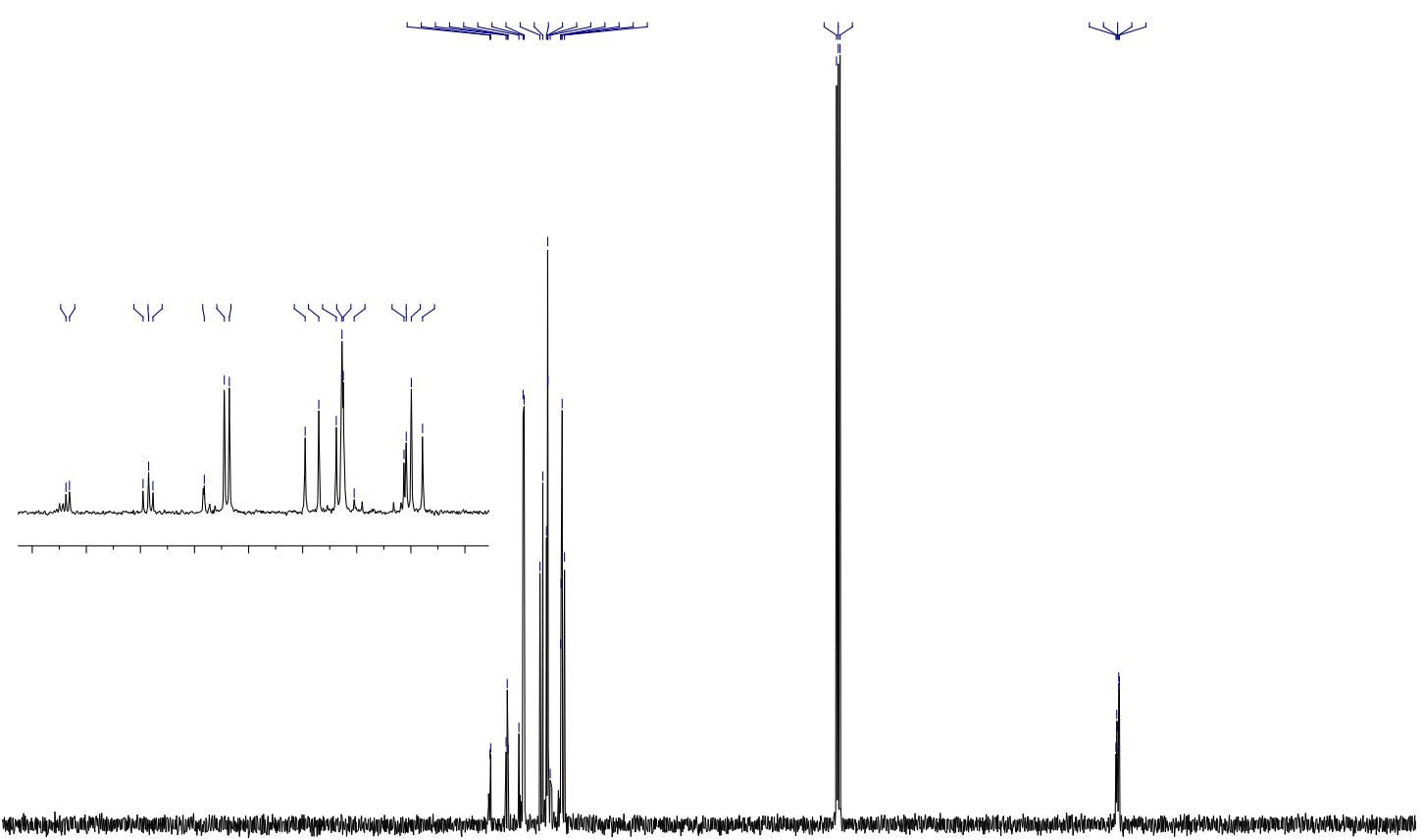


Figure S170: ${ }^{31} \mathrm{P}$ NMR (162 MHz, Chloroform-d) for 1-naphthyln-butylphenylphosphane (2al).

Figure S171: ${ }^{1} \mathrm{H}$ NMR (400 MHz, Chloroform-d) for 1-naphthyln-butylphenylphosphane (2al).

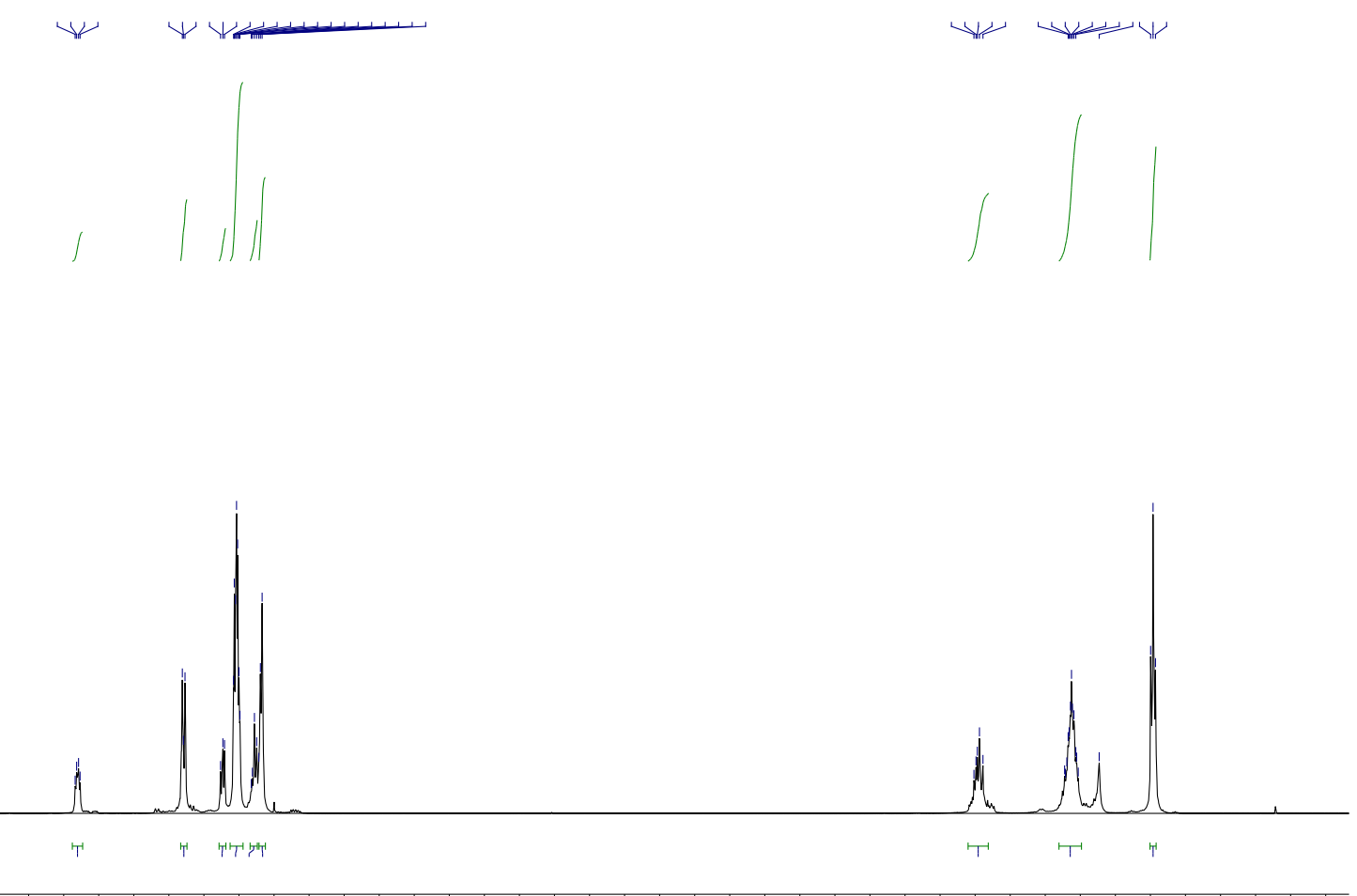


Figure S172: ${ }^{13} \mathrm{C}$ NMR (101 MHz, Chloroform-d) for 1-naphthyln-butylphenylphosphane (2al).
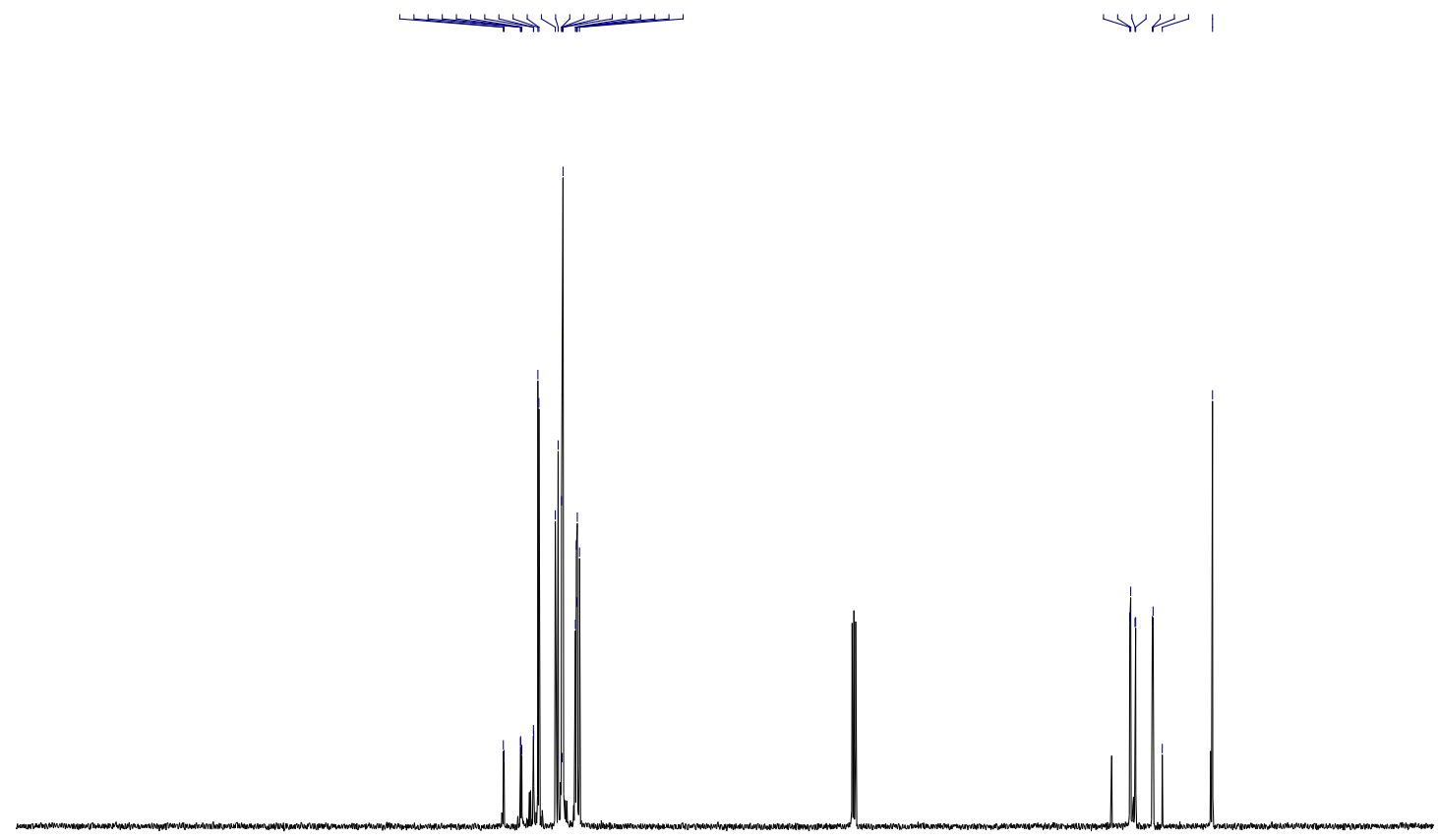

Figure S173: ${ }^{31} \mathrm{P}$ NMR (162 MHz, Chloroform- $d$ ) for (+)-neomenthyldiphenylphosphine (NMDPP) 
Figure S174: ${ }^{1} \mathrm{H}$ NMR analysis (400 MHz, Chloroform-d) for (+)-neomenthyldiphenylphosphine (NMDPP)

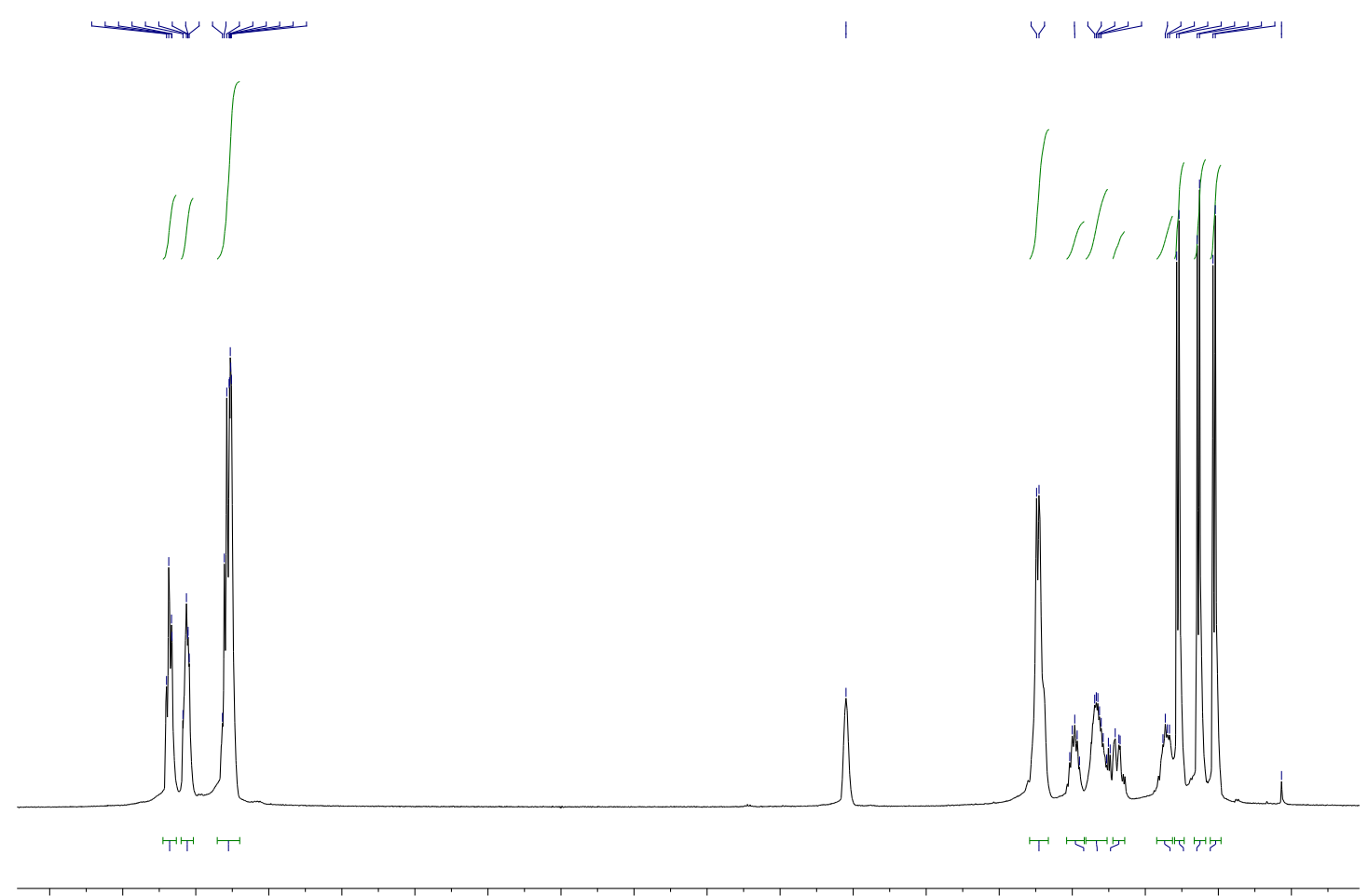

Figure S175: ${ }^{31} \mathrm{P}$ NMR (162 MHz, Chloroform-d) for (-)-menthyldiphenylphosphine oxide.

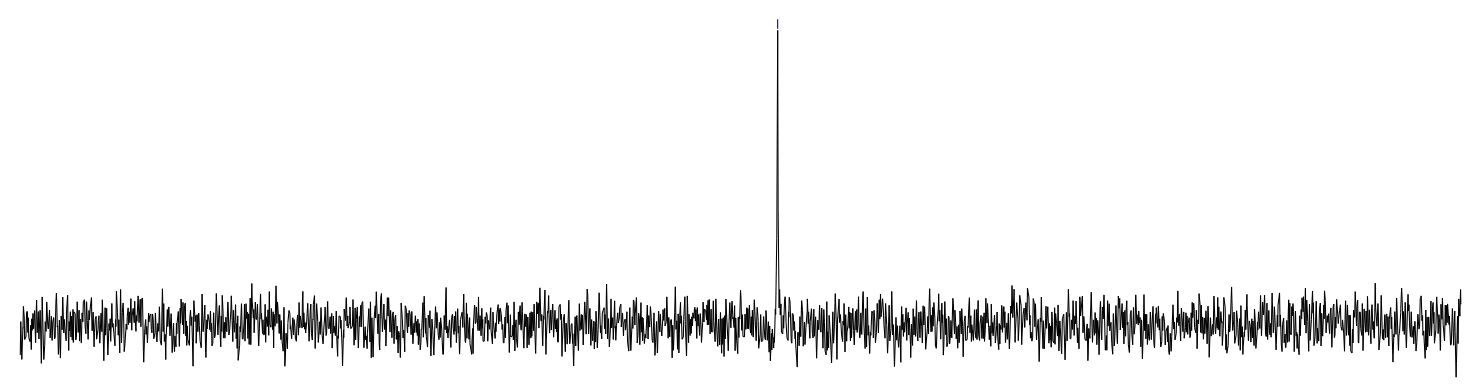


Figure S176: ${ }^{1} \mathrm{H}$ NMR (400 MHz, Chloroform- $d$ ) for (-)-menthyldiphenylphosphine oxide.

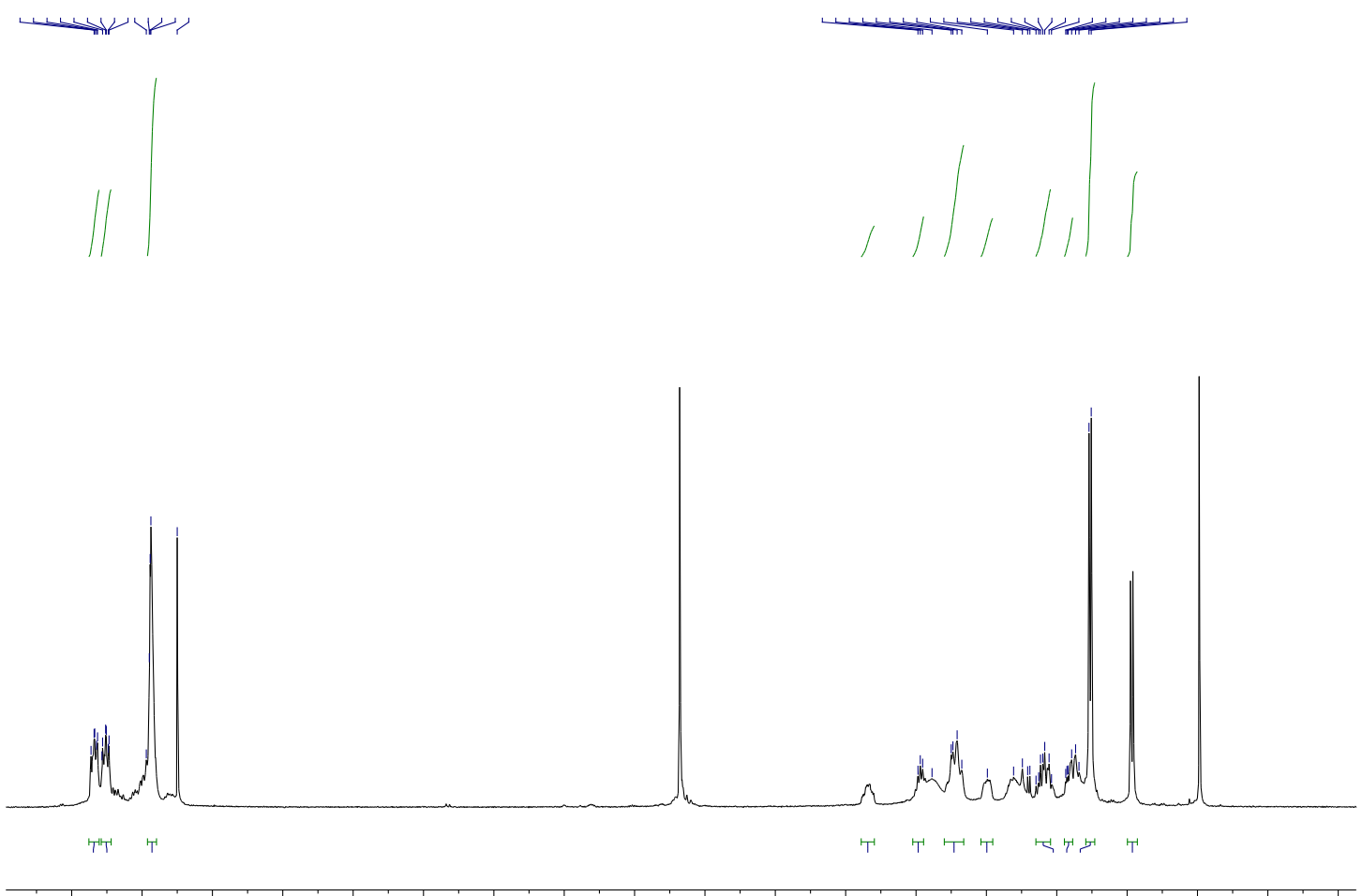

